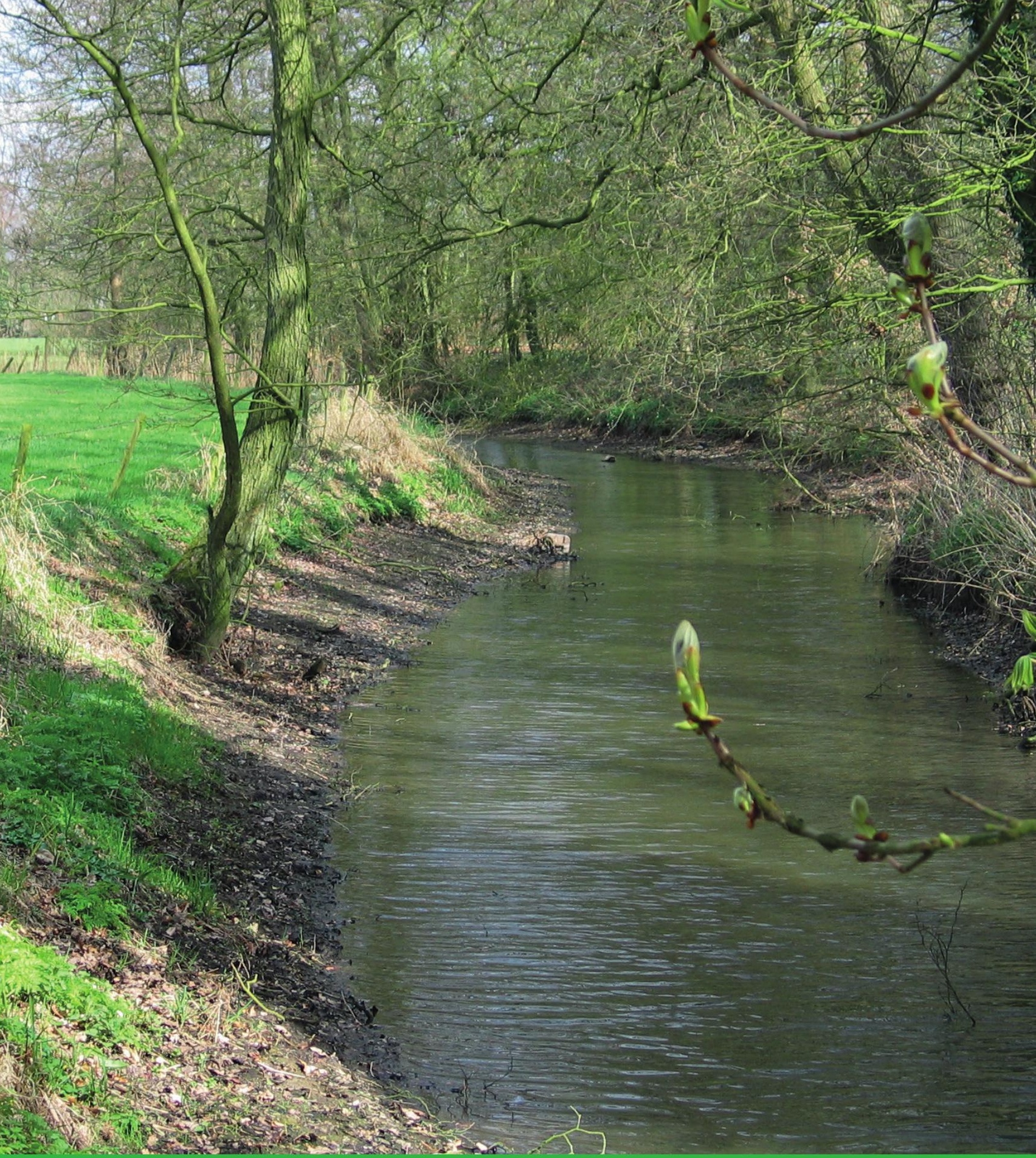

\title{
Landbouw en waterkwaliteit
}

Gerard Velthof en Piet Groenendijk

WAGENINGEN

UNIVERSITY \& RESEARCH 



\section{Landbouw en waterkwaliteit}

Gerard Velthof en Piet Groenendijk

Dit onderzoek is uitgevoerd door Wageningen Environmental Research in opdracht van en gefinancierd door het ministerie van Landbouw, Natuur en Voedselkwaliteit, in het kader van het Beleidsondersteunend onderzoekthema 'Mest, milieu en klimaat (projectnummer BO-43-012.02-084).

Wageningen Environmental Research

Wageningen, maart 2021

Gereviewd door:

dr. H.P Broers (TNO), dr. J. Rozemeijer (Deltares), dr. W. Bussink (NMI) en ir. B. Fraters (RIVM)

Akkoord voor publicatie:

G.J. Reinds, teamleider van Duurzaam Bodemgebruik

Rapport 3070

ISSN 1566-7197 
Velthof, G.L. en P. Groenendijk, 2021. Landbouw en waterkwaliteit. Wageningen, Wageningen Environmental Research, Rapport 3070. 92 blz.; 51 fig.; 14 tab.; 97 ref.

Het gebruik van nutriënten in de landbouw heeft effect op de kwaliteit van grond- en oppervlaktewater. De landen uit de Europese Unie moeten voldoen aan de waterkwaliteitseisen uit de Nitraatrichtlijn en Kaderrichtlijn Water. Er is een analyse uitgevoerd van de ontwikkelingen in landbouw en waterkwaliteit. De opbrengsten van gewassen fluctueren de laatste jaren door effecten van droogte, na een periode van meer dan tien jaar met een stijgende trend voor de meeste gewassen. De stikstofoverschotten op de bodembalans van bedrijven zijn sinds 2010 niet sterk veranderd. De nitraatconcentratie in het water dat uitspoelt uit de wortelzone op landbouwbedrijven in de zand-, veen-, löss- en kleiregio's, laat langjarig een dalende trend zien. Melkveebedrijven voldoen gemiddeld aan de nitraatnorm, maar de nitraatnorm is gemiddeld nog niet gerealiseerd op akkerbouwbedrijven in de zandregio. De nitraatconcentraties zijn in alle regio's sterk gestegen door droogte in 2018. In de meeste stroomgebieden is sprake van een daling van stikstof- en fosforconcentraties in het oppervlaktewater. De maatregelen uit het Vijfde en Zesde Actieprogramma van de Nitraatrichtlijn en de maatregelen uit het Deltaplan Agrarisch Waterbeheer (DAW) zullen waarschijnlijk niet tot realisatie van de waterkwaliteitsdoelstellingen leiden. In veel gebieden zijn extra maatregelen nodig. De herziening van het mestbeleid en de maatregelen in het kader van het ammoniak- en klimaatbeleid zullen in de toekomst een effect hebben op nutriëntenuitspoeling uit landbouwgronden. De invulling van dit beleid is echter op dit moment nog onduidelijk.

Trefwoorden: fosfaat, mest, mestbeleid, nitraat, Kaderrichtlijn Water, Nitraatrichtlijn, stikstof, waterkwaliteit

Dit rapport is gratis te downloaden van https://doi.org/10.18174/543893 of op www.wur.nl/environmental-research (ga naar 'Wageningen Environmental Research' in de grijze balk onderaan). Wageningen Environmental Research verstrekt geen gedrukte exemplaren van rapporten.

2021 Wageningen Environmental Research (instituut binnen de rechtspersoon Stichting Wageningen Research), Postbus 47, 6700 AA Wageningen, T 03174807 00, www.wur.nl/environmental-research. Wageningen Environmental Research is onderdeel van Wageningen University \& Research.

- Overname, verveelvoudiging of openbaarmaking van deze uitgave is toegestaan mits met duidelijke bronvermelding.

- Overname, verveelvoudiging of openbaarmaking is niet toegestaan voor commerciële doeleinden en/of geldelijk gewin.

- Overname, verveelvoudiging of openbaarmaking is niet toegestaan voor die gedeelten van deze uitgave waarvan duidelijk is dat de auteursrechten liggen bij derden en/of zijn voorbehouden.

Wageningen Environmental Research aanvaardt geen aansprakelijkheid voor eventuele schade voortvloeiend uit het gebruik van de resultaten van dit onderzoek of de toepassing van de adviezen.

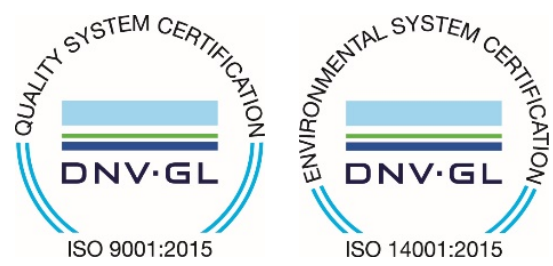

Wageningen Environmental Research werkt sinds 2003 met een ISO 9001 gecertificeerd kwaliteitsmanagementsysteem.

In 2006 heeft Wageningen Environmental Research een milieuzorgsysteem geïmplementeerd, gecertificeerd volgens de norm ISO 14001.

Wageningen Environmental Research geeft via ISO 26000 invulling aan haar maatschappelijke verantwoordelijkheid.

Wageningen Environmental Research Rapport 3070 | ISSN 1566-7197

Foto omslag: Gerard Velthof 


\section{Inhoud}

Verantwoording $\quad 5$

$\begin{array}{ll}\text { Samenvatting } & 7\end{array}$

1

Inleiding

11

2

Implementatie van maatregelen uit het mestbeleid $\quad 13$

2.1 Mest en ammoniakbeleid 13

2.2 Maatregelen in het Vijfde Actieprogramma Nitraatrichtlijn (2014-2017) 14

2.3 Maatregelen in het Zesde Actieprogramma Nitraatrichtlijn (2018-2021) 14

2.4 Derogatie 15

2.5 Samenvatting $\quad 16$

3

$\begin{array}{ll}\text { Het weer } & 17\end{array}$

3.1 Effecten van het weer op stikstof- en fosfaatuitspoeling en waterkwaliteit 17

3.2 Trends in temperatuur en neerslag 19

$\begin{array}{lll}3.3 & \text { Samenvatting } & 22\end{array}$

4 Ontwikkelingen in de landbouw $\quad 23$

$\begin{array}{lll}4.1 & \text { Bedrijven } & 23\end{array}$

$\begin{array}{lll}4.2 & \text { Gewassen } & 23\end{array}$

4.2.1 Uitspoelingsgevoeligheid van gewassen 23

$\begin{array}{ll}4.2 .2 \text { Arealen } & 24\end{array}$

4.2.3 Opbrengsten $\quad 25$

$\begin{array}{lll}4.3 & \text { Veestapel } & 28\end{array}$

4.3.1 Dieraantallen $\quad 28$

$\begin{array}{ll}\text { 4.3.2 Melkproductie } & 28\end{array}$

$\begin{array}{ll}4.3 .3 \text { Beweiding } & 28\end{array}$

4.4 Ammoniakmaatregelen $\quad 29$

4.5 Samenvatting $\quad 30$

$5 \quad$ Trends in mestproductie en gebruik van meststoffen 32

5.1 Mestproductie $\quad 32$

5.2 Ontwikkeling mestmarkt en mestverwerking 33

5.2.1 Afzet buiten de Nederlandse landbouw 33

5.2.2 Mestafzetprijzen 36

$\begin{array}{lll}5.3 & \text { Meststoffengebruik } & 37\end{array}$

$\begin{array}{ll}\text { 5.3.1 Melkveebedrijven } & 37\end{array}$

5.3.2 Akkerbouwbedrijven $\quad 40$

$\begin{array}{ll}5.3 .3 \text { Overbemesting } & 42\end{array}$

$\begin{array}{lll}5.4 & \text { Samenvatting } & 44\end{array}$

$6 \quad$ Stikstof- en fosfaatbalansen van de Nederlandse landbouw 45

6.1 Stikstof- en fosfaatbalansen van cultuurgrond $\quad 45$

6.2 Stikstof- en fosfaatbalansen van de melkveehouderij en de akkerbouw $\quad 45$

$\begin{array}{lll}6.3 & \text { Samenvatting } & 48\end{array}$ 
$\begin{array}{lll}7.1 & \text { Inleiding } & 49\end{array}$

$\begin{array}{lll}7.2 & \text { Gehalte aan organische stof } & 49\end{array}$

$\begin{array}{lll}7.3 & \text { Beschikbaarheid van nutriënten } & 50\end{array}$

$\begin{array}{lll}\text { 7.3.1 Stikstof } & 50\end{array}$

$\begin{array}{ll}\text { 7.3.2 Fosfor } & 51\end{array}$

7.3.3 Kalium en magnesium $\quad 51$

$\begin{array}{lll}7.4 & \text { Zuurgraad }(\mathrm{pH}) & 52\end{array}$

$\begin{array}{lll}7.5 & \text { Bodemverdichting } & 53\end{array}$

$\begin{array}{lll}7.6 & \text { Bodemleven } & 54\end{array}$

$\begin{array}{lll}7.7 & \text { Samenvatting } & 56\end{array}$

$\begin{array}{lll}8.1 & \text { Monitoring van waterkwaliteit } & 57\end{array}$

8.2 Nitraatconcentratie in het water dat uit de wortelzone spoelt 57

$\begin{array}{lll}8.3 & \text { Nitraatconcentratie in het diepere grondwater } & 61\end{array}$

8.4 Stikstof- en fosforconcentraties in het oppervlaktewater 63

8.4.1 Normen voor het oppervlaktewater $\quad 63$

8.4.2 Nitraatconcentratie in het oppervlaktewater 63

8.4.3 Stikstof- en fosforconcentraties in oppervlaktewater 65

$\begin{array}{lll}8.5 & \text { Grondwaterbeschermingsgebieden } & 69\end{array}$

$\begin{array}{lll}8.6 & \text { Biologische kwaliteit } & 70\end{array}$

$\begin{array}{lll}8.7 & \text { Samenvatting } & 71\end{array}$

$\begin{array}{ll}\text { Synthese } & 72\end{array}$

9.1 Trends in waterkwaliteit $\quad 72$

$\begin{array}{lll}9.2 & \text { Effecten van het weer op de waterkwaliteit } & 73\end{array}$

9.3 Effecten van maatregelen uit het mestbeleid op landbouw en
waterkwaliteit

9.3.1 Maatregelen Vijfde Actieprogramma Nitraatrichtlijn $\quad 74$

9.3.2 Maatregelen Zesde Actieprogramma Nitraatrichtlijn $\quad 75$

$\begin{array}{ll}\text { 9.3.3 Deltaplan Agrarisch Waterbeheer } & 78\end{array}$

$\begin{array}{ll}\text { 9.3.4 Derogatie } & 78\end{array}$

9.4 Effecten van andere factoren op de waterkwaliteit $\quad 79$

$\begin{array}{lll}9.5 & \text { Vooruitblik } & 80\end{array}$

9.5.1 Ontwikkeling van de waterkwaliteit in de toekomst $\quad 80$

9.5.2 Deltaplan Agrarisch Waterbeheer $\quad 80$

9.5.3 Grondwaterbeschermingsgebieden $\quad 81$

9.5.4 Aanvullende maatregelen om uitspoeling van nutriënten te
beperken

9.5.5 Contouren nieuw mestbeleid $\quad 82$

9.5.6 Andere beleidsthema's 83

9.6 Conclusies $\quad 84$

$\begin{array}{ll}\text { Literatuur } & 86\end{array}$ 


\section{Verantwoording}

Rapport: 3070

Projectnummer: 5200046932

Wageningen Environmental Research (WENR) hecht grote waarde aan de kwaliteit van zijn eindproducten. Een review van de rapporten op wetenschappelijke kwaliteit door een referent maakt standaard onderdeel uit van ons kwaliteitsbeleid.

Akkoord teamleider voor de inhoud,

naam: $\quad$ Gert Jan Reinds

datum: $\quad$ 17-02-2021 


\section{Samenvatting}

Het gebruik van nutriënten in de landbouw heeft effect op de kwaliteit van grond- en oppervlaktewater. De landen uit de Europese Unie moeten voldoen aan de waterkwaliteitseisen uit de Nitraatrichtlijn en Kaderrichtlijn Water (KRW). De Nitraatrichtlijn heeft als doel de uitspoeling van nitraat uit de landbouw naar grond- en oppervlaktewater en eutrofiëring van oppervlaktewater te verminderen. Een belangrijk doel van de Kaderrichtlijn Water is het realiseren van een goede chemische toestand en, voor sterk veranderde wateren ${ }^{1}$, goed ecologisch potentieel van landoppervlaktewater, overgangswater, kustwateren en grondwater. Het ministerie van LNV heeft aan Wageningen Environmental Research gevraagd om een analyse uit te voeren van de ontwikkelingen in landbouw en waterkwaliteit op basis van de resultaten uit beschikbare rapportages, zoals de rapportage over de Nitraatrichtlijn 2016-2019. De onderhavige studie zal gebruikt worden als een van de studies voor de onderbouwing van maatregelen die vanaf 2022 genomen moeten worden in het Zevende Actieprogramma Nitraatrichtlijn en de derde generatie stroomgebiedbeheerplannen.

De belangrijkste instrumenten uit het mest- en ammoniakbeleid zijn het gebruiksnormenstelsel, voorschriften ter beperking van nutriëntenuitspoeling, voorschriften ter beperking van ammoniakemissies, productierechten ter beperking van productie van dierlijke mest, verantwoorde mestafzet en verplichte mestverwerking en een regeling voor de samenstelling van meststoffen. In actieprogramma's voor de Nitraatrichtlijn worden elke vier jaar maatregelen opgenomen om uitspoeling van stikstof en fosfor vanuit de landbouw naar grond- en oppervlaktewater te beperken.

De totale mestproductie uitgedrukt in stikstof is toegenomen in de periode 2012-2017 door de toename van het aantal koeien en een toename van de stikstofexcretie per koe. In 2018 en 2019 is de totale stikstofproductie iets gedaald door een daling van het aantal koeien. De totale stikstofproductie in mest is in 2019 gelijk aan die van 2010. De fosfaatproductie is gestegen in de periode 2012-2015 door de toename van het aantal koeien en is daarna afgenomen door een daling van het aantal koeien en daling/stabilisatie van de fosfaatexcretie per dier. Op fosfaat is via het voerspoor de laatste jaren sterk gestuurd in verband met overschrijding van het fosfaatplafond en invoering van fosfaatrechten in de melkveesector. De fosfaatproductie in 2019 is 13\% lager dan in 2010. In 2017 is het stikstofplafond overschreden. Het fosfaatplafond is in 2010, 2015 en 2016 overschreden.

Er zijn de laatste tien jaar geen grote veranderingen in arealen van gewassen opgetreden die tot veranderingen in waterkwaliteit kunnen hebben geleid. De opbrengsten van akkerbouwgewassen fluctueren de laatste jaren door effecten van droogte, na een periode van meer dan tien jaar met een stijgende trend voor de meeste gewassen. De stikstofoverschotten op de bodembalans van bedrijven uit het Landelijk Meetnet Effecten Mestbeleid (LMM) zijn sinds 2010 niet sterk veranderd. De laatste jaren is er sprake van fluctuatie in overschotten door effecten van het weer op opbrengsten. In het droge jaar 2018 zijn de stikstof- en fosfaatoverschotten in de meeste grondsoortregio's omhooggegaan door de lagere opbrengsten en de daarmee samenhangende lagere nutriëntenopname.

De nitraatconcentratie in het water dat uitspoelt uit de wortelzone op landbouwbedrijven op zand-, veen-, löss- en kleiregio's, laat langjarig een dalende trend zien. De nitraatconcentratie in het zuidelijke zandgebied (gemiddeld zo'n $75 \mathrm{mg}$ nitraat per $\mathrm{L}$ ) is hoger dan in de zandgebieden midden en noord (variërend tussen $30-50 \mathrm{mg}$ nitraat per $\mathrm{L}$ ). De verschillen in nitraatconcentratie tussen de drie zandgebieden zijn voor een groot deel te verklaren uit de verdeling van de grondwatertrappen en grondsoorten die er voorkomen. In het zuidelijke zandgebied zijn relatief meer uitspoelingsgevoelige zandgronden en het aandeel grasland is lager dan in de andere zandgebieden. Op melkveebedrijven werd gemiddeld voldaan aan de nitraatnorm van $50 \mathrm{mg}$ nitraat per L. De nitraatconcentratie op akkerbouwbedrijven in de zandregio laat een dalende trend zien, maar gemiddeld is de nitraatnorm nog niet gerealiseerd. De nitraatconcentraties zijn in 2018 en 2019 in alle regio's sterk gestegen door droogte.

\footnotetext{
1 Water dat van natuurlijke oorsprong is, maar in hoge mate door mensen is veranderd.
} 
De verschillen in weer tussen jaren zijn groot. In de jaren 2017, 2018, 2019 en 2020 kwamen droge perioden voor, vaak gevolgd door een natte periode. De jaargemiddelde temperatuur in Nederland is trendmatig en statistisch significant toegenomen. Ook perioden met zware neerslag in Nederland zijn sterk toegenomen in de laatste decennia. De hoeveelheid neerslag en de temperatuur kunnen via verschillende mechanismen in de bodem een effect hebben op de kwaliteit van grondwater en oppervlaktewater, namelijk i) via factoren (zoals de opbrengst) die leiden tot een hoger of lager stikstof- en/of fosfaatoverschot, ii) verdunnings-/indikkingseffecten door de hoeveelheid uitspoelend water, iii) biologische processen in de bodem en sloot en iv) transportroutes van stikstof en fosfaat in de bodem naar grond- en oppervlaktewater. Mochten perioden van extreme droogte en natte perioden in de toekomst vaker voorkomen door klimaatverandering, dan wordt het lastig om de effectiviteit van maatregelen op de waterkwaliteit over een korte periode van enkele jaren te bepalen. De verwachte effecten van de maatregelen om uitspoeling te beperken, zijn namelijk kleiner dan de grote fluctuaties in waterkwaliteit in de recente droge jaren. Dit vraagt om een nadere beschouwing van de monitoring van waterkwaliteit en de evaluatie van de monitoringsresultaten. Gebruik van modellen om de nitraatconcentraties te corrigeren voor weer kunnen hierbij bruikbaar zijn. Ook zullen er maatregelen genomen moeten worden om de negatieve effecten van droge en natte perioden op de waterkwaliteit te voorkomen.

De stikstofconcentratie (zomergemiddelde) in landbouw specifiek oppervlaktewater (MNLSO) laat een langjarig dalende trend zien. De concentraties waren relatief laag in de droge zomer van 2018 (minder uitspoeling, meer retentie), maar er was sprake van zeer hoge stikstofconcentratie vanaf december 2018 tot maart 2019. De fosforconcentraties fluctueren sterk in de tijd, maar langjarig is er sprake van een dalende trend. Alleen de fosforconcentraties in de stroomgebieden van de Schelde en Maas laten een opwaartse trend laten zien. Het percentage locaties in het landbouw specifiek oppervlaktewater dat aan waterschapsnormen ${ }^{2}$ voldoet, varieert voor stikstof tussen $36 \%$ in 2016 en $49 \%$ in 2018 en voor fosfor tussen $49 \%$ in 2016 en 55\% in 2018. Bij fosforconcentratie zijn grote fluctuaties in de tijd zichtbaar in recente jaren. In veel gebieden is nog een extra inspanning nodig om de normen voor stikstof en fosfor in oppervlaktewater te realiseren.

In het Vijfde Actieprogramma Nitraatrichtlijn zijn verschillende maatregelen genomen waarvan verwacht mag worden dat ze leiden tot minder uitspoeling van stikstof en fosfaat naar grond- en oppervlaktewater. Dit geldt met name voor de verlaging van de stikstofgebruiksnormen voor uitspoelingsgevoelige gewassen in het zuidelijk zand- en lössgebied en verlaging van de derogatie voor bemesting met graasdierenmest in de zandgebieden Zuid en Midden en de lössregio. Op basis van resultaten van LMM lijken de maatregelen uit het Vijfde Actieprogramma tot een vermindering van de nitraatuitspoeling op akkerbouwbedrijven op zandgrond te hebben geleid in 2017, maar monitoring over een langere periode is nodig om hierover hardere uitspraken te doen.

De effecten van de meeste maatregelen uit het Zesde Actieprogramma Nitraatrichtlijn zijn nog niet duidelijk, omdat ze in 2020 en 2021 zijn/worden geïmplementeerd. Van de maatregelen die 1 januari 2019 zijn ingegaan, is een deel gericht op verruimingen in landbouwkundig handelen, maar niet op verbeteren van waterkwaliteit. De strengere eisen aan zaaien van het vanggewas na snijmaïs zullen waarschijnlijk de komende jaren tot een verlaging van de nitraatuitspoeling leiden. Van de andere maatregelen uit het Zesde Actieprogramma Nitraatrichtlijn wordt een beperkt effect verwacht op de landelijke gemiddelde nitraatconcentratie in het grondwater, onvoldoende om gebiedsgemiddeld ook in het zuidelijke zand- en lössgebied aan de nitraatnorm te voldoen. Ook worden er geringe effecten op de stikstof- en fosfaatbelasting van het oppervlaktewater verwacht bij de maatregelen uit het Zesde Actieprogramma.

De plaatsingsruimte voor dierlijke mest, zowel uitgedrukt in stikstof als fosfaat, is in de periode 20102019 afgenomen door aanscherpingen in de gebruiksnormen. De export en mestverwerking zijn in deze periode toegenomen. Berekeningen op basis van de stikstof- en fosfaatgebruiksruimte en de export van mest geven aan dat er in Nederland meer bemest wordt dan volgens de gebruiksnormen is

\footnotetext{
2 Voor de kleinere wateren die niet als KRW-waterlichaam zijn aangewezen en die ook wel 'overige wateren' worden genoemd, is een methodiek ontwikkeld die is afgeleid van de KRW-systematiek voor de KRW-waterlichamen (Buijs et al., 2020). Deze methodieken zijn door de waterbeheerders gebruikt voor het afleiden van de nutriëntennormen voor de MNSLO-meetlocaties die niet in een KRW waterlichaam liggen ('waterschapsnormen').
} 
toegestaan (overbemesting). De onzekerheden in de berekening van mestplaatsing zijn echter groot. Het is niet duidelijk op welke schaal en waar overbemesting plaatsvindt. Wel is duidelijk dat overbemesting het bodemoverschot vergroot en daarmee mogelijk mede een oorzaak kan zijn van het niet realiseren van de waterkwaliteitsdoelstellingen. Het is nog niet duidelijk wat de effecten op waterkwaliteit zijn van de versterkte handhavingsstrategie mest.

Bodemverdichting komt op grote schaal voor in Nederland en heeft waarschijnlijk een effect op de uitspoeling van stikstof en fosfaat naar grond- en oppervlaktewater. Het is echter niet bekend welke rol bodemverdichting speelt bij de belasting van grond- en oppervlaktewater met nutriënten en of hierin de laatste tien jaar veranderingen zijn optreden. De langjarige trend in het gehalte aan organische stof in landbouwgronden is stabiel tot licht stijgend en er is geen reden om aan te nemen dat het gehalte aan organische stof heeft geleid tot veranderingen in waterkwaliteit. Er is ook geen aanleiding om te veronderstellen dat veranderingen in bodembiodiversiteit gedurende de laatste tien jaar hebben geleid tot veranderingen in waterkwaliteit.

Modelberekeningen geven aan dat de maatregelen uit het Vijfde en Zesde Actieprogramma en de maatregelen uit Deltaplan Agrarisch Waterbeheer (DAW) waarschijnlijk niet tot de realisatie van de nitraatdoelstellingen zullen leiden. Voor een deel van de wateren zijn verdergaande maatregelen nodig. Het realiseren van de doelstellingen uit de 'Bestuursovereenkomst aanvullende aanpak nitraatuitspoeling uit agrarische bedrijfsvoering in specifieke grondwaterbeschermingsgebieden' zal voor een groot deel van de gebieden lastig zijn. Naast strikte maatregelen over nutriëntenbeheer op bedrijven zullen andersoortige maatregelen moeten worden genomen om in grondwaterbeschermingsgebieden te voldoen aan de nitraatnorm.

De herziening van het mestbeleid en de maatregelen in het kader van het ammoniak- en klimaatbeleid zullen in de toekomst een effect hebben op nutriëntengebruik en daarmee nitraat- en fosfaatuitspoeling uit landbouwgronden. De invulling van dit beleid is echter op dit moment nog onduidelijk. Er wordt verwacht dat dit beleid geen grote bijdrage zal leveren aan het realiseren van waterkwaliteitsdoelstellingen op korte termijn, dat wil zeggen gedurende het Zevende Actieprogramma Nitraatrichtlijn (2022-2026) en derde generatie stroomgebiedbeheerplannen van de Kaderrichtlijn Water (2021-2027).

Er is een groot aantal maatregelen op het gebied van gewaskeuze, gewas- en bodembeheer, hydrologie, technische maatregelen en ruimtelijke maatregelen, die tot een verbetering van de waterkwaliteit kunnen leiden. De toepassing, effectiviteit en de termijn waarop effecten van maatregelen op de waterkwaliteit zichtbaar zijn, is sterk afhankelijk van regionale omstandigheden. Naar verwachting zijn ook structurele aanpassingen in de landbouw nodig om overal te voldoen aan de waterkwaliteitsnormen, zoals het aanpassen van gewassen in het bouwplan op uitspoelingsgevoelige gronden. 


\section{$1 \quad$ Inleiding}

Het gebruik van nutriënten in de landbouw heeft effect op de kwaliteit van grond- en oppervlaktewater. De landen uit de Europese Unie moeten voldoen aan de eisen uit de Nitraatrichtlijn (EU, 1991) en Kaderrichtlijn Water (KRW; EU, 2000) om waterkwaliteit te verbeteren.

De Nitraatrichtlijn heeft als doel de uitspoeling van nitraat uit de landbouw naar grond- en oppervlaktewater en eutrofiëring van oppervlaktewater te verminderen. Nederland rapporteert elke vier jaar de ontwikkelingen in waterkwaliteit en landbouw aan de Europese Commissie in het kader van de Nitraat-richtlijn. In deze Nitraatrichtlijnrapportage worden trends gegeven van nitraat-, stikstof- en fosfor-concentraties in grond- en oppervlaktewater en landbouwkundige indicatoren, zoals mestproductie, bemesting en stikstof- en fosfaatoverschotten. Recentelijk is de zevende landenrapportage gepubliceerd, die betrekking heeft op de periode van 20 december 2014 tot 20 december 2019 (Fraters et al., 2020). De resultaten worden gebruikt voor het opstellen van het Zevende Actieprogramma van de Nitraatrichtlijn (periode 2022 t/m 2025). In een Actieprogramma worden de maatregelen in de landbouw opgenomen waarmee voldaan moet worden aan de doelstellingen uit de Nitraatrichtlijn. Deze maatregelen, bestaande uit bemestingsnormen en middelvoorschriften, zijn grotendeels opgenomen in de Meststoffenwet.

Het doel van de Kaderrichtlijn Water is het realiseren van een goede chemische toestand en goed ecologisch potentieel van landoppervlaktewater, overgangswater, kustwateren en grondwater. In de Kaderrichtlijn Water zijn normen vastgesteld voor een groot aantal stoffen, waaronder nutriënten. De Kaderrichtlijn Water integreert verschillende richtlijnen, zoals de Nitraatrichtlijn en Grondwaterrichtlijn. Recentelijk is de nationale analyse waterkwaliteit (Van Gaalen et al., 2020) uitgevoerd, die gebruikt zal worden voor het samenstellen van de maatregelpakketten voor de derde generatie stroomgebiedbeheerplannen (periode 2022 t/m 2027) om de doelen uit de Kaderrichtlijn Water te realiseren.

Het ministerie van LNV heeft aan Wageningen Environmental Research gevraagd om een analyse uit te voeren van de ontwikkelingen in landbouw en waterkwaliteit op basis van de resultaten uit het Nitraatrichtlijnrapport van Fraters et al., (2020) en andere beschikbare bronnen van informatie, zoals de nationale analyse waterkwaliteit van Van Gaalen et al. (2020), CBS-statline, Agrimatie en adviezen van de Commissie Deskundigen Meststoffenwet (CDM). Het doel van deze studie is om duiding te geven aan ontwikkelingen in de landbouw, de effectiviteit van de maatregelen uit de Meststoffenwet en de invloed van andere factoren (zoals klimaat) op de stikstof- en fosfaatbelasting van grond- en oppervlaktewater en de waterkwaliteit. Deze studie zal gebruikt worden als een van de studies voor de onderbouwing van maatregelen die vanaf 2022 genomen moeten worden in het Zevende Actieprogramma Nitraatrichtlijn en de derde generatie stroomgebiedbeheerplannen.

In dit rapport zullen de meeste trends vanaf begin jaren negentig van de vorige eeuw worden gepresenteerd (conform het rapport voor de Nitraatrichtlijn), maar in de analyses zal het accent worden gelegd op de recentere jaren (vanaf 2010). De duiding zal indien mogelijk kwantitatief worden onderbouwd, maar voor de meeste resultaten zal alleen een kwalitatieve verklaring worden gegeven. Er zijn geen aanvullende statistische analyses (bv. trendanalyses) of modelberekeningen uitgevoerd.

In het mestbeleid worden maatregelen genomen om stikstof- en fosfaatuitspoeling te beperken. In Hoofdstuk 2 wordt een overzicht gegeven van maatregelen uit het mestbeleid, met focus op de recentelijk genomen maatregelen uit het Zesde Actieprogramma Nitraatrichtlijn. Er zal ook kort worden ingegaan op maatregelen uit het Vijfde Actieprogramma Nitraatrichtlijn, omdat maatregelen mogelijk pas na enkele jaren leiden tot veranderingen in de waterkwaliteit.

De laatste jaren zijn gekend door droge perioden, soms afgewisseld door perioden met veel neerslag. Aangezien het weer een groot effect heeft op de groei van gewassen, omzettingen van nutriënten in 
de bodem en uitspoeling, wordt in Hoofdstuk 3 een beschrijving gegeven van trends in klimaat en het weer in recente jaren en hoe dat de nutriëntenuitspoeling beïnvloedt.

In Hoofdstuk 4 wordt een beschrijving gegeven van ontwikkelingen in de landbouw, zoals opbrengsten van gewassen en aantallen landbouwdieren. Hoofdstuk 5 gaat over trends in mestproductie, gebruik van meststoffen en ontwikkelingen in de mestmarkt en mestverwerking. Op basis van de gegevens uit Hoofdstuk 4 en 5 worden in Hoofdstuk 6 stikstof- en fosfaatbalansen van de Nederlandse landbouw gegeven.

Bodemkwaliteit kan een groot effect hebben op de uitspoeling van stikstof en fosfaat naar grond- en oppervlaktewater. Hoofdstuk 7 gaat in op ontwikkelingen in de kwaliteit van landbouwbodems. Hoofdstuk 8 presenteert de trends van de kwaliteit van grond- en oppervlaktewater.

In het synthese Hoofdstuk 9 wordt een analyse gemaakt van de factoren die een effect gehad (kunnen) hebben op de waterkwaliteit, waarbij ingegaan wordt op effecten van het weer, effecten van bodemkwaliteit en effecten van ontwikkelingen in de landbouw. Bij de ontwikkelingen in de landbouw wordt onderscheid gemaakt tussen effecten van maatregelen uit het mestbeleid en effecten van andere ontwikkelingen.

Het rapport is gereviewd door dr. H.P Broers (TNO), dr. J. Rozemeijer (Deltares), dr. D.W. Bussink (NMI) en ir. B. Fraters (RIVM). Naar de reviewers en het ministerie van LNV is teruggekoppeld hoe de reviews zijn verwerkt. 


\section{Implementatie van maatregelen uit het mestbeleid}

\subsection{Mest en ammoniakbeleid}

Het mest- en ammoniakbeleid in Nederland beoogt de belasting van bodem, grondwater en oppervlaktewater met stikstof en fosfaat uit de landbouw en de emissies van ammoniak naar de atmosfeer te beperken, zodat wordt voldaan aan de gestelde doelen:

- Nitraatconcentratie in grondwater en oppervlaktewater minder dan $50 \mathrm{mg}$ nitraat $\left(\mathrm{NO}_{3}{ }^{-}\right)$per $\mathrm{L}$ (conform Nitraatrichtlijn en Grondwaterrichtlijn);

- Beperking van eutrofiëring van oppervlaktewater (conform Nitraatrichtlijn) en bijdragen aan het realiseren van een goede ecologische toestand van oppervlaktewater, met stikstof- en fosforconcentratie die voldoen aan de ecologisch doelen gesteld per watertype, conform KRW;

- Totale ammoniakemissie (inclusief niet-landbouw) minder dan ammoniakplafonds uit de NECrichtlijn voor 2020 en het UNECE-Göteborg Protocol en een emissiebeperking, zodat de stikstofdepositie op Natura2000-gebieden wordt verlaagd en er voldaan kan worden aan de eisen van de Vogel- en Habitatrichtlijn;

- Voorkoming van de verontreiniging van bodem door aanvoer van contaminanten via meststoffen, conform de Wet Bodembescherming en de Meststoffenwet.

Vanaf 1984 zijn verschillende maatregelen ingevoerd. Veel maatregelen zijn in de voorbije dertig jaar aangepast, aangescherpt of vervangen. De belangrijkste instrumenten (stelsels, cluster van maatregelen) uit het mest- en ammoniakbeleid zijn momenteel (CDM, 2016):

1. Gebruiksnormenstelsel (Nitraatrichtlijn; Kaderrichtlijn Water):

- Gebruiksnormen voor stikstof in dierlijke mest;

- Gewas- (en soms ras-), grondsoort- en opbrengst-afhankelijke gebruiksnormen voor stikstof;

- Fosfaattoestand-afhankelijke gebruiksnormen voor fosfaat voor bouwland en grasland.

2. Voorschriften ter beperking van nutriëntenuitspoeling (Nitraatrichtlijn; Kaderrichtlijn Water):

- Administratie van mest- en meststoffengebruik;

- Minimale mestopslagcapaciteit;

- Beperking uitrijdperioden voor dierlijke mest en kunstmest;

- Beperking toedienen van mest op hellingen, drassige, ondergelopen, besneeuwde of bevroren grond of tijdens irrigatie;

- Verplichting om volggewassen te telen na de oogst van bepaalde eenjarige gewassen;

- Bufferstroken en/of teeltvrije zones langs waterlopen;

- Beperkingen aan scheuren (ploegen, vernieuwen) van grasland;

- Verbod op fosfaatkunstmest voor bedrijven met een derogatie.

3. Voorschriften ter beperking van ammoniakemissies (NEC-richtlijn, UNECE-Gothenborg-protocol, Vogel- en Habitatrichtlijn):

- Emissiearme opslag en toediening van dierlijke mest;

- Emissiearme stalsystemen.

4. Productierechten ter beperking productie van dierlijke mest (Nederlands beleid):

- Fosfaatrechten melkveehouderij;

- Varkensrechten;

- Pluimveerechten.

5. Verantwoorde mestafzet en verplichte mestverwerking (Nederlands beleid):

- Stalbalansen en diergebonden forfaits (inclusief Bedrijf-specifieke Excretie, BEX);

- Transport en traceerbaarheid dierlijke mest; vervoersbewijzen dierlijke mest voor bedrijfsvreemde mest (AGR-GPS) en bemonstering- en analyseprotocollen;

- Verplichte mestverwerking voor bedrijven met mestoverschot;

- Wet Verantwoorde Groei Melkveehouderij en de wet grondgebonden groei;

- Convenant beperking fosfaatgehalten in veevoer (dit is een privaatrechtelijke afspraak).

6. Regeling samenstelling meststoffen (conform EU-fertilizer regulation en NL-beleid) 


\subsection{Maatregelen in het Vijfde Actieprogramma Nitraatrichtlijn (2014-2017)}

Belangrijke maatregelen uit het Vijfde Actieprogramma Nitraatrichtlijn waren:

- De werkingscoëfficiënt van varkensdrijfmest is in 2014 verhoogd van 70 tot $80 \%$ op alle zand- en lössgronden. Hierdoor kan er minder stikstofkunstmest worden toegepast binnen de gebruiksnorm voor werkzame stikstof.

- Vanaf 2014 is de derogatie voor bemesting met graasdierenmest op zand- en lössgronden in de zandgebieden zuid en midden en de lössregio verlaagd van 250 naar $230 \mathrm{~kg} \mathrm{~N}$ per ha. Verder is voor alle grondsoortregio's in Nederland als eis gesteld dat voor een bedrijf met derogatie het areaal minimaal uit $80 \%$ grasland moet bestaan (dit was $70 \%$ ).

- In 2015 zijn de stikstofgebruiksnormen voor uitspoelingsgevoelige gewassen op zand- en lössgronden in het zuidelijk zand- en lössgebied met $20 \%$ verlaagd, waaronder die van aardappelen, suikerbieten en een groot aantal groentegewassen.

- De fosfaatgebruiksnormen zijn verlaagd in 2014 en 2015.

- De stikstofgebruiksnorm voor grasland op klei is verhoogd.

- Er is een opbrengstafhankelijke stikstofgebruiksnorm voor graan op klei ingevoerd.

- Het stelsel van verplichte mestverwerking is ingevoerd.

\subsection{Maatregelen in het Zesde Actieprogramma Nitraatrichtlijn (2018-2021)}

Hieronder worden de belangrijkste maatregelen uit het Zesde Actieprogramma Nitraatrichtlijn weergegeven per ingangsdatum.

Vanaf 2019

- De stikstofgebruiksnorm voor een groenbemester in de periode van 1 augustus tot en met 15 september wordt ook toegepast voor graszaadstoppel.

- De stikstofgebruiksnorm in de graszaadteelt van veldbeemd op kleigrond is verhoogd van 110 naar 130 kg N per ha.

- Er worden strengere eisen gesteld aan een vanggewas na maïs op zand- en lössgrond per

1 januari 2019. Er zijn drie mogelijkheden:

- Onderzaai van gras of ander geschikt vanggewas in het perceel waarop de teelt van snijmaïs plaatsheeft;

- Inzaai van een vanggewas op uiterlijk 1 oktober (aansluitend na de oogst van de maïs);

- Inzaai van enkele specifieke gewassen met een hoge stikstofopname als hoofdteelt na de teelt van snijmaïs, waaronder wintertarwe, in de maand oktober.

- Op grasland gelegen op klei- en veengrond wijzigt de uitrijdperiode van vaste dierlijke mest van 1 februari tot en met 15 september naar 1 december tot en met 15 september (per 1 januari 2019).

- Op bouwland verschuift de uitrijdperiode van drijfmest van 1 februari tot en met 31 augustus naar 15 februari tot en met 15 september (per 1 januari 2019).

- Aanpassing regels vernietigen van grasland (per 1 januari 2019):

- Na 10 mei is het vernietigen van de graszode uitsluitend toegestaan tot uiterlijk 1 september als er aansluitend herinzaai met gras plaatsvindt;

- In het geval van vernietigen van de graszode na 31 mei wordt een korting van $50 \mathrm{~kg}$ stikstof per ha op de stikstofgebruiksnorm toegepast.

Vanaf 2020

- Vanaf 2015 zijn fosfaatgebruiksnormen verlaagd met $5 \mathrm{~kg}$ per ha, met uitzondering van die voor grasland met een lage fosfaattoestand (Tabel 1 ). De indeling van de fosfaatklassen op landbouwgrond is per 1 januari 2020 zodanig aangepast dat de huidige klasse 'neutraal' is gesplitst in een klasse 'neutraal' en een klasse 'ruim voldoende'. De gebruiksnorm voor de klasse 'hoog' is vanaf 2020 verlaagd en die van 'laag' en 'neutraal' zijn verhoogd (Tabel 1). 
- Hogere fosfaatgebruiksnorm in fosfaatklasse 'hoog' bij toepassing van meststoffen die veel organische stof bevatten (Tabel 1).

Vanaf 2021

- Indien maïs wordt geteeld op landbouwgrond waarop daaraan voorafgaand gras is geteeld, dan wordt de stikstofgebruiksnorm voor maïs gekort met $65 \mathrm{~kg}$ per ha per jaar.

- Maatregelen om afspoeling in ruggenteelten op kleigrond en lössgrond te voorkomen, zoals het aanleggen van drempels (per 1 januari 2021).

Twee andere maatregelen uit het Zesde Actieprogramma zijn in mei 2020 door de minister teruggetrokken en vervangen door andere maatregelen (Ministerie van LNV, 2020):

- De maatregel over verplichte rijenbemesting met dierlijke mest in maïs op zand- en lössgronden (per 1 januari 2021) is vervallen, omdat recent onderzoek laat zien dat deze maatregel niet effectief is (Klootwijk en Van Schooten, 2020). Als alternatieve maatregel wordt de eerste datum waarop het is toegestaan drijfmest toe te dienen aan maïs op zand- en lössgronden verschoven van 15 februari naar 1 april. De equivalente maatregel 'rijenbemesting in maïs' zal hierdoor ook vervallen per 1 januari 2021.

- De maatregel over een verplicht vanggewas uiterlijk op 31 oktober na consumptie- en fabrieksaardappelen op zuidelijke zand- en lössgronden (per op 1 januari 2021) is niet ingevoerd, omdat vanuit de sector naar voren werd gebracht dat dit tot praktische problemen kan leiden met aard-appelopslag. Bij de inzaai van een vanggewas worden achtergebleven aardappelen meer ingewerkt (en blijven dus minder boven op de bodem liggen), waardoor ze mogelijk meer beschermd zijn tegen vorst. Aardappelopslag is lastig in volggewassen (extra onkruid) en de vermeerdering van aaltjes gaat door. In plaats van deze maatregel wordt de stikstofgebruiksnorm voor consumptie- en fabrieksaardappelen op zand- en lössgrond die het jaar na het vernietigen van grasland worden geteeld, met $65 \mathrm{~kg} \mathrm{~N}$ per ha gekort.

Naast bovenstaande maatregelen zijn er afspraken gemaakt over extra reductie van nitraatuitspoeling in kwetsbare drinkwaterwinningen op zand- en lössgrond.

Tabel 1 Fosfaatgebruiksnorm in $\mathrm{kg}$ fosfaat (P2O5) per ha in de periode 2006-2020 voor grasland en akkerland per fosfaattoestand van de bodem (Fraters et al., 2020 en Ministerie van LNV, 2017) ${ }^{1}$.

\begin{tabular}{|c|c|c|c|c|c|c|c|c|c|c|}
\hline Gewas & Toestand & 2006 & 2009 & 2010 & 2011 & 2012 & 2013 & 2014 & $2015 / / 19$ & 2020 \\
\hline \multirow[t]{3}{*}{ Grasland } & Laag & 110 & 100 & 100 & 100 & 100 & 100 & 100 & 100 & 105 \\
\hline & Neutraal & 110 & 100 & 95 & 95 & 95 & 95 & 95 & 90 & 95 \\
\hline & Hoog & 110 & 100 & 90 & 90 & 85 & 85 & 85 & 80 & 75 \\
\hline \multirow{3}{*}{ Akkerland } & Neutraal & 95 & 85 & 80 & 75 & 70 & 65 & 65 & 60 & 70 \\
\hline & Ruim voldoende & & & & & & & & & 60 \\
\hline & Hoog & 95 & 85 & 75 & 70 & 65 & 55 & 55 & 50 & 40 \\
\hline
\end{tabular}

1 De fosfaattoestand voor grasland is uitgedrukt in de PAL-waarde, voor akkerland in de Pw-waarde. De klasse-indeling van P-toestanden is vanaf 2020 aangepast (Bron: Zesde Actieprogramma Nitraatrichtlijn).

\subsection{Derogatie}

In de Nitraatrichtlijn geldt voor alle EU-lidstaten de regel van een maximale bemesting van landbouwgrond met $170 \mathrm{~kg}$ stikstof per ha uit dierlijke mest in landsdelen die als nitraatgevoelig gebied zijn aangewezen of indien een lidstaat, zoals Nederland, het actieprogramma toepast op het hele grondgebied. Nederland heeft een derogatie voor gebruik van $230 \mathrm{~kg} \mathrm{~N}$ per ha (voor zand- en lössgronden in Midden- en Zuid-Nederland) en $250 \mathrm{~kg} \mathrm{~N}$ per ha (voor zandgronden in de overige gebieden en overige grondsoorten) voor graasdierenmest op bedrijven waarvan het areaal uit minimaal $80 \%$ grasland bestaat. Aan een derogatie worden allerlei eisen gesteld, zoals grenzen aan de 
nationale mestproductie (stikstof- en fosfaatplafonds: mestproductie uitgedrukt in stikstof en fosfaat moet lager zijn dan het niveau van jaar 2002) en er mag geen fosfaatkunstmest worden toegepast op bedrijven met een derogatie. In juni 2020 zijn aanvullende eisen gesteld voor de derogatie in 2020 en 2021 met betrekking tot de temperatuur waarbij drijfmest met een sleepvoetbemester op grasland op klei- of veengrond mag worden toegediend (sleepvoetbemesting is niet toegestaan op grasland op zandgrond; mest moet met een zodenbemester worden toegediend).

\subsection{Samenvatting}

De belangrijkste instrumenten/maatregelen uit het mest- en ammoniakbeleid zijn het gebruiksnormenstelsel, voorschriften ter beperking van nutriëntenuitspoeling, voorschriften ter beperking van ammoniakemissies, productierechten ter beperking van de productie van dierlijke mest, verantwoorde mestafzet en verplichte mestverwerking en een regeling voor de samenstelling van meststoffen. In actieprogramma's voor de Nitraatrichtlijn worden elke vier jaar maatregelen opgenomen om nitraatuitspoeling te beperken. Belangrijke nieuwe maatregelen die in het kader van het Vijfde Actieprogramma Nitraatrichtlijn (2014-2017) zijn geïmplementeerd om uitspoeling te beperken, zijn de verlaging van de gebruiksnormen voor uitspoelingsgevoelige gewassen in het zuidelijk zand- en lössgebied met $20 \%$ en de verlaging van de gebruiksnorm dierlijke mest van 250 naar $230 \mathrm{~kg} \mathrm{~N}$ per ha voor zand- en lössgrond voor bedrijven met een derogatie in de zandgebieden in Zuid- en MiddenNederland en de lössregio. In het kader van het Zesde Actieprogramma Nitraatrichtlijn (2018-2021) zijn in 2019 strengere eisen gesteld aan een vanggewas na maïs op zand- en lössgrond. In 2020 is de klasse-indeling van de fosfaatgebruiksnormen aangepast en is de fosfaatgebruiksnorm bij toestand 'hoog' verlaagd. Andere maatregelen om uitspoeling te beperken uit dit programma worden pas in 2021 geïmplementeerd. 


\subsection{Effecten van het weer op stikstof- en fosfaatuitspoeling en waterkwaliteit}

De hoeveelheid neerslag en de temperatuur kunnen via verschillende mechanismen in de bodem een effect hebben op de kwaliteit van grond- en oppervlaktewater, namelijk via factoren die leiden tot een hoger of lager stikstof- en/of fosfaatoverschot, verdunnings-/indikkingseffecten door verandering in de hoeveelheid uitspoelend water (neerslagoverschot), biologische processen in de bodem en sloot en transportroutes van stikstof en fosfaat in de bodem naar grond- en oppervlaktewater (CDM, 2020a). Hieronder wordt een overzicht gegeven van de factoren die een rol spelen bij effecten van het weer op de uitspoeling van stikstof en fosfaat.

Factoren die leiden tot een verandering in het stikstof- en/of fosfaatoverschot (verschil tussen aanvoer en afvoer van stikstof en fosfaat naar een perceel)

- De vochtvoorziening heeft een groot effect op de gewasopbrengst en daarmee de stikstof- en fosforopname door het gewas. Droogte leidt tot lagere opbrengsten en een hoger stikstofoverschot van de bodem, waardoor het risico op nitraatuitspoeling toeneemt. Bij snijmaïs was bijvoorbeeld sprake van relatief lage opbrengsten in 2018. Door de droogte in 2018 is het stikstofoverschot van de bodem van bedrijven met een derogatie gemiddeld met $12 \%$ gestegen in vergelijking met voorgaande jaren (Lukács et al., 2020). Ook in Duitsland waren de opbrengsten veel lager (10-35\%) en stikstofoverschotten veel hoger in 2018 dan in eerdere jaren (Klages et al., 2020).

- Een hoog stikstofoverschot na een droog groeiseizoen kan, afhankelijk van de hoeveelheid neerslag in de winter, leiden tot een verhoogd gehalte aan minerale stikstof in de bodem in het daaropvolgend voorjaar (Klages et al., 2020). Indien de bemesting niet wordt aangepast aan deze hoeveelheid en er meer stikstof wordt toegediend dan het gewas kan opnemen, neemt het risico op nitraatuitspoeling toe.

- Droogte veroorzaakt een vochttekort in de bodem en daardoor neemt de diffusiesnelheid van nutriënten in de bodem af. Vooral bij fosfaat speelt dit een rol (Ehlert en De Willigen, 1999). Dit heeft als consequentie dat gemiddeld genomen een hogere fosfaattoestand nodig is om het gewas met voldoende fosfaat te kunnen voeden. Droogte kan dus leiden tot een verminderde fosfaatbeschikbaarheid, waardoor de groei vertraagt. Bij gelijkblijvende bemesting leidt een lagere opbrengst tot een hoger fosfaatoverschot en een hoger stikstofoverschot.

Verdunnings-/indikkingseffecten door de hoeveelheid uitspoelend water (neerslagoverschot)

- Hoe minder water er uitspoelt, hoe minder de verdunning van het uitspoelende nitraat, hoe hoger de nitraatconcentratie in het uitspoelingswater en hoe trager de nitraat naar de ondergrond uitspoelt.

Biologische processen in de bodem en sloot

- Minder afbraak van nitraat door denitrificatie in de bovengrond en ondergrond als gevolg van droge omstandigheden, waardoor er meer nitraat kan uitspoelen. Denitrificatie is het microbiologische proces waarbij nitraat onder zuurstofloze (natte) omstandigheden wordt afgebroken tot de gasvormige stikstofverbindingen stikstofgas $\left(\mathrm{N}_{2}\right)$, lachgas $\left(\mathrm{N}_{2} \mathrm{O}\right)$ en stikstofoxide $(\mathrm{NOx})$.

- Het vochtgehalte van de bodem is een belangrijke factor voor stikstofmineralisatie; droogte leidt tot een lagere stikstofmineralisatie. Na voldoende regenval en het weer nat worden van de droge grond kan een versterkte mineralisatie van organisch gebonden stikstof in de bodem optreden (Birch, 1964). Daardoor kan er na een droge periode gevolgd door een natte periode extra minerale stikstof beschikbaar komen voor het gewas en voor uitspoeling.

- De temperatuur in het oppervlaktewater heeft effect op biologische afbraakprocessen en zuurstofconsumptie, zoals omzettingen in de slootbodem, algengroei en algensterfte. De lagere stroomsnelheid en langere verblijftijd van water spelen hierbij een belangrijke rol. Deze processen kunnen leiden tot fluctuaties in de stikstof- en fosfaatconcentraties in het oppervlaktewater. Bij 
droogte, hoge temperaturen en lage stroomsnelheden kan zuurstofloosheid in de waterbodem ontstaan. Naast effect op biologische processen en groei van waterplanten, kan zuurstofloosheid tot extra vrijkomen van fosfaat uit de waterbodem leiden.

- Door droogte verslechtert de zode van grasland, waardoor onkruid meer kans krijgt zich te ontwikkelen. Het productievermogen en de nutriëntenopnamecapaciteit van het grasland nemen daardoor af, waardoor bij gelijkblijvende bemesting meer stikstof en andere nutriënten in de bodem achterblijven en later in het jaar kunnen uitspoelen. De noodzaak van herinzaai van het grasland neemt toe, waardoor een extra nitraatuitspoeling kan optreden.

Transportroutes van stikstof en fosfaat in de bodem naar grond- en oppervlaktewater

- In een droge periode kan er scheurvorming in de kleibodem optreden, met een risico op preferent transport van nitraat (maar ook fosfaat) naar drains en oppervlaktewater bij regenval.

- In natte jaren heeft relatief stikstofrijk grondwater uit ondiepe lagen een grote bijdrage aan de belasting van het oppervlaktewater, terwijl in droge jaren het diepere grondwater met (meestal) een relatief lage stikstofconcentratie een belangrijk aandeel heeft (Rozemeijer en Broers, 2007; Rozemeijer et al., 2010). Dit impliceert dat schommelingen in de nitraatconcentratie van oppervlaktewater niet altijd direct aan meer of minder uitspoeling van nitraat uit de bovengrond gerelateerd kunnen worden.

- Zandgronden kunnen tijdens droge omstandigheden waterafstotende eigenschappen krijgen (hydrofobie), waardoor bij forse regenval toegediende nutriënten oppervlakkig kunnen afspoelen en/of via preferente stroombanen snel naar de ondergrond stromen (Dekker, 1998; Booltink, 2015).

- Fosfaatmeststoffen die oppervlakkig zijn toegediend en niet zijn ingewerkt, lossen bij droogte niet of heel langzaam op en worden niet omgevormd tot bodemfosfaat. Als er na een droge periode regen valt, kan oppervlakkige afspoeling van fosfaat uit niet-opgeloste fosfaatmeststoffen optreden.

Hydrologische factoren in het oppervlaktewater

- De herkomst van water dat in de zomerperiode naar het oppervlaktewater afstroomt, is anders dan in de winterperiode. In de zomerperiode heeft het diepere grondwater een relatief groter aandeel in de afvoer. Dit effect is groter naarmate de grondwaterstand lager is door een groter neerslagtekort. In droge perioden spoelt er weinig stikstof en fosfaat uit en treedt er minder verdunning met water op dan onder normale omstandigheden.

- In drogere perioden vallen meer kavelsloten droog dan onder normale omstandigheden en het aantal landbouwpercelen dat in de zomer geen directe afvoer heeft naar het oppervlaktewater neemt toe. Omdat onder drogere omstandigheden een kleiner gebied het oppervlaktewater belast met nutriënten kan de samenstelling anders zijn dan onder normale omstandigheden.

- In veel gebieden wordt in de zomerperiode water aangevoerd vanuit de grotere wateren. Dit vindt ook plaats in het noordelijke zandgebied, Noord-Limburg en in het oostelijke deel van NoordBrabant. Naarmate een zomer droger is, wordt meer water aangevoerd, mits aanwezig, en wordt het gebiedseigen water in grotere mate vermengd met het aangevoerde water.

- Bij droogte neemt de relatieve invloed van kwel en/of RWZI-effluent op de oppervlaktewaterkwaliteit toe.

Het management van de boer is van invloed op bovengenoemde factoren en mechanismen. Bij droogte zal een boer zijn gewas beregenen, mits dat mogelijk en toegestaan is. In de zomer van 2018 werd bijvoorbeeld ruim $150 \%$ meer water gebruikt voor beregening dan in 2017 , en ruim $50 \%$ meer dan in 2003, een met 2018 vergelijkbaar droog jaar (CBS, 2020). ${ }^{3}$ Beregening kan de uit- en afspoeling van nutriënten doen toenemen via effecten op de hierboven geschetste transportroutes van nutriënten. Bij droogte zal een boer keuzes moeten maken over het wel of niet uitrijden van mest voor 1 september, het al dan niet scheuren van grasland, het vroegtijdig inzaaien van een vanggewas of groenbemester, het verminderen/stoppen van bemesting door lagere opbrengsten, de beweiding in het najaar en het al dan niet onderwerken van een door droogte mislukt gewas. Al deze keuzes kunnen direct of indirect een effect hebben op het stikstof- en fosfaatoverschot en op de waterkwaliteit.

\footnotetext{
3 https://www.cbs.nl/nl-nl/nieuws/2020/12/piek-watergebruik-huishoudens-en-landbouw-in-2018
} 


\subsection{Trends in temperatuur en neerslag}

De jaargemiddelde temperatuur in Nederland is trendmatig en statistisch significant toegenomen en ligt in $20192,1 \pm 0,6^{\circ} \mathrm{C}$ hoger dan in 1907 (Figuur 1). Het jaar 2014 was veruit het warmste jaar sinds het begin van de meetreeks, direct gevolgd door de jaren 2018 en 2019. Uit een analyse beschreven op het Compendium van de Leefomgeving blijkt dat de maximumtemperatuur in de zomer toeneemt en dat de winters minder koud zijn. ${ }^{4}$

De jaarlijkse hoeveelheid neerslag in Nederland laat een zeer geleidelijke toename zien in de hele periode 1910-2019 (Figuur 2). In 1910 bedroeg de trendwaarde $692 \mathrm{~mm}$ en in het eindjaar 2019 is dat opgelopen naar $873 \mathrm{~mm}$. De totale hoeveelheid neerslag varieert sterk van jaar op jaar. Zo bedroeg de neerslaghoeveelheid $436 \mathrm{~mm}$ in 1921 en $1111 \mathrm{~mm}$ in 1998. De droogste jaren in de recente decennia waren 2003 en 2018.

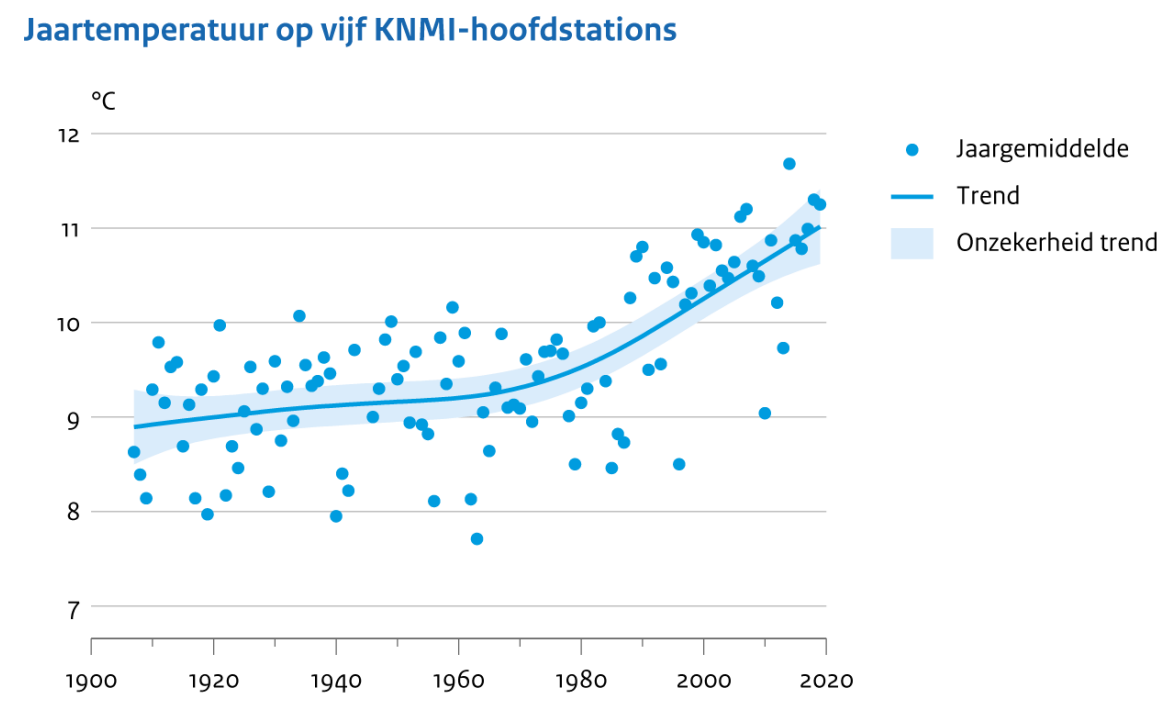

Bron: KNMI

Figuur 1 Jaargemiddelde temperatuur in Nederland (Bron: Compendium voor de Leefomgeving).

\section{Hoeveelheid neerslag}
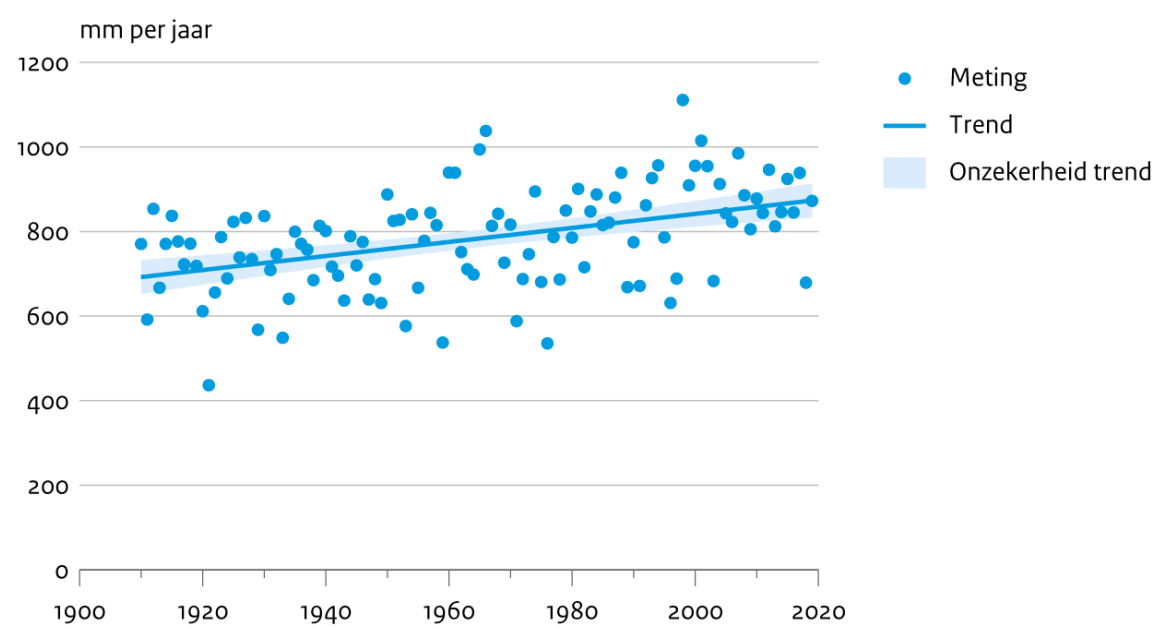

Bron: KNMI; bewerking PBL

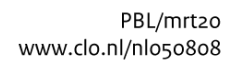

Figuur 2 Hoeveelheid neerslag in Nederland (Bron: Compendium voor de Leefomgeving).

\footnotetext{
${ }^{4}$ https://www.clo.nl/indicatoren/nl0589-temperatuur-extremen
} 
Gemiddeld over een jaar is de hoeveelheid neerslag in Nederland hoger dan de verdamping van gewas en bodem. Het gemiddelde jaarlijkse neerslagoverschot in de periode 1981-2010 bedraagt zo'n $300 \mathrm{~mm}$, maar met een grote variatie tussen regio's (Figuur 3). Het neerslagtekort is het verschil tussen verdamping en de hoeveelheid neerslag; het neerslagtekort in de periode april tot en met september is de indicator die het KNMI gebruikt voor droogte in het groeiseizoen. Zoals hierboven aangegeven, hebben de temperatuur en de hoeveelheid neerslag (en het neerslagoverschot) een groot effect op de uitspoeling van stikstof en fosfaat en de waterkwaliteit. Hierbij speelt het verloop van neerslag en neerslagoverschot in relatie tot bemestingstijdstippen en verloop van gewasgroei een belangrijke rol. Ook de hoeveelheid neerslag in de winter heeft een grote invloed op de waterkwaliteit.

Tussen de jaren bestaan er grote verschillen in de hoogte van het neerslagtekort in het groeiseizoen en het verloop in de tijd. Als voorbeeld wordt in Figuur 4 het verloop van het neerslagtekort in de periode april-september weergegeven voor de jaren 2017, 2018 en 2019 en 2020. In 2017 verliep het neerslagtekort in de periode april tot half mei normaal (vergelijkbaar als de meerjarige mediaan), gevolgd door een droge periode (half mei tot eind juni). De zomer van 2017 was relatief nat. In 2018 verliep het neerslagtekort normaal in het voorjaar, maar namen het neerslagtekort en de droogte toe in de maanden juni-juli. Augustus 2018 was warm en droog. In 2019 was het voorjaar droog, was de eerste helft van de maand juni nat, was de maand juli droog met hoge temperaturen en waren de maanden augustus/september weer relatief nat. De maanden april-mei 2020 waren warm en droog, gevolgd door een relatief natte maand juni. In juli is het neerslagtekort verder opgelopen, gevolgd door een natte periode begin augustus. Het verschil in neerslagtekort eind september was groot tussen de jaren: 56 mm in 2017, 296 mm voor 2018, $160 \mathrm{~mm}$ voor 2019 en $207 \mathrm{~mm}$ in 2020. Naast grote variatie tussen jaren, is er ook een grote variatie in de ruimte, zoals in Figuur 6 is geïllustreerd voor 2018, 2019 en 2020. Het neerslagtekort was in de afgelopen drie zomers het grootst in Twente, Oost-Gelderland en Zuidoost-Nederland. Droogte is in de loop van de tijd vaker voorgekomen (bijvoorbeeld de jaren 1976 en 2003). Wat bijzonder is, is dat droogte nu in drie opeenvolgende jaren (2018, 2019 en 2020) voorkomt. Mogelijk dat door klimaatverandering in de toekomst droogte vaker zal voorkomen.

Zware neerslag in Nederland is ook sterk toegenomen in de tijd. Het opvallendst is de toename in het aantal dagen met neerslag van meer dan $50 \mathrm{~mm}$ neerslag ergens in Nederland (Figuur 5). Dit aantal is sinds 1951 toegenomen met $70 \%$. Ook is het aantal dagen per jaar met meer dan 20 mm neerslag per dag sterk toegenomen. ${ }^{5}$

\footnotetext{
${ }^{5}$ https://www.clo.nl/indicatoren/n10590-neerslag-extremen
} 


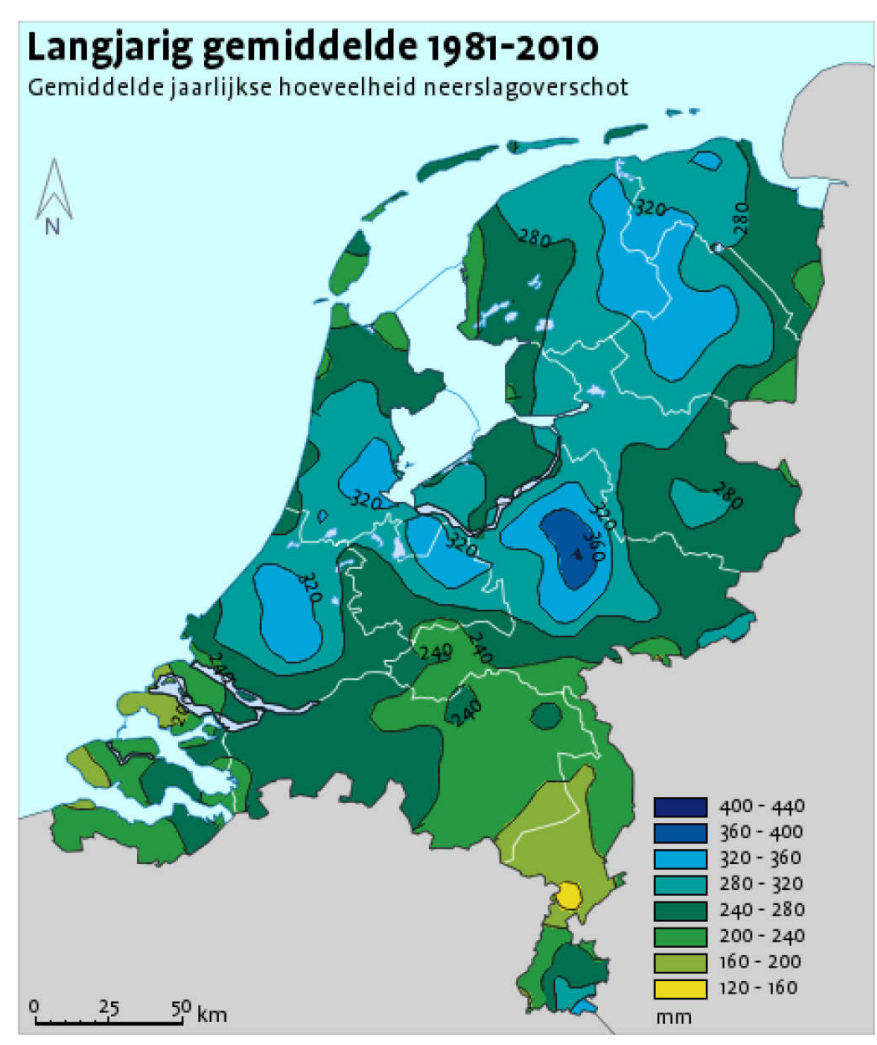

Figuur 3 Langjarig gemiddelde jaarlijkse neerslagoverschot (Bron: KNMI). ${ }^{6}$
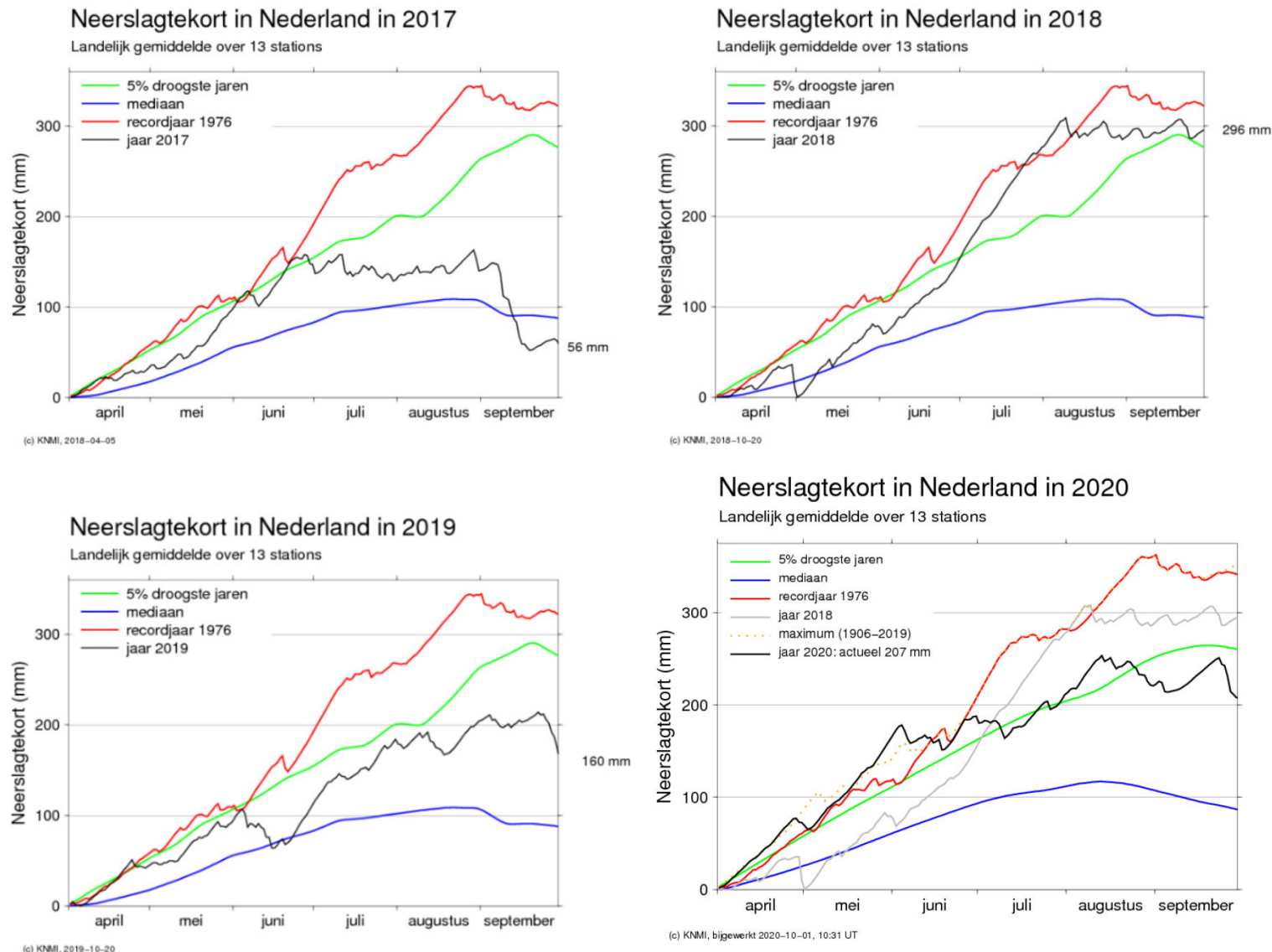

Figuur 4 Verloop neerslagtekort in de periode april tot en met september in 2017, 2018, 2019 en 2020. De mediaan, het maximum en de 5\% droogste jaren zijn gebaseerd op de periode 1906-2019 (Bron: KNMI).

\footnotetext{
6 http://www.klimaatatlas.nl/klimaatatlas.php
} 


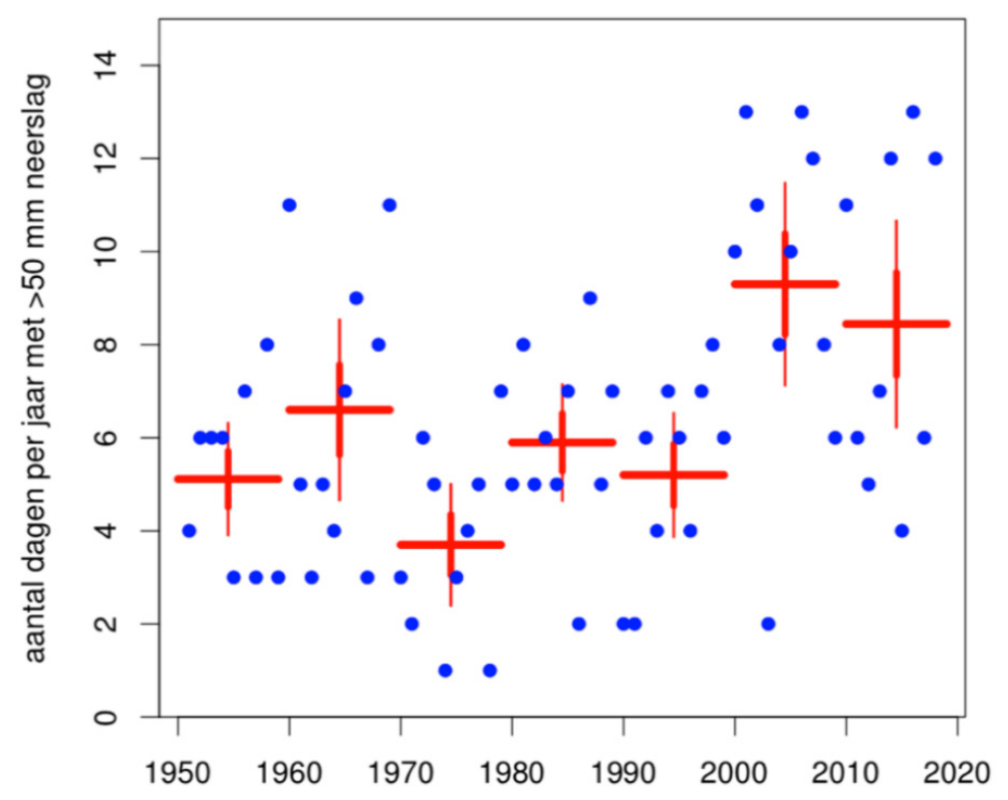

Figuur 5 Aantal dagen met zware neerslag (>50 mm). Blauwe punten: aantal dagen voor ieder jaar, rode horizontale lijnen: gemiddelden over tienjaarperioden, verticale lijnen: 1 (dik) en 2 (dun) maal de standaarddeviatie in de schatting $\mathrm{v} / \mathrm{h}$ gemiddelde (Bron: KNMI). ${ }^{7}$

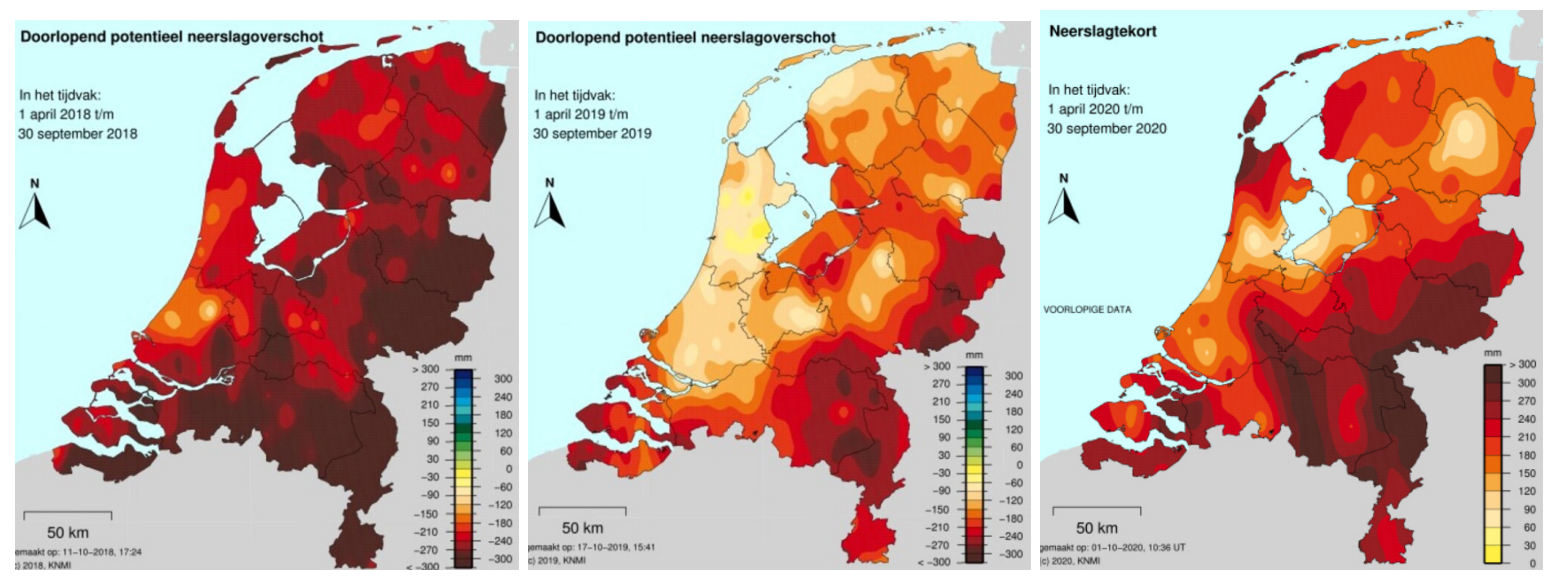

Figuur 6 Ruimtelijk beeld van het neerslagtekort in 2018, 2019 en 2020 (Bron: KNMI).

\subsection{Samenvatting}

De hoeveelheid neerslag en de temperatuur kunnen via verschillende mechanismen in de bodem een effect hebben op de kwaliteit van grond- en oppervlaktewater, namelijk via factoren die leiden tot een hoger of lager stikstof- en/of fosfaatoverschot, verdunnings-/indikkingseffecten door de hoeveelheid uitspoelend water (neerslagoverschot), biologische processen in de bodem en sloot en transportroutes van stikstof en fosfaat in de bodem naar grond- en oppervlaktewater. De jaargemiddelde temperatuur in Nederland is trendmatig en statistisch significant toegenomen en ligt in $20192,1 \pm 0,6^{\circ} \mathrm{C}$ hoger dan in 1907. De verschillen in weer tussen jaren is groot. In de jaren 2017, 2018, 2019 en 2020 kwamen droge perioden voor, vaak gevolgd door nattere perioden. Ook de ruimtelijke variatie binnen Nederland in neerslagtekorten is zeer groot. Het aantal dagen met zware neerslag is ook toegenomen in de tijd. Zware neerslag kan in de landbouw tot wateroverlast leiden met een mislukte teelt als gevolg. Daarnaast leidt zware neerslag tot oppervlakkige afstroming van water, wat gepaard kan gaan met transport van sediment (erosie) en de afspoeling van nutriënten.

\footnotetext{
7 https://www.knmi.nl/kennis-en-datacentrum/uitleg/extreme-neerslag
} 


\section{$4 \quad$ Ontwikkelingen in de landbouw}

\subsection{Bedrijven}

De schaalvergroting neemt toe in de landbouw in de periode 2010-2019; het aantal bedrijven neemt af en het oppervlakte per bedrijf neemt toe bij de meeste bedrijfstypen (Tabel 2). Het aantal bedrijven is tussen 2010 en 2019 gedaald met 8\% voor akkerbouwbedrijven, 33\% voor tuinbouwbedrijven, 31\% voor graasdierbedrijven (incl. melkvee), $15 \%$ voor melkveebedrijven en $13 \%$ voor hokdierbedrijven. In 2019 was de gemiddelde oppervlakte per bedrijf 42 ha voor akkerbouwbedrijven, 56 ha voor melkveebedrijven, 14 ha voor tuinbouwbedrijven en 13 ha voor hokdierbedrijven.

Tabel 2 Aantal landbouwbedrijven, oppervlakte en oppervlakte per bedrijf voor enkele bedrijfstypen in 2020, 2015 en 2019 (Bron: CBS-Statline).

\begin{tabular}{|c|c|c|c|c|}
\hline Bedrijfstypen & Perioden & Aantal bedrijven & Oppervlakte (ha) & $\begin{array}{l}\text { Oppervlakte per } \\
\text { bedrijf, ha/bedrijf }\end{array}$ \\
\hline \multirow[t]{2}{*}{ Akkerbouwbedrijven } & 2010 & 11960 & 460568 & 39 \\
\hline & 2019 & 10980 & 455790 & 42 \\
\hline \multirow[t]{2}{*}{ Tuinbouwbedrijven } & 2010 & 10200 & 92091 & 9 \\
\hline & 2019 & 6785 & 94879 & 14 \\
\hline \multirow[t]{3}{*}{ Graasdierbedrijven } & 2010 & 38025 & 1077319 & 28 \\
\hline & 2015 & 33640 & 1071846 & 32 \\
\hline & 2019 & 26295 & 1037159 & 39 \\
\hline waarvan melkveebedrijven & 2010 & 17520 & 817252 & 47 \\
\hline \multirow[t]{3}{*}{ Hokdierbedrijven } & 2010 & 6480 & 75961 & 12 \\
\hline & 2015 & 5105 & 65270 & 13 \\
\hline & 2019 & 4440 & 58948 & 13 \\
\hline
\end{tabular}

\subsection{Gewassen}

\subsubsection{Uitspoelingsgevoeligheid van gewassen}

Het landgebruik en de gewaskeuze hebben een effect op de nitraatuitspoeling, omdat er verschillen bestaan in uitspoelingsgevoeligheid tussen gewassen. Verschillende factoren bepalen de uitspoelingsgevoeligheid van gewassen, zoals de afstemming van de stikstofbemesting op de gewasbehoefte, de benutting van stikstof (die in de bodem aanwezig is) door het gewas, de totale hoeveelheid stikstof die wordt opgenomen, de lengte van de stikstofopnameperiode, de hoeveelheid stikstof in niet-geoogste gewasresten en gewaseffecten op stikstofomzettingen in de bodem (zoals denitrificatie en immobilisatie).

Uitspoelingsgevoelige gewassen zijn in 2006 gedefinieerd als gewassen waarvan de nitraatuitspoeling bij toepassing van de (toenmalige) landbouwkundig bemestingsadviezen leidt tot overschrijding van 50 mg nitraat per L in het uitspoelende water (Van Dijk en Schröder, 2007). Tot uitspoelingsgevoelige gewassen behoren de gewassen uit de groepen aardappelen, groenten en maïs (snij- en korrelmaïs). De stikstofgebruiksnormen voor uitspoelingsgevoelige gewassen zijn sinds 2014 (implementatie van het Vijfde Actieprogramma Nitraatrichtlijn) lager voor zand- en lössgronden in het zuidelijke zand- en 
lössgebied dan in de overige zandgebieden. ${ }^{8}$ Suikerbieten werden in 2006 nog als uitspoelingsgevoelig gekenmerkt door Van Dijk en Schröder (2007) en zijn ook zo opgenomen in de Meststoffenwet. Gezien de sterke stijging van de opbrengst van suikerbieten sinds 2006 (gemiddelde 3\% opbrengststijging per jaar) mag worden verwacht dat suikerbieten nu niet meer uitspoelingsgevoelig zijn (Velthof et al., 2017).

Bij fosfaat wordt geen onderscheid gemaakt in uitspoelingsgevoeligheid; de gebruiksnormen zijn gebaseerd op de fosfaattoestand van de bodem. In het landbouwkundig bemestingsadvies van akkerbouwgewassen wordt bij de advisering van fosfaatbemesting onderscheid gemaakt tussen gewasgroepen met verschillen in fosfaatbehoefte. Consumptieaardappelen behoren tot de fosfaatbehoeftige gewassen en granen tot de gewassen met een lage fosfaatbehoefte. In een gewasrotatie zal binnen de fosfaatgebruiksruimte meer fosfaat worden toegediend aan consumptieaardappelen dan aan granen. Dit leidt tot een hoger risico op fosfaatafspoeling bij consumptieaardappelen dan bij granen. Dit verschil wordt versterkt doordat bij consumptieaardappelen de bodem onbedekt is in de winter, terwijl er bij wintergranen een gewas aanwezig is.

\subsubsection{Arealen}

Het areaal cultuurgrond is in de periode 2010-2019 met 3\% gedaald (Figuur 7). De arealen permanent grasland, snijmaïs en granen zijn afgenomen in deze periode en tijdelijk grasland, aardappelen en suikerbieten zijn toegenomen. In 2019 was het areaal snijmaïs 187.000 ha, duidelijk minder dan in de jaren ervoor (zo'n 205.000 ha in de periode 2016-2018). Het areaal wintertarwe is toegenomen in 2019 (112.000 ha) ten opzichte van 2018 (96.000 ha). De afname in het areaal snijmaïs is vergelijkbaar met de toename bij wintertarwe. Waarschijnlijk hebben boeren een deel van de mislukte snijmaïs na de droge zomer in 2018 omgeploegd voor de teelt van wintertarwe.

Uit onderzoek blijkt dat de laatste jaren minder melkveebedrijven gebruikmaken van de derogatie en daardoor niet meer hoeven te voldoen aan de derogatie-eis dat het areaal uit minimaal $80 \%$ grasland moet bestaan (Hoogeveen et al., 2019). De kwaliteit van grond- en oppervlaktewater kan verslechteren als grasland wordt vervangen door uitspoelingsgevoelige gewassen. In Figuur 8 zijn de arealen (in procenten van het totaal areaal) in 2010 en 2018 samengevat voor de verschillende zandgebieden. In 2018 was het areaal uitspoelingsgevoelige gewassen $43 \%$ van het totaalareaal in het zuidelijk zandgebied, $25 \%$ in het centraal zandgebied, $31 \%$ in het noordelijk zandgebied en $25 \%$ in het lössgebied. Er zijn geen grote veranderingen opgetreden in het areaal uitspoelingsgevoelige gewassen tussen 2010 en 2018. Het areaal snijmaïs is afgenomen tussen 2010 en 2018, omdat het minimale aandeel grasland om te mogen deelnemen aan derogatie in 2014 is verhoogd van $70 \%$ naar $80 \%$. Zoals hierboven aangegeven, is het areaal snijmaïs in 2019 verder afgenomen, maar waarschijnlijk is dit een tijdelijk effect van het droge jaar 2018.

\footnotetext{
8 https://zoek.officielebekendmakingen.nl/stcrt-2014-22547.html
} 


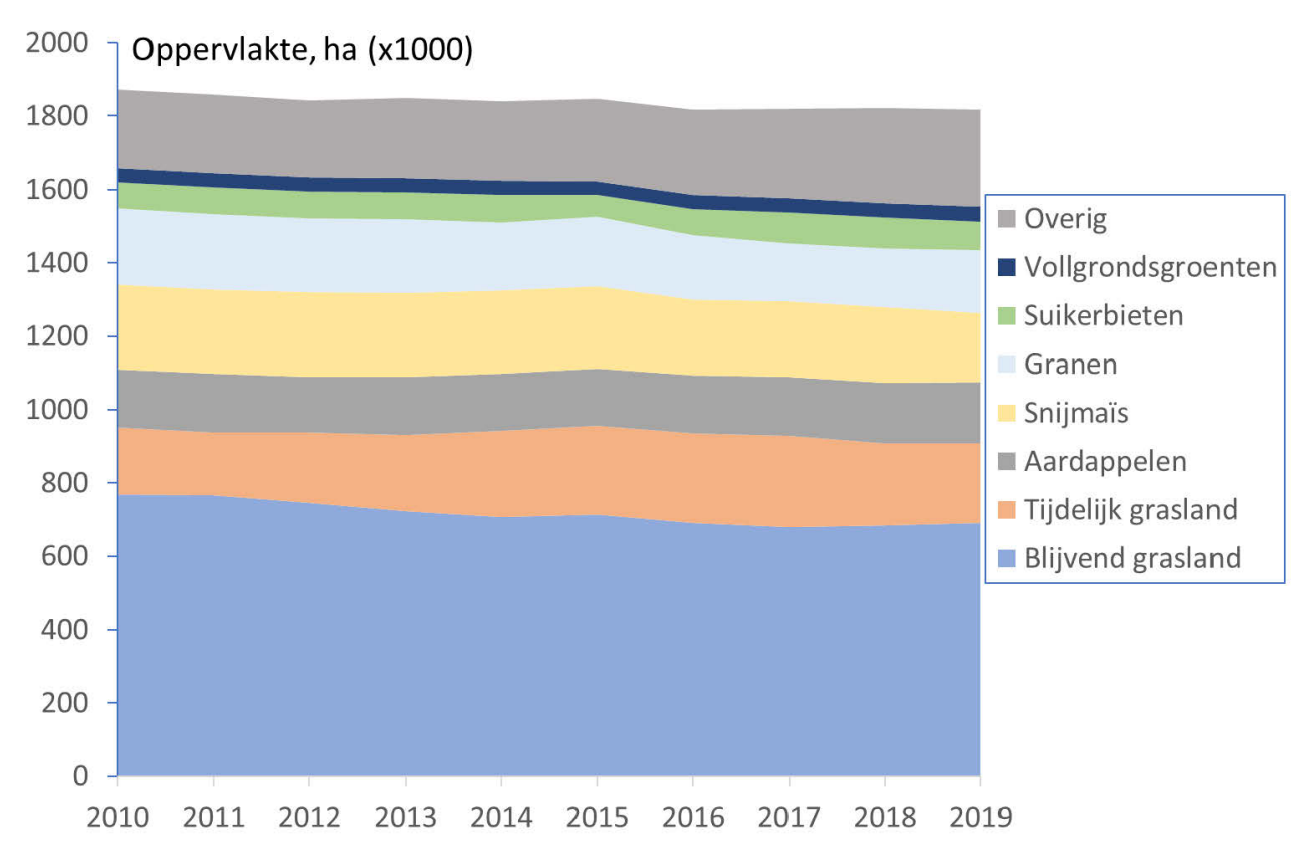

Figuur 7 Arealen van gewassen in Nederland (x 1000 ha) (Bron: CBS).

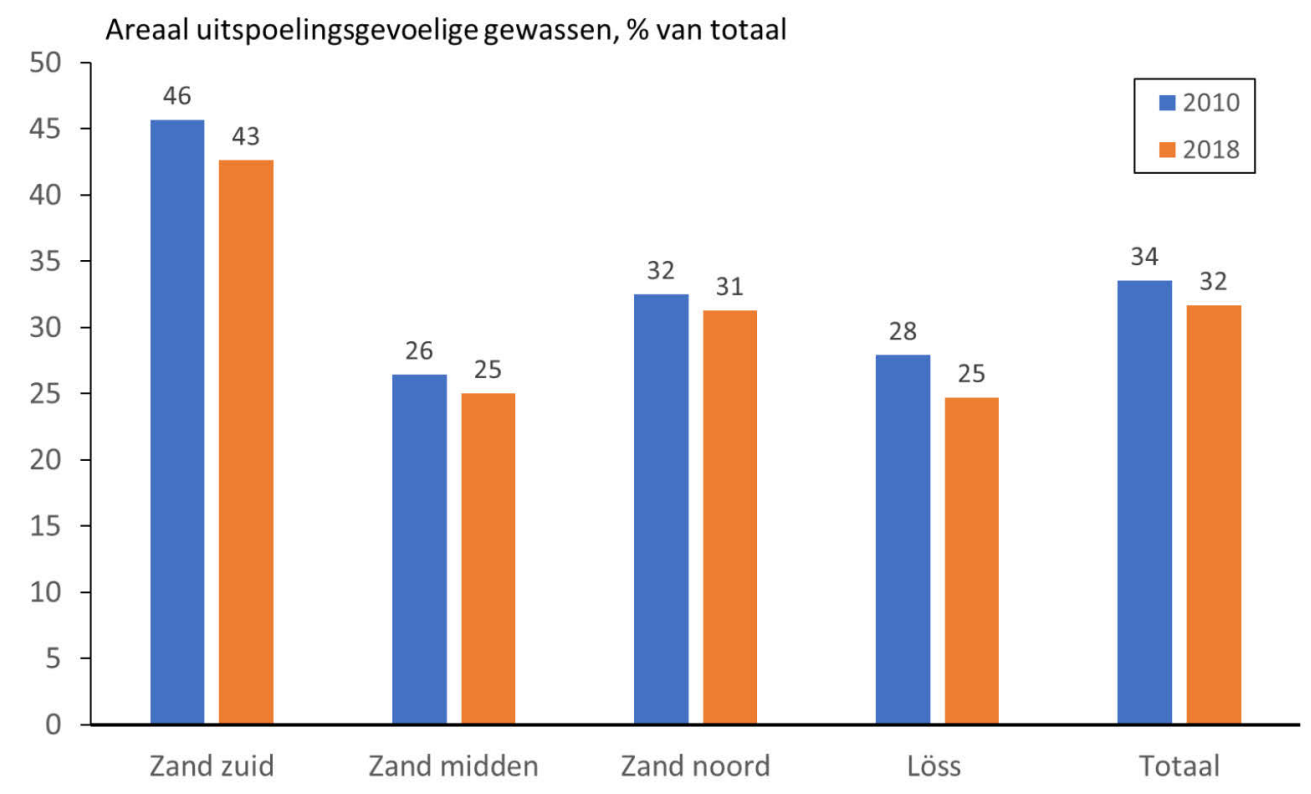

Figuur 8 Arealen uitspoelingsgevoelige gewassen (excl. suikerbieten), in procenten van het totale landbouwareaal (excl. braak en natuur) in 2010 en 2018 in de drie zandregio's en in het lössgebied (CDM, 2020c).

\subsubsection{Opbrengsten}

De opbrengsten van akkerbouwgewassen fluctueren de laatste jaren (Figuur 9). Het weer heeft een groot effect. In het droge jaar 2018 was de opbrengst bij veel gewassen relatief laag. Door de sterke fluctuaties tussen jaren is er geen duidelijk trend in opbrengst sinds 2010. De opbrengsten suikerbieten en wintertarwe lijken iets te stijgen. Ook de opbrengst van grasland was relatief laag in 2018 (Figuur 10). Op derogatiebedrijven was zowel de N- als P-opname in 2018 van grasland lager dan in eerdere jaren. Ook bij snijmaïs is een daling te zien in opbrengst (Figuur 10). 


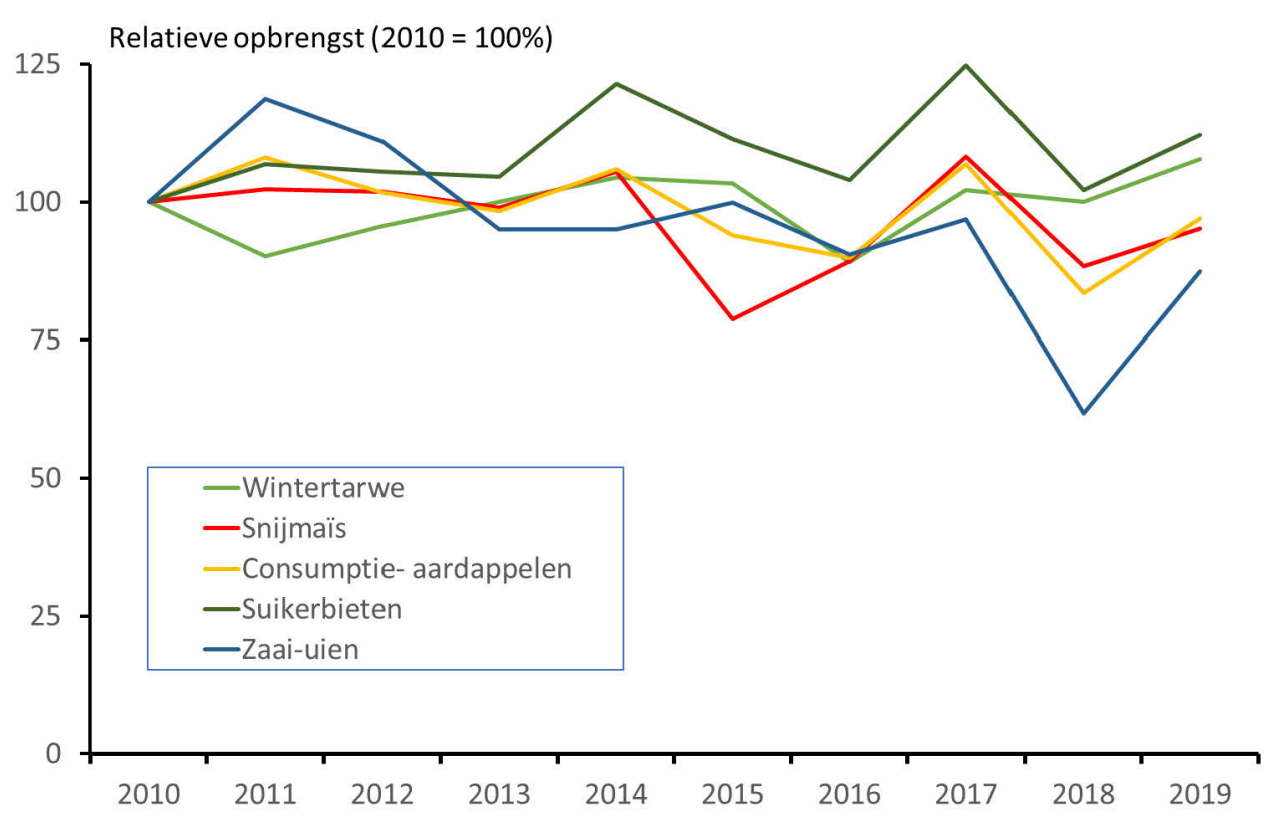

Figuur 9 Relatieve opbrengsten in de periode 2010-2019 voor enkele akkerbouwgewassen. 2010 is op $100 \%$ gesteld (Bron: CBS Statline).

Het stikstof- en fosfaatoverschot, en daarmee het risico op stikstof- en fosfaatuitspoeling, wordt niet alleen bepaald door de drogestofopbrengst, maar ook door het stikstof- en fosforgehalte van het gewas. Het stikstofgehalte in gras was de laatste jaren, en met name in 2018, relatief hoog (Tabel 3). Het hoge stikstofgehalte in 2018 is waarschijnlijk het gevolg van de droogte, waardoor de bemesting relatief hoog was ten opzichte van de gerealiseerde (lage) gewasopbrengst. Daarnaast zal een hoge stikstofmineralisatie van organische stof en veen ook een rol spelen. Een hoog stikstofgehalte in het ruwvoer is mede oorzaak geweest van de hoge stikstofexcretie door melkvee in recente jaren (paragraaf 5.1).

Tabel 3 Stikstofgehalte in ruwvoer van rundvee (g N per kg droge stof) (Bron: CDM (2020d), op basis van $C B S$ ).

\begin{tabular}{|c|c|c|c|c|c|c|c|}
\hline & 2012 & 2013 & 2014 & 2015 & 2016 & 2017 & 2018 \\
\hline \multicolumn{8}{|l|}{ Graskuil en hooi } \\
\hline gangbaar - stalperiode & 26,5 & 26,5 & 28,2 & 27,7 & 27,0 & 27,9 & 29,8 \\
\hline gangbaar - weideperiode & 27,3 & 25,4 & 28,2 & 28,1 & 27,1 & 26,9 & 29,4 \\
\hline \multicolumn{8}{|l|}{ Snijmaïskuil } \\
\hline stalperiode & 11,6 & 11,0 & 11,3 & 11,2 & 11,1 & 10,9 & 11,4 \\
\hline weideperiode & 12,2 & 10,7 & 11,5 & 11,0 & 11,4 & 10,7 & 11,0 \\
\hline Weidegras voor rundvee en schapen (gangbaar) & 29,1 & 30,7 & 29,7 & 27,5 & 29,0 & 31,2 & 31,2 \\
\hline
\end{tabular}



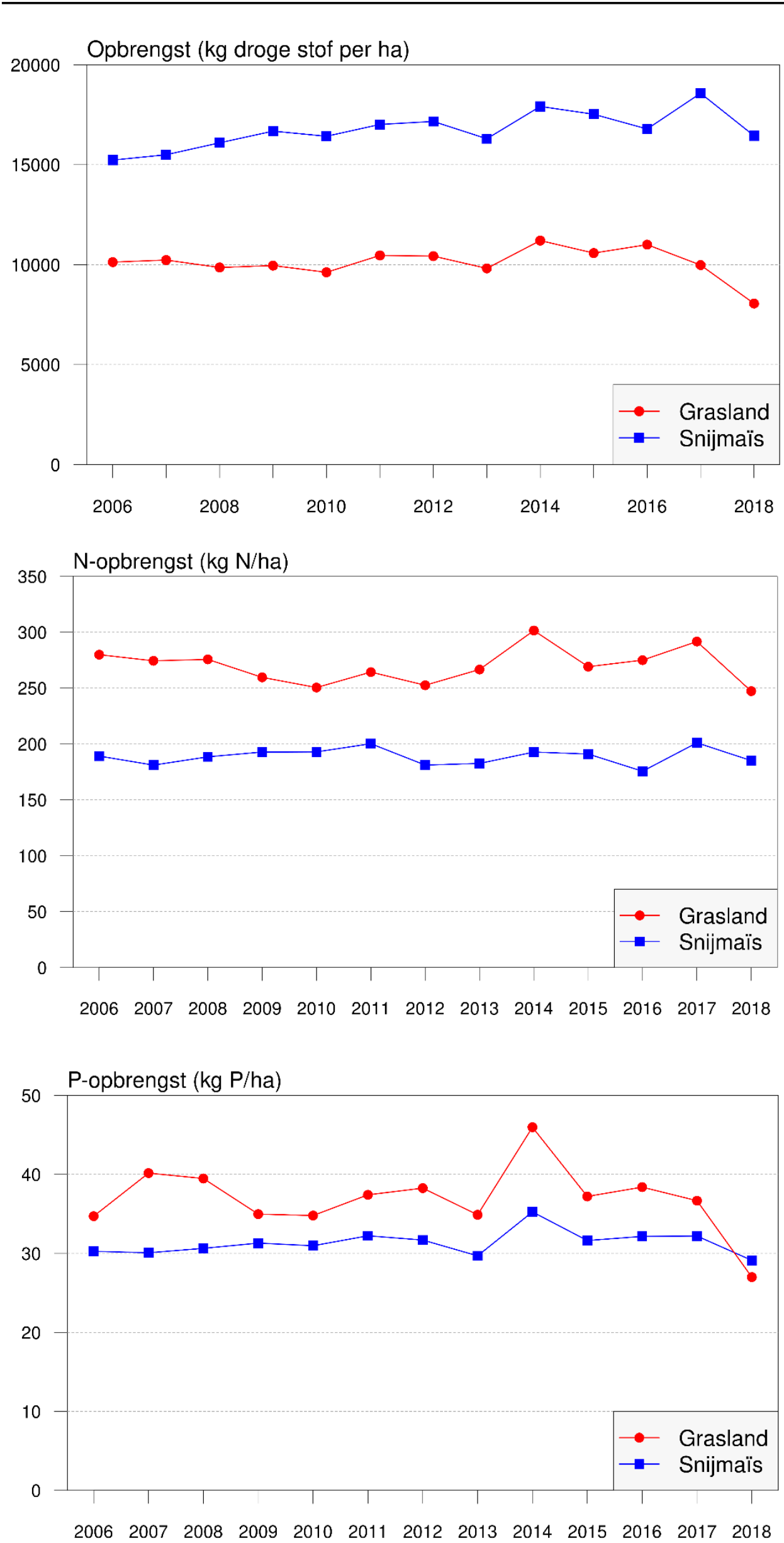

Figuur 10 Gemiddelde drogestofopbrengst (bovenste figuur), stikstofopbrengst (middelste figuur) en fosforopbrengst (onderste figuur) voor grasland en snijmaïs op derogatiebedrijven in de periode 2006-2018 (Lukács et al., 2020). 


\subsection{Veestapel}

\subsubsection{Dieraantallen}

Het aantal melkkoeien is in de periode 2012-2017 sterk gestegen door het wegvallen van het melkquotum in 2015 (Tabel 4). Het aantal is daarna weer afgenomen door het invoeren van het fosfaatrechtensysteem en lag in 2019 op het niveau van 2014. Het aantal varkens is vrij stabiel gebleven in de periode 2010-2019. Het aantal overig rundvee en schapen is iets gedaald in deze periode. Het aantal leghennen is iets gedaald en het aantal slachtkuikens is iets gestegen in de periode 2010-2019. Het aantal geiten is bijna verdubbeld in de periode 2010-2019.

Tabel 4 Aantal landbouwdieren (x 1000) (Bron: CBS-Statline).

\begin{tabular}{lrrrrrrrrrr} 
& 2010 & 2011 & 2012 & 2013 & 2014 & 2015 & 2016 & 2017 & 2018 & $2019 *$ \\
Melk- en kalfkoeien & 1479 & 1470 & 1484 & 1553 & 1572 & 1622 & 1745 & 1694 & 1622 & 1578 \\
\hline Overig rundvee** & 2497 & 2415 & 2395 & 2446 & 2496 & 2511 & 2506 & 2402 & 2297 & 2233 \\
\hline Varkens & 12255 & 12429 & 12234 & 12212 & 12238 & 12603 & 12479 & 12401 & 12430 & 12269 \\
\hline Leghennen & 47904 & 44460 & 42810 & 44816 & 46570 & 47684 & 46212 & 46442 & 47302 & 44319 \\
\hline Slachtkuikens & 44748 & 43912 & 43846 & 44242 & 47020 & 49107 & 49188 & 48237 & 48971 & 48684 \\
\hline Schapen & 1130 & 1088 & 1043 & 1034 & 959 & 946 & 784 & 799 & 866 & 918 \\
\hline Geiten & 353 & 380 & 397 & 413 & 431 & 470 & 500 & 533 & 588 & 615 \\
\hline
\end{tabular}

*voorlopig cijfer

**stieren, overig melk- en fokvee, vlees en weidevee en vleeskalveren

\subsubsection{Melkproductie}

De melkproductie is een belangrijke factor die de mestproductie per koe bepaalt. De melkproductie is sterk gestegen de laatste jaren. De melkproductie in kg per koe per jaar was 8006 in 2012, 7990 in 2013, 8052 in 2014, 8338 in 2015, 8328 in 2016, 8674 in 2017 en 8,848 in 2018 (Bron: CDM, 2020d op basis van gegevens van CBS).

\subsubsection{Beweiding}

Beweiding met melkkoeien bepaalt in welke vorm de mest aan de bodem wordt toegediend. Beweiding, en met name beweiding in de nazomer, leidt tot een verhoogd risico op nitraatuitspoeling (Corré et al., 2014). In urineplekken in beweid grasland is de hoeveelheid stikstof namelijk veel hoger dan de stikstofopnamecapaciteit van het gras. Veranderingen in beweiding kunnen dus leiden tot verandering in nitraatuitspoeling. Beweiding heeft ook effect op andere emissies. Het leidt tot minder ammoniak- en methaanemissie, maar tot meer lachgasemissie. Beweiding heeft ook als nadeel dat de fosfaat veel heterogener wordt verdeeld dan bij toediening van drijfmest.

Weidegang van koeien is in de periode 2010 tot 2017 afgenomen in Nederland; van $74 \%$ in 2010 tot $65 \%$ in 2016. In 2017 en 2018 is weidegang weer iets toegenomen tot $71 \%$ in 2018 . In de afgelopen jaren is veel energie gestoken in behoud van het aandeel weidegang door een scala aan partijen in de gehele zuivelketen in het kader van het Convenant Weidegang. Zo keren zuivelondernemingen een premie uit aan veehouders die hun koeien laten grazen en brengen zij steeds meer producten van weidemelk op de markt. Beweiding wordt gezien als een mogelijke maatregel om ammoniakemissie te beperken. ${ }^{9}$ Dit kan leiden tot een toename van nitraatuitspoeling, met name als beweiding in de nazomer/najaar plaatsvindt.

\footnotetext{
9 https://www.rijksoverheid.nl/documenten/kamerstukken/2020/04/24/voortgang-stikstofproblematiek-structurele-aanpak
} 
Tabel 5 Weidegang van melkvee (ouder dan twee jaar) in Nederland (Bron: CBS, Statline).

\begin{tabular}{|c|c|c|c|c|c|c|c|c|c|c|}
\hline & & 2010 & 2011 & 2012 & 2013 & 2014 & 2015 & 2016 & 2017 & 2018 \\
\hline Bedrijven zonder beweiding & $\%$ bedrijven & 17 & 20 & 21 & 22 & 24 & 24 & 23 & 22 & 20 \\
\hline Bedrijven met beweiding & $\%$ bedrijven & 83 & 80 & 79 & 78 & 76 & 76 & 77 & 78 & 80 \\
\hline Melkvee zonder beweiding & $\%$ dieren & 26 & 29 & 30 & 30 & 31 & 35 & 35 & 32 & 29 \\
\hline Melkvee met beweiding & $\%$ dieren & 74 & 71 & 70 & 70 & 69 & 65 & 65 & 68 & 71 \\
\hline Dag en nacht weiden & $\%$ weideweken & 27 & 25 & 24 & 23 & 22 & 20 & 18 & 17 & 16 \\
\hline Overdag weiden & $\%$ weideweken & 73 & 75 & 76 & 77 & 78 & 80 & 82 & 83 & 84 \\
\hline
\end{tabular}

\subsection{Ammoniakmaatregelen}

Het Nederlandse ammoniakbeleid is erop gericht om de emissies van ammoniak naar de atmosfeer te verminderen, zodat wordt voldaan aan National Emission Ceilings Directive (NEC) van de EU en het Gothenborg Protocol van de Verenigde Naties. Daarnaast zijn ammoniakemissiebeperkende maatregelen in de landbouw nodig om de stikstofdepositie op Natura 2000-gebieden te beperken.

Ammoniakemissiebeperkende maatregelen die leiden tot minder stikstofaanvoer naar landbouwgronden, zoals minder stikstof in ruw- en krachtvoer en minder kunstmest, kunnen een bijdrage leveren aan het reduceren van nitraatuitspoeling. Maatregelen die leiden tot minder ammoniakemissie uit mest in stallen, mestopslagen en bij mesttoediening, waardoor er meer stikstof in de mest aanwezig is, kunnen het risico op nitraatuitspoeling vergroten indien bij de bemesting geen rekening wordt gehouden met het hogere stikstofgehalte in mest. In het bemestingsadvies voor grasland en voedergewas ${ }^{10}$ kan de werkingscoëfficiënt berekend worden op basis van de toedieningstechniek en -tijdstip. Bij de werkingscoëfficiënten die in het mestbeleid worden gehanteerd, wordt geen rekening gehouden met de mesttoedieningstechniek.

Bij alle diercategorieën neemt het aantal emissiearme huisvestingssystemen toe (Tabel 6). Bij melken kalfkoeien is de implementatie van emissiearme huisvestingssystemen het laagst (ongeveer $21 \%$ in 2018). Op grasland is de mesttoedieningstechniek sinds 2012 weinig veranderd. De meeste mest wordt toegediend met een zodenbemester (in sleufjes in de grond), gevolgd door toediening met een sleufkouter (deels in de grond en deels op de grond) en een sleepvoet (in strookjes op de grond). Sleepvoet wordt vooral op klei- en veengrond toegepast. Het risico op oppervlakkige afspoeling mest is waarschijnlijk groter bij sleepvoet (op de bodem) dan bij zodenbemesting (in de bodem). De ammoniakemissie is bij zodenbemesting het laagst (19\% van de ammoniakale $\mathrm{N}$ die is toegediend; Lagerwerf et al., 2019). Bij sleepvoet gaat er 32\% verloren door ammoniakemissie. Sinds 1 januari 2019 is het verplicht om mest te verdunnen bij toepassing van sleepvoet met minimaal 1 deel water per 2 delen mest; deze techniek heeft een emissiefactor vergelijkbaar met zodenbemesting (CDM, 2017a). De kanttekening die bij de implementatiegraad van emissiearme toedieningstechnieken valt te maken, is dat deze waarschijnlijk te optimistisch is, omdat deze gebaseerd is op wat de ondernemers opgeven. Daarnaast is het bekend dat 'slordig' werken de effectiviteit van de technieken niet ten goede komt. Bij het opstellen van de reservemaatregelen PAS wordt het 'netter' werken dan ook genoemd als belangrijke factor om emissies terug te dringen; een ruw ingeschatte reductie van $20 \%$ (Groenestein et al., 2019).

\footnotetext{
${ }^{10}$ Adviesbasis Commissie Bemesting Grasland en Voedergewassen: https://edepot.wur.nl/413891
} 
Tabel 6 Aandeel van verschillende huisvestingssystemen bij enkele diercategorieën (CDM, 2020d op basis CBS).

\begin{tabular}{|c|c|c|c|c|c|c|c|}
\hline & 2012 & 2013 & 2014 & 2015 & 2016 & 2017 & 2018 \\
\hline \multicolumn{8}{|l|}{ Melk- en kalfkoeien (drijfmest) } \\
\hline emissiearme ligboxenstal of loopstal & 7 & 7 & 7 & 17 & 19 & 20 & 20 \\
\hline overige huisvesting & 90 & 90 & 90 & 81 & 80 & 79 & 79 \\
\hline \multicolumn{8}{|l|}{ Fokzeugen inclusief biggen tot $25 \mathbf{~ k g}$} \\
\hline emissiearme stal & 57 & 69 & 71 & 75 & 75 & 82 & 82 \\
\hline \multicolumn{8}{|l|}{ Vlees- en opfokvarkens } \\
\hline reguliere stal & 45 & 31 & 29 & 27 & 22 & 22 & 19 \\
\hline emissiearme stal & 55 & 69 & 71 & 73 & 78 & 78 & 81 \\
\hline
\end{tabular}

Tabel 7 Aandeel van verschillende mesttoedieningstechnieken in procent van toegediende mest (CDM, 2020d op basis CBS).

\begin{tabular}{|c|c|c|c|c|c|c|c|}
\hline & 2012 & 2013 & 2014 & 2015 & 2016 & 2017 & 2018 \\
\hline \multicolumn{8}{|l|}{ Grasland - drijfmest } \\
\hline in sleufjes in de grond & 62 & 62 & 62 & 64 & 64 & 64 & 64 \\
\hline in strookjes op de grond & 14 & 14 & 14 & 13 & 13 & 13 & 13 \\
\hline bovengronds bemesten & 1 & 1 & 1 & 1 & 1 & 1 & 1 \\
\hline mestinjectie & 80 & 80 & 80 & 86 & 86 & 86 & 86 \\
\hline in sleufjes in de grond & 14 & 14 & 14 & 9 & 9 & 9 & 9 \\
\hline onderwerken in 1 werkgang & 6 & 6 & 6 & 5 & 5 & 5 & 5 \\
\hline bovengronds bemesten & 0 & 0 & 0 & 0 & 0 & 0 & 0 \\
\hline \multicolumn{8}{|l|}{ Beteeld bouwland - drijfmest } \\
\hline in sleufjes in de grond & 70 & 70 & 70 & 70 & 70 & 70 & 70 \\
\hline in strookjes op de grond & 30 & 30 & 30 & 30 & 30 & 30 & 30 \\
\hline
\end{tabular}

\subsection{Samenvatting}

De schaalvergroting neemt toe in de landbouw in de periode 2010-2019; het aantal bedrijven neemt af en het oppervlakte per bedrijf neemt toe bij de meeste bedrijfstypen. Uitspoelingsgevoelige gewassen zijn in 2006 afgeleid als gewassen waarvan de nitraatuitspoeling bij toepassing van de (toenmalige) landbouwkundige bemestingsadviezen leidt tot overschrijding van $50 \mathrm{mg}$ nitraat per $\mathrm{L}$ in het uitspoelende water. Tot de uitspoelingsgevoelige gewassen behoren de gewassen uit de groepen aardappelen, groenten en maïs. Er zijn geen grote veranderingen opgetreden in het areaal uitspoelingsgevoelige gewassen tussen 2010 en 2018. De opbrengsten van akkerbouwgewassen fluctueren de laatste jaren; het weer heeft een groot effect. In het droge jaar 2018 was de opbrengst bij veel gewassen en ook bij grasland relatief laag. Door de sterke fluctuaties tussen jaren is er geen duidelijk trend in opbrengst sinds 2010.

Het aantal landbouwdieren bepaalt de hoeveelheid mest die wordt geproduceerd, de toepassing van mest en mogelijk risico op nutriëntenuitspoeling. Het aantal melkkoeien is in de periode 2013-2017 sterk gestegen door het afschaffen van het melkquotumsysteem op 1 april 2015, daarna weer afgenomen door het invoeren van het fosfaatrechtensysteem en lag in 2019 op het niveau van 2014. 
Het aantal varkens is vrij stabiel gebleven in de periode 2010-2019, het aantal leghennen is iets gedaald en het aantal slachtkuikens iets gestegen. Het aantal geiten is bijna verdubbeld in de periode 2010-2019. In 2010 werd 74\% van de koeien beweid en in 2016 65\%. In 2017 en 2018 is weidegang weer iets toegenomen tot $71 \%$ in 2018 .

Ammoniakemissiebeperkende maatregelen kunnen een effect hebben op de nitraatuitspoeling, omdat deze maatregelen de hoeveelheid stikstof die met mest wordt toegediend, beïnvloeden. Bij alle diercategorieën is het aantal emissiearme huisvestingssystemen toegenomen sinds 2010. In de laatste jaren zijn weinig veranderingen opgetreden in de mesttoedieningstechnieken die gebruikt worden. Bij de werkingscoëfficiënten die in het mestbeleid worden gehanteerd, wordt geen rekening gehouden met de mesttoedieningstechniek. 


\section{$5 \quad$ Trends in mestproductie en gebruik van meststoffen}

\section{$5.1 \quad$ Mestproductie}

De hoeveelheid mest die wordt geproduceerd en de toepassing van mest zijn beide van invloed op de uitspoeling van nutriënten. In Tabel 8 wordt de mestproductie in $\mathrm{kg}$ stikstof per dier en $\mathrm{kg}$ fosfaat per dier gegeven. De stikstofexcretie per melkkoe is sterk gestegen. De belangrijkste factoren hierbij zijn (CDM, 2010d) het stijgen van de melkproductie (paragraaf 4.3.2), het lichaamsgewicht per koe en de toename van het stikstofgehalte in het ruwvoer. De stijging van het stikstofgehalte in het ruwvoer wordt veroorzaakt door een combinatie van veranderingen in stikstofgehalte van gras en snijmaïs (Tabel 3), grotendeels bepaald door weersinvloeden en groeiomstandigheden en veranderingen in de aandelen van snijmaïs en gras in het ruwvoer. In 2014 is in het kader van een derogatie als eis gesteld dat het graslandareaal minimaal $80 \%$ moet zijn op een graasveebedrijf (in plaats van $70 \%$ die daarvoor gold). Ook de relatief lagere opbrengsten door droogte hebben een rol gespeeld in de veranderingen van het rantsoen (). De stikstofexcretie van varkens en vleeskuikens is iets gedaald.

De fosfaatexcretie van vleesvarkens en vleeskuikens is duidelijk afgenomen. Die van melkvee en vrouwelijk jongvee heeft ook een dalende trend, maar er zijn grotere variaties tussen jaren (waarschijnlijk door weerseffecten op het fosforgehalte van ruwvoer). Op fosfaat is via het voerspoor de laatste jaren sterk gestuurd in verband met overschrijding van het fosfaatplafond en invoering van fosfaatrechten in de melkveesector. Daardoor is de fosfaatexcretie - in tegenstelling tot de stikstofexcretie - niet toegenomen in de laatste jaren.

Tabel $8 \quad$ Mestproductie per dier in $\mathrm{kg} \mathrm{N}$ per dier (bruto-excretie, zonder correctie voor gasvormige $\mathrm{N}$-verliezen in stallen en opslagen) en in $\mathrm{kg} \mathrm{P}_{2} \mathrm{O}_{5}$ per dier (Bron: $\mathrm{CBS}$ ).

\begin{tabular}{lrrrrrrrrrr} 
& 2010 & 2011 & 2012 & 2013 & 2014 & 2015 & 2016 & 2017 & 2018 & 2019 \\
N-excretie, kg per dier & & & & & & & & & \\
\hline vrouwelijk jongvee, $1-2$ j & 73,2 & 71,2 & 69,6 & 70,9 & 73,1 & 69,7 & 68,9 & 69,3 & 72,9 & 71,9 \\
\hline melk- en kalfkoeien & 130,2 & 127,6 & 122,3 & 123,3 & 128,4 & 130,4 & 130,1 & 144,0 & 147,1 & 145,7 \\
\hline vleesvarkens & 12,2 & 12,5 & 12,5 & 12 & 11,9 & 11,6 & 11,5 & 11,7 & 11,7 & 11,5 \\
\hline zeugen & 30,2 & 30,1 & 29,6 & 31,1 & 29,1 & 29,5 & 29,7 & 30,2 & 30,2 & 29,9 \\
\hline Leghennen > 18 weken & 0,80 & 0,78 & 0,76 & 0,77 & 0,75 & 0,75 & 0,75 & 0,76 & 0,78 & 0,82 \\
\hline vleeskuikens & 0,50 & 0,52 & 0,48 & 0,49 & 0,44 & 0,43 & 0,43 & 0,4 & 0,41 & 0,41 \\
\hline P O -excretie, kg per dier & & & & & & & & & & \\
\hline vrouwelijk jongvee, 1-2 j & 22,1 & 21,5 & 22,2 & 21,9 & 23,1 & 23,5 & 21,4 & 20,1 & 19,6 & 18,7 \\
\hline melk- en kalfkoeien & 43 & 40,6 & 38,4 & 39,2 & 40,6 & 43,1 & 39,9 & 41,4 & 40,4 & 39,9 \\
\hline vleesvarkens & 4,9 & 4,7 & 4,3 & 4,2 & 4,2 & 4,3 & 4,3 & 4,2 & 4,2 & 4,2 \\
\hline zeugen & 15,1 & 14,6 & 13,3 & 14,6 & 14 & 14 & 14,2 & 13,3 & 13,8 & 13,6 \\
\hline Leghennen > 18 weken & 0,41 & 0,4 & 0,4 & 0,4 & 0,4 & 0,4 & 0,41 & 0,42 & 0,42 & 0,43 \\
\hline vleeskuikens & 0,17 & 0,18 & 0,15 & 0,16 & 0,15 & 0,14 & 0,14 & 0,13 & 0,12 & 0,12 \\
\hline
\end{tabular}

In Figuur 11 staat de totale mestproductie in Nederland in de periode 2010-2019 weergegeven, uitgedrukt in stikstof en fosfaat. De stikstofproductie is toegenomen in de periode 2012-2017 door de toename van het aantal koeien (Tabel 4) en door een toename van de stikstofexcretie per koe (Tabel 8). In 2018 en 2019 is de totale stikstofproductie iets gedaald door een daling van het aantal koeien (Tabel 4). De totale stikstofproductie in mest is in 2019 gelijk aan die van 2010. De fosfaatproductie is ook gestegen in de periode 2012-2015, maar is daarna afgenomen door een daling van het aantal koeien en daling/stabilisatie van de fosfaatexcretie per koe. De fosfaatproductie door varkens en pluimvee is iets gedaald. De fosfaatproductie in 2019 is 13\% lager dan in 2010. 
In het kader van de derogatie moet de mestproductie uitgedrukt in stikstof en fosfaat in Nederland onder het niveau van 2002 blijven; de stikstof- en fosfaatplafonds. Het stikstofplafond bedraagt 504,4 miljoen kg stikstof. In 2017 is het stikstofplafond overschreden en in 2016 en 2018 lag de stikstof-productie net onder het plafond. Het fosfaatplafond bedraagt 172,9 miljoen $\mathrm{kg} \mathrm{P}_{2} \mathrm{O}_{5}$. Dit plafond is in 2010, 2015 en 2016 overschreden, maar na 2016 lag de mestproductie onder het plafond.
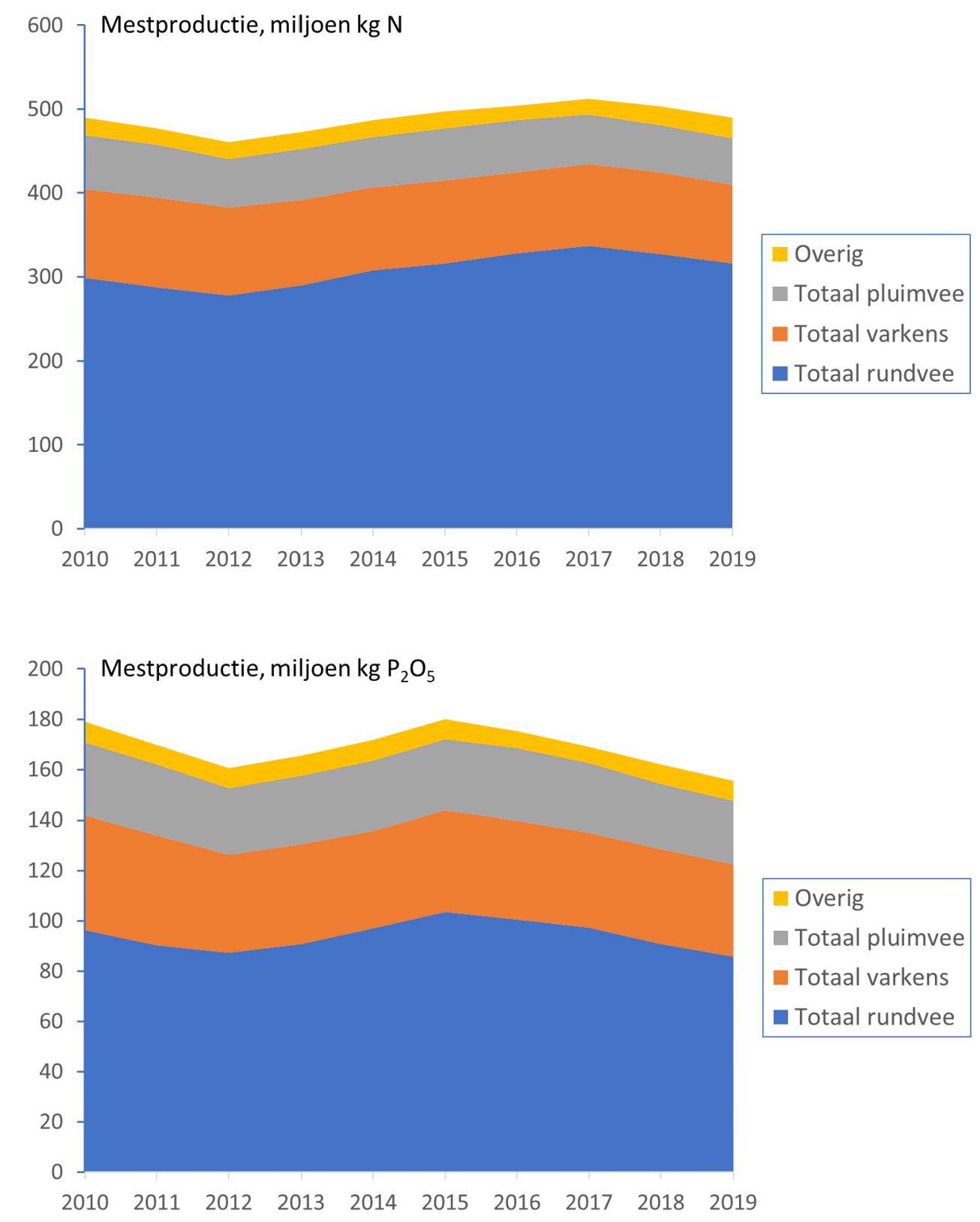

Figuur 11 Mestproductie in $\mathrm{kg} \mathrm{N}$ (bovenste figuur) en $\mathrm{kg} \mathrm{P}_{2} \mathrm{O}_{5}$ (onderste figuur).

\subsection{Ontwikkeling mestmarkt en mestverwerking}

\subsubsection{Afzet buiten de Nederlandse landbouw}

De plaatsingsruimte voor dierlijke mest is in de periode 2010-2019 afgenomen en de export en mestverwerking zijn in deze periode toegenomen, zowel uitgedrukt in stikstof als fosfaat (Tabel 9). Het gebruik van dierlijke mest uitgedrukt in stikstof is toegenomen en die uitgedrukt in fosfaat is afgenomen (Tabel 9). Bij de mestafzet buiten de Nederlandse landbouw wordt onderscheid gemaakt tussen het gebruik van mest op niet-landbouwgronden (grond van hobbybedrijven en particulieren en 
natuurterreinen), mestverbranding en mestexport. ${ }^{11}$ De hoeveelheid mest die buiten de Nederlandse landbouw wordt afgezet, is in de periode 2010-2016 gestegen en daalt daarna weer (Tabel 10). De toename van de mestproductie door melkvee is een belangrijke oorzaak voor de sterke toename van mestafzet buiten de Nederlandse landbouw in de periode 2015-2017. Rundveemest wordt meestal binnen Nederland afgezet, terwijl pluimveemest verwerkt wordt door mestverbranding of door de productie van droge mestkorrels. Varkensmest werd in deze periode deels geëxporteerd naar Duitsland, België en Frankrijk (Figuur 12).

De bij RVO geregistreerde mestverwerkingsovereenkomsten laten zien dat in 2018 voor in totaal 40,6 miljoen $\mathrm{kg}$ fosfaat geregistreerd is als verwerking en export in het kader van de verplichte Mestverwerking (NCM, 2019). Pluimveemestverbranding bedraagt per jaar 8,7 miljoen kg fosfaat (NCM, 2019). De meeste mest wordt geëxporteerd naar Duitsland, België en Frankrijk (Figuur 13). In 2017 en 2018 is de mestexport naar Duitsland gedaald, terwijl de export naar België en Frankrijk iets toenam. De afname van mestexport naar Duitsland wordt met name veroorzaakt door een afname in export van niet-gehygiëniseerde pluimveemest en gehygiëniseerde varkensmest (Figuur 12). Nietgehygiëniseerde mest wordt vooral afgezet in België en Duitsland (Figuur 12). Naar Frankrijk wordt vrijwel alleen maar verwerkte varkens- en pluimveemest geëxporteerd. De afzet van mestkorrels vindt voor $25 \%$ plaats binnen de EU en voor $75 \%$ daarbuiten. De NCM (2019) concludeert dat de gerealiseerde verwerking/export van mest vanaf de inwerkingtreding van de verplichte mestverwerking in 2014 steeds voldoende is geweest om het totale fosfaatoverschot te verwerken of te exporteren. In totaal is in 2018 via mineralenconcentraat circa $2 \mathrm{mln}$. $\mathrm{kg}$ stikstof verwerkt en afgezet als bemestings-product boven de gebruiksnorm voor dierlijke mest (NCM, 2019).

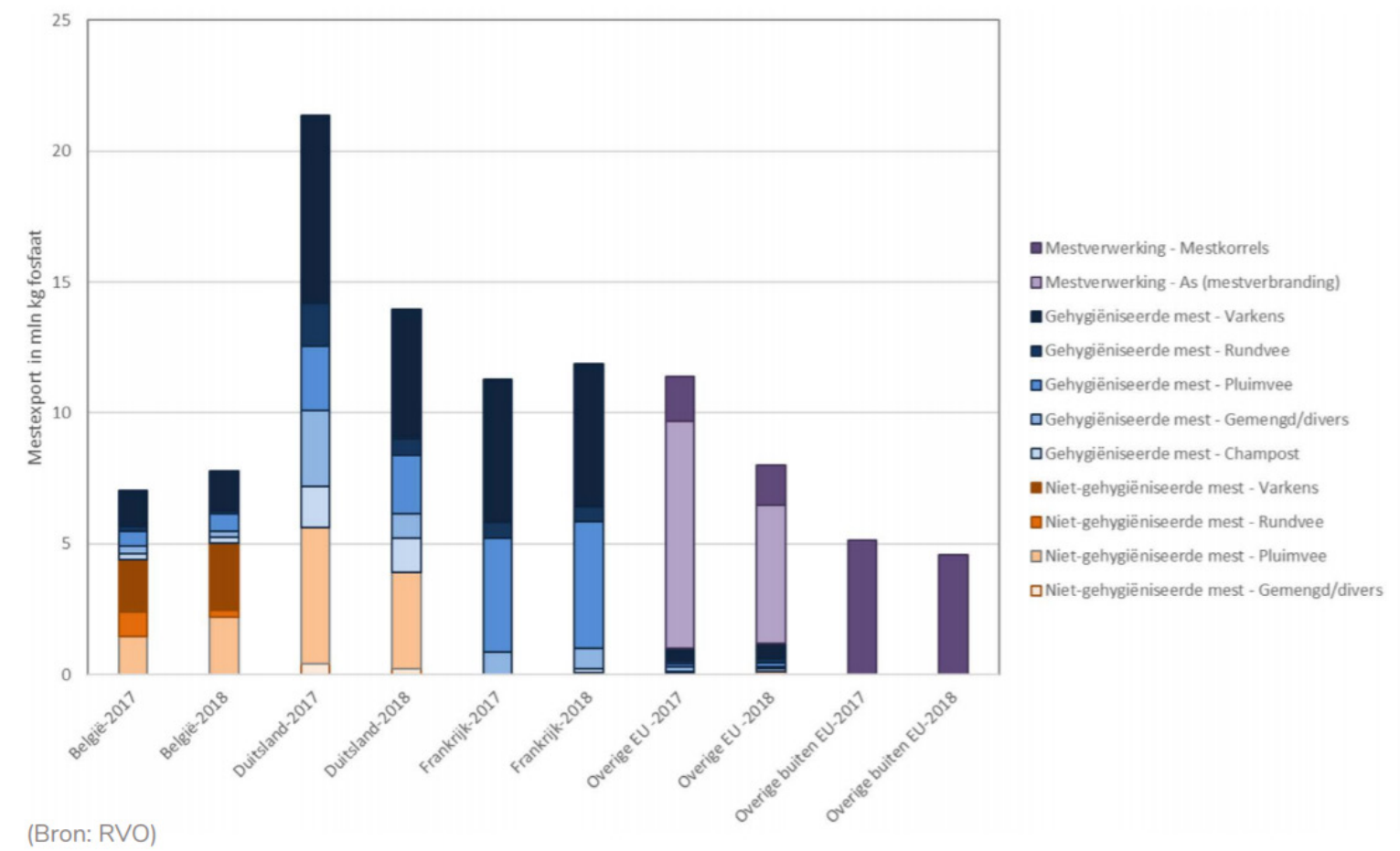

Figuur 12 Mestexport per land per jaar naar hygiënisatie en diersoort in mln. kg fosfaat per jaar (NCM, 2019).

\footnotetext{
${ }^{11}$ De Meststoffenwet en de Uitvoeringsregeling Meststoffenwet verstaat onder dierlijke meststoffen verwerken (Rijksoverheid, 2016a\&b) het behandelen van dierlijke meststoffen tot een eindproduct dat voldoet aan de volgende specificaties, i) as waarin maximaal $10 \%$ organische stof aanwezig is, ii) mestkorrels, iii) mengsel van gedroogd digestaat en verwerkt categorie 1-materiaal, als bedoeld in artikel 8 van verordening (EG) nr. 1069/2009 en iv) het exporteren van dierlijke meststoffen.
} 


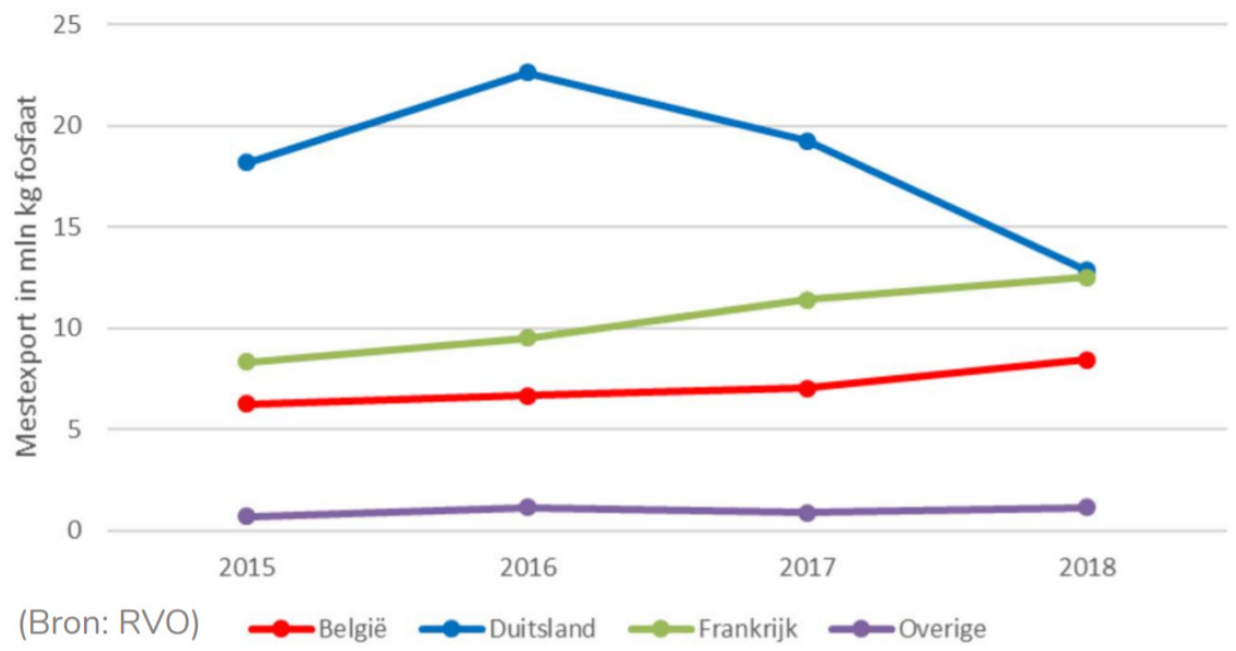

Figuur 13 Export dierlijke mest per land per jaar (in mln. $\mathrm{kg}$ fosfaat) (m.u.v. mestkorrels en as) (NCM, 2019).

Tabel 9 Productie en gebruik van dierlijke mest (Bron: CBS).

\begin{tabular}{|c|c|c|c|c|c|c|c|c|c|c|}
\hline & \multicolumn{10}{|c|}{ Miljoen kg N } \\
\hline Totaal uitscheiding & 490 & 477 & 461 & 473 & 487 & 497 & 504 & 512 & 504 & 490 \\
\hline Uitscheiding in de wei & 74 & 62 & 57 & 61 & 61 & 57 & 51 & 52 & 51 & 51 \\
\hline Stikstofverliezen in stal en opslag & 65 & 64 & 61 & 59 & 62 & 63 & 63 & 64 & 64 & 62 \\
\hline Van landbouwbedrijven afgevoerde mest & 154 & 163 & 165 & 164 & 164 & 181 & 177 & 187 & 175 & \\
\hline Op landbouwbedrijven aangevoerde mest & 84 & 98 & 96 & 93 & 89 & 96 & 90 & 101 & 96 & \\
\hline Verwerkte mest (exclusief export) & 20 & 19 & 21 & 22 & 21 & 21 & 20 & 20 & 17 & \\
\hline \multirow{2}{*}{ Gebruik dierlijke mest in de landbouw } & \multicolumn{10}{|c|}{ Miljoen $\mathrm{kg} \mathrm{P}_{2} \mathrm{O}_{5}$} \\
\hline & 2010 & 2011 & 2012 & 2013 & 2014 & 2015 & 2016 & 2017 & 2018 & 2019 \\
\hline Totaal uitscheiding & 179 & 170 & 161 & 166 & 172 & 180 & 175 & 169 & 162 & 156 \\
\hline Uitscheiding in de stal & 155 & 150 & 142 & 147 & 152 & 159 & 159 & 154 & 147 & 142 \\
\hline Uitscheiding in de wei & 23 & 20 & 19 & 19 & 20 & 21 & 16 & 15 & 15 & 14 \\
\hline Opgeslagen mest en weidemest & 179 & 170 & 161 & 166 & 172 & 180 & 175 & 169 & 162 & 156 \\
\hline Van landbouwbedrijven afgevoerde mest & 80 & 82 & 79 & 79 & 79 & 88 & 85 & 86 & 79 & \\
\hline
\end{tabular}


Tabel 10 Mestafzet buiten de Nederlandse landbouw (Bron: CBS).

\begin{tabular}{|c|c|c|c|c|c|c|}
\hline & Jaar & Mestexport & $\begin{array}{l}\text { Hobbybedrijven } \\
\text { en particulieren }\end{array}$ & Natuurterreinen & Mestverwerking & Totaal \\
\hline \multirow[t]{7}{*}{ Stikstof $(\mathrm{N})$, miljoen kg } & 2010 & 37,5 & 10,8 & 2,9 & 19,8 & 71,0 \\
\hline & 2012 & 36,1 & 12,9 & 3,3 & 21,3 & 73,7 \\
\hline & 2013 & 37,4 & 14,1 & 3,5 & 21,5 & 76,5 \\
\hline & 2015 & 47,7 & 12,5 & 3,3 & 21,4 & 84,9 \\
\hline & 2016 & 51,5 & 12,7 & 3,8 & 19,9 & 88,0 \\
\hline & 2017 & 48,7 & 9,0 & 4,1 & 19,6 & 81,4 \\
\hline & 2018 & 46,6 & 8,2 & 3,9 & $17,1^{*}$ & 75,8 \\
\hline \multirow{6}{*}{ Fosfaat $\left(\mathrm{P}_{2} \mathrm{O}_{5}\right)$, miljoen $\mathrm{kg}$} & 2013 & 21,1 & 6,1 & 1,2 & 10,0 & 38,3 \\
\hline & 2014 & 24,1 & 5,3 & 1,2 & 9,7 & 40,3 \\
\hline & 2015 & 28,7 & 5,3 & 1,2 & 9,7 & 45,0 \\
\hline & 2016 & 32,5 & 5,2 & 1,3 & 9,0 & 48,0 \\
\hline & 2017 & 31,1 & 3,6 & 1,3 & 8,6 & 44,7 \\
\hline & 2018 & 30,0 & 3,2 & 1,1 & $6,7^{*}$ & 41,1 \\
\hline
\end{tabular}

* mestverwerking is in 2018 iets lager dan in eerdere jaren door onderhoud aan pluimveemest- en verbrandingsinstallatie BMC Moerdijk.

\subsubsection{Mestafzetprijzen}

De mestafzetprijzen voor zowel rundvee- als varkensdrijfmest zijn in de periode 2014-2016 sterk gestegen, maar zijn in 2017 en 2018 gestabiliseerd (Bron: agrimatie.nl; Figuur 14). De daling van de mestafzetprijzen van pluimveemest in recente jaren wordt veroorzaakt door lagere prijzen voor afzet aan BMC Moerdijk. Pluimveehouders die hun droge mest aan korrelaars leveren, krijgen geld toe (Bron: Agrimatie.nl). De prijzen voor de afzet van varkens- en rundermest zijn gestegen in de periode 2014-2016 door toename van de mestproductie door melkvee (paragraaf 5.1). Er is hierdoor meer druk op de mestmarkt ontstaan, waardoor er meer mest verwerkt en geëxporteerd moest worden.

Prijzen van verkochte mest, euro per ton (exclusief BTW)

Per mestsoort

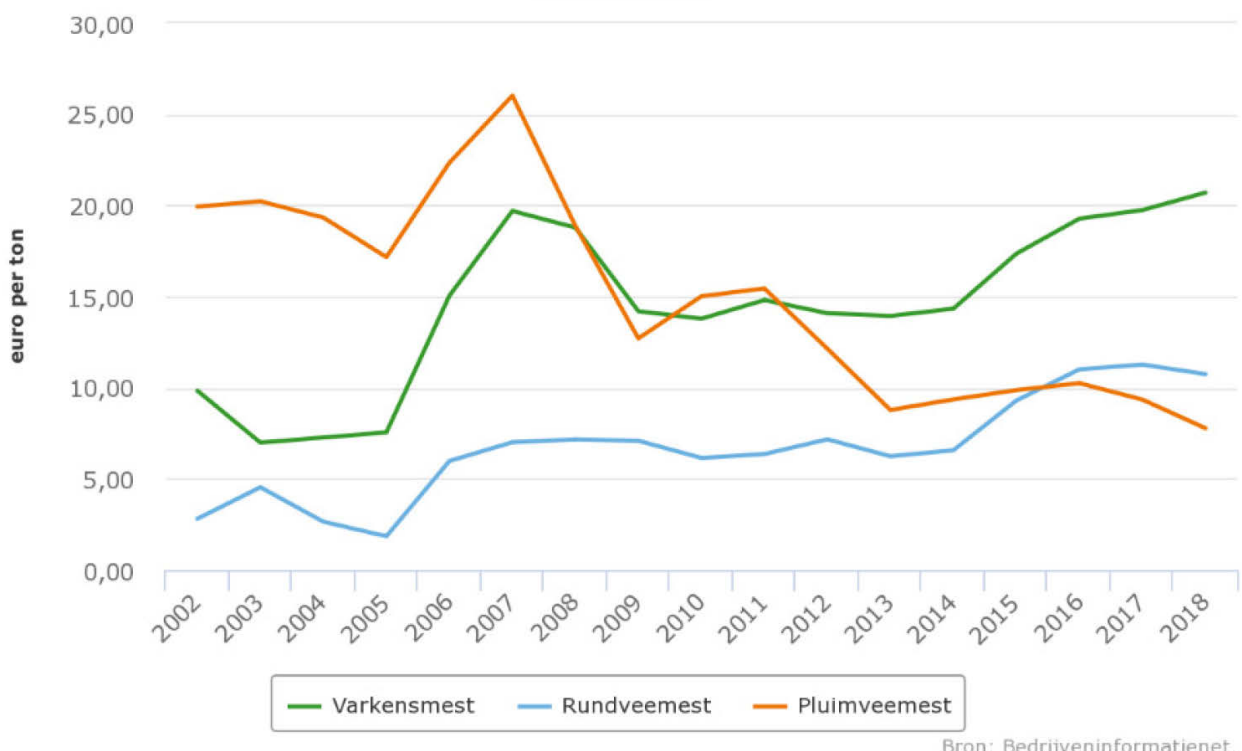

Figuur 14 Mestafzetprijzen (Bron: WEcR, Agrimatie.nI). 


\subsection{Meststoffengebruik}

\subsubsection{Melkveebedrijven}

\subsubsection{Stikstof}

De totale stikstofbemesting als kunstmest en werkzame stikstof in dierlijke mest op grasland schommelt tussen de jaren, maar er is geen duidelijke trend zichtbaar (Figuur 15). De stikstofbemesting op kleigrond is iets toegenomen vanaf 2014. Per 1 januari 2014 zijn de stikstofnormen voor grasland op kleigrond met $35 \mathrm{~kg} \mathrm{~N}$ verhoogd van 310 naar $345 \mathrm{~kg} \mathrm{~N}$ per ha per jaar voor grasland met beweiden, en van $350 \mathrm{~kg} \mathrm{~N}$ per ha per jaar naar $385 \mathrm{~kg} N$ per ha per jaar voor grasland met 100\% maaien. De bemesting met kunstmest en dierlijke mest in 2018 is in de meeste grondsoortregio's relatief laag. Dat wordt waarschijnlijk veroorzaakt door de droge zomer, waardoor er vaak een gras-snede minder is bemest en geoogst.

De verhouding tussen de hoeveelheid dierlijke mest en de hoeveelheid kunstmest die op melkveehouderijen wordt gebruikt, is sinds de invoering van het gebruiksnormenstelsel in 2006 weinig veranderd (Figuur 16). Dit geldt voor alle grondsoortregio's (niet getoond). Melkveebedrijven in de kleiregio hebben gemiddeld genomen het hoogste stikstofgebruik uit kunstmest ( $143 \mathrm{~kg} \mathrm{~N}$ per ha in 2018). De melkveebedrijven in de zand- en veenregio gebruiken de laatste jaren rond $110 \mathrm{~kg}$ stikstof uit kunstmest per ha. Op melkveebedrijven met een derogatie wordt de gebruiksnorm werkzame $\mathrm{N}$ de laatste jaren bijna volledig opgevuld; alleen in 2018 is er duidelijk minder stikstof gebruikt dan de gebruiks-norm (Figuur 17). Ook de gebruiksnorm dierlijke mest wordt op bedrijven met een derogatie vrijwel volledig benut.

Stikstofbemesting op grasland op melkveebedrijven naar regio

400

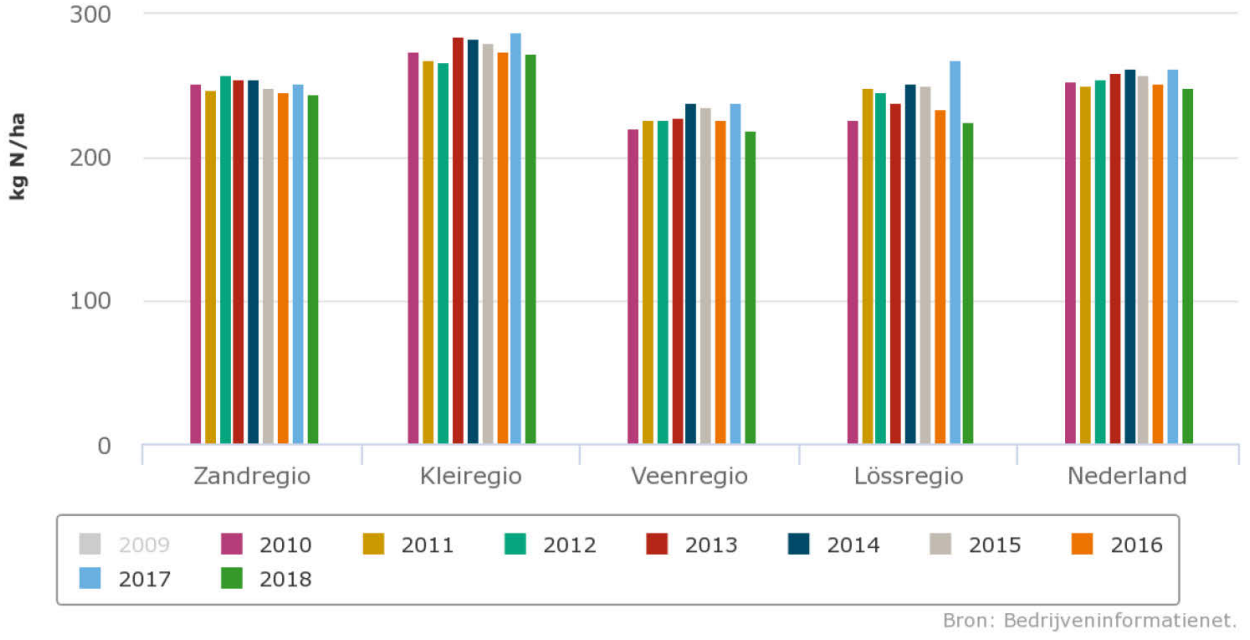

Figuur 15 Stikstofbemesting als werkzame $N$ (kunstmest en werkzame $N$ in dierlijke mest) op grasland in verschillende grondsoortregio's in de periode 2010-2018 (Bron: WECR, Agrimatie.nl). 
800

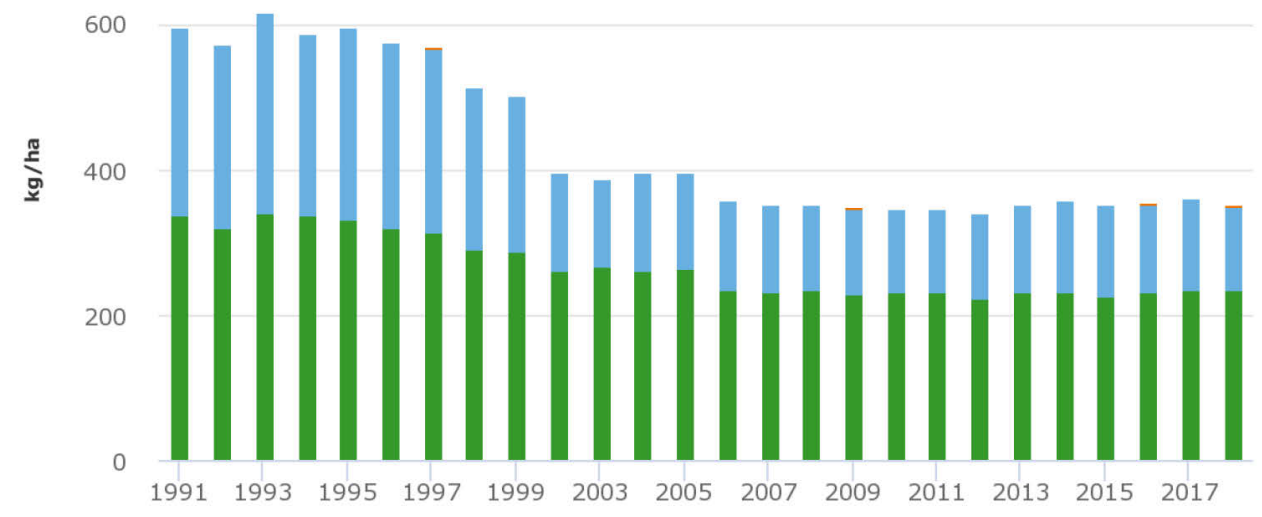

Dierlijke mest $\square$ Kunstmest $\square$ Overige organische mest

Bron: Bedrijveninformatienet.

Figuur 16 Stikstofbemesting als kunstmest, dierlijke mest en organische meststoffen op melkveebedrijven in Nederland in de periode 1991-2018 (Bron: WEcR, Agrimatie.nl).

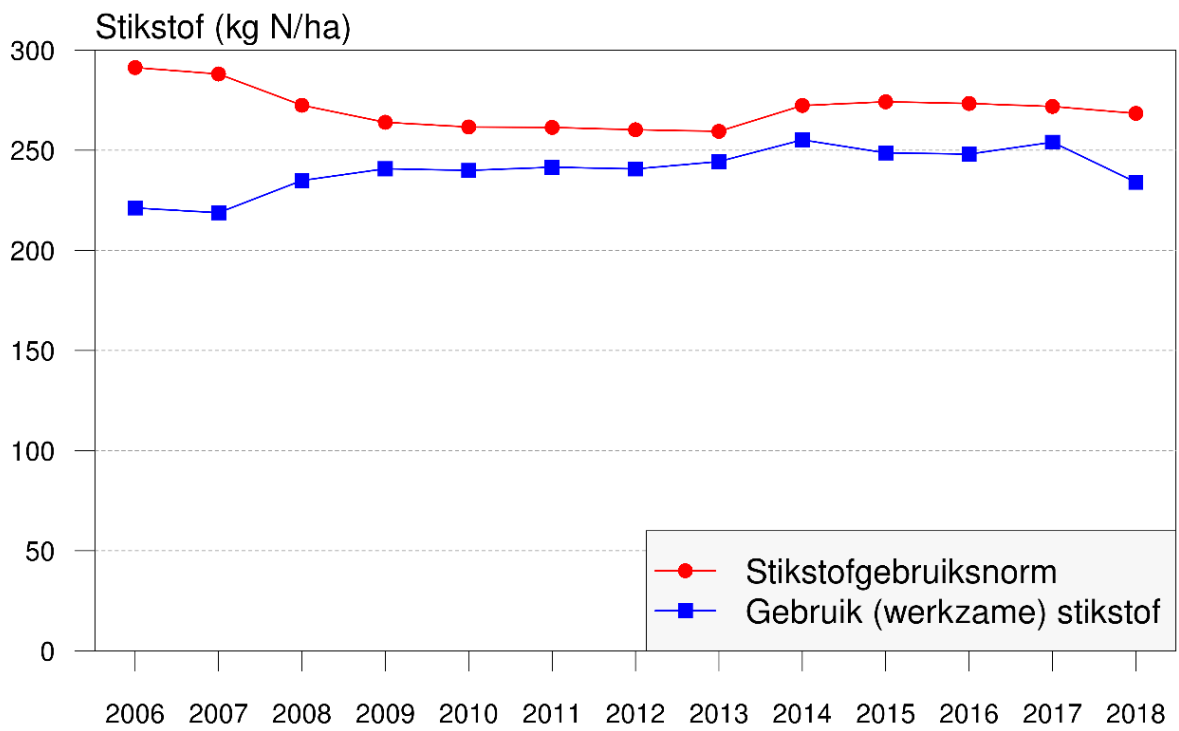

Figuur 17 Het gebruik van werkzame stikstof via dierlijke mest en kunstmest ( $\mathrm{kg} \mathrm{N} / \mathrm{ha}$ ) en de stikstofgebruiksnorm ( $\mathrm{kg} \mathrm{N} / \mathrm{ha}$ ) op bedrijven met derogatie in de periode 2006-2018 (Lukács et al., 2020).

\subsubsection{Fosfaat}

De fosfaatbemesting op melkveebedrijven neemt sterk af, op alle grondsoorten (Figuur 18). Dit wordt voor een belangrijk deel veroorzaakt doordat er amper nog fosfaatkunstmest wordt gebruikt op melkveebedrijven (Figuur 19); op melkveebedrijven met een derogatie is het namelijk verboden om dit te gebruiken. Daarnaast neemt ook de hoeveelheid fosfaat die met dierlijke mest wordt toegediend iets af (Figuur 19). Dit wordt deels veroorzaakt doordat de fosfaatgebruiksnorm is aangescherpt in 2015 voor grasland bij een fosfaattoestand neutraal en hoog, waardoor de fosfaatgebruiksruimte is gedaald (zie Figuur 20 voor derogatiebedrijven). De laatste jaren is sterk gestuurd op een lage fosfaatexcretie om onder het fosfaatplafond te blijven; dit heeft waarschijnlijk geleid tot een daling in de fosfaatgehalten in mest. De fosfaatgebruiksruimte wordt op bedrijven met een derogatie bijna volledig benut (Figuur 20). 
Fosfaatbemesting op melkveebedrijven naar regio

100,0

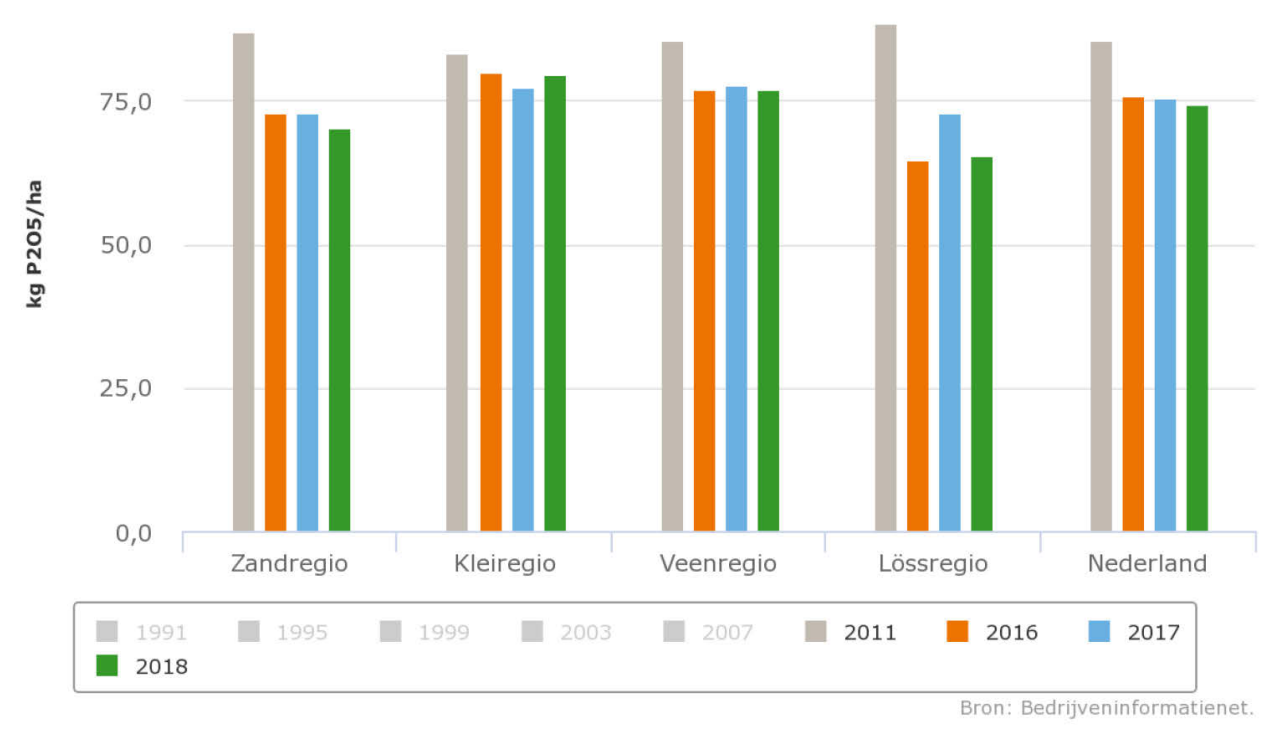

Figuur 18 Fosfaatbemesting op melkveebedrijven in verschillende grondsoortregio's in 2011, 2016, 2017 en 2018 (Bron: WECR, Agrimatie.nI).

Fosfaatbemesting op melkveebedrijven

Nederland

200,0

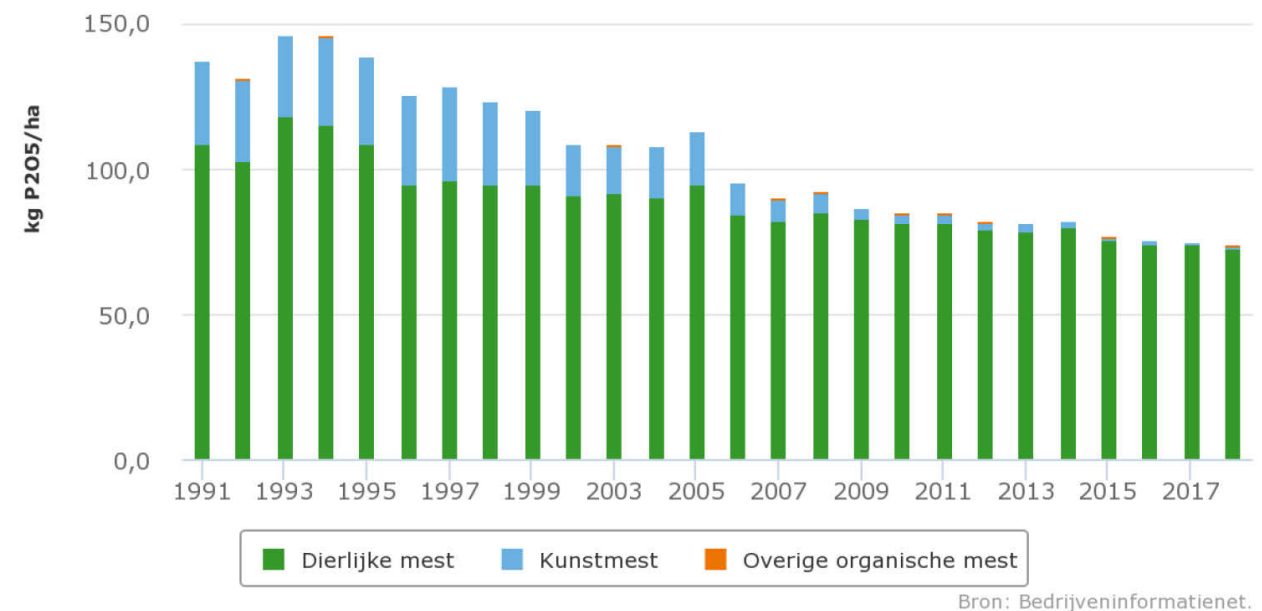

Figuur 19 Fosfaatbemesting als kunstmest, dierlijke mest en organische meststoffen op melkveebedrijven in verschillende grondsoortregio's in de periode 1991-2018 (Bron: WEcR, Agrimatie.nI). 


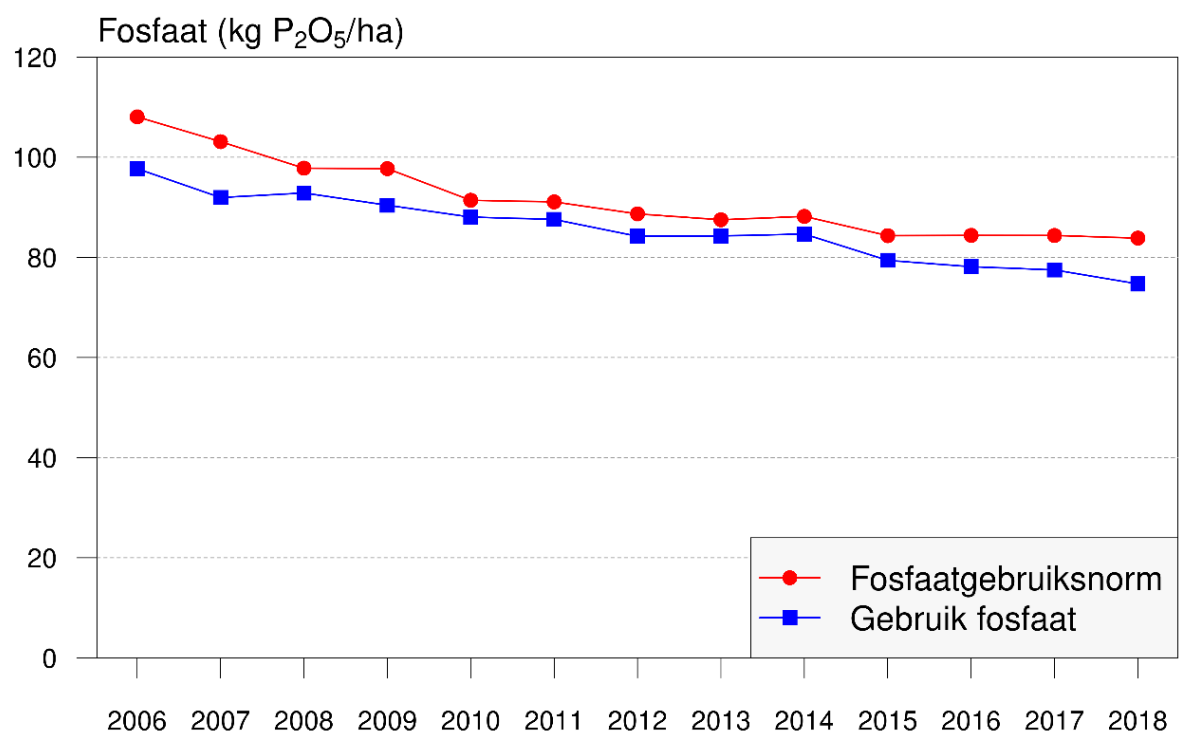

Figuur 20 Het gebruik van fosfaat via dierlijke mest en kunstmest ( $k g \mathrm{P}_{2} \mathrm{O}_{5} / \mathrm{ha}$ ) en de fosfaatgebruiksnorm ( $k g \mathrm{P}_{2} \mathrm{O}_{5} / \mathrm{ha}$ ) op bedrijven met derogatie in de periode 2006-2018 (Lukács et al., 2020).

\subsubsection{Akkerbouwbedrijven}

\subsubsection{Stikstof}

De stikstofbemesting op akkerbouwbedrijven op zand- en lössgrond is de laatste jaren gedaald, terwijl die van kleigrond is gestegen (Figuur 21). In 2015 zijn de stikstofgebruiksnormen voor uitspoelingsgevoelige gewassen in het zuidelijk zand- en lössgebied met $20 \%$ verlaagd. Uitspoelingsgevoelige gewassen zijn onder andere aardappelen, suikerbieten, snijmaïs en een groot aantal groentegewassen. Sinds 2010 mogen ondernemers op kleigrond met een bovengemiddelde hectareopbrengst van frites-aardappelen en suikerbieten voor die gewassen een hogere stikstofnorm toepassen. Deze voorziening is in het $5^{\text {e }}$ Actieprogramma Nitraatrichtlijn (vanaf 2014) uitgebreid naar de teelt van granen. De extra stikstofnorm per ha per jaar voor bedrijven die gebruikmaken van stikstofdifferentiatie bedraagt $15 \mathrm{~kg} \mathrm{~N}$ per ha voor suikerbieten, $30 \mathrm{~kg} \mathrm{~N}$ per ha voor fritesaardappelen, $15 \mathrm{~kg} \mathrm{~N}$ per ha voor wintertarwe en $20 \mathrm{~kg} \mathrm{~N}$ per ha voor zomertarwe en wintergerst. Waarschijnlijk is de mogelijkheid tot stikstofdifferentiatie de reden voor de hogere stikstofbemesting op kleigrond in de periode 2016-2018 ten opzichte van 2011.

Het aandeel kunstmest in de stikstofbemesting is afgenomen en het aandeel overige organische meststoffen, zoals compost, is beperkt, maar neemt wel iets toe (Figuur 22). In 2018 was de gemiddelde stikstofgift met dierlijke mest op bedrijven van het Landelijk Meetnet Effecten Mestbeleid (LMM) $82 \mathrm{~kg} \mathrm{~N}$ per ha voor kleiregio, $110 \mathrm{~kg} \mathrm{~N}$ per ha in de lössregio en $112 \mathrm{~kg} \mathrm{~N}$ per ha in de zandregio (Bron: Agrimatie. $\mathrm{nl}$ ). Dit geeft aan dat de stikstofgebruiksnorm dierlijke mest (170 kg N per ha) niet wordt opgevuld op deze akkerbouwbedrijven. Het verschil in gebruik van dierlijke mest op akkerbouwbedrijven in de verschillende grondsoortregio's heeft te maken met verschillen tussen de regio's in de aanwezigheid van veehouderijen. 


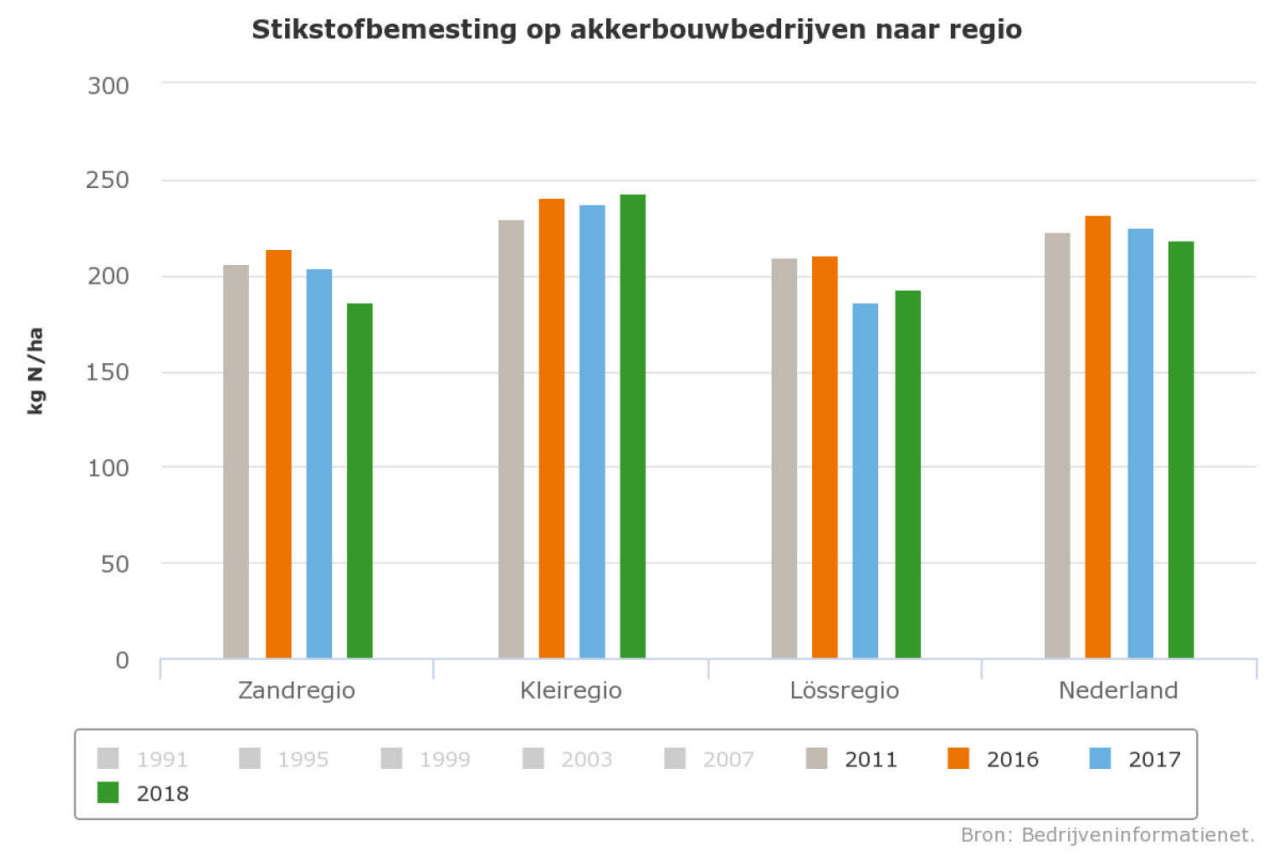

Figuur 21 Stikstofbemesting op akkerbouwbedrijven in verschillende grondsoortregio's in 2011, 2016, 2017 en 2018 (Bron: WEcR, Agrimatie.nl).

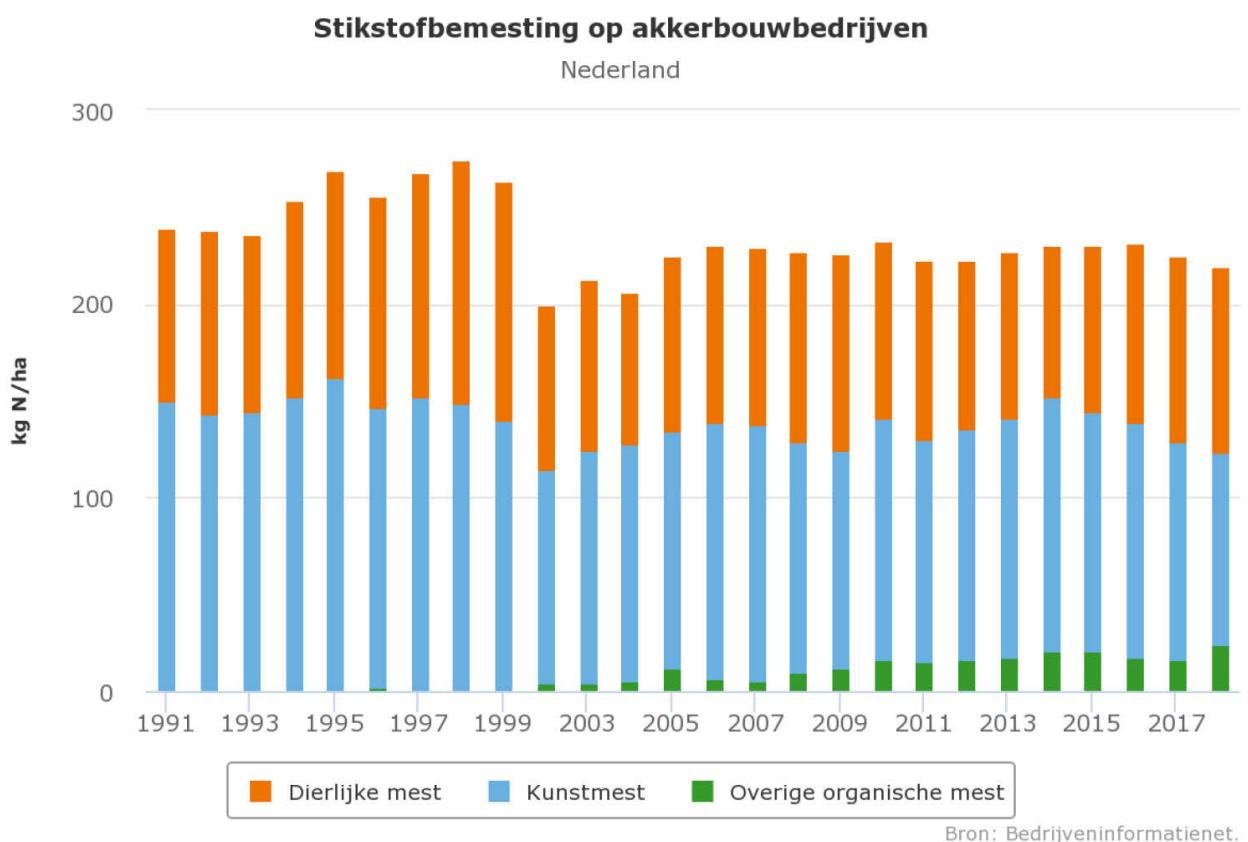

Figuur 22 Stikstofbemesting als kunstmest, dierlijke mest en organische meststoffen op akkerbouwbedrijven in de periode 1991-2018 (Bron: WEcR, Agrimatie.nl).

\subsubsection{Fosfaat}

De fosfaatbemesting op akkerbouwbedrijven is sterk gedaald sinds de introductie van het gebruiksnormenstelsel in 2006, maar de laatste jaren zijn er weinig veranderingen opgetreden (Figuur 23; Figuur 24). Zowel het gebruik van kunstmest als dierlijke mest is gedaald, terwijl het gebruik van de hoeveelheid overige organische meststoffen is gestegen. 


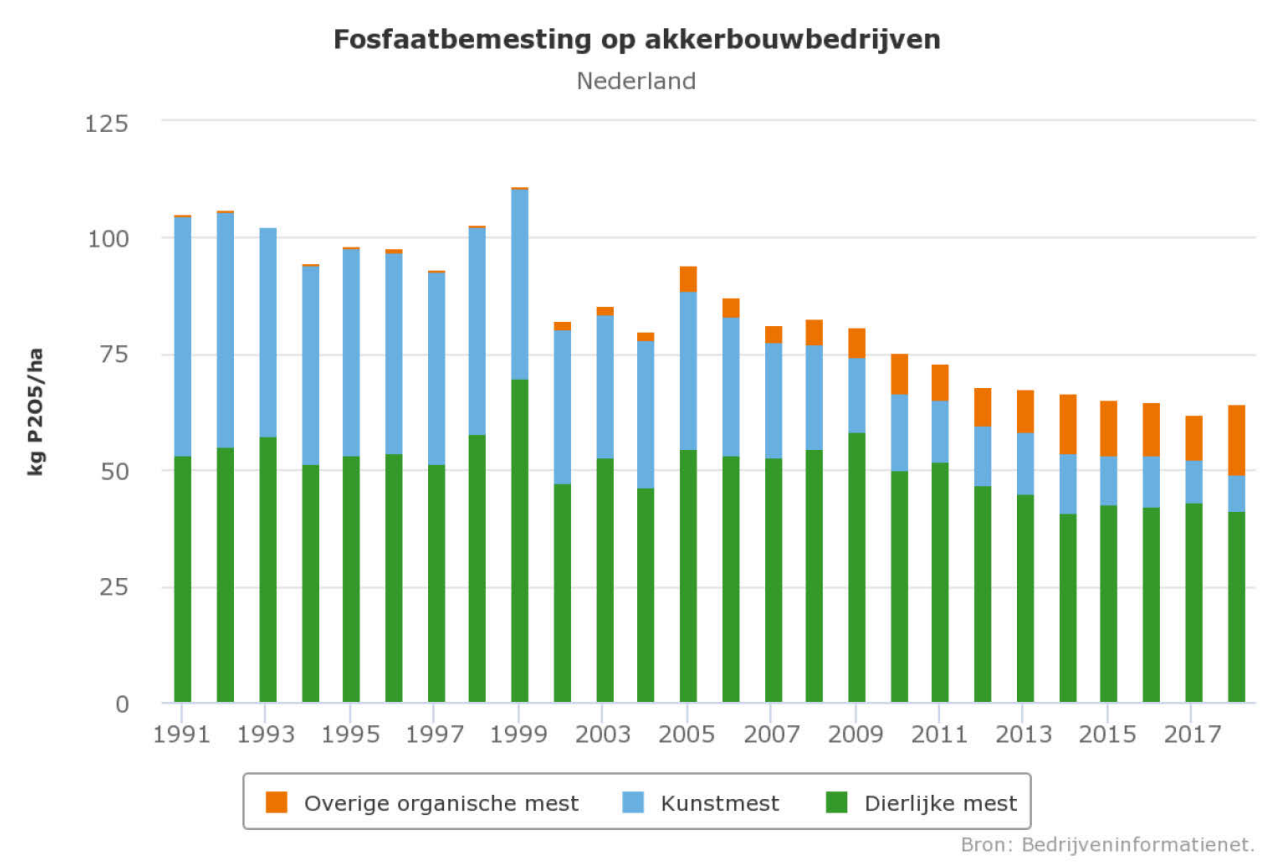

Figuur 23 Fosfaatbemesting als kunstmest, dierlijke mest en organische meststoffen op akkerbouwbedrijven in de periode 1991-2018 (Bron: WECR, Agrimatie.nI).

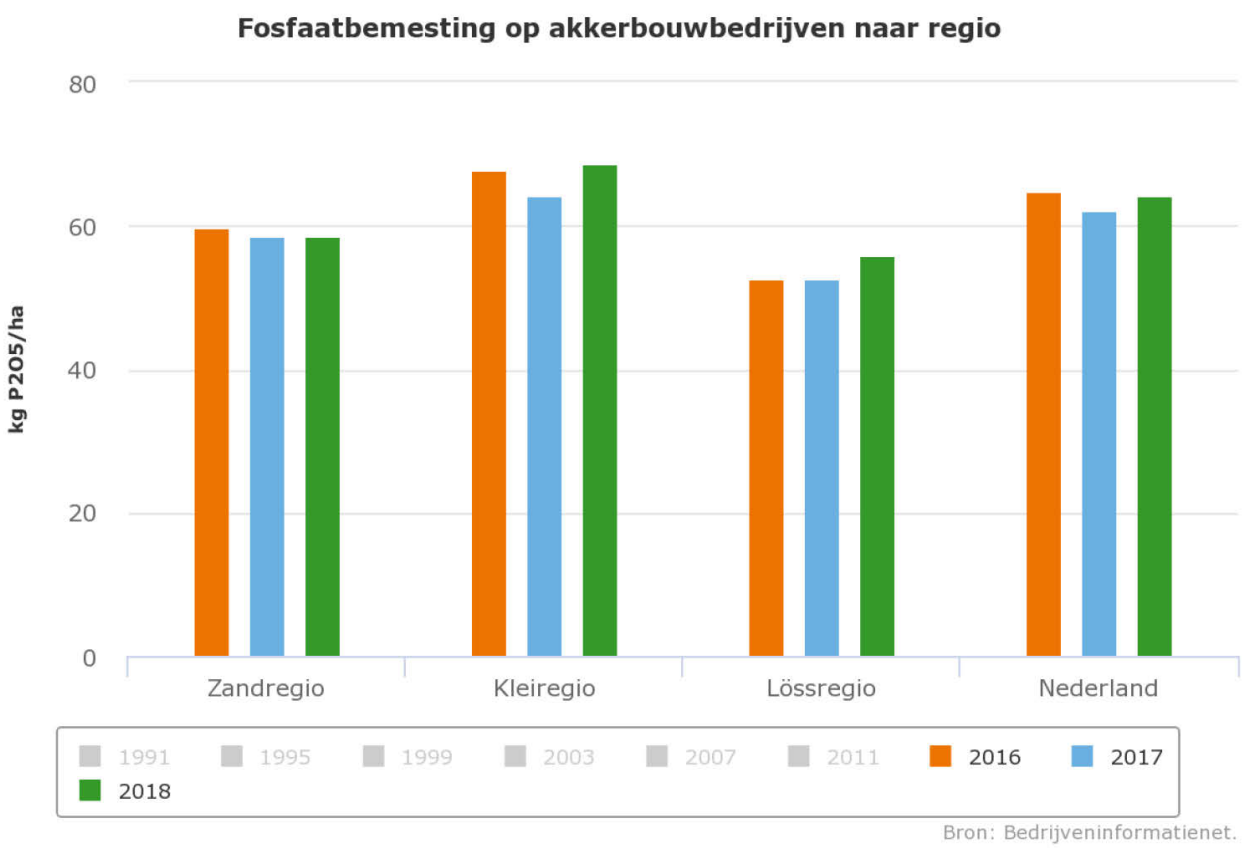

Figuur 24 Fosfaatbemesting op akkerbouwbedrijven in verschillende grondsoortregio's in 2011, 2016, 2017 en 2018 (Bron: WEcR, Agrimatie.nl).

\subsubsection{Overbemesting}

Overbemesting, hier gedefinieerd als bemesting waarbij meer stikstof en/of fosfaat wordt toegediend aan landbouwgronden dan toegestaan volgens de gebruiksnormen, kan leiden tot een verslechtering van de waterkwaliteit. De hoge afzetprijs van mest maakt dat fraude lucratief is (De Koeijer et al., 2018). In de pers verschijnen regelmatig artikelen over mestfraude ${ }^{12}$ die aangeven dat er overbemesting plaatsvindt. Ook zijn er verschillende berekeningen uitgevoerd naar mestplaatsing die erop duiden dat er overbemesting van stikstof en fosfaat plaatsvindt. In het kader van de Evaluatie Meststoffenwet 2016 is een analyse uitgevoerd naar de overbemesting van mest in het zuidelijke veehouderijgebied (Van der Sluis, 2017). Een deel van de berekende overbemesting werd toegeschreven aan onzekerheden

\footnotetext{
${ }^{12}$ Bijvoorbeeld: https://www.nrc.nl/dossier/mestfraude/
} 
in de gebruikte gegevens, maar een deel kan niet verklaard worden en is een mogelijke indicatie van fraude. PBL concludeerde op basis van deze analyse dat een deel van de overschrijding van de waterkwaliteit veroorzaakt wordt door overbemesting. Berekening van de plaatsing met mest en kunstmest met het model INITIATOR voor het jaar 2015 laat zien dat niet alle mest geplaatst kan worden (ca. 25 miljoen kg N en ca. 4 kton $\mathrm{P}_{2} \mathrm{O}_{5}$; Kros et al., 2015). Hierin wordt rekening gehouden met de gebruiksnormen, mestacceptatiegraden in de akkerbouw en mestverwerkings- en export-gegevens van RVO.nl. Het afzetten van deze mest leidt tot overbemesting. Ook CBS berekent een overbemesting van stikstof en fosfaat in verschillende veehouderijgebieden in Nederland (Tabel 11). In 2015 was er een gebrek aan mestafzetmogelijkheden doordat er onvoldoende hygiënisatie en/of andere mestverwerkingscapaciteit beschikbaar was waardoor onvoldoende mest kon worden geëxporteerd. Dit werkte fraude in de hand (De Koeijer et al., 2018).

De onzekerheden in de berekening van mestplaatsing zijn groot. Een van de onzekerheden is de grootte van de gasvormige stikstofverliezen uit stallen. Onderzoek van CBS (Van Bruggen \& Geertjes, 2019) geeft aan dat de stikstofverliezen uit stallen mogelijk veel groter zijn dan nu wordt berekend. Waarschijnlijk wordt dit veroorzaakt door een lagere effectiviteit van ammoniakemissiearme stallen in de praktijk en onzekerheden in emissies van stikstofgas, lachgas en stikstofoxide uit stallen en mestopslagen.

Indicatieve berekeningen van CBS becijferen de onzekerheid op 40 miljoen kg N (CDM, 2020e); als hier rekening mee wordt gehouden in de berekening van mestplaatsing, zal er waarschijnlijk geen of een lage overbemesting zijn. In de handhaving van gebruiksnormen wordt overigens rekening gehouden met de onzekerheden in stikstof- en fosfaatstromen op een bedrijf. ${ }^{13}$ De overbemesting is een berekende waarde, op basis van kengetallen en analysegegevens van mest met onzekerheden. Overbemesting ten opzichte van gebruiksnormen betekent niet dat er ook daadwerkelijk wordt gefraudeerd.

Vanaf 2018 is door het Ministerie van Landbouw, Natuur en Voedselkwaliteit (LNV), in samenwerking met de Rijksdienst voor Ondernemend Nederland (RVO.nl) en de Nederlandse Voedsel- en Warenautoriteit (NVWA), ingezet op een meer op risico's gerichte aanpak van het toezicht en de handhaving van de mestregelgeving. ${ }^{14}$ Deze nieuwe aanpak is vastgelegd in de versterkte handhavingsstrategie mest (VHS). Ook wordt het boetesysteem en hoogte van boetes aangepast om mestfraude tegen te gaan en naleving van de regels van de Meststoffenwet in de praktijk af te dwingen (CDM, 2019a).

Het is niet duidelijk op welke schaal en waar overbemesting plaatsvindt. Wel is duidelijk dat overbemesting het bodemoverschot vergroot en daarmee mogelijk mede een oorzaak kan zijn van een verslechtering van de waterkwaliteit. De mate waarin vergt nader onderzoek.

Tabel 11 Benuttingsgraad dierlijke mest in stikstof en fosfaat (in \% van gebruiksnorm) in verschillende landbouwgebieden en heel Nederland in 2018 (Bron: CBS).

\begin{tabular}{lrr} 
& Benuttingsgraad stikstof, $\%$ & Benuttingsgraad fosfaat, $\%$ \\
Bouwhoek en Hogeland (LG) & 81 & 76 \\
\hline Veenkoloniën en Oldambt (LG) & 78 & 77 \\
\hline Noordelijk Weidegebied (LG) & 101 & 89 \\
\hline Oostelijk Veehouderijgebied (LG) & 102 & 94 \\
\hline Centraal Veehouderijgebied (LG) & 120 & 119 \\
\hline IJsselmeerpolders (LG) & 78 & 72 \\
Westelijk Holland (LG) & 76 & 71 \\
\hline Waterland en Droogmakerijen (LG) & 85 & 80 \\
\hline Hollands/Utrechts Weidegebied (LG) & 104 & 92 \\
\hline Rivierengebied (LG) & 96 & 87 \\
\hline Zuidwestelijk Akkerbouwgebied (LG) & 66 & 65 \\
\hline Zuidwest-Brabant (LG) & 88 & 84 \\
\hline Zuidelijk Veehouderijgebied (LG) & 125 & 126 \\
\hline Zuid-Limburg (LG) & 85 & 74 \\
\hline Nederland & & 88
\end{tabular}

\footnotetext{
${ }^{13}$ https://www.rvo.nl/onderwerpen/agrarisch-ondernemen/mest/controle-en-handhaving/controle-opgebruiksnormen/marges-bij-handhaving

${ }^{14}$ https://www.rijksoverheid.nl/documenten/kamerstukken/2019/11/15/kamerbrief-over-voortgangsrapportage-versterktehandhavingsstrategie-mest-en-update-waterkwaliteit-derogatiebedrijven
} 


\subsection{Samenvatting}

De totale mestproductie in Nederland uitgedrukt in stikstof is toegenomen in de periode 2012-2017 door de toename van het aantal koeien en een toename van de stikstofexcretie per koe. In 2018 en 2019 is de totale stikstofproductie iets gedaald door een daling van het aantal koeien. De totale stikstofproductie in mest is in 2019 gelijk aan die van 2010. De fosfaatproductie is ook gestegen in de periode 2012-2015, maar is daarna afgenomen door een daling van het aantal koeien en daling/ stabilisatie van de fosfaatexcretie per koe. De fosfaatproductie in 2019 is $13 \%$ lager dan in 2010. In 2017 is het stikstofplafond overschreden en in 2016 en 2018 lag de stikstofproductie net onder het plafond. Het fosfaatplafond is in 2010, 2015 en 2016 overschreden, maar na 2016 lag de fosfaatproductie onder het plafond.

De plaatsingsruimte voor dierlijke mest is in de periode 2010-2019 afgenomen, zowel uitgedrukt in stikstof als fosfaat. De toename van de mestproductie door melkvee is een belangrijke oorzaak voor de sterke toename van mestafzet buiten de Nederlandse landbouw in de periode 2015-2017.

De bij RVO geregistreerde mestverwerkingsovereenkomsten laten zien dat in 2018 voor in totaal 40,6 miljoen $\mathrm{kg}$ fosfaat geregistreerd is als verwerking en export in het kader van de verplichte mestverwerking. De meeste mest wordt geëxporteerd naar Duitsland, België en Frankrijk. In 2017 en 2018 is de mestexport naar Duitsland gedaald, terwijl de export naar België en Frankrijk iets toenam. De gerealiseerde verwerking/export van mest vanaf de inwerkingtreding van de verplichte mestverwerking in 2014 is steeds voldoende geweest om het totale fosfaatoverschot te verwerken of te exporteren.

De totale stikstofbemesting als kunstmest en werkzame $\mathrm{N}$ in dierlijke mest op grasland schommelt tussen de jaren, maar er is geen duidelijke trend zichtbaar in de periode 2010-2018. Op melkveebedrijven met een derogatie wordt de gebruiksnorm werkzame stikstof de laatste jaren bijna volledig opgevuld; alleen in het droge jaar 2018 is er duidelijk minder stikstof gebruikt dan de gebruiksnorm. De fosfaatbemesting op melkveebedrijven neemt sterk af, voornamelijk doordat er amper nog fosfaat-kunstmest wordt gebruikt op melkveebedrijven. De stikstofbemesting op akkerbouwbedrijven op zand- en lössgrond is de laatste jaren gedaald, terwijl die van kleigrond is gestegen. De stikstofgebruiksnorm voor dierlijke mest wordt niet opgevuld op akkerbouwbedrijven. De fosfaatbemesting op akkerbouwbedrijven is in de laatste jaren weinig veranderd. Wel neemt het gebruik van kunstmest af en het gebruik van overige organische meststoffen toe.

Modelberekeningen geven aan dat er in de praktijk meer bemest wordt dan volgens de gebruiksnormen is toegestaan. Echter de modelberekeningen kennen grote onzekerheden. Het is niet duidelijk op welke schaal en waar overbemesting plaatsvindt. Wel is duidelijk dat overbemesting het bodemoverschot sterk vergroot en daarmee mogelijk mede een belangrijke oorzaak kan zijn van een verslechtering van de waterkwaliteit. De mate waarin vergt nader onderzoek. 


\section{Stikstof- en fosfaatbalansen van de Nederlandse landbouw}

\subsection{Stikstof- en fosfaatbalansen van cultuurgrond}

Het overschot op de stikstof- en fosfaatbalans is een indicator voor verlies van stikstof en fosfaat naar het milieu. In Tabel 12 worden de stikstof- en fosfaatbalansen van cultuurgrond van Nederland weergegeven in de periode 2010-2018. In deze balansen is de aanvoer van stikstof en fosfaat via dierlijke mest, kunstmest, andere bronnen (bijvoorbeeld compost) en (voor stikstof) atmosferische depositie en de afvoer via geoogste gewassen en (voor stikstof) de ammoniakemissie berekend. Het verschil is het verlies naar de bodem. Dit verlies bestaat uit uitspoeling naar grond- en oppervlaktewater, ophoping in de bodem en (voor stikstof) gasvormig stikstofverlies via denitrificatie. Uit de balansberekening volgt dat het stikstofverlies naar de bodem is toegenomen in de periode vanaf 2015; dit wordt verklaard door de grote mestproductie in deze periode (paragraaf 5.1). De fosfaatbalans is laag en fluctueert tussen de jaren. De fluctuaties worden met name veroorzaakt door fluctuaties in de fosfaat-afvoer via geoogst gras en maïs.

Tabel 12 Stikstof- en fosfaatbalansen van cultuurgrond in Nederland (Bron: CBS).

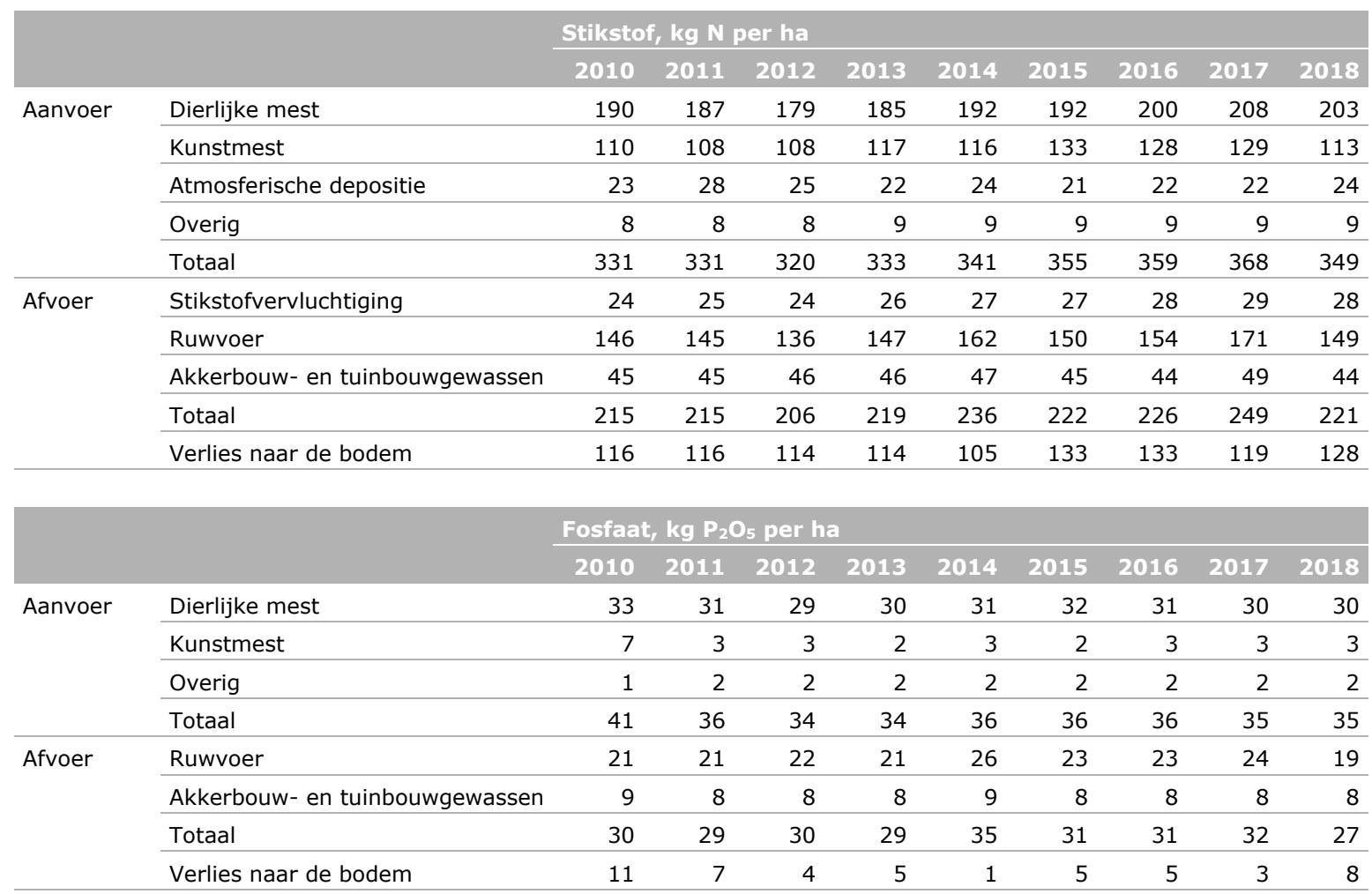

\subsection{Stikstof- en fosfaatbalansen van de melkveehouderij en de akkerbouw}

De stikstofoverschotten op de bodembalans van bedrijven uit het Landelijk Meetnet Effecten Mestbeleid (LMM) zijn sinds 2010 niet sterk meer veranderd (Figuur 25; Figuur 26). De laatste jaren is er sprake van enige fluctuatie door effecten van het weer op opbrengsten. In 2018 gaat het stikstofoverschot in de meeste grondsoortregio's omhoog, doordat de opbrengst na de droge zomer lager was. In 2018 was het stikstofbodemoverschot van melkveebedrijven in de zandregio $153 \mathrm{~kg} \mathrm{~N}$ 
per ha, in de kleiregio $188 \mathrm{~kg}$ per ha, in de lössregio $151 \mathrm{~kg} \mathrm{~N}$ per ha en in de veenregio $219 \mathrm{~kg} \mathrm{~N}$ per ha. Het hogere stikstofoverschot in de veenregio wordt veroorzaakt doordat de stikstofmineralisatie van veen (90 tot $100 \mathrm{~kg} \mathrm{~N}$ per ha) wordt meegenomen in de berekening. De stikstofoverschotten zijn duidelijk lager op akkerbouw- dan op melkveebedrijven. In 2018 was het stikstofbodemoverschot van akkerbouwbedrijven in de zandregio $100 \mathrm{~kg} \mathrm{~N}$ per ha, in de kleiregio $128 \mathrm{~kg}$ per ha en in de lössregio $90 \mathrm{~kg} \mathrm{~N}$ per ha.

De fosfaatoverschotten op de bodembalans van LMM-bedrijven zijn de laatste tien jaar afgenomen (Figuur 27; Figuur 28). Op melkveebedrijven is in alle grondsoortregio's het niveau van evenwichtsbemesting (aanvoer = afvoer) bereikt. De fosfaatoverschotten op akkerbouwbedrijven zijn in de löss-regio lager dan in de zand- en kleiregio's; in de lössregio is het niveau van evenwichtsbemesting bereikt en ook in de zand- en kleiregio's is het fosfaatoverschot laag. In 2018 is het fosfaatoverschot weer gestegen op zowel melkvee- als akkerbouwbedrijven en in alle grondsoortregio's door de lagere opbrengsten door droogte.
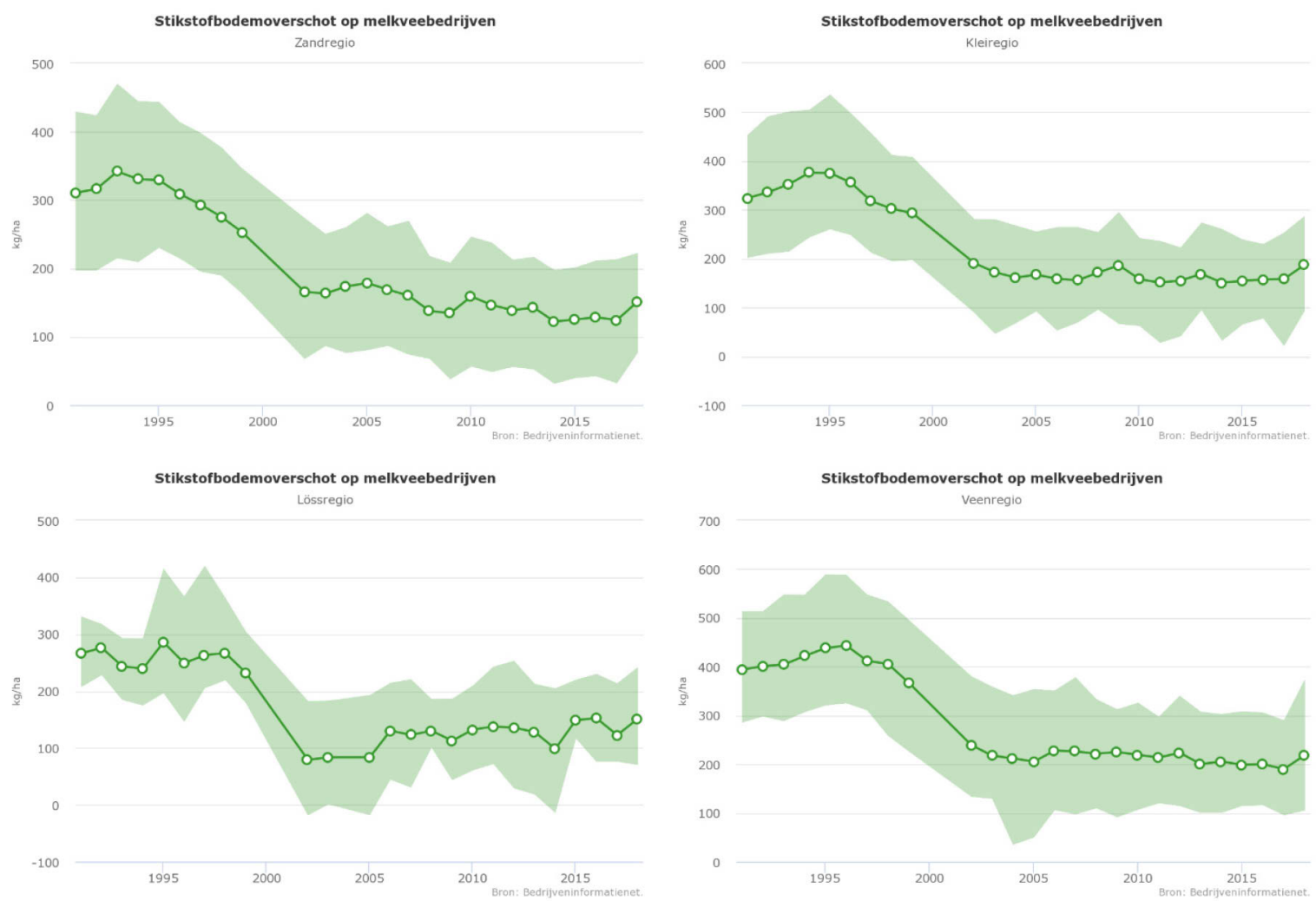

Figuur 25 Ontwikkeling in het stikstofoverschot op melkveebedrijven in de zand-, klei- löss- en veenregio's van het Landelijk Meetnet Effecten Mestbeleid (LMM); gemiddelde en 10- en 90-percentiel per jaar (Bron: agrimatie.nl). 


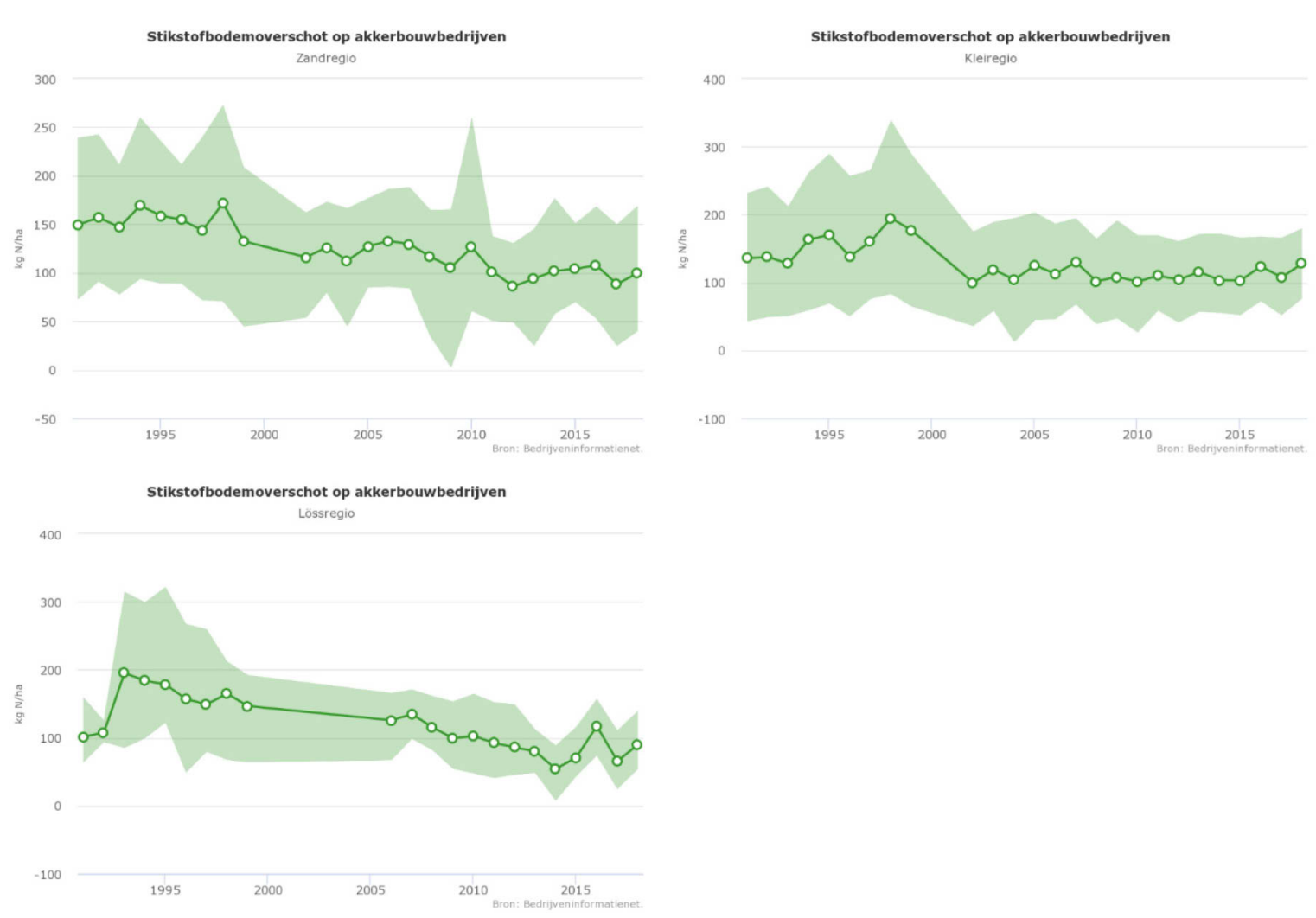

Figuur 26 Ontwikkeling in het stikstofoverschot op akkerbouwbedrijven in de zand-, klei- en lössregio's van het Landelijk Meetnet Effecten Mestbeleid (LMM); gemiddelde en 10- en 90-percentiel per jaar (Bron: agrimatie.nI).
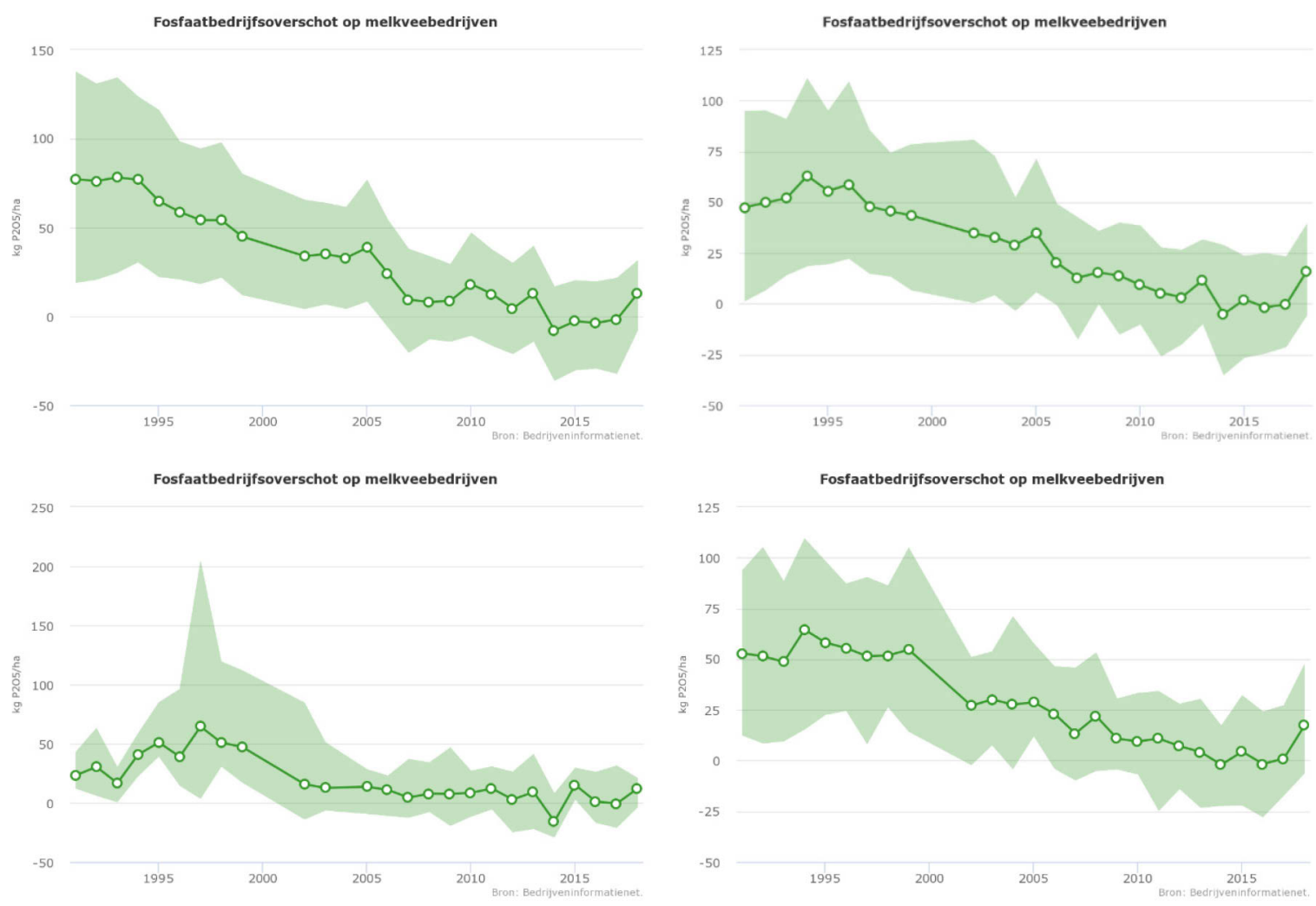

Figuur 27 Ontwikkeling in het fosfaatoverschot op melkveebouwbedrijven in de zand-, klei-, lössen veenregio's van het Landelijk Meetnet Effecten Mestbeleid (LMM); gemiddelde en 10- en 90percentiel per jaar (Bron: agrimatie.nl). 


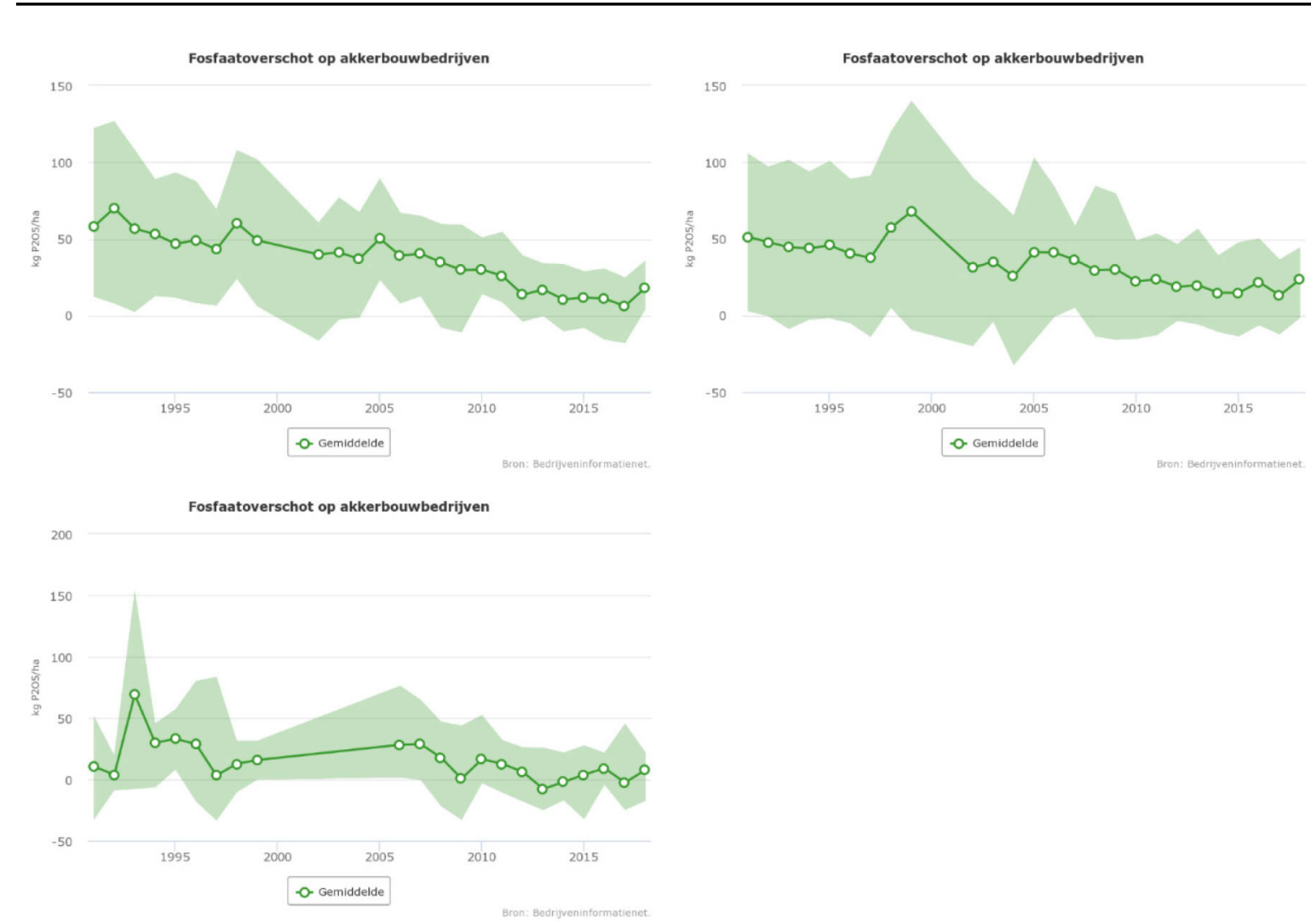

Figuur 28 Ontwikkeling in het fosfaatoverschot op akkerbouwbedrijven in de zand-, klei- en lössregio's van het Landelijk Meetnet Effecten Mestbeleid (LMM); gemiddelde en 10- en 90-percentiel per jaar (Bron: agrimatie.nI).

\subsection{Samenvatting}

De stikstofoverschotten op de bodembalans van bedrijven uit het Landelijk Meetnet Effecten Mestbeleid (LMM) zijn sinds 2010 niet sterk meer veranderd. De laatste jaren is er sprake van enige fluctuatie door effecten van het weer op opbrengsten. In 2018 zijn de stikstof- en fosfaatoverschotten in de meeste grondsoortregio's omhooggegaan vanwege lagere opbrengsten door droogte. 


\section{$7 \quad$ Bodemkwaliteit}

\subsection{Inleiding}

Er zijn zorgen over de kwaliteit van landbouwgronden (Raad voor de Leefomgeving en infrastructuur (RLi), 2020). Een slechte bodemkwaliteit kan leiden tot lagere opbrengsten, waardoor de opname van stikstof en fosfaat lager wordt en risico op uitspoeling groter wordt. Een slechte bodemstructuur kan mogelijk leiden tot een hoger risico op afspoeling van stikstof en fosfaat naar het oppervlaktewater. In dit hoofdstuk wordt ingegaan op ontwikkelingen in de kwaliteit van landbouwbodems en mogelijke effecten op waterkwaliteit.

\subsection{Gehalte aan organische stof}

Organische stof bevindt zich in de bodem en is een verzamelnaam voor verschillende soorten materiaal van organische afkomst, dat voor 40-65\% uit koolstof bestaat (Koopmans \& Van Opheusden, 2019). Het kan bestaan uit dood organisch materiaal, zoals onverteerde plantenresten, of levend organisch materiaal, zoals wortels, bacteriën en ander bodemleven (Koopmans \& Van Opheusden, 2019). Organische stof speelt een belangrijke rol in de voedselvoorziening voor organismen in de bodem, in het vasthouden en loslaten van water en nutriënten en bij het opslaan van koolstof. Het gehalte aan organische stof in de bodem heeft een positieve relatie met de (bodem)biodiversiteit, de bodemstructuur, de waterhuishouding, de nutriëntenbalans, de bodemzuurgraad en de plaag- en ziektebestrijding en heeft daardoor effect op de stikstofbenutting door het gewas en op stikstofverliezen door nitraatuitspoeling.

Het gehalte aan organische stof in bodemmonsters uit de toplaag van de bodem (gegevens van Eurofins) laat voor de periode 1985 tot 2018 een stabiele tot licht stijgende trend zien voor grasland, bouwland (akkerbouw) en maïsland (Figuur 29). Dit zijn trends gemiddeld over alle grondsoorten. Een nadere analyse van trends in de periode 2005-2015 voor combinaties gewasgroep (grasland, bouwland, akkerbouw) en grondsoort (dekzand, rivierklei, zeeklei, dalgrond, löss en veen en kleiig veen) laat ook geen daling zien en een daling is ook niet zichtbaar indien de trends op het niveau van landbouwgebieden worden geanalyseerd (Velthof et al., 2017).

In 2008 zijn 1392 punten door heel Nederland gestructureerd bemonsterd en gekarakteriseerd om de nauwkeurigheid van de bodemkaart van Nederland te bepalen. Hierbij werd ook het organischestofgehalte bepaald. In 2018 zijn deze metingen herhaald in het kader van het programma Slim landgebruik (Tol-Leenders et al., 2019). 85\% van de oorspronkelijk punten kon opnieuw gevonden en gemeten worden. Uit de resultaten bleek dat het gehalte aan organische stof in de laag 0-30 cm van minerale landbouwgronden in de periode 2008 (gemiddeld gehalte aan organische stof: $4,01 \%$ ) tot 2018 (gemiddeld gehalte aan organische stof: 4,11\%) niet is gedaald. In veengronden en moerige grond was wel sprake van een daling van het gehalte aan organische stof in de laag 0-30 cm.

In een studie van Groenendijk et al. (2019) werd geconcludeerd dat het effect van organische stof op het voorkomen en verminderen van droogteschade bij gewassen voornamelijk een rol speelt in gronden met een laag percentage ( $<2$ à $3 \%$ organische stof). Het areaal van dergelijke gronden is klein in Nederland. De CDM (2017c) concludeert dat uit de literatuur geen eenduidig beeld naar voren komt over het effect van organische stof in de bodem van minerale gronden op de grootte van de nitraatuitspoeling. Een toename van de nitraatuitspoeling door veeljarig gebruik van organische meststoffen kan worden verklaard door een toename van de mineralisatie van organische stikstof binnen en buiten het groeiseizoen. Een vermindering van de nitraatuitspoeling door veeljarig gebruik van organische meststoffen kan worden verklaard door een toename van de denitrificatiecapaciteit en/of door een verbetering van de bodemkwaliteit en daardoor een hogere stikstofopname door het 
gewas. De effecten van het organischestofgehalte van de bodem en van de toediening van organische meststoffen op nitraatuitspoeling kunnen niet goed worden aangegeven zonder de wisselwerkingen tussen type meststof, hoogte van de stikstofgift, stikstofmineralisatie, stikstofopname door het hoofden vanggewas, denitrificatie, grondsoort en weersomstandigheden erbij te betrekken CDM (2017c).

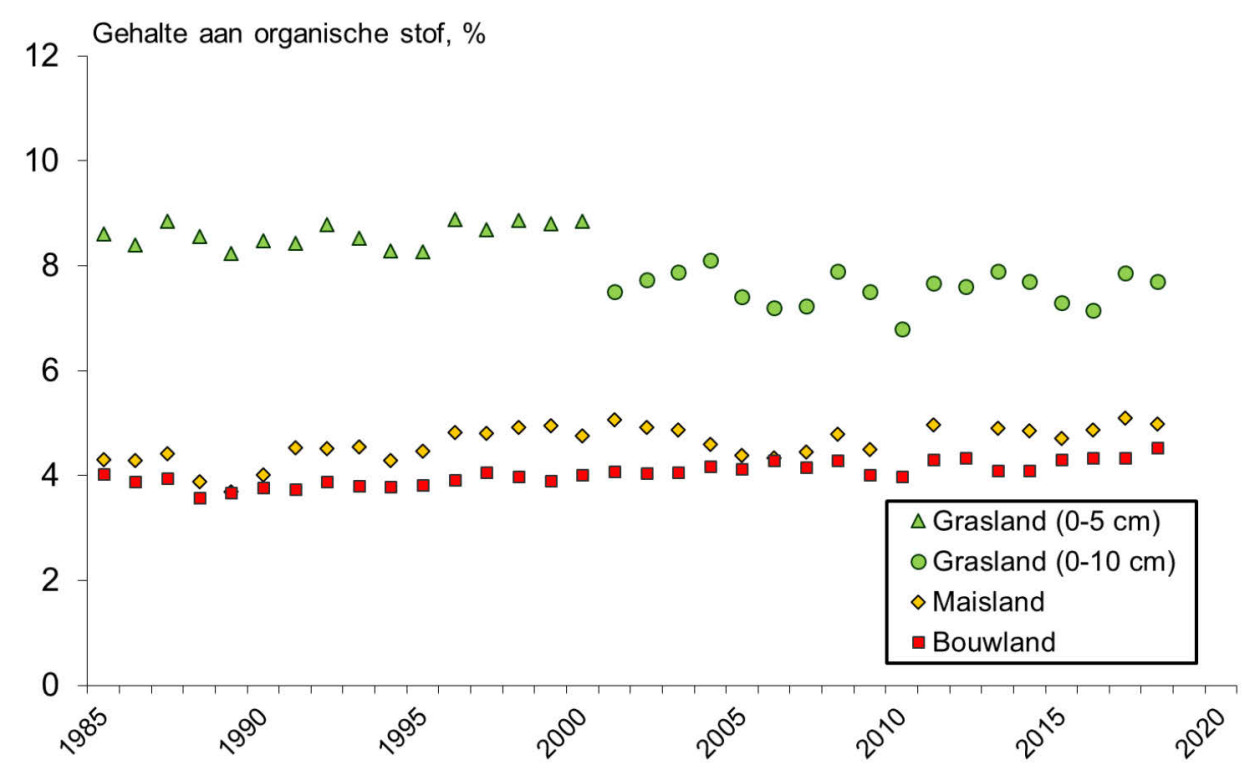

Figuur 29 Gemiddelde trends van het gehalte aan organische stof in bodemmonsters van grasland (0-5 cm in periode $1995-2001$ en 0-10 cm vanaf 2002), maïsland $(0-25 \mathrm{~cm})$ en akkerbouw $(0-20 \mathrm{~cm})$ in de periode 1985-2018 (Bron: Eurofins Agro).

\subsection{Beschikbaarheid van nutriënten}

Wageningen Environmental Research heeft samen met Eurofins een analyse gemaakt van de chemische bodemkwaliteit, als achtergronddocument voor de studie van de Raad voor de leefomgeving en infrastructuur ${ }^{15}$ (Beltman et al., 2019). Onderstaande teksten en resultaten zijn afkomstig van de studie van Beltman et al. (2019) en gaan in op de chemische bodemvruchtbaarheid.

Voor een optimale gewasgroei zijn nutriënten nodig. Het gaat hierbij om de hoofdelementen stikstof $(\mathrm{N})$, fosfor $(\mathrm{P})$, kalium $(\mathrm{K})$, magnesium $(\mathrm{Mg})$, calcium $(\mathrm{Ca})$ en zwavel $(\mathrm{S})$ en de sporenelementen borium (B), molybdeen (Mo), mangaan (Mn), koper (Cu), kobalt (Co), seleen (Se), zink (Zn) en ijzer $(F e)$. De bodem levert een deel van deze nutriënten, de rest van de gewasbehoefte moet worden aangevuld met kunstmest en dierlijke mest. Bij de bemestingsadviezen van gewassen wordt rekening gehouden met de levering van de nutriënten door de bodem (CBGV, 2019 en CBAV, 2019). Bij een tekort aan een van deze nutriënten kan opbrengstderving optreden en kan de opname van andere nutriënten worden geremd. De niet-opgenomen nutriënten kunnen verloren gaan in het milieu. Een slechte chemische bodemvruchtbaarheid kan dus leiden tot meer nitraat- en fosfaatuitspoeling.

\subsubsection{Stikstof}

Het grootste deel van de stikstof in de bodem is aanwezig als organische stikstof. Deze komt vrij na mineralisatie door bodemorganismen. Daarnaast is stikstof aanwezig in minerale (anorganische) vorm: nitraat $\left(\mathrm{NO}_{3}{ }^{-}\right)$en ammonium $\left(\mathrm{NH}_{4}{ }^{+}\right)$. De hoeveelheid minerale $\mathrm{N}$ in de bodem fluctueert sterk in de tijd door management (bemesting) en allerlei biologische processen, zoals mineralisatie, immobilisatie en denitrificatie. Stikstof kan gemakkelijk verloren gaan uit de bodem door uitspoeling, ammoniakemissie en denitrificatie. Door deze fluctuaties in het gehalte aan minerale stikstof in de

\footnotetext{
${ }^{15}$ https://www.rli.nl/sites/default/files/advies_de_bodem_bereikt_-_def.pdf
} 
bodem is het niet mogelijk om een algemene karakterisering te geven van de chemische bodemvruchtbaarheid met betrekking tot minerale stikstof van Nederlandse landbouwgronden. De beschikbare metingen reflecteren daarvoor te veel een momentopname.

\subsubsection{Fosfor}

Fosfor speelt een belangrijke rol in de ontwikkeling van gewassen (vorming van eiwitten, ademhaling, fotosynthese, wortelontwikkeling). Een fosfortekort kan leiden tot opbrengstderving en/of vermindering van de productkwaliteit. Fosfor (vaak uitgedrukt als fosfaat) is weinig mobiel in landbouwgronden. Uit- en afspoeling van fosfor leidt tot eutrofiëring van het oppervlaktewater. De hoeveelheid fosfor die aan landbouwgronden is toegediend met kunstmest en dierlijke mest is sinds de jaren tachtig van de vorige eeuw veel hoger geweest dan de fosforafvoer met geoogste gewassen. Hierdoor is de fosfor in de bodem opgehoopt en is de fosfaattoestand van veel landbouwgronden hoog. Uit bodems die verzadigd zijn, kan fosfaat uitspoelen (Schoumans, 2015). Ook de grondwatertrap heeft effect op het risico op uit- en afspoeling naar het oppervlaktewater: hoe natter de bodem, hoe groter risico op uit- en afspoeling van fosfaat.

De fosfaattoestand van de bodem als bodemvruchtbaarheidsparameter wordt op basis van chemische extracties bepaald. ${ }^{16}$ De ophoping van fosfor in landbouwgronden is vooral goed zichtbaar in het P-Algetal van de bodem (zie Figuur 30 voor grasland). Bij een P-Al-getal hoger dan 50 hoeft er amper meer fosfor te worden toegediend om de optimale opbrengst te realiseren. P-Al-getallen groter dan 50 komen vooral voor in de zandgebieden waar veel dierlijke mest is gebruikt, zoals de Gelderse Vallei, grote delen van Noord-Brabant en de Achterhoek. In deze regio's is het gehalte van $\mathrm{P}-\mathrm{CaCl}_{2}$, een indicator voor het direct beschikbare fosfaat, ook hoog (Figuur 30). Het gehalte van $\mathrm{P}-\mathrm{CaCl}_{2}$ wordt ook beïnvloed door bodemeigenschappen, zoals het gehalte aan Fe- en Al-(hydr)oxiden en klei, waardoor er duidelijk verschillen zijn in de beschikbaarheid van P tussen grondsoorten (Figuur 30).

In het kader van de Evaluatie Meststoffenwet 2016 is op basis van cijfers van Eurofins Agro een nadere analyse uitgevoerd van de trends van de fosfaattoestand in landbouwgronden (Velthof et al., 2017). Hieruit blijkt dat het P-Al-getal in landbouwgronden gemiddeld in Nederland stabiel is gebleven in de periode 2005-2015. Dit correspondeert met het feit dat er tot 2014 gemiddeld nog steeds sprake was van een fosfaatoverschot (Tabel 12; Figuur 27; Figuur 28). De indicator van het direct beschikbare fosfaat $\left(\mathrm{P}-\mathrm{CaCl}_{2}\right)$ laat voor verschillende combinaties van gewas-grondsoort een daling zien in deze periode, met name voor grasland op dekzand en rivierklei, maïsland op rivierklei en akkerbouw op rivier- en zeeklei (Velthof et al., 2017). De lagere fosfaatbemesting door de aangescherpte gebruiksnormen heeft waarschijnlijk geleid tot deze daling in het direct beschikbare fosfaat. Vanwege de veelal grote P-voorraad in landbouwgronden leidt een daling van het beschikbare $\mathrm{P}\left(\mathrm{P}-\mathrm{CaCl}_{2}\right)$ landbouwkundig gezien echter niet tot effecten op gewasopbrengst dan wel kwaliteit; de zogenoemde P-toestand van deze bodems is vaak nog steeds 'voldoende' tot 'hoog'.

\subsubsection{Kalium en magnesium}

De kaliumtoestand (extractie met 0,01 $\mathrm{M} \mathrm{CaCl}_{2}$-oplossing) van landbouwgronden op klei- en veengrond wordt landbouwkundig als goed tot hoog gewaardeerd. Kalium is belangrijk voor de opbrengst en kwaliteit van gewassen. Te veel kalium kan leiden tot problemen met de gezondheid van koeien (zie hieronder bij magnesium). In een deel van de zandgronden is de K-toestand vrij laag. Kalium kan worden toegediend aan landbouwgronden via kunstmest en dierlijke mest. De Kbeschikbaarheid leek de laatste jaren wat achteruit te gaan (minder dierlijke mest), maar doordat agrariërs meer aandacht aan kalium besteedden door meer kunstmest te geven, blijft de K-toestand ongeveer gelijk. De droge zomers van 2018 en 2019 hebben tot een hoge K-toestand geleid, doordat de uitspoeling en opname van $\mathrm{K}$ lager waren dan normaal.

Een magnesiumtekort bij akkerbouwgewassen kan leiden tot opbrengstderving en verlies van kwaliteit van het geoogste product. Magnesium is daarnaast belangrijk met het oog op diergezondheid. Met name bij een hoge kaliumbeschikbaarheid kan de magnesiumopname worden geremd en dit kan

\footnotetext{
${ }^{16}$ Het P-Al-getal (extractie met ammoniumlactaat) representeert ruwweg 50\% van de totale hoeveelheid fosfaat in de bodem (de rest is te sterk gebonden en niet beschikbaar voor gewasopname), $\mathrm{P}-\mathrm{CaCl}_{2}$ ongeveer $1 \%$.
} 
leiden tot verlaging van melkproductie van koeien en tot kopziekte. De magnesiumtoestand van landbouwgronden is in het algemeen goed tot hoog. Met name de veengronden hebben een hoge magnesiumtoestand. Op lokale schaal, zoals de Noordoostpolder en in een deel van de zandgronden, is de magnesiumtoestand vrij laag. Magnesium kan worden toegediend met magnesiumhoudende meststoffen. Ook dierlijke mest bevat magnesium.
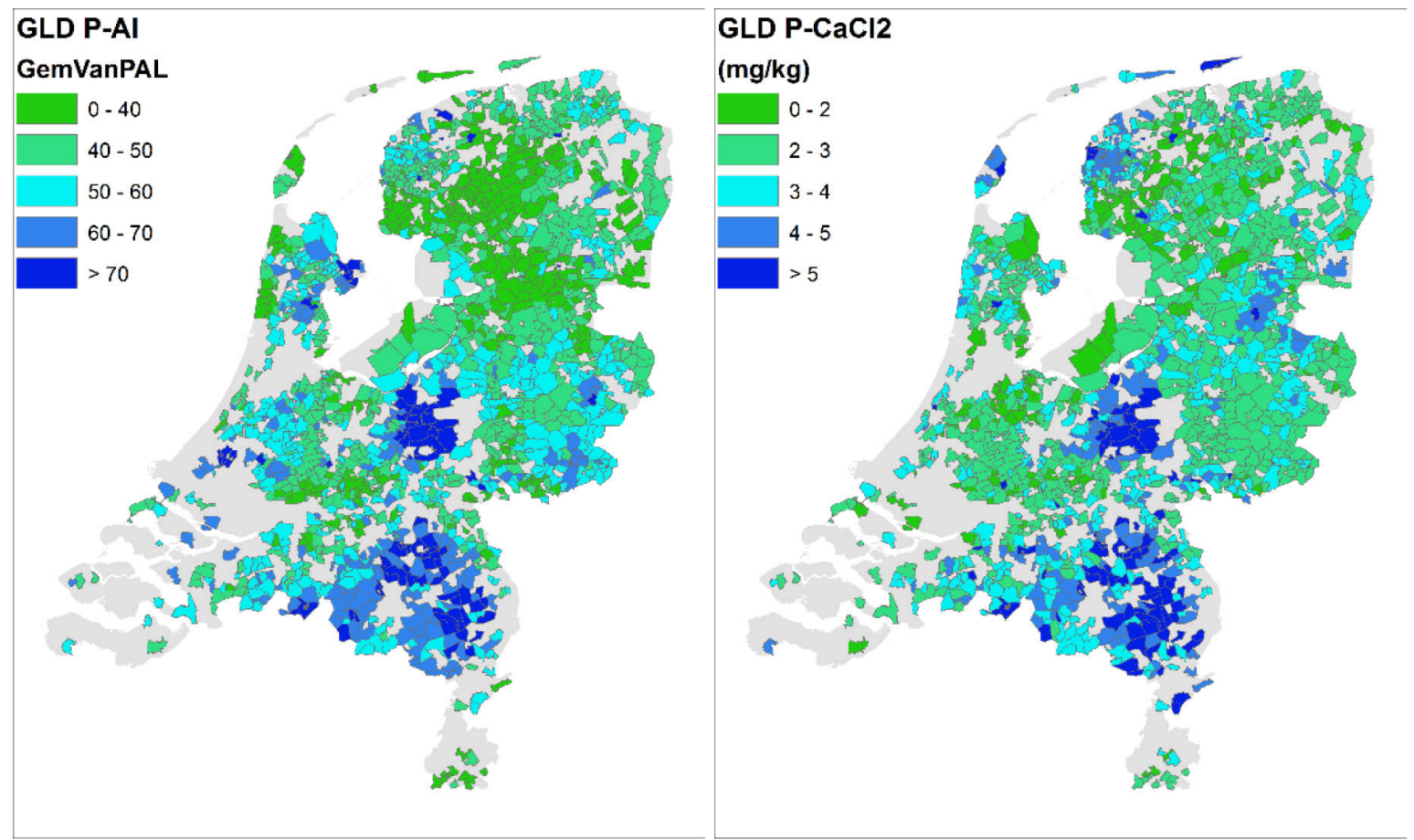

Figuur $30 \quad P$-Al en $\mathrm{P}-\mathrm{CaCl}_{2}$ gemeten in grasland per postcode gebied (Bron: Eurofins Agro). ${ }^{17}$

\subsection{Zuurgraad $(\mathrm{pH})$}

De zuurgraad $(\mathrm{pH})$ van de bodem heeft belangrijke rol bij de gewasgroei. Als de $\mathrm{pH}$ te laag is, kan de gewasgroei worden geremd. Ook biologische processen in de bodem worden geremd bij een lage $\mathrm{pH}$. Verder heeft de $\mathrm{pH}$ een effect op de beschikbaarheid voor planten van sommige nutriënten, zoals fosfaat (lagere beschikbaarheid bij zowel lage als hoge $\mathrm{pH}$ ) en sommige spoorelementen. De $\mathrm{pH}$ in de meeste landbouwgronden wordt in het algemeen landbouwkundig als goed gewaardeerd (de waardering is afhankelijk van grondsoort en gewas). De hoogste $\mathrm{pH}$-waarden worden gevonden in de klei- en zavelgronden en de lössgronden (Figuur 31). De pH in de klasse lager dan 5 is landbouwkundig gezien laag voor akkerbouw op zandgrond. $\mathrm{De} \mathrm{pH}$ in de klasse lager dan respectievelijk 4,8 en 4.6 is landbouwkundig gezien laag voor niet-veengraslanden. Met name in Drenthe en in de kop van Overijssel zijn er gebieden met een lage $\mathrm{pH}$. Door middel van bekalking volgens het bemestingsadvies kan de $\mathrm{pH}$ worden verhoogd.

\footnotetext{
${ }^{17}$ In de figuren zijn gegevens gebruikt van Eurofins Agro voor grasland $(0-10 \mathrm{~cm})$ en bouwland $(0-25 \mathrm{~cm})$ op postcodeniveau (> 20 monsters per postcodegebied) in de periode 2015-2018. De gepresenteerde waarden zijn de gemiddelden per postcodegebied. Het totaalaantal monsters bedraagt per nutriënt meer dan 70.000.
} 


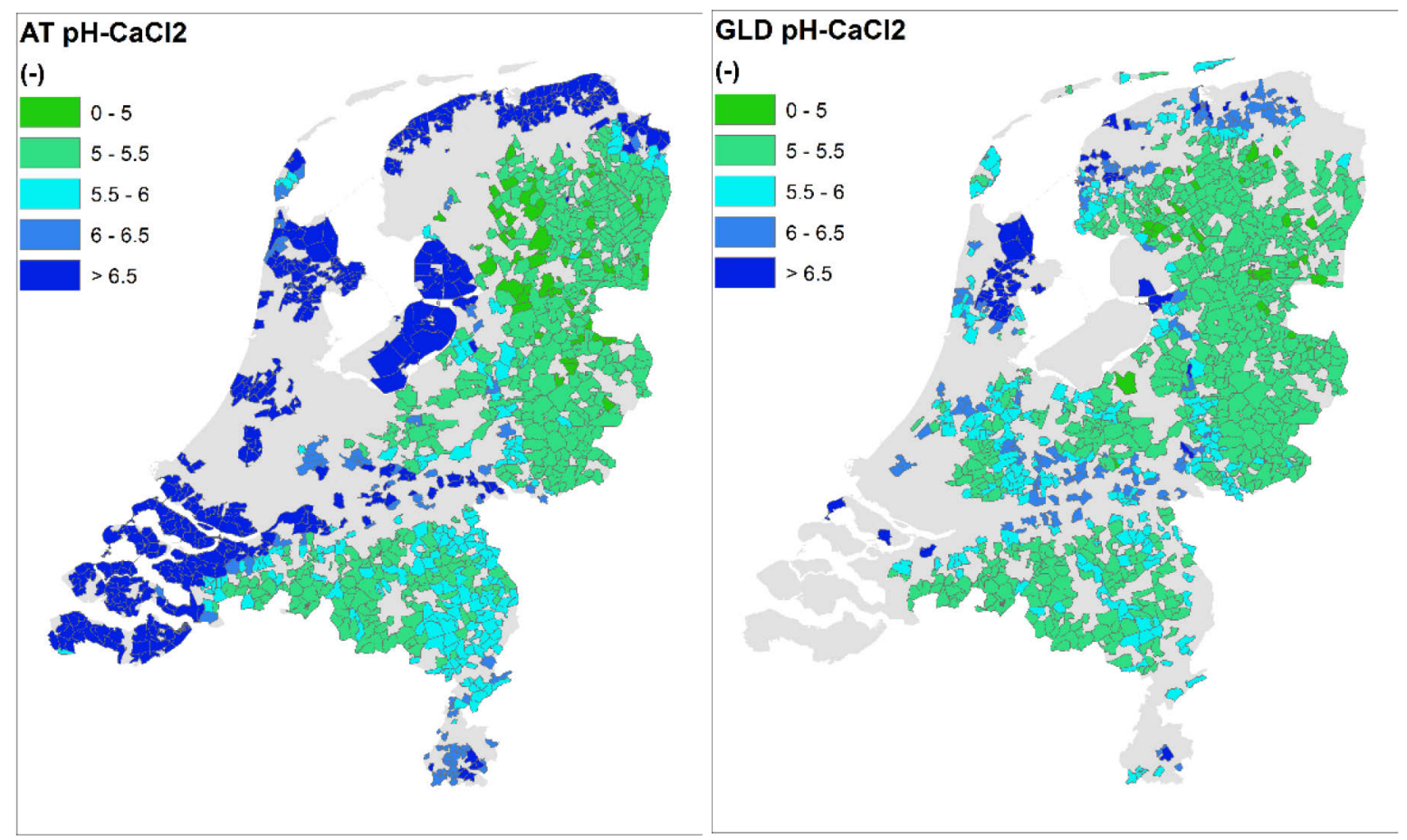

Figuur $31 \mathrm{PH}$ ( $\mathrm{CaCl}_{2}$-extractie) in de bodem voor akkerbouw (links) en grasland (rechts) per postcode gebied (Bron: Eurofins Agro).

\subsection{Bodemverdichting}

Bodemverdichting wordt meestal veroorzaakt door verdichting en vervorming van de bodemstructuur door landbouwvoertuigen. Dit geldt vooral bij bewerkingsactiviteiten op het verkeerde moment en/of door apparatuur met een te hoge bandendruk. Door verdichting daalt het poriënvolume van de bodem en dit beïnvloedt de doorlatendheid van de bodem voor water en lucht, de bewortelbaarheid en de zuurstofvoorziening. Er kan onderscheid worden gemaakt tussen verdichting van de bovengrond en ondergrond. De bovengrond kan worden geploegd, waardoor de verdichting in de bovenste ca. $30 \mathrm{~cm}$ wordt opgeheven. Verdichting van de ondergrond onder de ploegzool is een doorlopend cumulatief proces, dat op de lange duur resulteert in een blijvend homogeen verdichte ondergrond (Van den Akker, 2019). Een goed opgezette, systematische inventarisatie naar ondergrondverdichting en maatregelen om ondergrondverdichting op te heffen, heeft in Nederland nooit plaatsgevonden. Uit een beperkte inventarisatie (128 locaties) blijkt dat 45\% van het oppervlakte van Nederlandse ondergronden oververdicht is (Van den Akker, 2019). Voor de provincies Gelderland, Brabant en Zeeland zijn deze percentages respectievelijk 62, 67 en 43 . Verslemping is het proces waarin het bodemoppervlak is verdicht. Problemen met verslemping treden op in lössgronden, zavelgrond en lichte kleigronden.

Verdichting en/of verslemping van de bovengrond en ondergrondverdichting kunnen via verschillende mechanismen de uit- en afspoeling van stikstof en fosfaat beïnvloeden:

- De gewasopbrengst is vaak lager bij een verdichte grond, omdat de beworteling wordt geremd en er zuurstofloze omstandigheden in de bouwvoor optreden. De reductie van de gewasopbrengst is sterk afhankelijk van het weer en bedraagt bij ondergrondverdichting ongeveer 10 tot $35 \%$ (Van den Akker en Hendriks, 2015).

- Vooral in droge jaren kan ondergrondverdichting leiden tot opbrengstdervingen. Door opbrengstderving zal een gewas minder stikstof en fosfaat opnemen, waardoor het risico op uitspoeling toeneemt.

- Ondergrondverdichting kan tot een sterke afname van de infiltratiecapaciteit van de bodem leiden, waardoor bij veel neerslag de bouwvoor verzadigd raakt en het overtollige water over het bodemoppervlak naar het oppervlaktewater stroomt. Via oppervlakkige afspoeling van water worden ook stikstof en fosfaat naar het oppervlaktewater getransporteerd. Ook bij verslempte bodems of bodems met een verdichte bovengrond bestaat er risico op oppervlakkige afspoeling. 
- Onder natte omstandigheden kan bij verslemping en verdichting (boven- en ondergrond) het zuurstofgehalte dalen in de bouwvoor, waardoor het aanwezige nitraat afgebroken wordt door denitrificerende bacteriën. Als dit tijdens de groeiperiode optreedt, kan er een stikstoftekort bij het gewas optreden. Treedt dit na de groeiperiode op, dan kan denitrificatie leiden tot minder nitraatuitspoeling.

Het is niet bekend welke rol bodemverdichting speelt bij de belasting van grond- en oppervlaktewater met nutriënten en of er hier de laatste tien jaar veranderingen in zijn optreden.

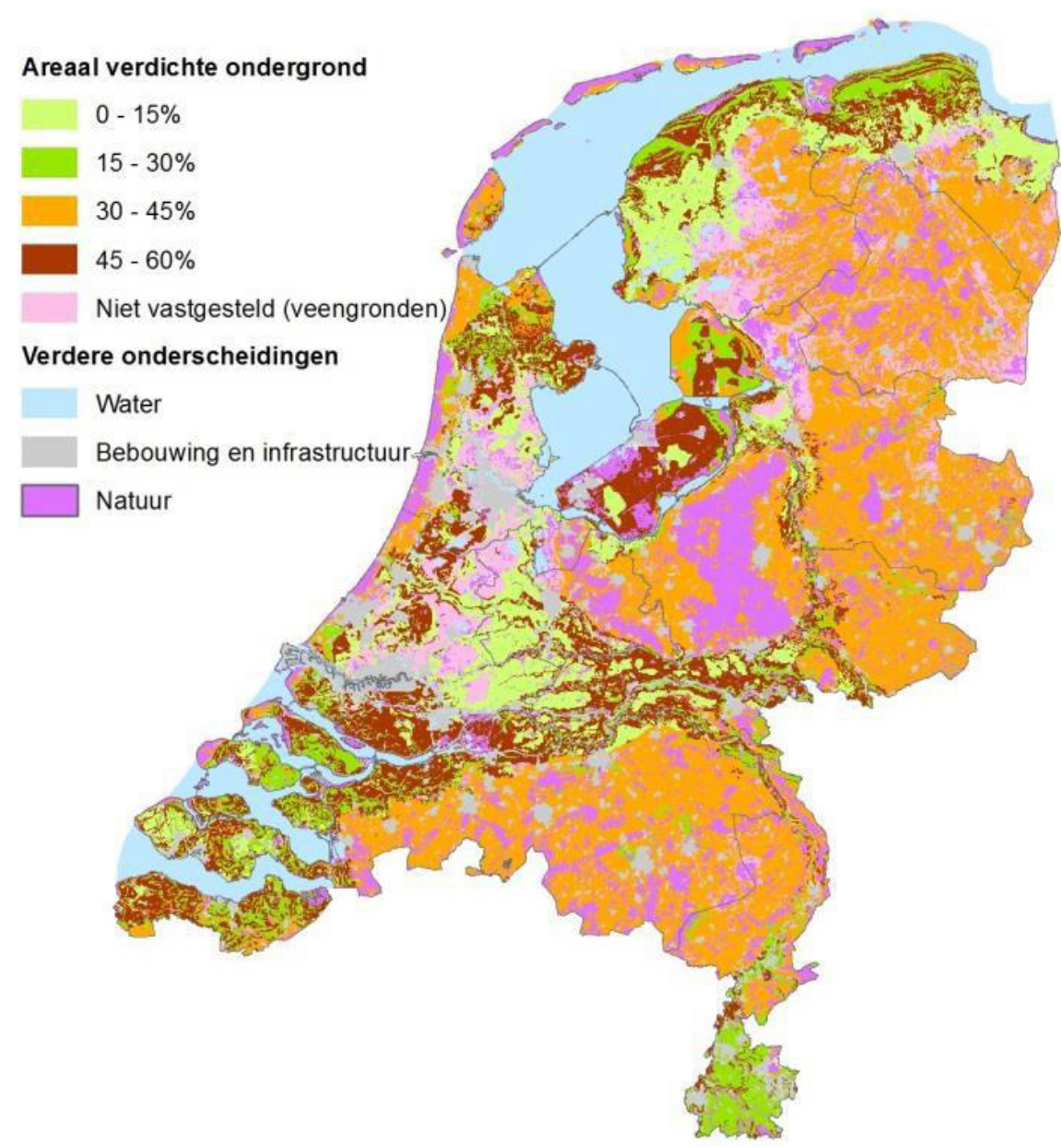

Figuur 32 Oververdichting ondergrond in 2013 gebaseerd op dichtheden gemeten op 128 punten in Nederland (Van den Akker en Hendriks, 2015; Brus en Van den Akker, 2018).

\subsection{Bodemleven}

$\mathrm{Er}$ is een groot aantal groepen organismen in bodems aanwezig: van mollen, regenwormen, kevers, nematoden tot bacteriën en schimmels. Bodemorganismen hebben een belangrijke rol in de koolstof- en stikstofkringloop in bodem en, in mindere mate, in de fosfaatkringloop in bodems. Bodemorganismen kunnen zowel positieve als negatieve effecten hebben op de uitspoeling van nutriënten naar grond- en oppervlaktewater. Bodemorganismen kunnen de bodemstructuur verbeteren (wormgangen, verkitting van bodemdeeltjes door bacteriën) en daarmee de gewasgroei verbeteren. Afbraak van nitraat dat uit de wortelzone is uitgespoeld door denitrificerende bacteriën zorgt ervoor dat dit nitraat niet het grond- en oppervlaktewater bereikt. Anderzijds kan stikstofmineralisatie tijdens afbraak van organische stof in de bodem leiden tot meer nitraatuitspoeling indien de mineralisatie plaatsvindt buiten de groeiperiode van het gewas. Ziekten van gewassen en plagen veroorzaakt door bodemorganismen zoals schimmels, bacteriën, nematoden en emelten kunnen leiden tot een lagere opname van nutriënten en daardoor tot een verhoogd risico op uitspoeling. 
Regenwormen vormen een belangrijk deel van het bodemleven en hebben grote invloed op de koolstof- en nutriëntenkringlopen onder de grond. Regenwormen zijn een belangrijk 'stapelvoedsel' voor volwassen weidevogels. Uit een modelstudie van Rutgers et al. (2016) werd geschat dat er voor grote delen van het land zo'n 300 tot 600 exemplaren per $\mathrm{m}^{2}$ voorkomen. Vergeleken met omringende landen zijn dat hoge cijfers (in veel gebieden in Frankrijk en Duitsland komen de aantallen niet boven de 200 wormen per $\mathrm{m}^{2}$; Rutgers et al., 2016). Hierbij moet worden opgemerkt dat er grote onzekerheden zijn in dezen en dat regenwormpopulaties sterk fluctueren in de tijd (Timmerman et al., 2006). De CDM (2020i) concludeert dat er geen eenduidige aanwijzingen zijn in de literatuur dat de bemestingsmaatregelen uit het mestbeleid (gebruiksnormen, emissiearme mesttoediening, en periode van mesttoediening) een effect hebben op de hoeveelheid regenwormen in de bodem die voor weidevogels beschikbaar zijn.

Van der Putten (2019) geeft aan dat intensivering van het landgebruik leidt tot een achteruitgang van de bodembiodiversiteit en dat hierdoor bacterie-gedomineerde bodems ontstaan die goed zijn voor hoge gewasopbrengsten, maar slecht presteren in het vasthouden van nutriënten, het tegengaan van nitraatuitspoeling, koolstofvastlegging en bodemstructuur. Hij geeft ook aan dat trends van bodembiodiversiteit in de tijd moeilijk zijn te koppelen aan veranderende milieufactoren, doordat zo veel factoren tegelijk veranderen. Verder concludeert hij dat er voor landbouwgronden geen referentiesysteem bestaat voor bodembiodiversiteit, met daaraan gekoppeld de gevolgen voor ecosysteemprocessen en -diensten (zoals verminderen van uitspoeling van nutriënten). Gemeten waarden van bodembiodiversiteit in meetnetten zouden dan hieraan getoetst kunnen worden. In een studie van Rutgers et al. (2018) is een bodembiodiversiteitskaart gemaakt van Nederland, gebaseerd op elf bodembiodiversiteitsindicatoren in zowel natuur- als landbouwbodems (Figuur 33). In deze figuur is een lagere biodiversiteit in bouwland (bv. Zeeland en Groningen) ten opzichte van grasland (bv. Friesland) zichtbaar, evenals de verschillen in grondsoort (veen > klei > zand). Of deze verschillen in bodembiodiversiteit van invloed zijn op de uitspoeling van nutriënten is niet bekend. Ook zijn er geen studies gevonden waaruit blijkt dat er veranderingen zijn opgetreden in de bodembiodiversiteit in landbouwgronden gedurende de laatste 10-20 jaar en of die hebben geleid tot veranderingen in uitspoeling van nutriënten.

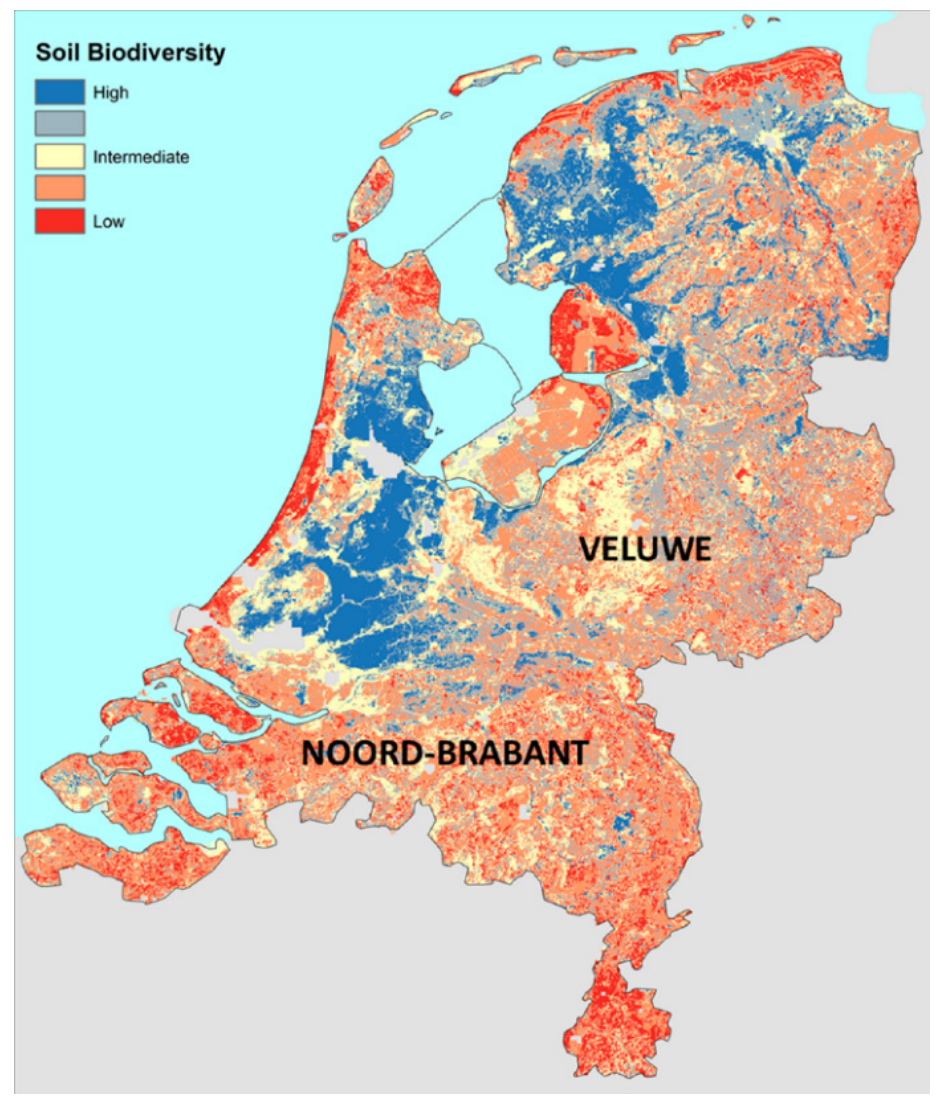

Figuur 33 Bodembiodiversiteit in Nederland, gebaseerd op 11 biodiversiteitsparameters (Rutgers et al., 2018). 


\subsection{Samenvatting}

Langjarige trends laten geen grote veranderingen zien in het gehalte aan organische stof in de bodem. Ook zijn er weinig veranderingen opgetreden in de fosfaattoestand van de bodem. Een slechte chemische bodemvruchtbaarheid kan leiden tot meer nitraatuitspoeling indien er een tekort optreedt van een bepaald nutriënt. De chemische bodemvruchtbaarheid (fosfaat, calcium, magnesium, zuurgraad) van Nederlandse landbouwgronden is in het algemeen goed.

Verdichting van de ondergrond onder de ploegzool is een doorlopend cumulatief proces, dat op de lange duur resulteert in een blijvend homogeen verdichte ondergrond. Een goed opgezette, systematische inventarisatie naar bodemverdichting onder de ploegzool heeft in Nederland nooit plaatsgevonden. Een beperkte inventarisatie geeft aan dat $45 \%$ van de Nederlandse landbouwgronden oververdicht is. Verdichting van landbouwgrond heeft een effect op de beworteling, infiltratiecapaciteit, zuurstofvoorziening en biologische processen en daarmee ook op de hoeveelheid nutriënten die uitspoelt. Het is niet bekend of veranderingen in bodemverdichting hebben geleid tot veranderingen in de belasting van grond- en oppervlaktewater met nutriënten gedurende de laatste tien jaar.

$\mathrm{Er}$ is een groot aantal groepen organismen in bodems aanwezig. Regenwormen vormen een belangrijk deel van het bodemleven en hebben grote invloed op de koolstof- en nutriëntenkringlopen onder de grond. Er zijn geen duidelijke aanwijzingen in de literatuur dat de bemestingsmaatregelen uit het mestbeleid (gebruiksnormen, emissiearme mesttoediening en periode van mesttoediening) een effect hebben op de hoeveelheid regenwormen in de bodem die voor weidevogels beschikbaar zijn. Bodemorganismen kunnen zowel positieve als negatieve effecten hebben op de uitspoeling van nutriënten naar grond- en oppervlaktewater. Resultaten van metingen in een meetnet van bodemkwaliteitsparameters laat zien dat er verschillen zijn in bodembiodiversiteit tussen grasland en bouwland en tussen grondsoorten. Of deze verschillen in bodembiodiversiteit van invloed zijn op de uitspoeling van nutriënten is niet bekend. Ook zijn er geen studies gevonden waaruit blijkt dat er veranderingen zijn opgetreden in de bodembiodiversiteit in landbouwgronden gedurende de laatste 10-20 jaar die hebben geleid tot veranderingen in uitspoeling van nutriënten. 


\section{$8 \quad$ Kwaliteit van grond- en oppervlaktewater}

\subsection{Monitoring van waterkwaliteit}

In dit hoofdstuk worden de resultaten gepresenteerd van nutriëntenconcentraties in water dat uit landbouwpercelen spoelt en resultaten van de grond- en oppervlaktewaterkwaliteit. In het kader van de Nitraatrichtlijn zijn lidstaten verplicht de effecten van de maatregelen op de kwaliteit van grond- en oppervlaktewater te monitoren. In het Landelijk Meetnet effecten Mestbeleid (LMM) wordt op circa 450 landbouwbedrijven jaarlijks zowel de landbouwpraktijk als de waterkwaliteit gemonitord. Het LMM is ontwikkeld om het effect van het Nederlandse mestbeleid op de nutriëntenuitspoeling, en vooral de nitraatuitspoeling, uit landbouwbronnen naar het grond- en oppervlaktewater te meten en de effecten van veranderingen in de landbouwpraktijk op de uitspoeling te volgen (Fraters et al., 2020). De monitoringprogramma's zijn gericht op de belangrijkste Nederlandse hoofdgrondsoortregio's: de zand-, de löss-, de klei- en de veenregio. De monitoring van de waterkwaliteit van het water dat uitspoelt uit de wortelzone vindt plaats door het nemen van monsters:

- Van de bovenste meter van het freatisch grondwater;

- Van bodemvocht in de onverzadigde zone onder de wortelzone tussen 1,5 en 3,0 m onder het maaiveld als het grondwater dieper zit dan $5 \mathrm{~m}$ beneden maaiveld (zoals in lössgrond);

- Van het drainwater, voor bedrijven in de kleiregio die voldoende gedraineerd zijn (Fraters et al., 2020).

Het Landelijk Meetnet Grondwaterkwaliteit (LMG) bestaat uit ongeveer 350 meetlocaties die zijn verspreid over heel Nederland (Fraters et al., 2020). Op elke locatie worden grondwatermonsters genomen op diepten van 5-15 m en 15-30 m onder het grondoppervlak.

Het Meetnet Nutriënten Landbouwspecifiek Oppervlaktewater (MNLSO) is in 2010-2012 opgezet om de waterkwaliteit te monitoren op het gebied van nutriënten in landbouwspecifiek oppervlaktewater (Buijs et al., 2020; Buijs, 2020; Rozemeijer at al., 2014). In MNLSO zijn bestaande meetlocaties van alle waterschappen geselecteerd waarvan verwacht wordt dat landbouw de belangrijkste antropogene bron van nutriënten is. Bij de keuze van de meetlocaties is rekening gehouden met het optreden van zo min mogelijk kwel en een minimale beïnvloeding van de nutriëntenbelasting door inlaatwater. Dit meetnet valt onder de verantwoordelijkheid van de waterschappen en de meetpunten zijn vaak gelegen in watergangen die de zomerperiode niet droog vallen. Onderscheid wordt gemaakt tussen meetpunten voor een toestandsbeoordeling en een trendbepaling.

\subsection{Nitraatconcentratie in het water dat uit de wortelzone spoelt}

De nitraatconcentratie in het water dat uitspoelt uit de wortelzone op landbouwbedrijven in de LMMregio's laat langjarig een dalende trend zien, waarbij de sterkste daling in de jaren negentig van de vorige eeuw is opgetreden (Figuur 34). Er is in 2018-2019 duidelijk sprake van een verandering ten opzichte van de stabiele of (licht) dalende nitraatconcentratie in de laatste tien jaar (Figuur 34; Figuur 35). In 2019 lag de gemiddelde nitraatconcentratie in de zand- en lössregio boven de 50 mg/l en in de kleiregio iets onder de $50 \mathrm{mg} / \mathrm{l}$. Om de effecten van het mestbeleid beter te kwantificeren, hebben Boumans en Fraters (2017) een statistisch model ontwikkeld om de nitraatconcentratie te corrigeren voor externe omstandigheden, zoals het weer. De zogeheten gestandaardiseerde nitraatconcentratie is in 2019 iets toegenomen voor zand- en kleigronden, maar veel minder dan de gemeten concentratie (Fraters et al., 2020; Figuur 51). Dit duidt erop dat de stijging in de gemeten nitraatconcentratie in 2019 voor een groot deel door droogte in 2018 is veroorzaakt. 
In alle zandgebieden is de nitraatconcentratie in het uitspoelingswater gestegen in 2018; de concentratie in het gebied zuid is hoger dan in de gebieden zand-midden en -noord (Figuur 36). De verschillen in nitraatconcentratie tussen de drie zandgebieden zijn voor een groot deel te verklaren uit de verdeling van de grondwatertrappen en grondsoorten die er voorkomen (er zijn relatief meer uitspoelingsgevoelige zandgronden in de zuidelijke zandregio) en doordat het aandeel grasland in het de zuidelijke zandregio lager is dan in de andere zandgebieden. Volgens de BasisRegistratiePercelen van 2018 was 39\% van het landbouwareaal in regio zand-zuid in gebruik als grasland, voor zandnoord bedraagt dit $49 \%$ en voor zand-midden $70 \%$.

De gemiddelde nitraatconcentratie van bedrijven met een derogatie, voor het grootste deel bestaande uit melkveebedrijven met minimaal $80 \%$ grasland, laat vanaf 2007 een dalende trend zien en lag in de periode 2014-2018 voor alle grondsoorten op of onder de $50 \mathrm{mg}$ nitraat per L (Figuur 35). Na het droge jaar 2018 is de nitraatconcentratie van derogatiebedrijven in de lössregio gestegen tot boven de $50 \mathrm{mg}$ nitraat per $\mathrm{L}$ en die van derogatiebedrijven in de regio's zand-midden en zand-zuid met een derogatie van $230 \mathrm{~kg} \mathrm{~N}$ per ha (Overijssel, Gelderland, Utrecht, Noord-Brabant of Limburg) was ongeveer gelijk aan $50 \mathrm{mg}$ nitraat per L. De gemiddelde nitraatconcentratie van derogatiebedrijven in de overige zandregio's en in de klei- en veenregio's ligt onder de 50 mg nitraat per L.

Er zijn nog geen gegevens gepubliceerd over de nitraatconcentratie op akkerbouw- en melkveebedrijven op zandgrond in 2019. De langjarige trend tot 2018 laat gemiddeld duidelijk hogere nitraatconcentraties zien op akkerbouwbedrijven dan op melkveebedrijven (Figuur 37). De nitraatconcentraties op melkveebedrijven zijn - ondanks de hogere stikstofoverschotten - lager dan op akkerbouwbedrijven. In grasland is de beschikbaarheid van snel afbreekbare organische stof hoger dan op bouwland. Door deze hogere beschikbaarheid is de denitrificatie hoger op grasland dan op bouwland (Velthof, 2003). De concentraties op akkerbouwbedrijven op zandgrond zijn in 2016, 2017 en 2018 iets lager dan in de periode 2005-2015; dit zou veroorzaakt kunnen zijn door maatregelen die in het Vijfde Actieprogramma zijn genomen (zie paragraaf 2.2), maar monitoring over een langere periode is nodig om hierover harde uitspraken te doen.

Metingen in het kader van LMM laten zien dat de nitraatconcentratie in grasland op zandgrond lager is dan op maïsland in de periode 2009-2015 (Figuur 38). Maïsland heeft een lagere stikstofopnamecapaciteit, een kortere periode waarin stikstof wordt opgenomen en een lagere denitrificatiecapaciteit dan grasland, waardoor de nitraatuitspoeling naar het grondwater in maïsland hoger is dan in grasland. Verder wordt een deel van snijmaïs geteeld na het scheuren van grasland; de hoge stikstofmineralisatie in gescheurd grasland kan tot een toename van nitraatuitspoeling leiden. Hierbij moet wel worden gemeld dat de stikstofgebruiksnorm voor maïsland in het zuidelijke zandgebied in het Vijfde Actieprogramma met 20\% (van 140 naar $112 \mathrm{~kg} / \mathrm{ha}$ ) is verlaagd en dat er strengere eisen zijn gesteld aan de teelt van vanggewassen na de teelt van maïs. Mogelijk is het verschil in nitraatconcentratie in het bovenste grondwater tussen grasland en maïsland nu kleiner.

De gegevens van de waterkwaliteit in de winter 2019/2020 uit het LMM zijn nog niet beschikbaar. Het RIVM heeft op verzoek van de CDM in het kader van een advies over droogte in 2020 wel een indicatie gegeven van de nitraatconcentratie in grond- en oppervlaktewater in de winter 2019/2020 (CDM, 2020f). In het grondwater stijgen de nitraatconcentraties in alle regio's sinds de metingen van winter 2017-2018, behalve in de Veenregio; daar schommelt de concentratie licht en is geen sprake van een stijging. De voorlopige resultaten van de metingen in winter 2019-2020 in de zandregio laten een verdere forse stijging van nitraatconcentratie te zien (met circa $20 \mathrm{mg}$ per $\mathrm{L}$ ). De voorlopige resultaten van de metingen in winter 2019-2020 in de kleiregio laten ook zien dat de nitraatconcentratie verder is gestegen ten opzichte van het voorgaande jaar. In de lössregio stijgen de nitraatconcentraties in het bodemvocht in de winters van 2017-2018 en 2018-2019, en voorlopige resultaten van de metingen die zijn uitgevoerd in de winter van 2019-2020 laten een verdere stijging zien. Voorlopige resultaten van de metingen in de winter van 2019-2020 in veengebied laten zien dat de nitraatconcentraties in het grondwater weer beginnen te dalen na de toename in 2018-2019. 


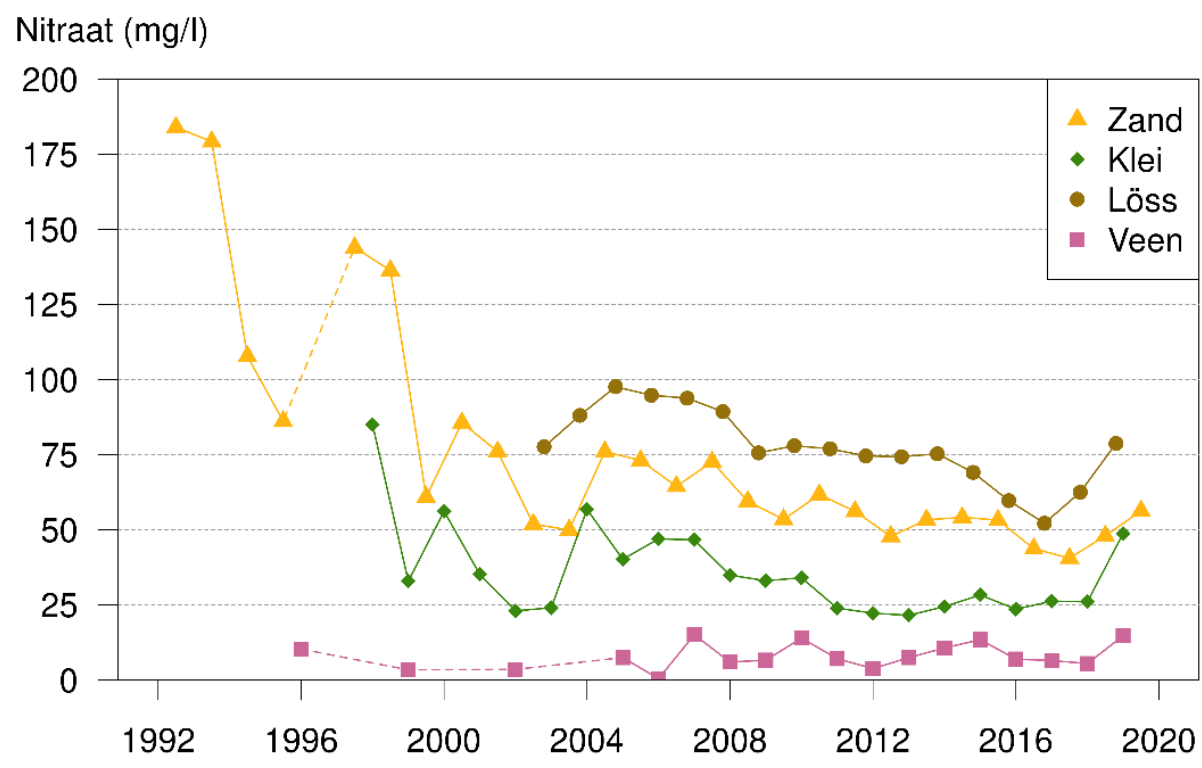

Figuur $34 \quad$ Nitraatconcentraties (als $\mathrm{NO}_{3}$ in $\mathrm{mg}$ per $\mathrm{L}$ ) in het water dat uitspoelt uit de wortelzone op landbouwbedrijven per regio in de periode 1992-2019. Jaargemiddelde van areaal-gewogen gemeten concentraties (Fraters et al., 2020).

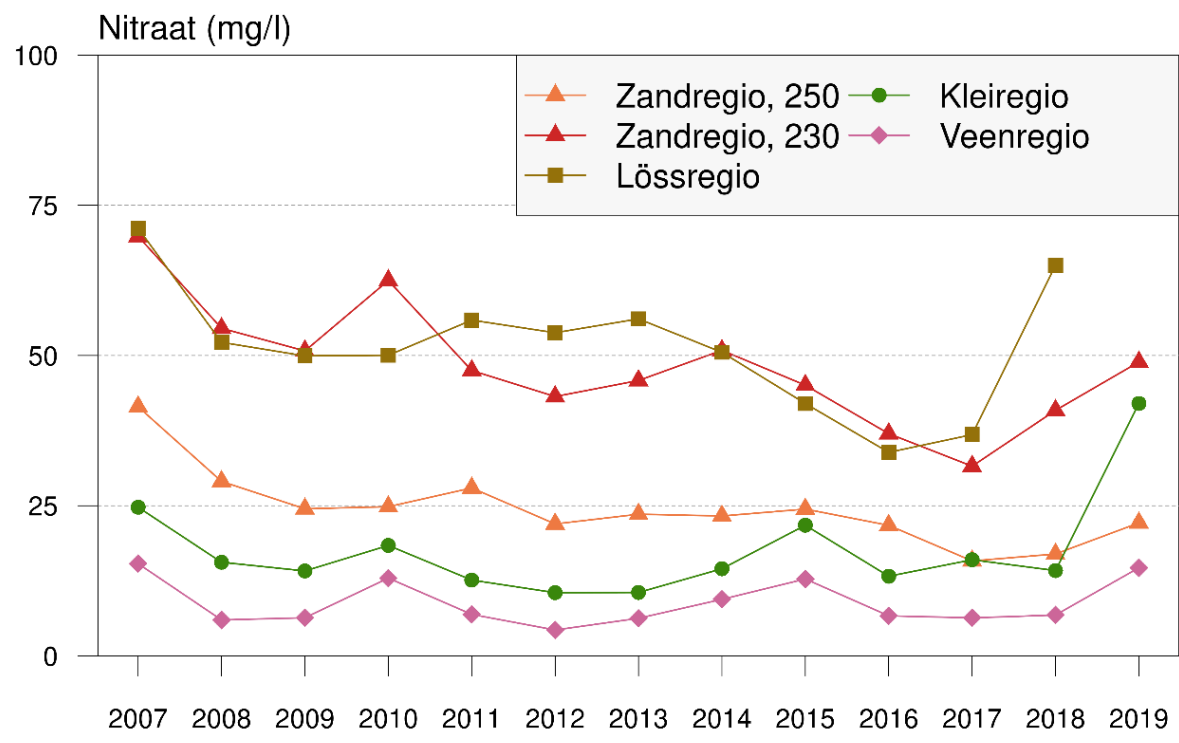

Figuur 35 Gemiddelde nitraatconcentratie in water uitspoelend uit de wortelzone op derogatiebedrijven (grootste deel bestaande uit melkveebedrijven met minimaal $80 \%$ grasland) in de vier grondsoortregio's in de periode 2007-2019 (Lukács et al., 2020). 


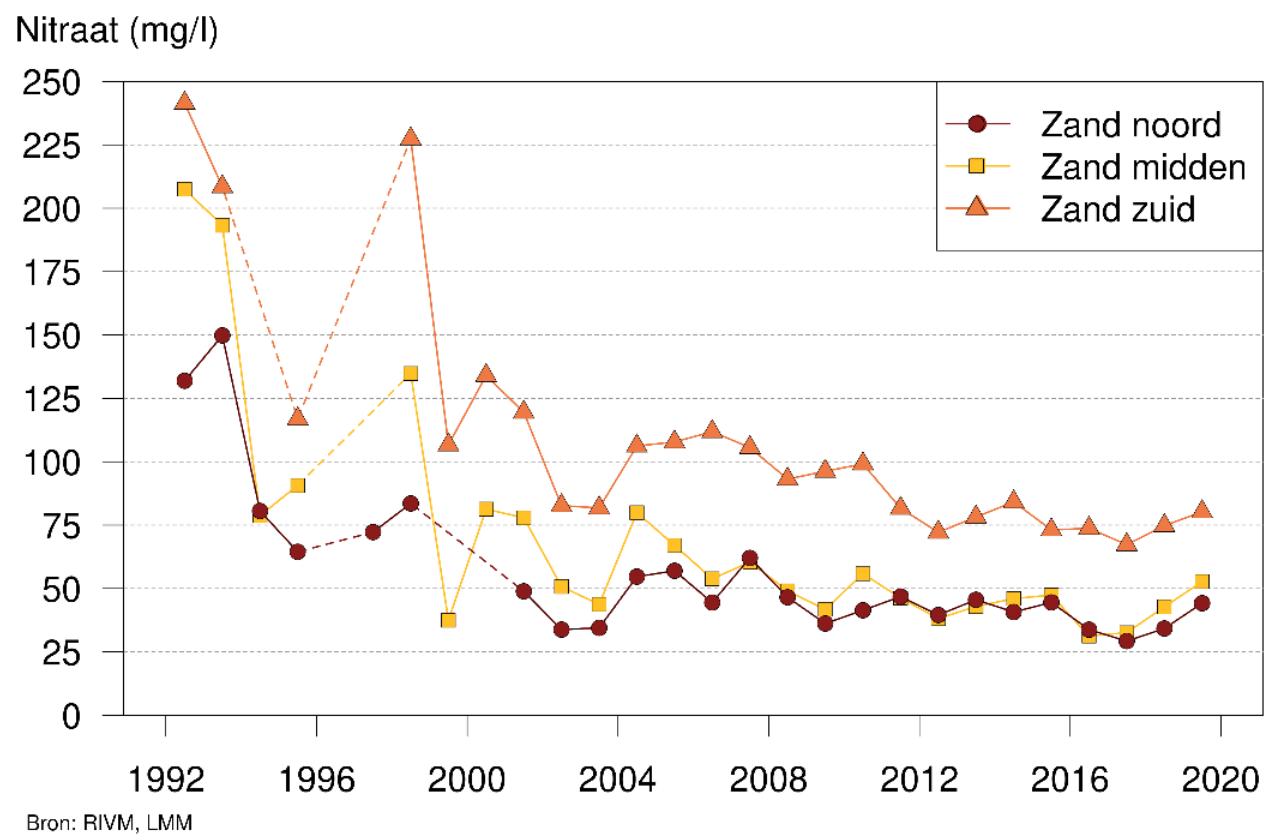

Figuur 36 Nitraatconcentraties (areaal-gewogen jaargemiddelde van gemeten concentratie in mg per $\mathrm{L}_{\text {als }} \mathrm{NO}_{3}$ ) in het water dat uitspoelt uit de wortelzone op landbouwbedrijven in de gebieden zandnoord, zand-midden en zand-zuid in de periode 1992-2019 (Fraters et al., 2020).

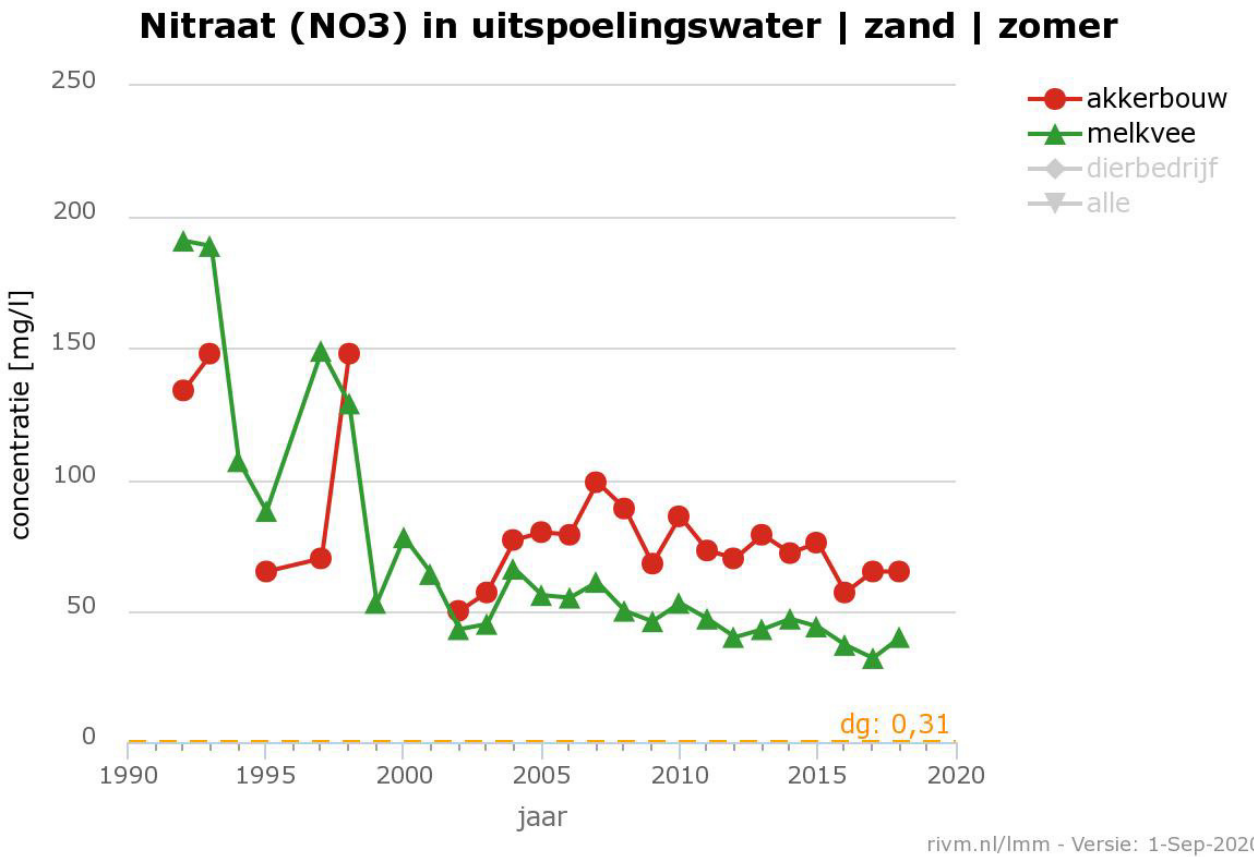

Figuur 37 Nitraatconcentratie in het bovenste grondwater van akkerbouwbedrijven en melkveebedrijven in de Zandregio (Bron: LMM).

De fosfaatconcentratie die uitspoelt uit de wortelzone lijkt sinds 2008 geleidelijk toe te nemen (Figuur 39). De fosfaatconcentraties zijn weliswaar laag (lager dan 0,2 mg P-totaal per L), maar de stijging zou kunnen wijzen op doorslag van fosfaat in fosfaatverzadigde bovengronden. De stijging vond echter op slechts enkele bedrijven plaats, zodat de onzekerheid groot is. 


\section{Nitraat $(\mathrm{mg} / \mathrm{l})$}

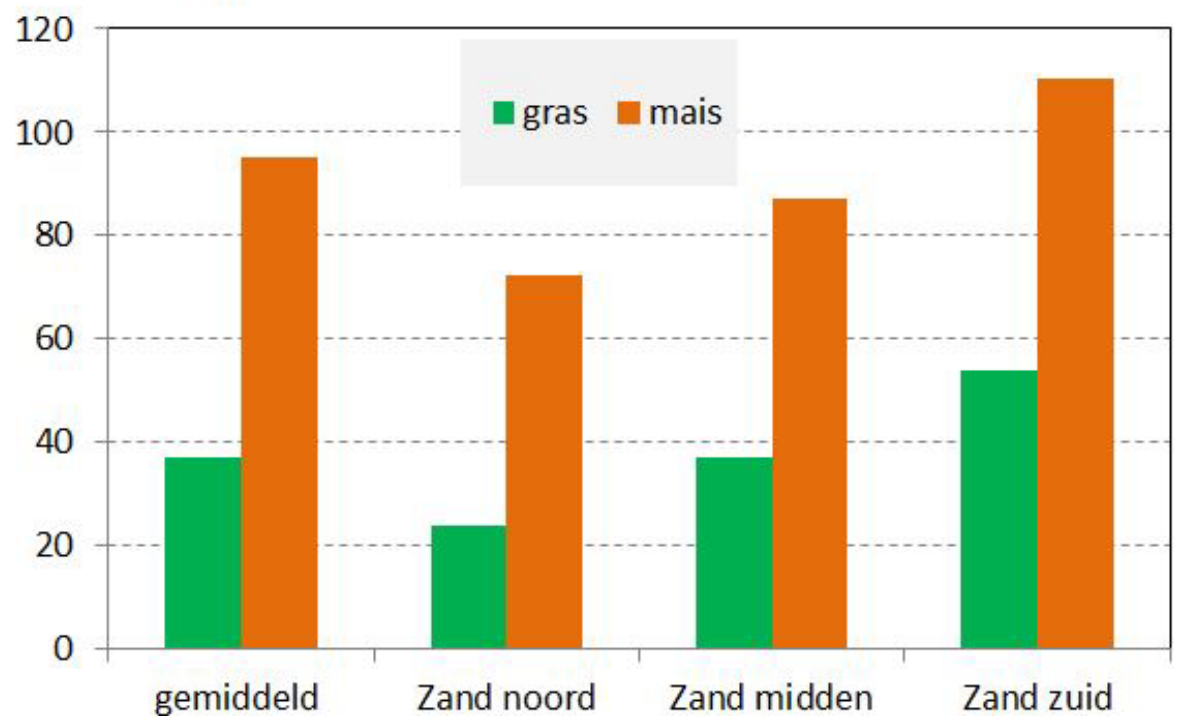

Figuur 38 Nitraatconcentratie in het bovenste grondwater onder gras- en maïsland op zandgronden voor de jaren 2009-2015, bepaald met een nitraatsneltest (Nitracheck); de zandgronden zijn uitgesplitst naar zandgebied (Bron: $L M M^{\mathbf{1 8}}$ ).

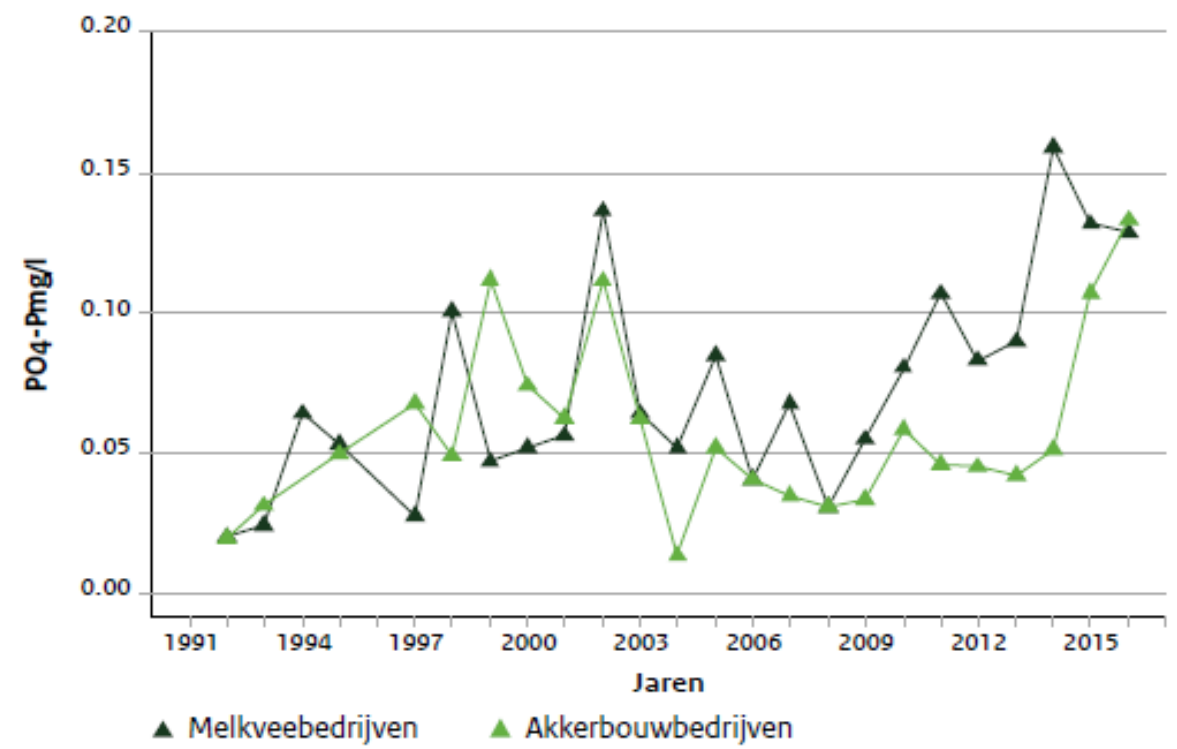

Figuur 39 Fosfaatconcentraties sinds 1992 in het bovenste grondwater op twee verschillende bedrijfstypen in de zandregio (Bron: LMM, LMM Nieuwsbrief november 2018).

\subsection{Nitraatconcentratie in het diepere grondwater}

De nitraatconcentratie in het middeldiepe grondwater $(5-15 \mathrm{~m})$ laat een dalende trend zien voor zandgronden en ligt gemiddeld voor klei-, veen- en zandregio's onder de $50 \mathrm{mg}$ nitraat per L (Figuur 40). In de zuidelijke zandregio ligt de nitraatconcentratie op 5-15 m diepte boven de $50 \mathrm{mg}$ nitraat per L (Figuur 41). Of de toename van de nitraatconcentratie in het uitspoelingswater uit de wortelzone in recente jaren (Figuur 34) zal leiden tot een toename van de nitraatconcentratie in diepere lagen, is afhankelijk van hydrologische processen en afbraak van nitraat in de ondergrond door denitrificatie (Broers et al., 2004; Broers \& Van der Grift, 2004). Denitrificatie in de ondergrond

\footnotetext{
${ }^{18}$ https://www.rivm.nl/Onderwerpen/L/Landelijk_Meetnet_effecten_Mestbeleid/Nieuwsbrieven/Nieuwsbrieven_Landelijk_Me etnet_effecten_Mestbeleid/Verschil_in_nitraatconcentratie?utm_source=Measuremail\&utm_medium=email\&utm_campaig $\mathrm{n}=\mathrm{LMM} \% 20$ nieuwsbrief\%20(NL)
} 
kan optreden als er pyriet of organische stof (veenlaagjes) aanwezig is. Op 15-30 m diepte ligt de gemiddelde nitraat-concentratie in de klei-, veen- en zandregio's onder de $10 \mathrm{mg}$ nitraat per L (Fraters et al., 2020).

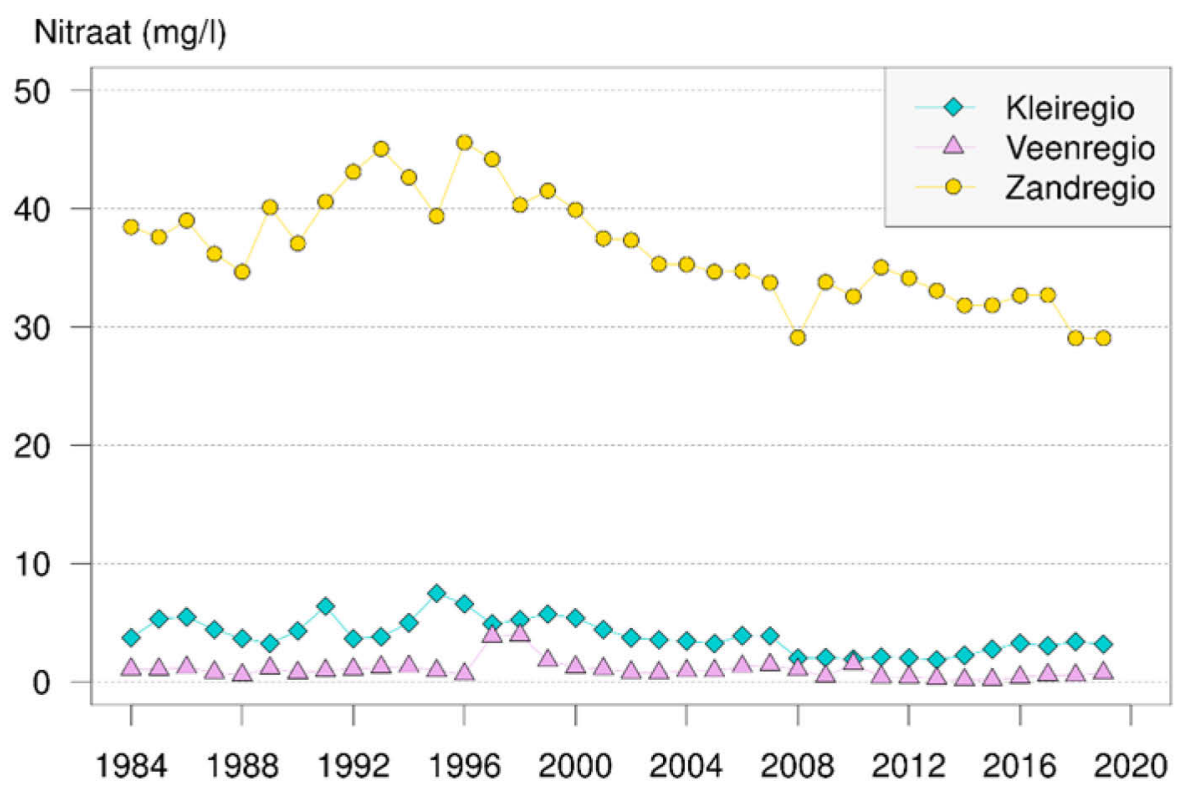

Figuur 40 Gemiddelde jaarlijkse nitraatconcentratie ( $m g$ per $L$ ) in het grondwater in landbouwgebieden op een diepte van 5-15 m onder maaiveld per regio (Fraters et al., 2020).

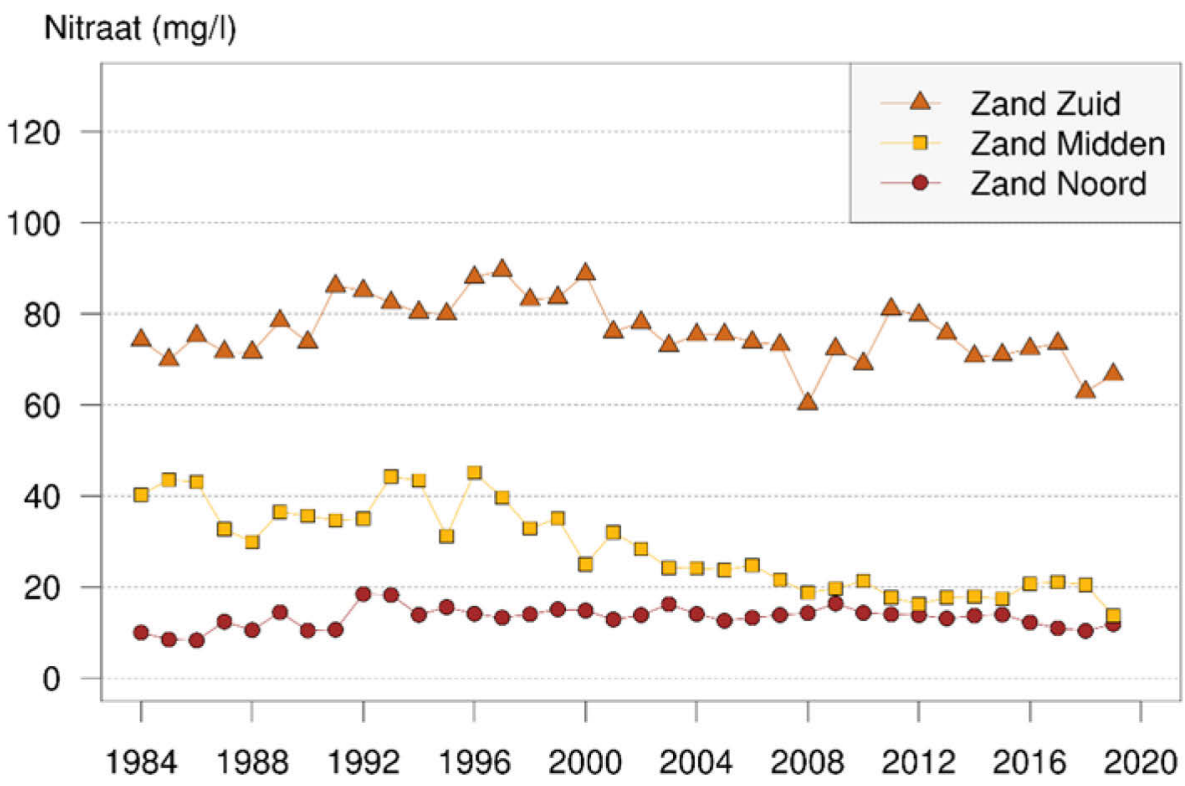

Figuur 41 Nitraat in het grondwater onder landbouw op een diepte van 5-15 m onder maaiveld per zandgebied (Fraters et al., 2020). 


\subsection{Stikstof- en fosforconcentraties in het oppervlaktewater}

\subsubsection{Normen voor het oppervlaktewater}

Het doel van de Kaderrichtlijn Water (KRW) is het bereiken en behouden van een goede chemische en biologische kwaliteit van het oppervlaktewater. Hierbij is de ecologische waterkwaliteit leidend; de normen voor stikstof en fosfor kunnen in elk watertype anders zijn, omdat elk watertype andere ecologische doelen en een andere relatie tussen chemie en ecologie heeft. Door Van der Molen et al. (2012) en Evers et al. (2012) zijn stikstof- en fosfaatnormen afgeleid voor de verschillende type KRWlichamen.

Voor de kleinere wateren die niet als KRW-waterlichaam zijn aangewezen en die ook wel 'overige wateren' worden genoemd, is een methodiek ontwikkeld die is afgeleid van de KRW-systematiek voor de KRW-waterlichamen (Buijs et al., 2020; Rozemeijer et al., 2014). Deze methodieken zijn door de waterbeheerders gebruikt voor het afleiden van de nutriëntennormen voor de MNSLO-meetlocaties die niet in een KRW waterlichaam liggen ('waterschapsnormen').

\subsubsection{Nitraatconcentratie in het oppervlaktewater}

De gemiddelde nitraatconcentratie in het slootwater op LMM- en de derogatiebedrijven binnen LMM laat een sterke stijging zien in de winter 2018/2019 ten opzichte van eerdere jaren (Figuur 42; Figuur 43). In de zandregio is de nitraatconcentratie in het slootwater tot boven de $50 \mathrm{mg}$ nitraat per $\mathrm{L}$ gestegen. Op bedrijven met een derogatie van $230 \mathrm{~kg} \mathrm{~N}$ per ha is de nitraatconcentratie in de zuidelijke zandregio gestegen tot gemiddeld bijna $70 \mathrm{mg}$ nitraat per L; die in de overige zandregio's (derogatie van $250 \mathrm{~kg} \mathrm{~N}$ per ha) is gestegen tot iets boven de $30 \mathrm{mg}$ nitraat per $\mathrm{L}$.

Het RIVM geeft aan dat de nitraatconcentraties in het drainwater in de winter 2019-2020 afnemen ten opzichte van 2018-2019, maar dat de concentratie nog niet op het niveau van 2017-2018 is (CDM, 2020f). Opvallend is dat nitraatconcentraties in het grondwater blijven stijgen (behalve in veen) en dat de nitraatconcentraties in het drainwater afnemen in de winter 2019-2020 ten opzichte van 2018-2019. Mogelijk komt deze afname in het drainwater door het natte najaar in 2019. Het feit dat de nitraatconcentraties in het drainwater, in tegenstelling tot die in het grondwater, wel lager zijn in 2019-2020 dan in 2018-2019, geeft ook een indicatie dat na-ijleffecten een rol spelen. De nitraatconcentratie in het drainwater reageert sneller op veranderingen in nitraatuitspoeling na het groeiseizoen dan het zich in diepere bodemlagen bevindende grondwater. Mogelijk had een deel van het in de winter 2018-2019 uitgespoelde nitraat het grondwater nog niet bereikt en is het in de winter 2019-2020 verder uitgespoeld.

De wintergemiddelde nitraatconcentratie in zoete oppervlaktewateren laat een dalende trend zien (Figuur 44). In de figuur wordt het wintergemiddelde voor een halfjaar getoond. In 2018-2019 was het uitspoelingsseizoen erg kort. In de periode september tot en met november 2018 waren de concentraties in het MNLSO dus nog erg laag (Buijs, 2020). Op maandbasis is in MNLSO echter hetzelfde effect van de droogte in 2018 te zien als in LMM; vanaf december 2018 (als de uitspoeling op gang komt) zijn de concentraties in het MNLSO ook hoog (Buijs, 2020). 


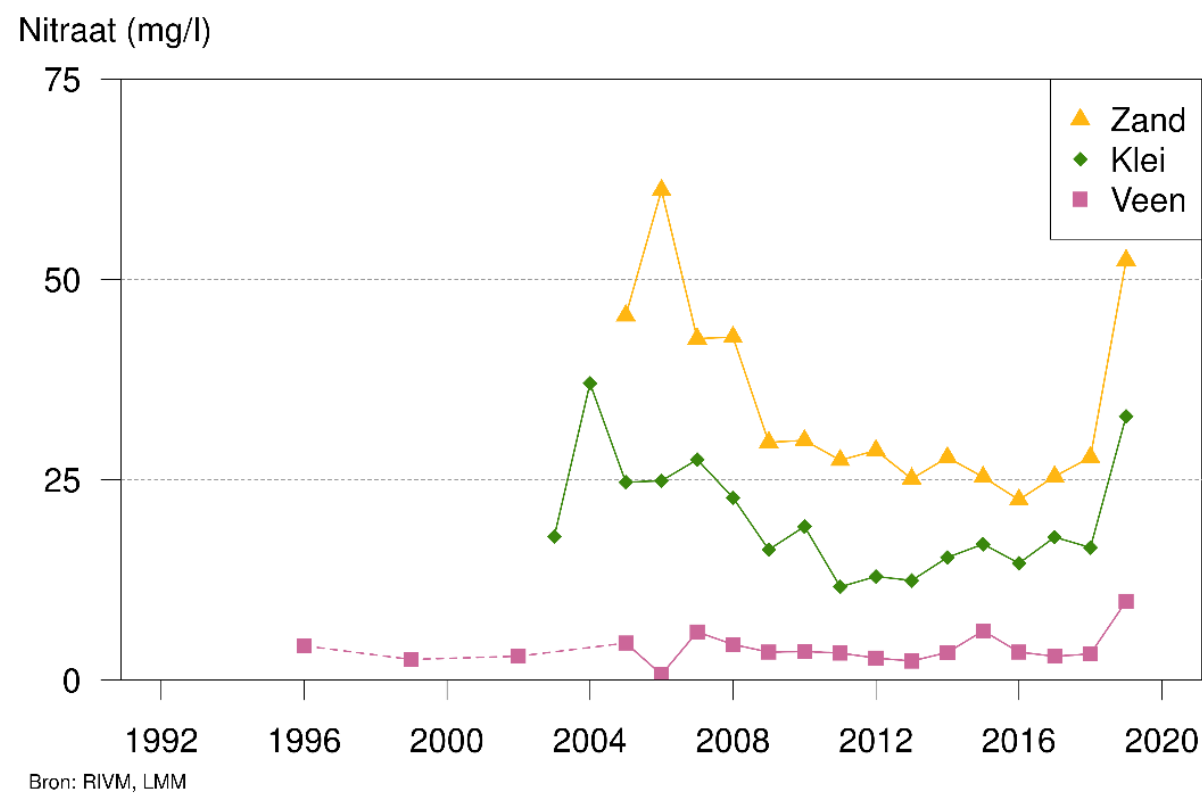

Figuur 42 Nitraatconcentraties (areaal-gewogen wintergemiddelde, als $\mathrm{NO}_{3}$ in $\mathrm{mg}$ per $\mathrm{L}$ ) in het slootwater op landbouwbedrijven van LMM per regio in de periode 1992-2019 (Fraters et al., 2020).

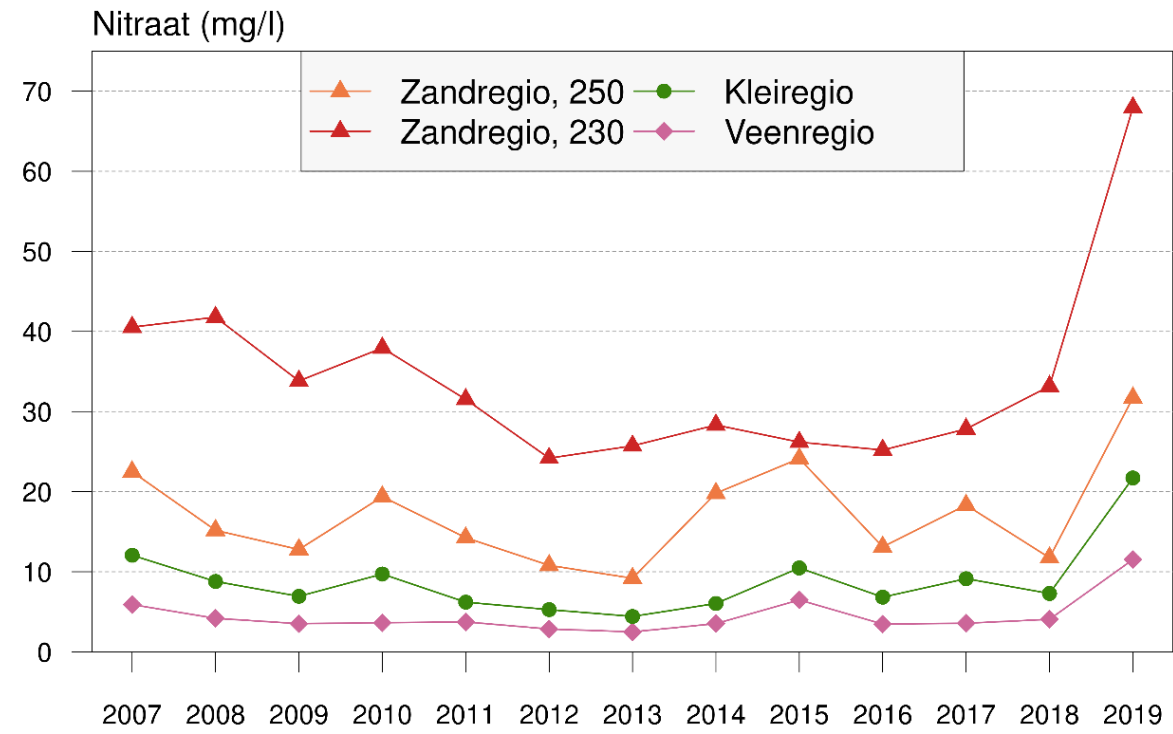

Figuur 43 Gemiddelde nitraatconcentratie in slootwater op derogatiebedrijven in de drie regio's in de periode 2007-2019 (Lukács et al., 2020). 


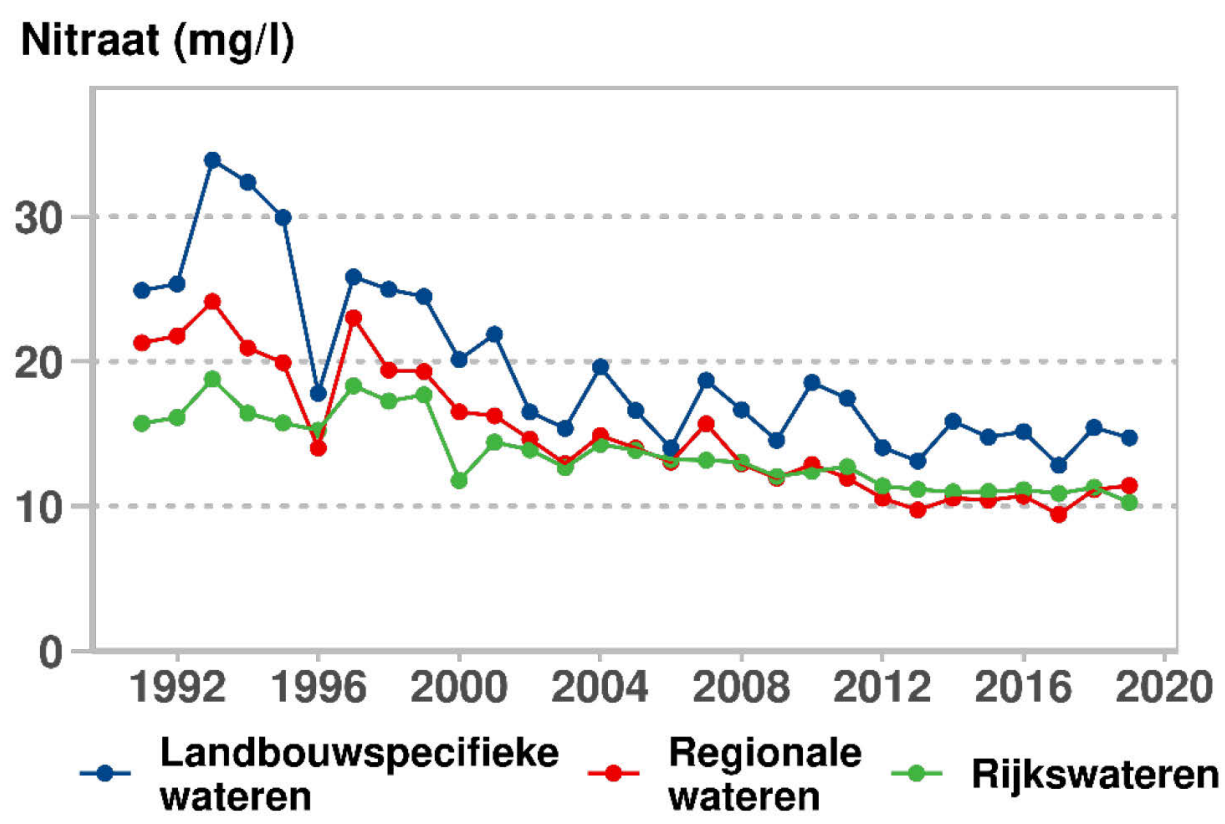

Figuur 44 Wintergemiddelde nitraatconcentratie (in $\mathrm{mg} \mathrm{NO}_{3} / \mathrm{I}$ ) in zoete oppervlaktewateren in de periode 1990-2018; onderscheid KRW Rijkswateren, KRW regionale wateren, Landbouwspecifieke wateren (Fraters et al., 2020).

\subsubsection{Stikstof- en fosforconcentraties in oppervlaktewater}

De stikstofconcentratie (zomergemiddelde $\mathrm{N}$-totaal) in zoete wateren laat een langjarige dalende trend zien (Figuur 45). Voor de $\mathrm{N}$-totaalconcentratie laat ruim $87 \%$ van de MNLSO-locaties een significante neerwaartse trend zien en voor P-totaal is dit $53 \%$ voor de gehele periode vanaf begin jaren ' 90 . De concentratie N-totaal in landbouwspecifieke wateren is relatief laag vanaf 2017 en er is geen effect van het droge jaar 2018 te zien (Figuur 45). Dit is ook niet te verwachten omdat het effect van een door droogte veroorzaakt hoger stikstofoverschot een vertragingstijd heeft. Voor drainwater wordt een effect binnen een seizoen verwacht, voor nitraatconcentraties in het bovenste grondwater na 1-2 jaar en voor de uitspoeling naar oppervlaktewater via het grondwater na 2-5 jaar. In de zandregio stonden een groot deel van de perceel- en kavelsloten droog in de droge zomer van 2018. MNLSO-locaties zijn gesitueerd in permanent watervoerende waterlopen en het bemonsterde water op deze locaties is in de zomer van 2018 sterker beïnvloed door diep grondwater dan in normale jaren. Ondanks de zorgvuldige selectie van de meetpunten ten aanzien van het criterium waterinlaat kan het niet uitgesloten worden dat een aantal meetpunten in deze periode beïnvloed zijn door de aanvoer van rivierwater. Bij de gemeten fosforconcentraties zijn grote fluctuaties in de tijd zichtbaar, veroorzaakt door uitschieters in fosforconcentraties (Figuur 46).

Voor de jaren 2015 tot en met 2018 zijn de meetgegevens van N-totaal en P-totaal in het MNLSOmeetnet getoetst aan de waterschapsnormen (Figuur 47; Figuur 48; Figuur 49). Het percentage dat aan de norm voldoet, varieert voor stikstof tussen $36 \%$ in 2016 en $49 \%$ in 2018 en voor fosfor tussen $49 \%$ (2016) en 55\% (2015 en 2017). Natte perioden hebben een grote invloed op de zomerconcentraties (Buijs et al., 2020). De zomers van 2016 en 2017 waren relatief nat en die van 2018 droog. De meeste normoverschrijdingen voor N-totaal vonden plaats in de natte zomer van 2016. De droge zomer van 2018 laat minder overschrijdingen zien dan in 2015 en 2016. Voor P-totaal is er geen duidelijke relatie te zien tussen de jaarlijkse neerslag en de concentratie. Voor $\mathrm{N}$-totaal komen normoverschrijdingen in het hele land voor en voor P-totaal treden de meeste normoverschrijdingen op in het westen van het land (Figuur 48). In de kleiregio is het percentage meetlocaties dat aan de N-totaal-norm voldoet hoger dan in de andere grondsoortregio's, behalve in 2018 (Figuur 49). Het percentage meetlocaties dat voldoet aan de P-totaal-norm is het hoogst in de zandregio. In de veenregio is het percentage meetlocaties dat voldoet aan de norm lager dan in de andere regio's, zowel voor $\mathrm{N}$-totaal als P-totaal. 
Het MNLSO is opgezet voor een toestandsbepaling en een trendbepaling. Om een trend te kunnen berekenen, wordt de eis gesteld dat een meetreeks minimaal tien meetjaren moet bevatten, waarvan ten minste vijf jaar in de periode 2011-2018 (Buijs et al., 2020). Bij de trendanalyse van MNLSO worden statistische methoden gekozen die niet gevoelig zijn voor schommelingen tussen individuele jaren. Op grond van statistische analyse zijn neerwaartse trends vastgesteld voor de zomer- en winterconcentraties afzonderlijk, voor de MNLSO-deelgebieden zand, klei en veen, voor de KRWdeelstroomgebieden en voor verschillende meetperioden (Buijs et al., 2020). De enige uitzondering op de dalende trends zijn de P-totaal-concentraties in de stroomgebieden van de Maas en Schelde, die een opwaartse trend laten zien vanaf 2010. De opwaartse trends kunnen vaak niet direct aan de bemestingsintensiteit worden toegeschreven (Buijs et al., 2020). Andere parameters die ook gerelateerd kunnen zijn aan bemesting (nitraat, chloride, sulfaat) laten soms een neerwaartse trend zien op de meetpunten waar een opwaartse trend van de P-totaal-concentratie is vastgesteld. Een toename van bodemverdichting en het vaker voorkomen van hevige regenbuien in de zomerperiode kunnen hebben geleid tot vaker en meer oppervlakkige afspoeling.

\section{Totaal-stikstof (mg/l)}

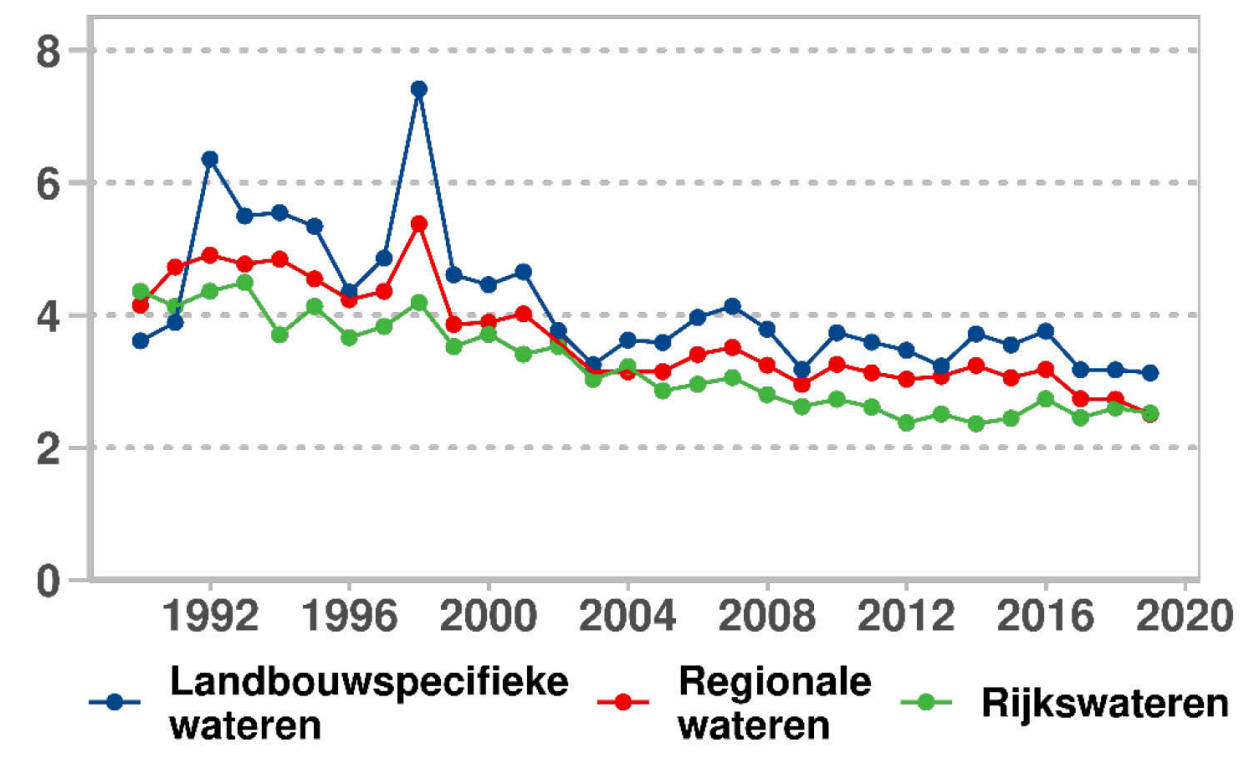

Figuur 45 Totaal-stikstofconcentratie (zomergemiddelde als $\mathrm{N}$ in $\mathrm{mg}$ per $\mathrm{L}$ ) in zoete wateren in de periode 1990-2019 (Fraters et al., 2020). 


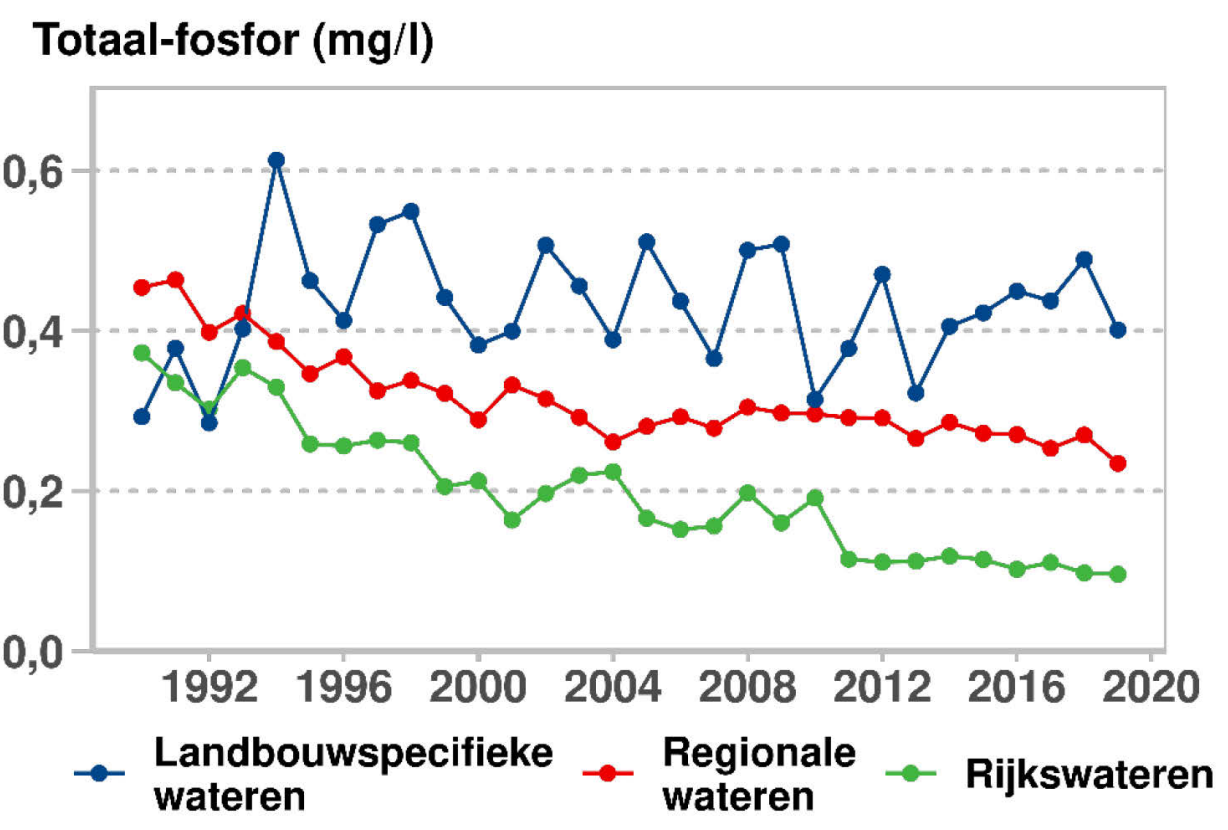

Figuur 46 Totaal-fosforconcentratie (zomergemiddelde) in zoete wateren in de periode 1990-2019 (KRW nationaal, KRW regionaal, Landbouwspecifieke wateren) (Fraters et al., 2020).

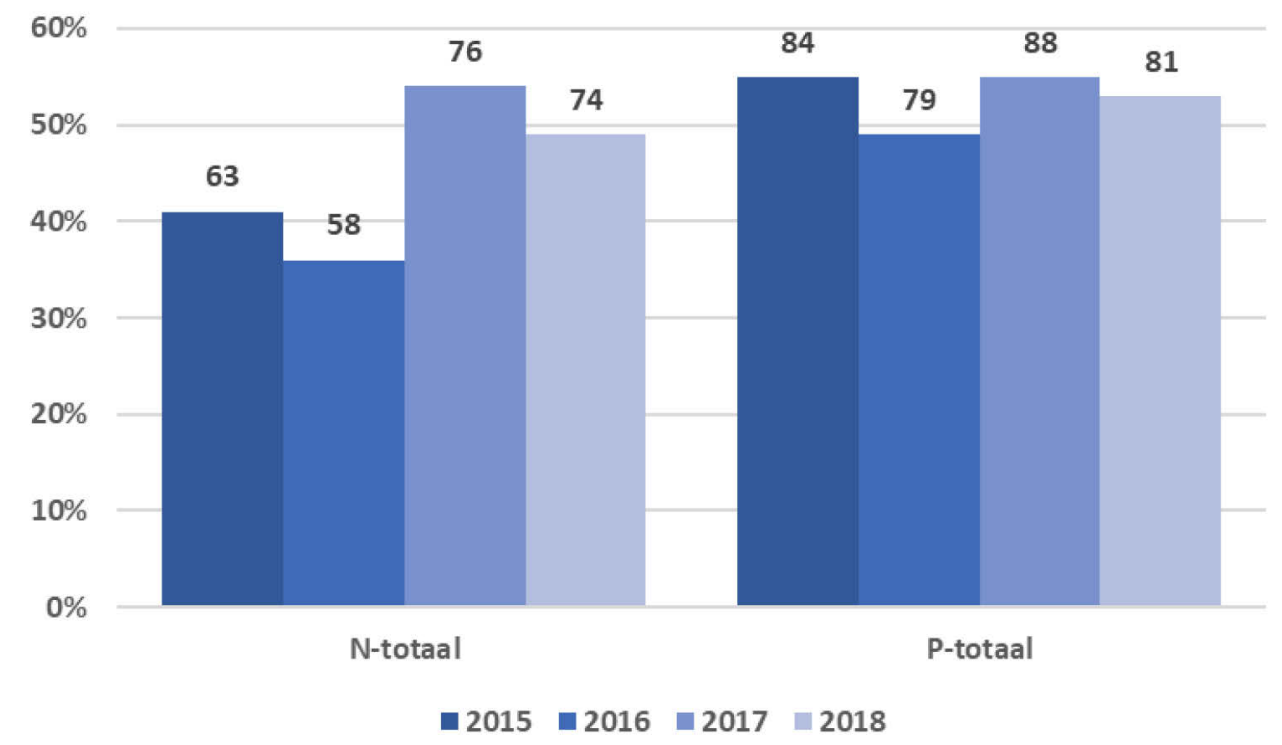

Figuur 47 Percentage meetlocaties in MNLSO dat voldoet aan de norm voor N-totaal (links) en P-totaal (rechts). Boven de staafdiagrammen staat het aantal locaties dat aan de norm voldoet (Buijs et al., 2020). 


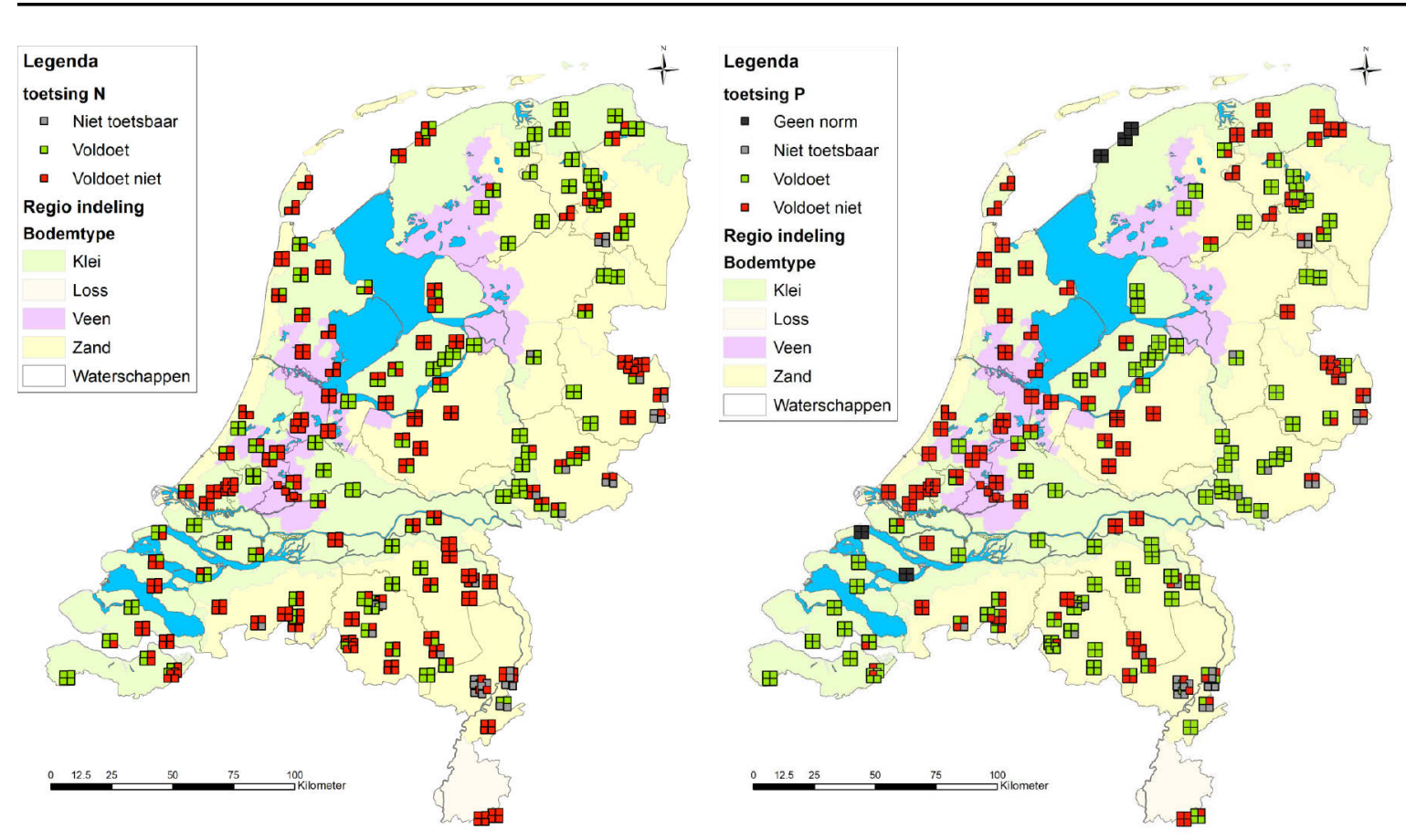

Figuur 48 Normoverschrijdingen 2015 t/m 2018 per MNLSO locatie voor N-totaal (linkerfiguur) en P-totaal (rechterfiguur), getoetst aan de waterschapsnorm. In beide figuren staat linksboven 2015, rechtsboven 2016, linksonder 2017 en rechtsonder 2018 (Buijs et al., 2020).

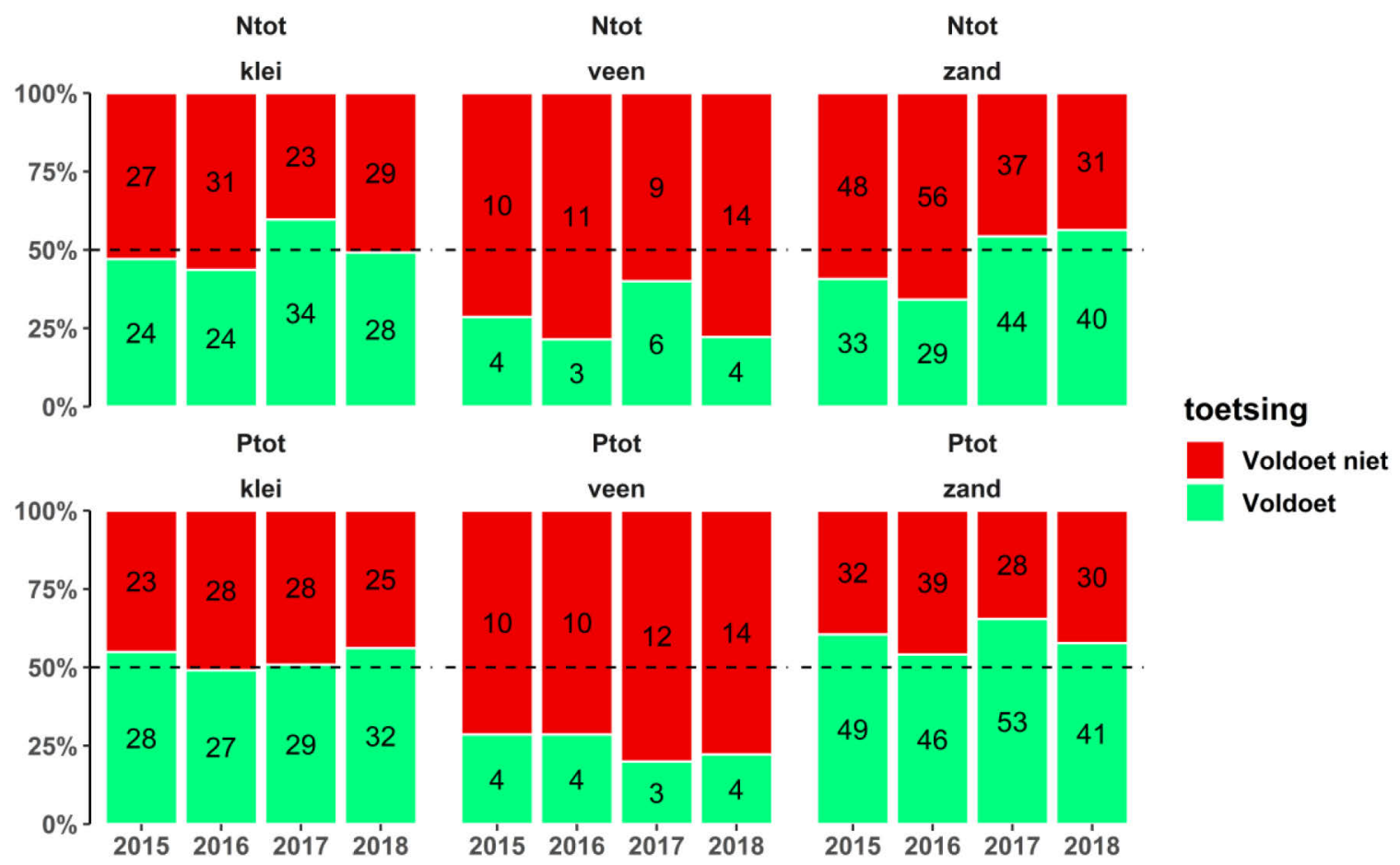

Figuur 49 Staafdiagrammen voor $N$-totaal (boven) en P-totaal (onder) per regio met op de $x$-as het jaar en op de $y$-as het percentage dat voldoet. Binnen het diagram staat het aantal corresponderende MNSLO-meetlocaties vermeld (Buijs et al., 2020). 


\subsection{Grondwaterbeschermingsgebieden}

Berekeningen van Claessens et al. (2017) geven aan dat de gemiddelde nitraatconcentratie in de bovenste meter van het grondwater binnen 40 grondwaterbeschermingsgebieden op termijn hoger is dan 40 mg nitraat per L. Sinds eind 2017 wordt in het kader van de 'Bestuursovereenkomst aanvullende aanpak nitraatuitspoeling uit agrarische bedrijfsvoering in specifieke grondwaterbeschermingsgebieden' door LTO Nederland, Vereniging van drinkwaterbedrijven in Nederland (Vewin), Interprovinciaal Overleg (IPO) en de ministeries van IenW en LNV samengewerkt, met als doel het terugdringen van de nitraatuitspoeling in de 34 kwetsbaarste grondwaterbeschermingsgebieden. Het doel is om uiterlijk in de periode van het Zevende Actieprogramma Nitraatrichtlijn (2022-2025) de nitraatdoelstelling te realiseren. De 34 beschouwde kwetsbare grondwaterbeschermingsgebieden bestaan voornamelijk uit zand- en/of lössgronden. Het totale areaal varieert van 121 tot 2752 ha per gebied en het percentage agrarisch gebruik van $7 \%$ tot $78 \%$. In 30 gebieden is de melkveehouderij (grasland + snijmaïs) de grootste agrarische grondgebruiker, in vier gebieden is dat akkerbouw of zijn het vollegrondsgroenten (Groenendijk et al., 2017).

Er is een verkennende deskstudy uitgevoerd van de aanpak voor de bestuursovereenkomst op basis van berekende stikstofoverschotten en nitraatconcentraties bij verschillend management (Van den Brink et al., 2020). Sterk verbeterd management leidt tot een lager stikstofoverschot op de bodem-balans en omvat in de melkveehouderij maatregelen als rekening houden met de stikstofnalevering uit vanggewassen, geen bemesting van maïs geteeld op gescheurd grasland en mestopslag van minstens tien maanden, zodat de bemesting kan worden geoptimaliseerd naar de omstandigheden. Bij akkerbouw wordt verondersteld dat door sterk verbeterd management de stikstofonttrekking door het gewas $10 \%$ hoger is dan een door Van den Brink et al. (2020) gedefinieerd 'normaal' management. Uit de berekeningen volgt dat een sterk verbeterd management op de agrarische bedrijven (met volledige deelname) op ongeveer 34\% van het landbouwareaal in de grondwaterbeschermingsgebieden leidt tot nitraatconcentraties in het uitspoelingswater lager dan $50 \mathrm{mg}$ nitraat per L.

Voor deze berekeningen waren nog geen meetgegevens beschikbaar van een begin 2020 gestarte monitoring en waren de modelaannames gebaseerd op een landelijk gemiddelde relatie tussen het stikstofoverschot op de bodembalans en de nitraatconcentratie in de bovenste meter van het grondwater, gedifferentieerd naar gewas, grondsoort en grondwatertrap (Fraters en Van Leeuwen, 2018). In het gebruikte kaartmateriaal worden de uitspoelingsgevoelige omstandigheden van de meeste grond-waterbeschermingsgebieden niet geheel onderkend. Daarnaast zijn er ook andere onzekerheden in de berekeningen, zoals het verwachte effect van maatregelen op het stikstofoverschot op de bodem-balans.

Onder andere op basis van deze deskstudy verwachten de betrokken provincies dat in 11 van de 34 gebieden ${ }^{19}$ bij het huidige deelnamepercentage en maatregelenpakket de doelstellingen van de bestuursovereenkomst naar verwachting worden gerealiseerd in 2025 (LBO, 2020). In 12 van de 34 gebieden ${ }^{20}$ zijn aanvullende maatregelen bij de agrariërs en/of een verhoogde deelname nodig. Het is de verwachting van de betrokken provincies dat onder voorwaarde van deze aanvullende maatregelen en/of een verhoogde deelname de doelstellingen in die gebieden worden gerealiseerd. In 11 van de 34 gebieden $^{21}$ zijn voor het behalen van de doelstellingen andersoortige maatregelen nodig om de doelstellingen in die gebieden te realiseren.

\footnotetext{
${ }^{19}$ Gasselte in Drenthe, Haarlo en Olden Eibergen in Gelderland, Bergen op Zoom, Gilze, Gilzerbaan, Helvoirt, Nuland en Waalwijk in Noord-Brabant en Archemerberg en Holten in Overijssel.

${ }^{20}$ Havelterberg in Drenthe, Dinxperlo en 't Klooster in Gelderland, De Dommel, De Tombe, Heer-Vroendaal, IJzeren Kuilen, Roodborn/Craubeek en Waterval in Limburg, Roosendaal in Noord-Brabant en Herikerberg en Wierden in Overijssel.

${ }^{21}$ Leggeloo en Noordbargeres in Drenthe, Beegden, Bergen, Breehei, Grubbenvorst, Heel en Mookerheide in Limburg, Vessem in Noord-Brabant en Hogehexel en Manderveen in Overijssel.
} 


\subsection{Biologische kwaliteit}

Fraters et al. (2020) beschrijven de eutrofiëringstoestand van oppervlaktewater conform de KRWsystematiek. Er worden daarbij zowel de nutriëntenstatus als biologische parameters beschouwd, zoals fytoplankton. De eutrofiëringstoestand van een waterlichaam wordt daarbij bepaald op basis van een driejarig gemiddelde van de parameters. Uit de analyse volgt dat $59 \%$ van de zoete KRWwaterlichamen in de periode 2016-2018 beoordeeld werd als eutroof (Tabel 13). Dit is een verbetering ten opzichte van de periode van drie jaar daarvoor. Bij de regionale wateren nam het aantal waterlichamen met een goede status (niet-eutroof) toe van 23 naar $30 \%$.

Tabel 13 Eutrofiëringskarakteristiek van de zoete wateren in de periode 2012-2014 en 2016-2018 (\% waterlichamen) (Fraters et al., 2020).

\begin{tabular}{|c|c|c|c|c|c|c|}
\hline & \multicolumn{3}{|c|}{ KRW-waterlichamen (2012-2014) } & \multicolumn{3}{|c|}{ KRW-waterlichamen (2016-2018) } \\
\hline & $\begin{array}{c}\text { Rijks- } \\
\text { wateren }\end{array}$ & $\begin{array}{r}\text { Regionale } \\
\text { wateren }\end{array}$ & Totaal & $\begin{array}{r}\text { Rijks- } \\
\text { wateren }\end{array}$ & $\begin{array}{l}\text { Regionale } \\
\text { wateren }\end{array}$ & Totaal \\
\hline Niet-eutroof & $57 \%$ & $23 \%$ & $25 \%$ & $60 \%$ & $30 \%$ & $32 \%$ \\
\hline Potentieel-eutroof & $23 \%$ & $10 \%$ & $10 \%$ & $20 \%$ & $9 \%$ & $10 \%$ \\
\hline Eutroof & $20 \%$ & $67 \%$ & $64 \%$ & $20 \%$ & $61 \%$ & $59 \%$ \\
\hline Aantal & 35 & 657 & 692 & 35 & 659 & 694 \\
\hline
\end{tabular}

De concentratie chlorofyl-a is een parameter voor eutrofiëring van wateren en rivieren. Normen voor chlorofyl-a zijn voor elk type waterlichaam apart afgeleid. Bij de landbouwspecifieke wateren zijn de laatste tien jaar relatief grote schommelingen in chlorofyl-concentraties te zien en is er in deze periode geen duidelijke trend (Figuur 50).

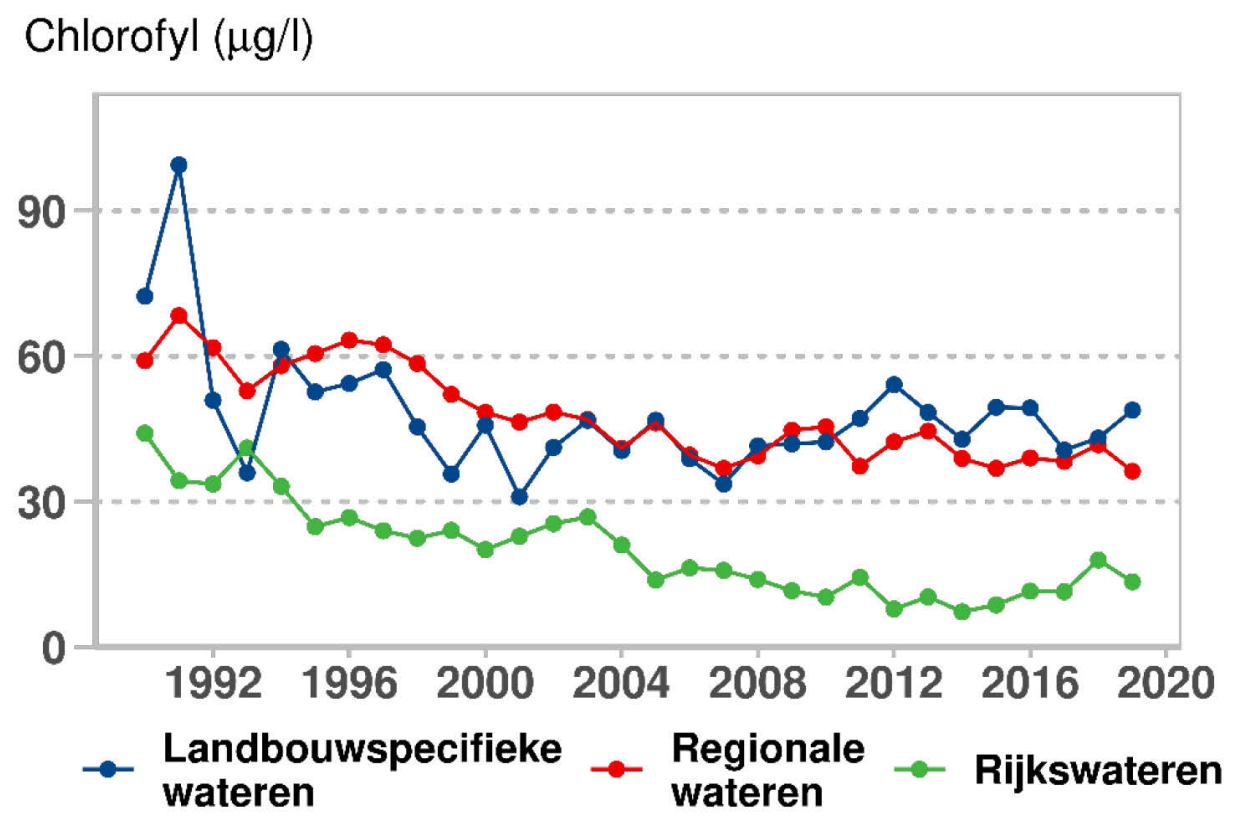

Figuur 50 Chlorofyl-a (zomergemiddelde concentratie in $\mu \mathrm{g} / \mathrm{l}$ ) in zoete oppervlaktewateren in de periode 1990-2019 (Fraters et al., 2020). 


\subsection{Samenvatting}

De nitraatconcentratie in het water dat uitspoelt uit de wortelzone op landbouwbedrijven in de zand-, veen-, löss- en kleiregio's laat langjarig een dalende trend zien, waarbij de sterkste daling in de jaren negentig van de vorige eeuw is opgetreden. $\mathrm{Er}$ is in 2018-2019 duidelijk sprake van een verandering ten opzichte van de stabiele of (licht) dalende nitraatconcentratie in de laatste tien jaar. In 2019 lag de gemiddelde nitraatconcentratie in de zand- en lössregio's boven de $50 \mathrm{mg}$ nitraat per $L$ en in de kleiregio iets onder de $50 \mathrm{mg}$ nitraat per L. De concentratie is in de zuidelijke zandregio is hoger dan in de zandregio's midden en noord. RIVM geeft aan dat de nitraatconcentratie in het grondwater in de winter 2019/2020 verder is gestegen. De langjarige trend tot 2018 laat gemiddeld duidelijk hogere nitraatconcentraties zien op akkerbouwbedrijven dan op melkveebedrijven op zandgrond. De concentraties op akkerbouwbedrijven in de zandregio zijn in 2016, 2017 en 2018 iets lager dan in de periode 2005-2015.

De gemiddelde nitraatconcentraties in het slootwater op LMM-bedrijven en derogatiebedrijven laat een sterke stijging zien in de winter 2018/2019 ten opzichte van eerdere jaren. In de zandregio is de nitraatconcentratie in het slootwater tot boven de $50 \mathrm{mg}$ nitraat per $\mathrm{L}$ gestegen. Het RIVM geeft aan dat de nitraatconcentraties in het drainwater in de winter 2019-2020 afnamen ten opzichte van 20182019, maar dat de concentratie nog niet op het niveau van 2017-2018 is.

Voor de concentratie $\mathrm{N}$-totaal in oppervlaktewater laat ruim $87 \%$ van de MNLSO-locaties een significantie neerwaartse trend zien en voor P-totaal is dit $53 \%$ voor de gehele periode vanaf begin jaren negentig van de vorige eeuw. Het percentage locaties in het MNLSO-meetnet dat aan waterschaps-normen voldoet, varieert voor stikstof tussen $36 \%$ in 2016 en $49 \%$ in 2018 en voor fosfor tussen 49\% (2016) en 55\% (2015 en 2017). Bij de fosforconcentratie zijn grote fluctuaties in de tijd zichtbaar in recente jaren. In kleigebieden is het percentage meetlocaties dat aan de norm $\mathrm{N}$-totaal voldoet hoger dan in de andere grondsoortregio's, behalve in 2018. Het percentage meetlocaties dat voldoet aan de norm P-totaal is het hoogst in het zandgebied. Op veengrond is het percentage meetlocaties dat voldoet aan de norm lager dan op andere grondsoorten, zowel voor $\mathrm{N}$-totaal als P-totaal.

Van de zoete KRW-waterlichamen werd 59\% beoordeeld als eutroof in de periode 2016-2018. Dit is een verbetering ten opzichte van de periode van drie jaar daarvoor. Bij de regionale wateren nam het aantal waterlichamen met een goede status (niet-eutroof) toe van $23 \%$ naar $30 \%$.

Uit de berekeningen van de nitraatuitspoeling in 34 kwetsbare grondwaterbeschermingsgebieden volgt dat een sterk verbeterd management op alle agrarische bedrijven op ongeveer $34 \%$ van het landbouwareaal leidt tot nitraatconcentraties in het uitspoelingswater lager dan $50 \mathrm{mg}$ nitraat per L. Er zullen dus ook andere maatregelen moeten worden verkend om de nitraatuitspoeling te verlagen in de kwetsbare gebieden. 


\section{Synthese}

\subsection{Trends in waterkwaliteit}

De nitraatconcentratie in het water dat uitspoelt uit de wortelzone op landbouwbedrijven in de zand-, veen-, löss- en kleiregio's laat langjarig een dalende trend zien, waarbij de sterkste daling in de jaren negentig van de vorige eeuw is opgetreden (Figuur 34). Als de zandregio wordt opgesplitst, is duidelijk dat in de zuidelijke zandregio de nitraatconcentratie gemiddeld rond de $75 \mathrm{mg}$ nitraat per $\mathrm{L}$ schommelt, terwijl die in de twee andere zandregio's in 2017 gemiddeld gelijk of lager dan 50 mg nitraat per L was (Figuur 36). Op melkveebedrijven werd in 2017 op alle grondregio's voldaan aan de nitraatnorm van 50 mg nitraat per L (Figuur 35; Figuur 37). De nitraatconcentratie op akkerbouwbedrijven in de zandregio laat een dalende trend zien, maar gemiddeld is de nitraatnorm nog niet gerealiseerd (Figuur 37). In 2018 en 2019 zijn de nitraatconcentraties door droogte sterk gestegen, vaak boven de nitraatnorm. Ook 2020 werd gekend door een droge periode (in het voorjaar). Als klimaatverandering ertoe leidt dat er vaker droge en natte perioden voorkomen, zullen er maatregelen genomen moeten worden in het kader van het mestbeleid om negatieve effecten op de waterkwaliteit te voorkomen (paragraaf 9.2).

De wintergemiddelde nitraatconcentratie in zoete wateren laat een dalende trend zien (Figuur 44). In de figuur wordt het wintergemiddelde voor een halfjaar getoond. In 2018-2019 was het uitspoelingsseizoen erg kort. In de periode september tot en met november 2018 waren de concentraties in het MNLSO dus nog erg laag (Buijs, 2020). Op maandbasis is in MNLSO echter hetzelfde effect van de droogte in 2018 te zien als in LMM; vanaf december 2018 (als de uitspoeling op gang komt) zijn de concentraties in het MNLSO ook hoog (Buijs, 2020). De zomergemiddelde stikstofconcentratie in zoete wateren laat een langjarig dalende trend zien (Figuur 45). Er is (nog) geen effect te zien van het droge jaar 2018. Het MNLSO is opgezet voor toestandsbepaling en trendbepaling in meetreeksen van minimaal tien jaar en niet specifiek voor het detecteren van effecten van een droog jaar op zomerconcentraties.

De gemiddelde fosforconcentraties fluctueren sterk in de tijd, maar langjarig is er sprake van een dalende trend in de meeste stroomgebieden (Figuur 45). De fosforconcentraties in de stroomgebieden van de Maas en Schelde laten daarentegen een opwaartse trend zien vanaf 2004. Welke factoren deze opwaartse trend veroorzaken, is onduidelijk. De neerwaartse trends in de meeste stroomgebieden suggereren dat maatregelen in de landbouw bijdragen aan de verbetering van de waterkwaliteit in landbouwgebieden. De metingen geven geen informatie over de oorzaken van de trends. Zowel aangescherpte gebruiksnormen als een verbeterde benutting van meststoffen kunnen hebben bijgedragen aan de verbeterde waterkwaliteit. De nutriëntenconcentraties van de normoverschrijdende locaties dalen echter te langzaam voor het behalen van de KRW-doelstellingen in 2027. Voor het behalen van de doelstellingen is in veel gebieden nog een extra inspanning nodig (Buijs et al., 2020).

In verkennende modelberekeningen (Van den Roovaart et al., 2020; Schipper et al., 2020; in prep.) is onderzocht of het voldoen aan de nitraatnorm in alle deelgebieden van het Maasstroomgebied zou leiden tot verlaging van stikstofconcentraties van het oppervlaktewater. Beide studies geven aan dat dit in beperkte mate het geval is en dat het voldoen aan de nitraatnorm in een aantal gebieden onvoldoende is om ook aan KRW-doelen te voldoen. De vraag welke nitraatconcentraties in het grondwater toelaatbaar zouden zijn voor het volledig bereiken van de KRW-doelen is nog niet beantwoord. Dergelijke niveaus zijn regiospecifiek. 


\subsection{Effecten van het weer op de waterkwaliteit}

De nitraatconcentraties in grond- en slootwater op landbouwbedrijven zijn sterk gestegen na de droge zomer van 2018 en de nitraatconcentraties in het grondwater zijn in de winter 2019/2020 verder gestegen. Mogelijk had een deel van het in de winter 2018/2019 uitgespoelde nitraat het grondwater nog niet bereikt en is in de winter 2019/2020 verder uitgespoeld. De nitraatconcentratie in het drainwater in LMM is wel gedaald in 2019/2020; de nitraatconcentratie in het drainwater reageert sneller op veranderingen in nitraatuitspoeling na het groeiseizoen dan het zich in diepere bodemlagen bevindende grondwater.

Zoals in Hoofdstuk 3 is aangegeven, kan droogte (weinig neerslag en hoge temperatuur) via verschillende mechanismen in de bodem een effect hebben op de kwaliteit van grondwater en oppervlaktewater. Een groot aantal factoren speelt hierbij een rol, namelijk effecten op het stikstofen/of fosfaat-overschot, verdunnings-/indikkingseffecten door de hoeveelheid uitspoelend water, biologische processen in de bodem en sloot- en transportroutes van stikstof en fosfaat in de bodem naar het grond- en oppervlaktewater. Al deze factoren kunnen een rol gespeeld hebben bij de toename van de nitraatconcentraties in grond- en slootwater na het droge jaar.

De stijging van de nitraatconcentratie is groot ten opzichte van de trend in de laatste tien jaar (Figuur 34; Figuur 35). De effecten van maatregelen op nitraatconcentraties zijn niet goed te evalueren binnen de fluctuatie die wordt veroorzaakt door schommelingen in het weer. De nitraatconcentraties gestandaardiseerd voor netto neerslag- en steekproefeffecten zijn in 2019 veel minder sterk toegenomen dan de gemeten nitraatconcentraties voor zand- en kleigronden (Figuur 51). De vraag die hierbij gesteld kan worden, is of deze statistische standaardisatie in staat is om alle genoemde effecten van droogte in rekening te brengen, omdat deze methode corrigeert voor weer, maar niet voor veranderd landbouwkundig handelen, veranderde biologische bodemprocessen en verminderde gewasopname tijdens droogte. Het gaat bij het gemeten effect niet alleen om het weer zelf, maar ook om hoe landbouw daarop reageert. Verder is het de vraag of de Europese Commissie gestandaardiseerde nitraatconcentraties accepteert bij de evaluatie van de nitraatactieprogramma's.

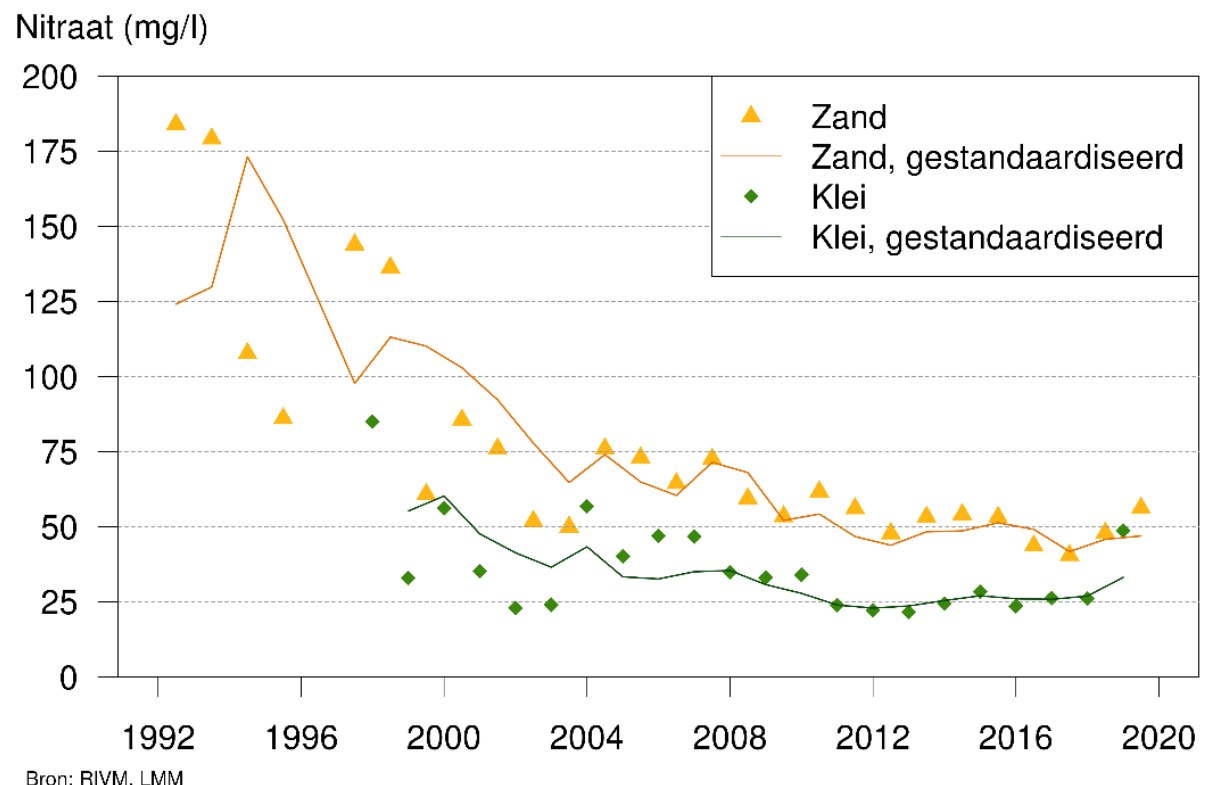

Figuur $51 \quad$ Nitraatconcentraties in het water dat uitspoelt uit de wortelzone op landbouwbedrijven in de zand- en kleiregio in de periode 1992-2019. Jaargemiddelde van areaal-gewogen gemeten en gestandaardiseerde concentraties (Fraters et al., 2020).

Er moet in de toekomst rekening worden gehouden met grilliger weer, met een toenemende kans op droogte en perioden met zware neerslag. De CDM (2020g) geeft aan dat bij aanhoudende droogte aanvullende maatregelen nodig zijn om de waterkwaliteitsdoelstelling te kunnen realiseren. Daarbij 
dient voor de nitraatdoelstelling ook rekening gehouden te worden met na-ijling van

nitraatuitspoeling. Het mestbeleid moet rekening houden met fluctuaties in weer, zodat ook in droge en natte jaren wordt voldaan aan de doelstellingen. Een toename van het voorkomen van droogte en perioden met zware neerslag door klimaatverandering maakt het meer weersbestendig maken van het mestbeleid urgenter.

De CDM (2020g) stelt dat er een groot aantal maatregelen mogelijk is om de effecten te beperken van aanhoudende droogte op nitraatuitspoeling naar het grondwater en stikstof- en fosforuitspoeling en -afspoeling naar het oppervlaktewater:

- Aanpassing van de bemesting op door droogte veranderde gewasopbrengsten;

- Vermindering van de droogte door efficiëntere beregening (druppelirrigatie) en hydrologische maatregelen (waterberging, grondwaterstandsverhoging);

- Uitspoeling-beperkende maatregelen (uitbreiding areaal vanggewassen, bufferstroken, barrières die afspoeling beperken en aanpassing van het tijdstip van graslandvernieuwing).

De CDM beveelt aan om de term 'aanhoudende droogte' voor verschillende situaties van klimaatverandering te definiëren en operationeel te maken voor het nemen van adequate maatregelen. Ook wordt aanbevolen om verder te onderzoeken welke pakketten van maatregelen het kosteneffectiefst zijn voor diverse situaties en regio's.

\subsection{Effecten van maatregelen uit het mestbeleid op landbouw en waterkwaliteit}

\subsubsection{Maatregelen Vijfde Actieprogramma Nitraatrichtlijn}

In het Vijfde Actieprogramma Nitraatrichtlijn zijn verschillende maatregelen genomen waarvan verwacht mag worden dat ze leiden tot minder uitspoeling van stikstof en fosfaat naar grond- en oppervlaktewater (paragraaf 2.2). Dit geldt met name voor de verlaging van de stikstofgebruiksnormen voor uitspoelingsgevoelige gewassen op zandgronden in het zuidelijke zand- en lössgebied met $20 \%$ in 2015 en verlaging van de derogatie voor bemesting met graasdierenmest in de zandregio's zuid en midden en de lössregio van 250 naar $230 \mathrm{~kg} \mathrm{~N}$ per ha in 2014 . Tevens werd vanaf 2014 als eis gesteld dat voor een bedrijf met derogatie het areaal minimaal uit $80 \%$ grasland moet bestaan (dit was $70 \%$ ), voor alle grondsoortregio's in Nederland. Door deze eis werd een uitspoelings-gevoelig gewas (maïs) vervangen door een minder uitspoelingsgevoelig gewas (grasland). De verlaging van fosfaatgebruiksnormen in 2014 en 2015 kan op langere termijn resulteren in minder fosfaatuitspoeling. De verhoging van de stikstofgebruiksnorm voor grasland op kleigrond en de invoering van een opbrengstafhankelijke stikstofgebruiksnorm voor graan op kleigrond zijn daarentegen maatregelen die tot meer stikstof uit- en afspoeling zouden kunnen leiden.

De maatregelen uit het Vijfde Actieprogramma zijn beoordeeld in een beknopte milieueffectrapportage (MER) op planniveau (Schoumans et al., 2013). In deze studie werd op basis van modelberekeningen geconcludeerd dat de inzet van het Vijfde Actieprogramma Nitraatrichtlijn zou leiden tot het gemiddeld realiseren van de $50 \mathrm{mg}$ nitraat per $\mathrm{L}$ streefwaarde voor nitraat in de bovenste meter van het grondwater in de zandgebieden. De maatregelen uit het Vijfde Actieprogramma lijken tot een vermindering van de nitraatuitspoeling op akkerbouwbedrijven op zandgrond te hebben geleid (Figuur 37), maar de onzekerheid is groot gezien de grote effecten van weer. In de MER-rapportage was een grotere daling in nitraatconcentratie voorzien. Mogelijke oorzaken voor het verschil in de gemeten (LMM) en berekende (MER) nitraatconcentratie zijn:

- Mogelijk ijlen de effecten van de maatregelen uit het vijfde Actieprogramma nog na, maar zijn niet zichtbaar door het grote effect van de droogte in 2018 op de waterkwaliteit in 2019. Het effect zou dan in de toekomst zichtbaar kunnen worden.

- Onzekerheden in het WOG-WOD-model dat in de MER-rapportage werd gebruikt. In een advies van de CDM (CDM, 2020h) werd geconstateerd dat er verschillende onderdelen van het WOG-WODmodel zouden moeten worden geactualiseerd en herzien. Het gaat hierbij onder andere over actualisering van de grondwatertrapverdeling in de zandgebieden, actualisering van stikstof-en 
fosfor-gehalten van gewassen, gewasresponscurven en uitspoelfracties en het beter rekening houden met korte- en langetermijneffecten van organische stikstof. Het is niet duidelijk wat het effect is op de berekende nitraatuitspoeling als al deze aanpassingen worden doorgevoerd.

- Het meetnet van het LMM is niet uitgebreid genoeg om effecten voor specifieke gebieden of teelten nauwkeurig in beeld te brengen.

- Er vindt in de praktijk waarschijnlijk overbemesting plaats (paragraaf 5.3.3), waardoor de uitgangspunten van de berekeningen in de MER-rapportage (bemesting volgens gebruiksnormen) en de bemesting in de praktijk niet overeenkomen.

- Het weer was anders dan het gemiddelde weer dat gebruikt is voor de WOG-WOD-berekeningen. De fluctuaties in nitraatconcentraties door veranderingen in het weer zijn relatief groot in vergelijking tot de verwachte effecten van maatregelen.

Verder werd in de MER-rapportage aangegeven dat belasting van het oppervlaktewater met stikstof en fosfor zeer beperkt zou dalen door de maatregelen uit het Vijfde Actieprogramma. Dit komt overeen met gemeten trends van de stikstof- en fosforconcentraties in landbouwspecifiek oppervlaktewater (Figuur 46). De stikstofbemesting op akkerbouwbedrijven op zand- en lössgrond is de laatste jaren gedaald (Figuur 21), terwijl de opbrengsten sterk variëren (Figuur 9). Opmerkelijk is dat de berekende stikstofoverschotten van akkerbouwbedrijven op zand- en lössgrond niet duidelijk zijn afgenomen vanaf 2014, ondanks de lagere stikstofbemesting (Figuur 26). Mogelijk dat onzekerheden in de berekeningen van het stikstofoverschot hierbij een rol spelen.

\subsubsection{Maatregelen Zesde Actieprogramma Nitraatrichtlijn}

\subsubsection{Algemeen}

De resultaten van de monitoring van de waterkwaliteit loopt tot in 2019 (paragraaf 8.2). Dit betekent dat de effecten van de meeste maatregelen uit het Zesde Actieprogramma Nitraatrichtlijn nog niet zichtbaar (kunnen) zijn, omdat ze in 2020 en 2021 zijn/worden geïmplementeerd (paragraaf 2.3). Van de maatregelen die 1 januari 2019 zijn ingegaan, is een deel gericht op verruimingen in landbouwkundig handelen, maar niet op het verbeteren van de waterkwaliteit. Het betreft de maatregelen verhoging van de stikstofgebruiksnorm voor de graszaadteelt van veldbeemd op kleigrond, toepassing van de groenbemestergebruiksnorm voor graszaadstoppel, verruiming van de uitrijdperiode van vaste dierlijke mest op grasland op klei- en veengrond en verschuiving van de uitrijdperiode van drijfmest. Hieronder wordt nader ingegaan op de maatregelen uit het Zesde Actieprogramma Nitraatrichtlijn die in 2019 zijn geïmplementeerd, namelijk maatregelen in het kader van het vernietigen van grasland en een vanggewas na snijmaïs.

\subsubsection{Vernietigen van grasland}

Het tijdstip van vernietigen van de graszode op zand- en lössgrond gevolgd door herinzaai met gras is in 2019 verruimd van de periode 1 februari-1 juni tot de periode 1 februari-1 september. Bij het vernietigen van grasland na 31 mei moet de gebruiksnorm met 50 kg N per ha worden gekort.

Het later vernietigen van grasland in het seizoen leidt tot een hoger risico op nitraatuitspoeling (CDM, 2017). De beperking van de gebruiksnorm met $50 \mathrm{~kg} \mathrm{~N}$ per ha leidt tot een lager risico op uitspoeling, maar het is onzeker of dit voldoende is om de hoge stikstofmineralisatie na het scheuren van grasland te compenseren. De stikstofgebruiksnormen voor maïs en consumptie- en fabrieksaardappelen die op zand- en lössgronden worden geteeld na het scheuren van grasland, worden in 2021 verlaagd met $65 \mathrm{~kg} \mathrm{~N}$ per ha. In welke mate de aanpassing van regels van vernietigen van grasland netto leiden tot een verlaging van nitraatconcentraties in het grondwater en een vermindering van de belasting van oppervlaktewater is nog niet bekend. In 2019 is veldonderzoek gestart waarin het effect van het vernietigen van grasland in voor- en najaar, met implementatie van maatregelen, wordt onderzocht. Voorlopige resultaten van het eerste jaar laten op zand- en lössgrond zien dat het vernietigen en herinzaai in augustus met een korting van de gebruiksnorm met $50 \mathrm{~kg} \mathrm{~N}$ per ha leidt tot een hogere nitraatuitspoeling dan vernietigen en herinzaai in het voorjaar (Van Schooten, persoonlijke mededeling). Het vernietigen en herinzaai in augustus met een korting van de gebruiksnorm met $50 \mathrm{~kg} \mathrm{~N}$ per ha leidde in dit onderzoek tot een vergelijkbare nitraatuitspoeling als scheuren in het voorjaar gevolgd door maïsteelt op zandgrond. Op lössgrond was de uitspoeling uit grasland dat vernietigd was in augustus (met korting van gebruiksnorm van $50 \mathrm{~kg} \mathrm{~N}$ per ha) duidelijk hoger dan die 
uit grasland vernietigd in het voorjaar gevolgd door maïs. Het onderzoek wordt nog twee jaar voortgezet, zodat eind 2021 beter onderbouwde conclusies kunnen worden getrokken over de effecten van maatregelen bij het vernietigen van grasland uit het Zesde Actieprogramma Nitraatrichtlijn op de waterkwaliteit.

\subsubsection{Teelt van een vanggewas}

De teelt van een effectief vanggewas na de teelt van maïs op zand en löss kan de nitraatuitspoeling snel en sterk reduceren. In veldonderzoek van Schröder et al. (1996; 2013) halveerde de nitraatconcentratie in het bovenste grondwater als er een vanggewas werd geteeld na snijmaïs. De stikstofopname van een vanggewas neemt in het najaar sterk af door de korte dagen en lagere temperaturen (Tabel 14). Een vanggewas is daarom vooral zinvol bij tijdige inzaai. In het Zesde Actieprogramma is opgenomen dat inzaai van een vanggewas op uiterlijk 1 oktober, aansluitend aan de oogst van de maïs, moet plaatsvinden. Om dit mogelijk te maken, moet snijmaïs in september worden geoogst. Signalen uit de landbouwpraktijk laten zien dat de teelt van vroege maïsrassen in opkomst is. Een tweede maatregel is de onderzaai van gras of een ander geschikt vanggewas in het perceel waarop de teelt van snijmaïs plaatsheeft. Veel boeren met snijmaïs hebben in 2019 gekozen voor onderzaai. Door droogte in juni/juli 2019 is onderzaai vaak volledig mislukt door droogte. Voor vanggewassen geldt een resultaatverplichting; als onderzaai is mislukt, moet er opnieuw een vanggewas worden ingezaaid. Een andere mogelijkheid is de inzaai van enkele specifieke gewassen met een hoge stikstofopname als hoofdteelt in de maand oktober na de teelt van snijmaïs, zoals wintertarwe. Het aantal maïstelers dat kiest voor inzaaien van een vanggewas na de teelt van maïs neemt toe; onderzaai wordt daardoor minder populair. Volgens een enquête waarover in Nieuwe Oogst werd bericht, ${ }^{22}$ koos in 2019 ruim 33\% van de maïstelers voor onderzaai als maïs op kniehoogte staat, $7 \%$ voor gelijktijdig inzaaien met de maïs, 35\% voor nazaai en ruim $24 \%$ voor geen vanggewas. Ook in 2020 lijken de meeste boeren voor nazaai van een vanggewas te kiezen. ${ }^{23}$

Het telen van een vanggewas na snijmaïs is een effectieve maatregel om nitraatuitspoeling te verminderen. De aangescherpte regelgeving in 2019 heeft geleid tot veranderingen in de praktijk. Er wordt meer geëxperimenteerd met vroege gewassen en onderzaai en er is voorlichting vanuit onderzoek (bijvoorbeeld het handboek groenbemesters ${ }^{24}$ en de ontwikkeling van een praktijktool ${ }^{25}$ ), zaadhandel en landbouwvoorlichting. Verwacht wordt dat de effectiviteit van de teelt van een vanggewas om nitraatuitspoeling te verminderen, zal toenemen.

Tabel 14 Berekende gemiddelde N-opname ( $k g$ per ha) van een vanggewas (boven- en ondergronds) in relatie tot zaaitijdstip (berekend op basis van relatie tussen bovengrondse $N$-opname en temperatuursom tussen zaai en inwerken zoals afgeleid in Schröder et al (1996) voor een gemiddeld weerjaar, en de aanname dat de ondergrondse $\mathrm{N}$-opname $15 \%$ van de bovengrondse opname bedraagt). Berekeningen zijn gedaan voor Noord en Zuid-Nederland (Bron: CDM, 2017 b).

\begin{tabular}{|c|c|c|c|}
\hline Zaaitijdstip & Noord & Zuid & Gem. Noord en Zuid \\
\hline 10 aug & 108 & 116 & 112 \\
\hline 20 aug & 88 & 95 & 91 \\
\hline 10 sept & 51 & 57 & 54 \\
\hline 20 sept & 36 & 42 & 39 \\
\hline 10 okt & 11 & 16 & 13 \\
\hline 20 okt & 2 & 7 & 4 \\
\hline 1 nov & 0 & 0 & 0 \\
\hline
\end{tabular}

\footnotetext{
22 https://www.nieuweoogst.nl/nieuws/2020/02/12/meer-maistelers-kiezen-voor-nazaai

${ }^{23}$ https://www.nieuweoogst.nl/nieuws/2020/09/28/boeren-stoeien-met-teelt-vanggewas

${ }^{24}$ https://www. handboekgroenbemesters. nl/nl/handboekgroenbemesters.htm

${ }^{25}$ http://www.grondigboerenmetmais.nl/2019/11/19/vanggewas-tool/
} 


\subsubsection{Overige maatregelen}

In 2021 wordt de eerste datum waarop het is toegestaan drijfmest toe te dienen aan maïs op zand- en lössgronden verschoven van 15 februari naar 15 maart. De equivalente maatregel 'rijenbemesting in maïs' zal hierdoor ook vervallen per 1 januari 2021. Het risico op nitraatuitspoeling naar het grondwater neemt in de periode februari-april sterk af, omdat het neerslagoverschot sterk afneemt in deze periode en de gewasopname hoger wordt bij stijgende temperaturen. Er wordt echter niet verwacht dat deze maatregel grote effecten op nitraatuitspoeling heeft, omdat de eerste gift van drijfmest op maïs vaak pas laat in het voorjaar toegediend wordt.

De stikstofgebruiksnorm voor consumptie- en fabrieksaardappelen en snijmaïs op zand- en lössgrond die het jaar na het vernietigen van grasland worden geteeld, wordt in 2021 met $65 \mathrm{~kg} \mathrm{~N}$ per ha gekort. Deze maatregel zal waarschijnlijk tot een vermindering van nitraatuitspoeling leiden.

In 2021 worden maatregelen geïmplementeerd om de afspoeling in ruggenteelten op kleigrond en lössgrond te voorkomen. Het gaat hierbij om drempels om afspoeling te voorkomen, walletjes van minimaal $5 \mathrm{~cm}$ hoog op maximaal $2 \mathrm{~m}$ afstand tussen de ruggen, of het aanleggen van een opvanggreppel of infiltratiesleuf die bij normale weersomstandigheden het afstromende water opvangen en niet afwateren op de watergang, of het toepassen van een onbeteelde en onbemeste zone van minimaal $3 \mathrm{~m}$ breed langs de watergang. De drempels mogen worden opengebroken bij veel neerslag, waarbij het risico ontstaat dat het perceel blank komt te staan. Het is niet bekend hoe effectief drempels zijn om de afspoeling van stikstof en fosfaat naar het oppervlaktewater te beperken. Uit de sector komen zowel positieve ${ }^{26}$ als negatieve ${ }^{27}$ geluiden over implementatie van deze maatregel.

In het Zesde Actieprogramma worden ook verschillende fosfaatmaatregelen genomen. De fosfaatgebruiksnormen zijn verlaagd en de indeling van de fosfaatklassen op landbouwgrond is in 2020 aangepast. Vanaf 2021 wordt een gecombineerde indicator van $\mathrm{P}-\mathrm{CaCl}_{2} / \mathrm{P}-\mathrm{AL}$ voor zowel grasals bouwland ingevoerd. Voor sommige boeren kan deze indicator tot grote veranderingen in gebruiksruimte leiden (met name voor bouwland op kleigrond), maar nationaal gezien wordt er geen grote verandering verwacht in gebruiksruimte door invoering van een gecombineerde indicator. De CDM (2019b) concludeert dat de effecten van de invoering van de gecombineerde indicator op het milieu naar verwachting gering zijn, omdat de veranderingen in fosfaatplaatsingsruimte klein zijn (zo'n $2 \%$ lager). De fosfaattoestand-afhankelijke fosfaatgebruiksnormen leiden ertoe dat in de toekomst de fosfaattoestand zal dalen als de fosfaattoestand nu hoog is, en zal toenemen als de fosfaattoestand nu relatief laag is. Dit is zowel landbouwkundig als milieukundig juist.

In het zesde Actieprogramma worden naast de bovengenoemde maatregelen ook andere maatregelen genoemd, zoals de aanleg van droge bufferstroken, de vermindering van erfemissies en de bestuursovereenkomst Nitraat in grondwaterbeschermingsgebieden. De eerste twee maatregelen dienen of nog geïmplementeerd te worden of zijn nog in uitvoering. Ook voor de bestuursovereenkomst is het nog te vroeg om over effecten te kunnen rapporteren.

\subsubsection{Verwachte effecten op waterkwaliteit}

De strengere eisen aan het zaaien van een vanggewas na snijmaïs zullen waarschijnlijk de komende jaren tot een verlaging van de nitraatuitspoeling leiden. Ook zal de korting van de stikstofgebruiksnorm bij teelt van maïs en aardappelen na het vernietigen van grasland tot minder nitraatuitspoeling leiden. In de beknopte milieueffectrapportage (MER) op planniveau van het Zesde Actieprogramma Nitraatrichtlijn werd geconcludeerd dat het pakket maatregelen een beperkt effect heeft op de landelijke gemiddelde nitraatconcentratie in het grondwater en onvoldoende om gebiedsgemiddeld in het zuidelijke zand- en lössgebied aan de nitraatnorm van $50 \mathrm{mg}$ nitraat per $L$ te voldoen (Groenendijk et al. (2017). Hierbij moet worden opgemerkt dat er in de MER van uit werd gegaan dat het verplicht stellen van rijenbemesting met mest bij maïs op zand- en lössgrond een effectieve maatregel zou zijn om nitraatuitspoeling te beperken. Inmiddels is duidelijk dat deze maatregel door een andere wijze van implementatie in de praktijk ten opzichte van het onderzoek veel minder effectief is in het reduceren van nitraatuitspoeling (Klootwijk en Van Schooten, 2020). De

\footnotetext{
${ }^{26}$ https://www.akkerwijzer.nl/artikel/245389-drempels-tussen-aardappelruggen-hebben-duidelijk-positief-effect/

${ }^{27}$ https://www.nieuweoogst.nl/nieuws/2020/05/19//to-maatregelen-afspoeling-ruggenteelt-schieten-doel-voorbij
} 
verplichting tot rijenbemesting is inmiddels teruggetrokken als maatregel. Het vervangen van de maatregel van verplichting tot de teelt van een vanggewas na aardappelen door een korting van de gebruiksnorm van aardappelen met $65 \mathrm{~kg} \mathrm{~N}$ per ha na het vernietigen van grasland heeft mogelijk een positief effect, omdat de stikstofopname van een vanggewas in oktober (na de oogst van aardappelen) beperkt is (Tabel 14). In de MER van Groenendijk et al. (2017) werd ook geconcludeerd dat er geringe effecten op de stikstof- en fosfaatbelasting van het oppervlaktewater worden verwacht bij de maatregelen uit het Zesde Actieprogramma.

\subsubsection{Deltaplan Agrarisch Waterbeheer}

Het Deltaplan Agrarisch Waterbeheer (DAW) is in 2013 als initiatief van LTO Nederland van start gegaan en heeft als ambitie een bijdrage te leveren aan de wateropgaven in agrarische gebieden en het realiseren van een economisch sterke en duurzame landbouw. Heel concreet zijn daarbij de volgende doelen geformuleerd:

- Het bereiken van een betere waterkwaliteit (oplossen van alle knelpunten in 2027);

- Zorgen voor voldoende water (optimale waterhuishouding en spaarzaam watergebruik);

- Koersen op hogere productie en efficiënt ruimtegebruik.

Vanuit het DAW-programma worden agrarisch ondernemers gestimuleerd en gefaciliteerd om met een water- en bodemgerichte bedrijfsvoering te werken aan duurzame oplossingen voor de wateropgaven. Daartoe is de afgelopen jaren samengewerkt met het agrarisch bedrijfsleven en waterbeheerders. Gezamenlijk wordt er ingezet op kennisverspreiding met betrekking tot de goede landbouwpraktijk conform het Zesde Actieprogramma Nitraatrichtlijn, een optimale nutriëntenbenutting, duurzaam bodembeheer, optimale invulling van gewasbescherming en het vergroten van het klimaatadaptieve vermogen van bodems en bedrijven. Ook coördineert het DAW de uitvoering van de bestuursovereenkomst Nitraatuitspoeling in 34 grondwaterbeschermingsgebieden.

In 2019 werd in 334 projecten aandacht geschonken aan nutriënten, waarvan in 171 aan kennisoverdracht, in 58 projecten aan sluiten van kringlopen (voornamelijk in de vorm van een plan door meerdere bedrijven in een gebied), 40 projecten waarin een integraal bedrijfsplan werd opgesteld ter bevordering van waterbewust boeren, 40 projecten gericht op het tegengaan van erfafspoeling en 31 projecten waar in precisiebemesting werd geïnvesteerd (LTO, 2019). In enkele projecten zijn metingen verricht naar effecten van maatregelen, bijvoorbeeld maatregelen om erfafspoeling tegen te gaan in het beheersgebied van waterschap Vallei en Veluwe en HRRS De Stichtse Rijnlanden. In andere projecten worden metingen verricht voor bewustwording en systeeminzicht, bijvoorbeeld in het project Waterwijs Boeren in het grondwaterbeschermingsgebied van waterwinning 't Klooster, en Boeren met Water 2.0 Noord-Holland. Gerichte monitoring door metingen om effecten van maatregelen vast te stellen, vindt buiten de bestuursovereenkomst Nitraat in grondwaterbeschermingsgebieden nauwelijks plaats.

\subsubsection{Derogatie}

Melkveebedrijven met een derogatie voldoen in recente jaren gemiddeld aan de nitraatnorm voor grondwater op elke grondsoort, behalve op lössgrond (Figuur 35). De CDM heeft een advies opgesteld over de milieueffecten van een derogatie (CDM, 2020b). In dit advies wordt geconcludeerd dat bij geen derogatie de nitraatuitspoeling waarschijnlijk zal toenemen, omdat grasland zal worden omgezet in maïsland voor de productie van meer eiwitarm voer. Het omzetten van grasland in maïsland kan leiden tot een stijging van de nitraatuitspoeling, met name op de zand- en lössgronden (Schröder et al., 2007). Grasland heeft een lang groeiseizoen en een relatief hoge stikstofopname-capaciteit (Schröder et al., 2009) en hoge denitrificatiecapaciteit (Munch en Velthof, 2007) in vergelijking tot snijmaïs. Hierdoor is de nitraatuitspoeling uit grasland lager dan uit maïsland (Figuur 38). Door het niet verlengen van een derogatie zullen er verschuivingen optreden in het gebruik van dierlijke mest en kunstmest op zowel grasland, maïsland en bouwland. Het netto-effect van deze verschuivingen in bemesting zal volgens de CDM relatief beperkt zijn. Als geen derogatie leidt tot een krimp van het aantal varkens en/of overig rundvee, dan zal het mestoverschot kleiner worden. Dit heeft geen direct effect op nitraatuitspoeling, omdat de gebruiksnormen op de huidige derogatie-bedrijven volledig worden benut met kunstmest en rundveemest (paragraaf 5.3.1.1). Er worden geen grote effecten 
verwacht van geen derogatie op de belasting van oppervlaktewater met stikstof en fosfaat. Verwacht wordt dat het verbod op het gebruik van fosfaatkunstmest wordt opgeheven als er geen mogelijkheid tot derogatie bestaat, zodat op melkveehouderijen de fosfaatgebruiksnorm wordt opgevuld door fosfaatkunstmest.

\subsection{Effecten van andere factoren op de waterkwaliteit}

Het areaal uitspoelingsgevoelige gewassen (aardappelen, groenten, (snij)maïs) is niet significant veranderd in Nederland tussen 2010 en 2018. Het areaal grasland (permanent en tijdelijk) is ook weinig veranderd in deze periode. Er zijn dus geen grote veranderingen in gewassoort opgetreden in de laatste tien jaar die tot veranderingen in waterkwaliteit hebben geleid. De opbrengsten van akkerbouwgewassen fluctueren de laatste jaren door effecten van droogte (Figuur 9), na een periode van meer dan tien jaar stijgende trend, behalve voor aardappelen (Velthof et al., 2017). Veranderingen in opbrengsten bij gelijkblijvende bemesting leiden tot veranderingen in stikstof- en fosfaatoverschotten en daarmee tot veranderingen in het risico op stikstof- en fosforuitspoeling.

Ammoniakemissiebeperkende maatregelen kunnen een effect hebben op de nitraatuitspoeling, omdat deze maatregelen de hoeveelheid stikstof die met mest wordt toegediend, beïnvloeden. Bij alle diercategorieën is het aantal emissiearme huisvestingssystemen toegenomen sinds 2010 . Als de ammoniakemissie uit stallen wordt beperkt, zal de hoeveelheid stikstof in de mest toenemen of zal stikstof in luchtwassers zijn opgevangen en als spuiwater beschikbaar zijn. Het spuiwater wordt als stikstofmeststof toegepast. Bij berekening van de forfaitaire stikstofproductie in het kader van de Meststoffenwet wordt de hoeveelheid berekende stikstof in de mest gecorrigeerd voor de gasvormige stikstofverliezen in stallen en mestopslagen. De forfaits van een groot deel van de diercategorieën zijn eind 2019 geactualiseerd (Bikker et al., 2019; Van Bruggen en Geertjes, 2019). Gezien de snelle ontwikkelingen in het ammoniakdossier is het van belang dat de mestproductieforfaits frequent (eens per drie jaar) worden geactualiseerd om te voorkomen dat de hoeveel stikstof in mest in de praktijk sterk afwijkt van die in de Meststoffenwet. In de laatste jaren zijn weinig veranderingen opgetreden in de mesttoedieningstechnieken die gebruikt worden. Bij de werkingscoëfficiënten die in het mestbeleid worden gehanteerd, wordt geen rekening gehouden met de mesttoedieningstechniek (dit in tegenstelling tot de bemestingsadviezen van CBGV en CBAV). Er kan overbemesting en daarmee een hoger risico op nitraatuitspoeling optreden indien de wettelijke werkingscoëfficiënt lager is dan de werkelijke werkingscoëfficiënt. De wettelijke werkingscoëfficiënten gaan uit van alleen eerstejaars werking, maar de meerjarige werking van mest is hoger. Schröder en Van Dijk (2019) concluderen dat de verhoging van de wettelijke werkingscoëfficiënt van dunne mest naar $70-80 \%$ en van vaste mest naar $55-75 \%$ beter overeenkomt met de werkelijkheid, ook bij bedrijven met beweiding. Als de werkingscoëfficiënten worden aangepast, moeten ook de stikstofgebruiksnormen worden aangepast (CDM, 2020h).

Het is niet duidelijk op welke schaal en waar overbemesting plaatsvindt. Wel is duidelijk dat overbemesting het bodemoverschot vergroot en daarmee mogelijk mede een oorzaak kan zijn van een verslechtering van de waterkwaliteit. De mate waarin vergt nader onderzoek.

In Hoofdstuk 7 is een overzicht gegeven van ontwikkelingen in de bodemkwaliteit. Bodemverdichting komt op grote schaal voor in Nederland en heeft waarschijnlijk een effect op de uitspoeling van stikstof en fosfaat naar grond- en oppervlaktewater. Het is echter niet bekend welke rol bodemverdichting speelt bij de belasting van grond- en oppervlaktewater met nutriënten en of hier de laatste tien jaar veranderingen in zijn optreden. De trend in het gehalte aan organische stof in landbouwgronden is stabiel tot licht stijgend en er is geen reden om aan te nemen dat het gehalte aan organische stof heeft geleid tot veranderingen in waterkwaliteit. De chemische bodemvruchtbaarheid is goed en zal gemiddeld genomen in Nederland niet leiden tot daling van gewasopbrengsten en daardoor tot meer stikstof- en fosforuitspoeling. De fosfaattoestand van veel landbouwpercelen is hoog. Dit kan tot fosforuitspoeling leiden. De toename van de fosforconcentratie in uitspoelend water op zandgronden is mogelijk een indicatie dat fosfor in toenemende mate uitspoelt (Figuur 39), maar dit is nog erg onzeker, omdat de stijging werd veroorzaakt door slechts enkele bedrijven. Er is geen 
aanleiding om te veronderstellen dat veranderingen in bodembiodiversiteit gedurende de laatste tien jaar hebben geleid tot veranderingen in waterkwaliteit.

In de landbouw wordt in toenemende mate gebruikgemaakt van mestbewerkingsproducten. Ros et al. (2019) concluderen dat mestbewerking het risico op stikstofafspoeling naar het oppervlaktewater kan verlagen, omdat er beter gestuurd kan worden op het vrijkomen van stikstof (de timing van bemesting), de plaatsing (in de rij, met zodenbemester etc.) en de hoogte van de werkzame stikstofgift. Experimenteel onderzoek laat zien dat het risico op nitraatuitspoeling bij gebruik van mineralenconcentraten vergelijkbaar is aan die van kunstmest (Middelkoop en Holshof, 2017; Schils et al., 2014; Schröder et al., 2013).

\section{$9.5 \quad$ Vooruitblik}

\subsubsection{Ontwikkeling van de waterkwaliteit in de toekomst}

De nitraatconcentratie in grond-, drainage- en slootwater wordt sterk beïnvloed door het weer. In de laatste drie jaar is sprake van droge perioden in het groeiseizoen (Figuur 4). Mochten deze droge perioden (vaak gevolgd door een natte periode) door klimaatverandering in de toekomst vaker voorkomen, dan wordt het lastig om de effectiviteit van maatregelen op de waterkwaliteit te bepalen. De verwachte effecten van de maatregelen op waterkwaliteit zijn namelijk kleiner dan de door droogte veroorzaakte fluctuaties in waterkwaliteit in recente jaren. In de monitoring van waterkwaliteit is altijd al sprake geweest van jaar-tot-jaarverschillen. In de monitoringsopzet en dataverwerking en -interpretatie van de resultaten moet daar rekening mee worden gehouden. Bij LMM wordt daarvoor een weercorrectie uitgevoerd (Boumans en Fraters, 2017). In MNLSO worden trendanalysemethoden toegepast die niet worden beïnvloed door jaar-tot-jaarschommelingen. Voor beide meetnetten geldt dat het gevaarlijk is om conclusies te trekken op basis van verschillen tussen individuele meetjaren.

Het is niet te verwachten dat na-ijling van de maatregelen uit het Vijfde Actieprogramma en de maatregelen uit het Zesde Actieprogramma ertoe gaan leiden dat voldaan wordt aan de nitraatdoelstellingen. In de Nationale analyse waterkwaliteit wordt geconcludeerd dat als gevolg van de bestaande en voorgenomen maatregelen een gestage verbetering voor het doelbereik van de biologische KRW-normen wordt bereikt (Van Gaalen et al., 2020; Groenendijk et al., 2020). Onder het huidige beleid werd hierbij verstaan de vastgestelde KRW-maatregelen uit de stroomgebiedbeheerplannen 2016-2021, het Zesde Actieprogramma Nitraatrichtlijn en lopende maatregelen in het kader van het Deltaplan Agrarisch Waterbeheer (DAW). Volgens de modelberekeningen in de Nationale analyse waterkwaliteit zullen echter met de voorziene maatregelen niet alle doelen overal worden gehaald: het aandeel regionale wateren dat in 2027 voldoet, ligt per biologische norm tussen de 30 en $60 \%$; voor de zoete rijkswateren wordt het doelbereik op bijna $100 \%$ berekend. Verder komt uit de analyse naar voren dat ook voor nutriënten niet overal aan de KRW-normen zal worden voldaan. Om de doelen te kunnen halen, zijn voor een deel van de wateren, waaronder delen van het Maasstroomgebied, verdergaande structurele maatregelen nodig.

\subsubsection{Deltaplan Agrarisch Waterbeheer}

In de Nationale Analyse Waterkwaliteit zijn effecten van bovenwettelijke vrijwillige maatregelen, die door stimulering van DAW worden genomen, ingeschat met rekenmodellen (Van Gaalen et al., 2020). Hierbij zijn verschillende graden van deelname verondersteld. Onderscheid is gemaakt tussen DAWmaatregelen bij gelijkblijvend beleid en middelen, bij aanvullende maatregelen, inclusief maatregelen die serieuze investeringen of ingrepen vragen en bij een implementatie van de maatregelen op alle landbouwpercelen waar deze relevant zouden zijn. Maatregelen die worden genomen, zijn teeltwisseling, bufferstroken, verwijdering van nutriënten uit drainagewater, het optimaliseren van de toepassing van mest, het gebruik van minder uitspoelingsgevoelige meststoffen, ruggenteelt, rust- en vanggewassen, drainagesystemen en extensiveren/uitmijnen. Het pakket bevat geen waterhuishoudkundige maatregelen zoals drainage, peilbeheer of beregening. Met de in de Nationale Analyse Waterkwaliteit doorgerekende DAW-maatregelen bij gelijkblijvend beleid en middelen zou de nutriënten-belasting van regionale wateren door landbouwbemesting landelijk gemiddeld met enkele 
procenten afnemen. Bij aanvullende maatregelen (zoals peilgestuurde drainage en fosfaatuitmijning), inclusief maatregelen die serieuze investeringen of ingrepen vragen (zoals herinrichting van gebieden), zou de vermindering van de uit- en afspoeling van stikstof $10 \%$ bedragen en van fosfor $15 \%$. Als de maatregelen geïmplementeerd worden op alle landbouwpercelen waar een maatregel relevant is, zou de vermindering voor zowel stikstof als fosfor kunnen oplopen tot meer dan $30 \%$.

Gebiedsgemiddelde nitraatconcentraties in het grondwater zouden met de DAW-maatregelen bij gelijkblijvend beleid en middelen met 1-2 mg nitraat per $L$ verminderd worden ten opzichte van de huidige praktijk. Bij aanvullende maatregelen zou de vermindering $3 \mathrm{mg}$ nitraat per $\mathrm{L}$ bedragen en bij implementatie van de maatregelen op alle percelen waar dit relevant is, zou de vermindering 7-8 $\mathrm{mg}$ nitraat per $L$ bedragen. DAW-maatregelen zullen in het algemeen leiden tot enige verbetering van de waterkwaliteit. Voor een aantal gebieden kan een verhoogde inzet van deze maatregelen leiden tot het behalen van doelen van de Kaderrichtlijn Water, maar voor andere gebieden zijn aanvullende maatregelen nodig voor volledig doelbereik.

\subsubsection{Grondwaterbeschermingsgebieden}

Uit een verkennende deskstudy in het kader van de evaluatie van de aanpak voor de 'Bestuursovereenkomst aanvullende aanpak nitraatuitspoeling uit agrarische bedrijfsvoering in specifieke grondwater-beschermingsgebieden' volgt dat een sterk verbeterd management op de agrarische bedrijven (met volledige deelname) op ongeveer $34 \%$ van het landbouwareaal in de grondwaterbeschermingsgebieden leidt tot nitraatconcentraties in het bovenste grondwater lager dan $50 \mathrm{mg}$ nitraat per L. Voor de desk-study waren nog geen resultaten van metingen in de grondwaterbeschermingsgebieden beschikbaar. Van den Brink et al. (2020) geven aan dat naast maatregelen die leiden tot een lager bodemoverschot, ook andere maatregelen moeten worden verkend om de nitraatuitspoeling te verlagen.

Opgemerkt wordt dat implementatie van de maatregelen bij een sterk verbeterd management uit de studie van den Brink (2020) op korte termijn veel zal vragen van de boeren. Bij melkveebedrijven worden bij sterk verbeterd management technieken toegepast die ook op Proefbedrijf De Marke worden toegepast. Bij akkerbouw wordt verondersteld dat door sterk verbeterd management de stikstofonttrekking door het gewas 10\% hoger is dan een door Van den Brink et al. (2020) gedefinieerd normaal management. Er zijn grote fluctuaties in opbrengsten in de tijd en alleen bij suikerbieten en wintertarwe zijn de opbrengsten sinds 2010 gestegen (Figuur 9). Het realiseren van een gemiddeld $10 \%$ hogere stikstofopbrengst van akkerbouwgewassen binnen enkele jaren lijkt niet realistisch als de trend uit Figuur 9 worden doorgetrokken. Maatregelen als rekening houden met de stikstofnalevering uit vanggewassen en geen bemesting van maïs geteeld op gescheurd grasland zijn daarentegen wel snel implementeerbaar en effectief om nitraatuitspoeling te beperken.

De resultaten van de deskstudy van Van den Brink et al. (2020) en de onzekerheid of de gehanteerde uitgangspunten van de berekeningen ook in de praktijk daadwerkelijk gerealiseerd kunnen worden, geven aan dat het realiseren van de doelstellingen uit de bestuursovereenkomst zeer lastig zullen zijn.

In het besluit van Landelijk Bestuurlijk Overleg Nitraat in grondwaterbeschermingsgebieden ${ }^{28}$ stellen de provincies dat men verwacht dat in 11 van de 34 gebieden andersoortige maatregelen nodig zijn om de doelstellingen in die gebieden te realiseren. $\mathrm{Er}$ is niet aangegeven welke maatregelen dit zijn.

Aanpassingen van de gewassen in het bouwplan en extensivering zouden maatregelen kunnen zijn om in grondwaterbeschermingsgebieden te voldoen aan de nitraatnorm.

\subsubsection{Aanvullende maatregelen om uitspoeling van nutriënten te beperken}

Uit voorgaande blijkt dat er aanvullende maatregelen nodig zijn om te voldoen aan de waterkwaliteitsdoelstellingen. Er zijn in het kader van de onderhavige studie geen ex-ante-

\footnotetext{
${ }^{28}$ https://www.rijksoverheid.nl/binaries/rijksoverheid/documenten/kamerstukken/2020/07/17/besluit-van-het-lbo-inzakeafspraak-7c-van-de-bestuursovereenkomst/bijlage-besluit-van-het-lbo-inzake-afspraak-7c-van-debestuursovereenkomst.pdf
} 
modelberekeningen uitgevoerd naar maatregelen om aan de doelen te voldoen. Er kan een onderscheid worden gemaakt tussen het stimuleren van het nemen van maatregelen om uitspoeling te beperken of verplichte maatregelen in kader van Nitraatrichtlijnactieprogramma's. Stimuleren van maatregelen kan bijvoorbeeld door het toepassen van de BedrijfsWaterWijzer op melkveebedrijven ${ }^{29}$ of het nemen van maatregelen uit de zogenaamde BOOT-lijst (Bestuurlijk Overleg Open Teelten en veehouderij) in het kader van DAW (Verloop et al., 2018 ${ }^{30}$ ). In deze lijst staan maatregelen om waterkwaliteit en -kwantiteit en bodemkwaliteit te verbeteren. Een deel van de maatregelen kan gesubsidieerd worden vanuit het Plattelands Ontwikkelingsprogramma (POP3).

Het project Nutriëntenmaatregelen van de Kennisimpuls Waterkwaliteit ${ }^{31}$ richt zich op een gebiedsgerichte aanpak door eerst bronnen en routes van nutriëntenverliezen in beeld te brengen en vervolgens te bepalen welke maatregelen waar effectief zijn. Onderdeel van dit project is het deelproject 'Maatregelen op de kaart'. Om na te gaan op welke percelen welke maatregelen genomen kunnen worden, kan gebruik worden gemaakt van de webapplicatie Maatregel op kaart (Van Gerwen et al., 201932). De in het project 'Maatregel op de kaart' ontwikkelde methodiek omvat een eerste stap naar een gericht maatregelenadvies op perceelniveau om te komen tot schoner grond- en oppervlaktewater.

In een studie van CDM zijn op basis van expertkennis maatregelen geselecteerd waarvan de verwachting is dat deze, boven op de maatregelen van bestaand beleid, een substantiële daling van de stikstof- en fosfaatconcentraties in het oppervlaktewater tot gevolg kunnen hebben (Velthof et al., 2018). Samengevat gaat het over de volgende maatregelen:

- Gewasbeheer: voorjaarstoediening van mest op kleigrond in plaats van najaarstoediening, uitbreiding van het areaal met een vanggewas, geen mest toedienen op gescheurd grasland, afvoer van gewasresten en hergebruik van slootbagger als meststof.

- Bodembeheer: uitmijnen van bodemfosfaat in landbouwgronden, de teelt van maïs in stroken uitgefreesd in grasland en minimale grondbewerking.

- Hydrologische maatregelen: beperken van oppervlakkige afspoeling op het veld en verbeterde drainage om plasvorming te voorkomen.

- Technische maatregelen: het inrichten van reactieve barrières in en op de bodem van een landbouwperceel en fosforverwijdering uit het oppervlaktewater (waterzuivering).

- Ruimtelijke maatregelen: aanpassen van het bouwplan, beperking van beweiding, teelten uit de grond, grasbufferstroken en het saneren van hotspots van uit- en afspoeling.

Ook door verbeteringen in bemesting, zoals een juiste timing, kan de uit- en afspoeling van stikstof en fosfaat worden beperkt. Het verminderen van de stikstofbemesting op snijmaïs kan leiden tot minder nitraatuitspoeling met slechts een beperkte opbrengstderving.

De toepassing, de effectiviteit en de termijn waarop effecten op de waterkwaliteit zichtbaar zijn, zijn sterk afhankelijk van regionale omstandigheden. In sommige gebieden zijn geen aanvullende maatregelen nodig, terwijl in andere gebieden een groot aantal en soms vergaande maatregelen nodig zijn om de doelen te halen. Ook het realiseren van de beoogde ecologische doelstellingen uit de KRW is locatie-afhankelijk.

\subsubsection{Contouren nieuw mestbeleid}

In september 2020 heeft de minister van LNV de contouren van een nieuw mestbeleid gepresenteerd. ${ }^{33}$ Het voorgenomen beleid bestaat uit drie sporen: 1) grondgebondenheid (voor melk- en rundvleesveehouderijen; andere sectoren kunnen hiervoor kiezen), 2) afvoer en verwerking van mest voor niet-grondgebonden bedrijven en 3 ) gebiedsgerichte aanpak voor gebieden waar de waterkwaliteit achterblijft. De eerste twee sporen moeten leiden tot transparantere meststromen en tot mogelijkheden om fraude te beperken. Hierdoor zal het risico op overbemesting waarschijnlijk

\footnotetext{
${ }^{29}$ https://webapplicaties.wur.nl/Software/BedrijfsWaterWijzer/

${ }^{30}$ https://agrarischwaterbeheer.nl/document/boot-lijst-maatregelen-agrarisch-waterbeheer

${ }^{31}$ https://kennisimpulswaterkwaliteit.nl/nl

32 https://maatregelen-op-de-kaart.nmi-agro.nl/

33 https://www.rijksoverheid.nl/ministeries/ministerie-van-landbouw-natuur-envoedselkwaliteit/documenten/kamerstukken/2020/09/08/kamerbrief-contouren-toekomstig-mestbeleid
} 
verminderen en dat heeft een positieve invloed op de waterkwaliteit. Mogelijk dat boeren door mestverwerking en grondgebondenheid ook beter inzicht krijgen in de samenstelling en landbouwkundige werking van de mest, waardoor efficiënter bemest kan worden. Dit vraagt om voorlichting richting boeren. Er zijn echter nog veel vragen over de exacte invulling van deze sporen, zodat het uiteindelijke effect op nutriënten-gebruik en -uitspoeling op dit moment moeilijk is in te schatten.

Het derde spoor is gericht op een substantiële verbetering van de waterkwaliteit op basis van een gebiedsgerichte aanpak, met name in het zand- en lössgebied. In het Zevende Actieprogramma Nitraatrichtlijn moeten deze maatregelen worden opgenomen. In de brief over de contouren van een nieuw mestbeleid worden geen concrete maatregelen genoemd, maar er zullen ingrijpende maatregelen genomen moeten worden om de waterkwaliteit in met name het zuidelijke zandgebied te verbeteren (Figuur 36). Bij een gebiedsgerichte aanpak is ook aandacht nodig voor de governance. Het generieke spoor om nutriëntenuitspoeling te reguleren, loopt op dit moment via gebruiksnormen en -voorschriften in de Meststoffenwet en de Wet bodembescherming (Velthof et al., 2018). Regionale overheden kunnen alleen in specifieke situaties maatregelen nemen. Met de Omgevingswet nemen mogelijkheden om regionaal maatregelen te nemen toe. Er zou nader onderzoek moeten worden uitgevoerd om te bepalen of het wenselijk is om de mogelijkheden voor provincies en/of waterschappen uit te breiden om gebiedsgericht aanvullende maatregelen te nemen.

\subsubsection{Andere beleidsthema's}

Het klimaatbeleid zal een grote invloed hebben op de landbouw. Lesschen et al. (2020) hebben verschillende toekomstscenario's (2050) doorgerekend, waarbij er onderscheid werd gemaakt tussen productiviteit-gedreven en natuurinclusieve bedrijfsvoering. Voor beide typen werd daarnaast onderscheid gemaakt tussen voorgenomen beleid en strikter beleid. Voor waterkwaliteit werd bij voorgenomen beleid uitgegaan van reductie in uitspoeling van stikstof en fosfor met elk $12 \%$ en bij een strikter beleid met $17 \%$ op nationaal niveau. In dit strikte scenario werd ook een forse reductie van ammoniakemissie gerealiseerd en nam de broeikasgasemissie af tot een niveau waarbij er netto geen emissie meer optreedt. De mestvoerkringloop was gesloten binnen Europa. In de berekeningen wordt voldaan aan de reductie in uitspoeling op nationaal niveau in 2050 . Hieronder ligt een groot aantal (vaak technische) maatregelen, soms vergaand, zoals geen beweiding en gesloten stallen. Een van de belangrijkste factoren die tot een verbetering van de waterkwaliteit leidt in deze studie is de aanname dat in 2050 geen overbemesting plaatsvindt. Er wordt door Lesschen et al. (2020) aangegeven dat de fosfaatdoelstellingen in het oppervlaktewater mogelijk niet worden gehaald, omdat er na-ijling uit de bodem plaatsvindt. Hiermee is geen rekening gehouden in de berekeningen. De belangrijkste boodschap van dit rapport is dat met het nemen van een groot aantal, soms vergaande, maatregelen in de verschillende beleidsterreinen er in 2050 kan worden voldaan aan milieudoelstellingen voor klimaat, ammoniak en waterkwaliteit.

De Commissie Remkes concludeert in haar advies Niet alles kan overal: Eindadvies over structurele aanpak op lange termijn dat er een grondige modernisering van het Nederlandse Mestbeleid noodzakelijk is, waarbij ingezet wordt op kwalitatief hoogwaardige dierlijke mest en reductie van gebruik van kunstmest (Remkes et al., 2020). Ook adviseert deze commissie de introductie van een integraal instrumentarium om het nutriëntengebruik in de landbouw in balans te brengen: de Afrekenbare StoffenBalans. Dit instrumentarium lijkt op het oude MINAS-systeem en is gebaseerd op in- en outputsturing. De minister van landbouw heeft aangegeven te willen verkennen in hoeverre inen outputsturing bij kan dragen aan het oplossen van de stikstofproblematiek. ${ }^{34}$ Uit deze evaluatie moet ook blijken of de Afrekenbare StoffenBalans een instrument is waarmee waterkwaliteitsdoelstellingen sneller gerealiseerd kunnen worden dan het huidige stelstel gebaseerd op gebruiksnormen en middelvoorschriften.

\footnotetext{
${ }^{34}$ https://www.rijksoverheid.nl/ministeries/ministerie-van-landbouw-natuur-envoedselkwaliteit/documenten/kamerstukken/2020/09/08/kamerbrief-contouren-toekomstig-mestbeleid
} 


\subsection{Conclusies}

- De nitraatconcentratie in het water dat uitspoelt uit de wortelzone op landbouwbedrijven in de zand-, löss- en kleiregio's laat langjarig een dalende trend zien. In 2017 werd op alle grondsoorten gemiddeld voldaan aan de nitraatnorm van $50 \mathrm{mg}$ nitraat per $\mathrm{L}$, behalve in het zuidelijke zandgebied (gemiddeld $75 \mathrm{mg}$ nitraat per L). Op melkveebedrijven werd tot 2017 op alle grondsoorten gemiddeld voldaan aan de nitraatnorm van $50 \mathrm{mg}$ nitraat per L. De nitraatconcentratie op akkerbouwbedrijven op zandgrond laat een dalende trend zien, maar gemiddeld is de nitraatnorm nog niet gerealiseerd. De nitraatconcentraties zijn in 2018 en 2019 op alle grondsoorten sterk gestegen door extreme droogte, vaak boven de nitraatnorm.

- De stikstofconcentratie (zomergemiddelde) in zoete wateren laat een langjarig dalende trend zien. Net zoals in LMM, neemt in MNLSO de nitraatconcentratie toe na de droge zomer 2018.

- Mochten extreme droogte- en natte perioden in de toekomst vaker voorkomen door klimaatverandering, dan wordt het lastig om de effectiviteit van maatregelen op de waterkwaliteit te bepalen. De verwachte effecten van de maatregelen op waterkwaliteit zijn namelijk kleiner dan de grote, door droogte veroorzaakte fluctuaties in waterkwaliteit in recente jaren. In de monitoring van waterkwaliteit is altijd al sprake geweest van jaar-tot-jaarverschillen. In de monitoringsopzet en dataverwerking en -interpretatie van de resultaten moet daar rekening mee worden gehouden. Bij LMM wordt daarvoor een weercorrectie uitgevoerd (Boumans en Fraters, 2017). In MNLSO worden trendanalysemethoden toegepast die niet worden beïnvloed door jaar-tot-jaarschommelingen. Voor beide meetnetten geldt dat het gevaarlijk is om conclusies te trekken op basis van verschillen tussen individuele meetjaren.

- In het Vijfde Actieprogramma Nitraatrichtlijn zijn verschillende maatregelen genomen waarvan verwacht mag worden dat ze leiden tot minder uitspoeling van stikstof en fosfaat naar grond- en oppervlaktewater. Dit geldt met name voor de verlaging van de stikstofgebruiksnormen voor uitspoelingsgevoelige gewassen in het zuidelijke zand- en lössgebied en verlaging van de derogatie voor bemesting met graasdierenmest in de zandregio's zuid en midden en de lössregio. Op basis van resultaten van LMM lijken de maatregelen uit het Vijfde Actieprogramma tot een vermindering van de nitraatuitspoeling op akkerbouwbedrijven op zandgrond te hebben geleid in 2017, maar monitoring over een langere periode is nodig om hierover hardere uitspraken te doen.

- De effecten van de meeste maatregelen uit het Zesde Actieprogramma Nitraatrichtlijn zijn nog onduidelijk, omdat ze in 2020 en 2021 zijn/worden geïmplementeerd. Van de maatregelen die 1 januari 2019 zijn ingegaan, is een deel gericht op verruimingen in landbouwkundig handelen, maar niet op verbeteren van waterkwaliteit. De strengere eisen aan zaaien van het vanggewas na snijmaïs zullen waarschijnlijk de komende jaren tot een verlaging van de nitraatuitspoeling leiden. Van de andere maatregelen uit het Zesde Actieprogramma Nitraatrichtlijn wordt een beperkt effect verwacht op de landelijke gemiddelde nitraatconcentratie in het grondwater en onvoldoende om gebiedsgemiddeld ook in het zuidelijke zand- en lössgebied aan de nitraatnorm te voldoen.

- Er zijn de laatste tien jaar geen grote veranderingen in arealen van gewassen opgetreden die tot veranderingen in waterkwaliteit kunnen hebben geleid. De opbrengsten van akkerbouwgewassen fluctueren de laatste jaren door effecten van droogte, na een stijgende trend gedurende een periode van meer dan tien jaar. Veranderingen in opbrengsten bij gelijkblijvende bemesting leiden tot veranderingen in stikstof- en fosfaatoverschotten en daarmee tot veranderingen in het risico op stikstof- en fosforuitspoeling.

- Berekeningen op basis van de gebruiksruimte van stikstof en fosfaat en de export van mest geven aan dat er in Nederland overbemesting optreedt. De onzekerheden in de berekening van mestplaatsing zijn echter groot en het is niet duidelijk op welke schaal en waar overbemesting plaatsvindt. Overbemesting vergroot het stikstof- en fosfaatoverschot en kan daardoor mogelijk mede een oorzaak zijn van een verslechtering van de waterkwaliteit.

- Bodemverdichting komt op grote schaal voor in Nederland en heeft waarschijnlijk een effect op de uitspoeling van stikstof en fosfaat naar grond- en oppervlaktewater. Het is echter niet bekend welke rol bodemverdichting speelt bij de belasting van grond- en oppervlaktewater met nutriënten en of hier de laatste tien jaar veranderingen in zijn optreden. De langjarige trend in het gehalte aan organische stof in landbouwgronden is stabiel tot licht stijgend en er is geen reden om aan te nemen dat het gehalte aan organische stof heeft geleid tot veranderingen in waterkwaliteit. Er is ook geen aanleiding om te veronderstellen dat veranderingen in bodembiodiversiteit gedurende de laatste tien jaar hebben geleid tot veranderingen in waterkwaliteit. 
- Het is niet te verwachten dat (na-ijling van) de maatregelen uit het Vijfde en Zesde Actieprogramma en de maatregelen uit DAW tot realisatie van de waterkwaliteitsdoelstellingen zullen leiden. Om de doelen te kunnen halen, zijn voor een deel van de wateren, waaronder delen van het Maasstroomgebied, verdergaande structurele maatregelen nodig. Het realiseren van de doelstellingen uit de 'Bestuursovereenkomst aanvullende aanpak nitraatuitspoeling uit agrarische bedrijfsvoering in specifieke grondwaterbeschermingsgebieden' zal zeer lastig zijn. Naast strikte maatregelen op het gebied van nutriëntenbeheer op bedrijven zullen andersoortige maatregelen moeten worden genomen.

- Er zijn verschillende maatregelen op het gebied van gewasbeheer, bemesting, bodembeheer, hydrologie, technische maatregelen en ruimtelijke maatregelen die tot een verbetering van de waterkwaliteit kunnen leiden. De toepassing, de effectiviteit en de termijn waarop effecten van maatregelen op de waterkwaliteit zichtbaar zijn, zijn sterk afhankelijk van regionale omstandigheden.

- De herziening van het mestbeleid en de maatregelen in het kader van het ammoniak- en klimaatbeleid zullen in de toekomst een effect hebben op nutriëntenuitspoeling uit landbouwgronden. De invulling van dit beleid is op dit moment echter nog onduidelijk; dit zal in de komende jaren plaatsvinden. Daarom wordt verwacht dat de herziening van het mestbeleid en de maatregelen in het kader van het ammoniak- en klimaatbeleid geen grote bijdrage zullen leveren aan het realiseren van waterkwaliteitsdoelstellingen gedurende het Zevende Actieprogramma Nitraatrichtlijn (2022-2026) en de derde generatie stroomgebiedbeheerplannen van de Kaderrichtlijn Water (2021-2027). 


\section{Literatuur}

Akker, J.J.H. van den, R.F.A. Hendriks (2015) Hoe erg is ondergrondverdichting in de landbouw? Een samenvatting en conclusies uit onderzoek naar ondergrondverdichting. Bodem 3-2015, blz 42-44.

Akker, J.J.H. van den (2019) Bodemverdichting: ondergrond en bovengrond. Fact finding paper in opdracht van de Raad voor de leefomgeving en infrastructuur.

https://www.rli.nl/sites/default/files/fact_finding_paper_4_bodemverdichting_ondergrond_en_bov engrond_-_jan_van_den_akker_wur.pdf

Bannink A., H. Bayissa \& J. Dijkstra J. (2015) Oogstmoment snijmaïs beïnvloedt methaanuitstoot, Veeteelt, oktober 2015, p34-35.

Beltman, W., J. Boesten, G.J. Reinds, A. Reijneveld, R. Rietra, P. Römkens \& G. Velthof (2019). Chemische Bodemkwaliteit in Nederland. Fact finding paper in opdracht van de Raad voor de leefomgeving en infrastructuur. Wageningen Environmental Research. https://www.rli.nl/sites/default/files/factfi2.pdf

Bikker, P., L.B. Šebek, C. van Bruggen \& O. Oenema (2019). Stikstof- en fosfaatexcretie van gangbaar en biologisch gehouden landbouwhuisdieren. Herziening excretieforfaits Meststoffenwet 2019. Wettelijke Onderzoekstaken Natuur \& Milieu, WUR, Wageningen. WOt-technical report 152. 87 blz.

Birch, H.F. (1964) Mineralisation of plant nitrogen following alternate wet and dry conditions. Plant Soil 20: 43- 49.

Booltink, H.W.G. (2015) Field monitoring of nitrate leaching and water flow in a structured clay soil. Agriculture, Ecosystems \& Environment. Volume 52, Pages 251-261.

Boumans, L.J.M. B. Fraters, B. (2017) Actualisering van de trendmodellering van gemeten nitraatconcentraties bij landbouwbedrijven. Landelijk Meetnet effecten Mestbeleid. Rijksinstituut voor Volksgezondheid en Milieu, Bilthoven, RIVM. Rapport 2016-0211.

Brink, C. van den, A. Struik, \& J. Jaap Pape (2020) Verkenning effectiviteit van verschillende vormen van agrarische bedrijfsvoering in het kader van de Bestuursovereenkomst 'Aanvullende aanpak nitraatuitspoeling uit agrarische bedrijfsvoering in specifieke grondwaterbeschermingsgebieden', Royal HaskoningDHV BH2977WATRP2006091139WM

Broers, H.P., J. Griffioen, W.J. Willems \& B. Fraters. (2004a). Naar een andere toetsdiepte voor nitraat in grondwater? Achtergronddocument voor de Evaluatie Meststoffenwet 2004, Nederlands Instituut voor Toegepaste Geowetenschappen. Utrecht: TNO-Rapport NITG 04-066-A.

Broers, H.P. \& B van der Grift (2004) Regional monitoring of temporal changes in groundwater quality. Journal of Hydrology 296 (1-4), 192-220.

Bruggen, C. van \& K. Geertjes (2019) Stikstofverlies uit opgeslagen mest - Stikstofverlies berekend uit het verschil in verhouding tussen stikstof en fosfaat bij excretie en bij mestafvoer. Centraal Bureau voor de Statistiek, Den Haag/Heerlen/Bonaire, 2019.

Brus. D.J. \& J.J.H. Van den Akker (2018). How serious a problem is soil compaction in the Netherlands? A survey based on probability sampling. SOIL, 4, 37-45, 2018.

Buijs, S. (2020) Update toestand en trend MNLSO tot en met 2019. Deltares memo 11205268-005BGS-0001. 11 november 2020.

Buijs, S., K. Ouwerkerk \& J. Rozemeijer (2020) Meetnet Nutriënten Landbouw Specifiek Oppervlaktewater. Toestand en trends tot en met 2018. Deltares rapport 11203728-005-BGS0002.

CDM (2013) CDM-advies 'Beoordeling mestproductie op basis van het Protocol Gebruiksvoorschriften Dierlijke Mest versie $1.0^{\prime}$

CDM (2016) Nitraatbepaling in bodemvocht in lössgronden, Advies Commissie Deskundigen Meststoffenwet 14/N\&M0175.

CDM (2017a) 'Advies beoordeling emissiereductie alternatieve mesttoedieningstechnieken Commissie Deskundigen Meststoffenwet'

CDM (2017b) CDM-Advies 'Groenbemesters'

CDM (2017c) CDM-advies 'Relatie organische stofgehalte in de bodem en nitraatuitspoeling'

CDM (2017d). Advies 'Beperking nitraatuitspoeling bij scheuren en herinzaai van grasland'

CDM (2017e) CDM-advies 'Effecten van rijenbemesting bij maïsgewassen op nitraatuitspoeling' 
CDM (2019a) CDM-advies 'Analyse boetes bij overtreding Meststoffenwet'

CDM (2019b) CDM-advies 'Verzoek om advies invulling gecombineerde indicator fosfaattoestanden bodem'

CDM (2020a) CDM-advies: 'Structureel omgaan met droogte'.

CDM (2020b) CDM-advies: 'Milieueffecten bij geen derogatie van de Nitraatrichtlijn'

CDM (2020c) CDM-advies: 'Bouwplan en nitraatuitspoeling'.

CDM (2020d) CDM-advies: 'Analyse van ontwikkelingen in ammoniakemissie uit de landbouw in de periode 2012-2018'.

CDM (2020e) CDM-advies 'Stikstofverliezen uit mest in stallen en mestopslagen'.

CDM (2020f) CDM-advies 'Hoe om te gaan met gebruiksregels bij droogte in 2020'

CDM (2020g) CDM-advies 'Structureel omgaan met droogte in het mestbeleid'

CDM (2020h) CDM-advies 'Verkennende analyse van het stelsel van stikstofgebruiksnormen'

CDM (2020i) CDM-advies 'Effecten van mesttoediening op regenwormen als voedsel voor weidevogels'

Claessens J.M., N.G.F.M. Van der Aa, P. Groenendijk \& L. Renaud (2017). Effecten van het landelijk mestbeleid op de grondwaterkwaliteit in grondwaterbeschermingsgebieden. RIVM Bilthoven. Rapportnummer 2016- 0199

Corré W.J., C.L. Van Beek CL, \& J.W. Van Groenigen (2014) Nitrate leaching and apparent recovery of urine- $\mathrm{N}$ in grassland on sandy soils in the Netherlands. NJAS -Wageningen. Journal of Life Sciences 70, 25-32.

Dekker, L.W. (1998) Moisture variability resulting from water repellency in Dutch soils. Doctoral thesis, Wageningen Agricultural University, The Netherlands, 240 pp.

Dijk, W. \& J.J. Schröder (2007) Adviezen voor stikstofgebruiksnormen voor akker- en tuinbouwgewassen op zand- en lössgronden bij verschillende uitgangspunten. PPO-rapport 371.

NCM (2019) Landelijke rapportage en inventarisatie export en verwerking dierlijke mest, Nederlands Centrum voor Mestverwaarding.

Ehlert, P.A.I. \& P. de Willigen (1999) Relatie fosfaatbehoefte vollegrondsgroenten en fosfaattoestand in de bodem. In: Dekker. P.H.M. In: Naar maatwerk in bemesting. Themaboekje 22, Praktijkonderzoek voor de Akkerbouw en de Vollegrondsgroenteteelt, p. $32-43$.

EU (1991) Richtlijn 91/676/EEC van de Raad van 12 december 1991 inzake de bescherming van water tegen verontreiniging door nitraten uit agrarische bronnen. Publicatieblad van de Europese Gemeenschappen, nr. L375:1-8.

EU (2000) Richtlijn 2000/60/EG van het Europees Parlement en de Raad van 23 oktober 2000 tot vaststelling van een kader voor communautaire maatregelen betreffende het waterbeleid. OJ L 327, 22.12.2000, p. 1-73.

Evers, C.H.M., A.J.M. van den Broek, R. Buskens, A. van Leerdam, R.A.E. Knoben, \& F.C.J. van Herpen (2012). Omschrijving MEP en maatlatten voor sloten en kanalen voor de Kaderrichtlijn Water 2015-2021. STOWA rapportnummer 2012-34.

Fraters, B., A.E.J. Hooijboer, A. Vrijhoef, A.C.C. Plette, N. Van Duijnhoven, J.C. Rozemeijer, M. Gosseling, C.H.G. Daatselaar, J.L. Roskam \& H.A.L. Begeman (2020) Landbouwpraktijk en waterkwaliteit in Nederland; toestand (2016-2019) en trend (1992-2019). De Nitraatrapportage 2020 met de resultaten van de monitoring van de effecten van de EU Nitraatrichtlijn actieprogramma's. Rijksinstituut voor Volksgezondheid en Milieu, Bilthoven, RIVM rapport 20200121.

Fraters, B. \& T. van Leeuwen (2018) Actualiseren uitspoelfracties t.b.v. project 'Nitraatwijzer'. Interne Notitie MIL-BW-N-18-25, RIVM, Bilthoven.

Gaalen, van, F., L. Osté, \& E. van Boekel (2020) Nationale analyse waterkwaliteit. Onderdeel van de Delta-aanpak Waterkwaliteit. Eindrapport. Den Haag, Planbureau voor de Leefomgeving, PBLpublicatienummer: 4002

Gerven, L. van, S. Jansen \& P. Groenendijk (2019) Maatregel op de Kaart (Fase 1). Identificeren van kansrijke landbouwmaatregelen per perceel voor schoner grond- en oppervlaktewater. Kennisimpuls Waterkwaliteit https://www.kennisimpulswaterkwaliteit.nl/sites/default/files/201911/KIWK-Notitie\%20Maatregel\%20op\%20de\%20Kaart.pdf

Groenendijk, P., E. van Boekel, L. Renaud, A. Greijdanus, R. Michels \& T. de Koeijer (2016) Het aandeel van landbouw in de KRW-opgave voor nutriënten in regionale wateren en effecten van maatregelen. Vermindering van de uit- en afspoeling en kosten van maatregelen. Wageningen, Wageningen Environmental Research, rapport 2749. 
Groenendijk, P., J.H.M. Wosten, R. Postma, \& R. Ruijtenberg (2019). Organische stof: de moeite waard voor waterbeheer? Water Matters: Kenniskatern voor Waterprofessionals - Dutch edition, 28-31.

Groenendijk, P., G.L. Velthof, J.J. Schröder, T.J. de Koeijer \& H.H. Luesink (2017) Milieueffectrapportage van maatregelen zesde Actieprogramma Nitraatrichtlijn; Op Planniveau. Wageningen, Wageningen Environmental Research, Rapport 2842.

Groenendijk, P., L. van Gerven \& E. van Boekel (2020). Maatregelen in het landelijk gebied ter vermindering van nutriëntengehalten in het oppervlaktewater; Achtergrondinformatie over maatregelen ten behoeve van de Nationale Analyse Waterkwaliteit. Wageningen Environmental Research, Rapport Kennis Impuls Waterkwaliteit en Zoetwater.

Groenestein, K., N. Ogink, H. Ellen, L. Šebek, C. van Bruggen, J. Huijsmans, \& I. Vermeij (2019). PAS Update aanvullende reservemaatregelen Landbouw. (Rapport / Wageningen Livestock Research; No. 1214). Wageningen Livestock Research. https://doi.org/10.18174/507036

Hoogeveen, M., C. Daatselaar \& H. Prins (2019) Afname derogatie: verkenning omvang en beweegredenen ondernemers. WECR notitie.

https://www.rijksoverheid.nl/documenten/rapporten/2019/07/19/afname-derogatie-verkenningomvang-en-beweegredenen-ondernemers

Hooijboer, A.E.J., M. Hoogsteen, \& E. Buis (2017) Abstract number-234 Effects of crop rotation on water quality in the Netherlands: Combining the Minerals Policy Monitoring Programme and Nationwide survey of crop data of the sandy regions of the Netherlands. LuWQ2017, Land Use and Water Quality: Effect of Agriculture on the Environment The Hague, the Netherlands, 29 May 1 June 2017.

Klages, S., C. Claudia, \& B. Bernhard (2020) The Impact of Agricultural Production and Policy on Water Quality during the Dry Year 2018, a Case Study from Germany, Water 6, 1519.

Klootwijk, C.W., \& H.A. van Schooten (2020) Effect van ruitzaai en drijfmestrijenbemesting op de stikstofbenutting van snijmaïsteelt. Wageningen Livestock Research, Rapport 1256.

Koeijer, T.J. de, C.C. de Lauwere, H.H. Luesink \& H. Prins (2018) Handelsverkeer in de mestmarkt: opties voor interventies. Wageningen, Wageningen Economic Research, Rapport 2018-057. 54 blz.

Koopmans, C. en M. van Opheusden (2019) Organische stof in de Nederlandse bodem. Feiten en discussie in perspectief. Fact finding paper in opdracht van de Raad voor de leefomgeving en infrastructuur. Louis Bolk Instituut.

https://www.rli.nl/sites/default/files/fact_finding_paper_3_organische_stof_in_de_nederlandse_bo dem_-_chris_koopmans_en_mieke_van_opheusden_louis_bolk_instituut.pdf

Kros, H., J. van Os, J.C. Voogd, P. Groenendijk, C. van Bruggen, R. te Molder, \& G. Ros (2019). Ruimtelijke allocatie van mesttoediening en ammoniakemissie: beschrijving mestverdelingsmodule INITIATOR versie 5. (Wageningen Environmental Research rapport; No. 2939). Wageningen Environmental Research.

Lagerwerf, L.A., A. Bannink, C. van Bruggen, C.M. Groenestein, J.F.M. Huijsmans, J.W.H. van der Kolk, H.H. Luesink, S.M. van der Sluis, G.L. Velthof \& J. Vonk (2019). Methodology for estimating emissions from agriculture in the Netherlands. Calculations of $\mathrm{CH} 4, \mathrm{NH} 3, \mathrm{~N} 2 \mathrm{O}$, NOx, NMVOC, PM10, PM2.5 and CO2 with the National Emission Model for Agriculture (NEMA) - update 2019. Wageningen, The Statutory Research Tasks Unit for Nature and the Environment. WOttechnical report $148.215 \mathrm{p}$

LBO (2020) Landelijk Bestuurlijk Overleg Nitraat in grondwaterbeschermingsgebieden. Vergadering 29 juni 2020. Betreft: Besluit van het LBO inzake afspraak 7c van de Bestuursovereenkomst.

Lesschen, J.P., J.W. Reijs, T.V. Vellinga, J. Verhagen, H. Kros, M. de Vries, R.A. Jongeneel, T. Slier, A. Gonzalez Martinez, I. Vermeij, \& C.H.G. Daatselaar (2020). Landbouw in Nederland in 2050: Effecten van ontwikkelrichtingen. Wageningen Environmental Research

LTO (2019) Jaarverslag Deltaplan Agrarisch Waterbeheer 2019. https://agrarischwaterbeheer.nl/system/files/documenten/pagina/daw_jaarverslag2020_Ir.pdf

Lukács S., P.W. Blokland, R. van Duijnen, D. Fraters, G.J. Doornewaard \& C.H.G Daatselaar (2020) Landbouwpraktijk en waterkwaliteit op landbouwbedrijven aangemeld voor derogatie in 2018. RIVM rapport 2020-0096, $116 \mathrm{p}$.

Middelkoop J.C. \& G. Holshof (2017) Nitrogen Fertilizer Replacement Value of Concentrated Liquid Fraction of Separated Pig Slurry Applied to Grassland, Communications in Soil Science and Plant Analysis, 48:10, 1132-1144. 
Ministerie van LNV (2017) Zesde Nederlandse actieprogramma betreffende de Nitraatrichtlijn (2018 2021).

Ministerie van LNV (2020) Betreft Voortgang verlenging derogatie en diverse dossiers mestbeleid. 18 mei 2020. Kenmerk DGA-PAV / 20018773.

Molen, van der D.T., R. Pot, C.H.M. Evers, L.L.J. van Nieuwerburgh (2012) Referenties en maatlatten voor natuurlijke watertypen voor de Kaderrichtlijn Water 2015-2021. STOWA rapportnummer 2012-31.

Munch, J.C. \& Velthof, G.L. (2007) Denitrification and agriculture. In: Biology of the Nitrogen. Cycle. Bothe, H, Ferguson, SJ, Newton, WE, Amsterdam: Elsevier, - p. 331 - 341.

Raad voor de Leefomgeving en infrastructuur (RLi) (2020) De Bodem Bereikt? 6 juni 2020

Remkes, J.W., J.J. van Dijk, E. Dijkgraaf, A. Freriks, G.J. Gerbrandy, W.H. Maij, A.G. Nijhof, E. Post, R. Rabbinge, M.C.T. Scholten, \& L.E.M. Vet (2020). Niet alles kan overal: Eindadvies over structurele aanpak op lange termijn. Adviescollege Stikstofproblematiek.

Rijksoverheid (2016a) Meststoffenwet - Geldend vanaf 01-03-2016 t/m heden. Overheid.nl, http://wetten.overheid.nl/BWBR0004054/2016-03-01.

Rijksoverheid (2016b) Uitvoeringsregeling Meststoffenwet - Geldend van 01-01-2016 t/m heden. Overheid.nl. http://wetten.overheid.nl/BWBR0018989/2016-01-01.

Ros, G.H., H. Kros \& J. de Pater (2019) Mestbewerking en Waterkwaliteit een case studie voor het beheergebied van waterschap Aa en Maas. De samenvatting. NMI Report 1695.N.17.

Rozemeijer, J.C. \& H.P. Broers (2007) The groundwater contribution to surface water contamination in a region with intensive agricultural land use (Noord-Brabant, The Netherlands). Environmental Pollution 148 (3), 695-706.

Rozemeijer, J.C., Y. Van der Velde, F.C. Van Geer, G.H. De Rooij \& P.J.J.F. Torfs (2010) Improving load estimates for NO3 and P in surface waters by characterizing the concentration response to rainfall events. Environmental science \& technology 44 (16), 6305-6312.

Rozemeijer, J.C., J. Klein, H.P. Broers, T.P. van Tol-Leenders \& B. van der Grift (2014) Water quality status and trends in agriculture-dominated headwaters; a national monitoring network for assessing the effectiveness of national and European manure legislation in The Netherlands. Environmental monitoring and assessment, 186(12), 8981-8995.

Rutgers, M., A. Orgiazzi, C. Gardi, J. Römbke, S. Jänsch, A.M. Keith, R. Neilson, B. Boag, O. Schmidt, A.K. Murchie, R.P. Blackshaw, G. Pérès, D. Cluzeau, M. Guernion, M.J.I. Briones, J. Rodeiro, R. Piñeiro, D.J.D. Cosín, J.P. Sousa, M. Suhadolc, I. Kos, P.H. Krogh, J.H. Faber, C. Mulder, J.J. Bogte, H.J. van Wijnen, A.J. Schouten en D. de Zwart (2016) Mapping earthworm communities in Europe. Appl. Soil Ecol. 97: 98-111.

Rutgers, M., J.P. van Leeuwen, D. Vrebos, H.J. van Wijnen, T. Schouten, R.G.M. de Goede (2019) Mapping Soil Biodiversity in Europe and the Netherlands. Soil Syst. 3, 39.

Schils, R., R. Geerts, J. Oenema, K. Verloop, F. Assinck en G.L. Velthof (2014) Effect van bemesting met mineralenconcentraat op het nitraatgehalte van grondwater. Verkennend onderzoek in het kader van de Pilot Mineralenconcentraten. Alterra report 2570, Wageningen.

Schoumans, O. F. (2015). Phosphorus leaching from soils: process description, risk assessment and mitigation. Wageningen University. PhD thesis Wageningen University.

Schoumans, O. F., Schröder, J. J., Groenendijk, P., de Koeijer, T. J., Renaud, L. V., Lusink, M., \& Kruseman, G. (2013). Beknopte milieueffectrapportage op planniveau: in het kader van het Vijfde Actieprogramma Nitraatrichtlijn. (Alterra-rapport; No. 2461). Alterra, Wageningen-UR.

Schröder, J. J., \& van Dijk, W. (2019). Stikstofwerking van organische meststoffen en hun relatie met gebruiksnormen. (Wageningen Plant Research rapport; No. WPR-916). Stichting Wageningen Research, Wageningen Plant Research, Business unit Agrosysteemkunde.

Schröder, J.J., de Visser, W., Assinck, F.B.T. and Velthof, G.L. (2013), Effects of short-term nitrogen supply from livestock manures and cover crops on silage maize production and nitrate leaching. Soil Use Manage, 29: 151-160.

Schröder, J.J.; Dijk, van W.; Groot, de W.J.M. (1996) Effects of cover crops on the nitrogen fluxes in a silage maize production system. Netherlands Journal of Agricultural Science 44, $293-315$.

Schröder, J.J., H.F.M. Aarts, J.C. van Middelkoop, R.L.M. Schils, G.L. Velthof, B. Fraters en W.J. Willems (2007) Permissible manure and fertilizer use in dairy farming systems on sandy soils in The Netherlands to comply with the Nitrates Directive target. European Journal of Agronomy 27, 102-114. 
Schröder, J.J., F.B.T. Assinck, D. Uenk and G. L. Velthof (2009) Nitrate leaching from cut grassland as affected by the substitution of slurry with nitrogen mineral fertilizer on two soil types. Grass and Forage Science, 65, 49-57.

Schröder, J.J.; Visser, de W.; Assinck, F.B.T.; Velthof, G.L. (2013) Effects of short-term nitrogen supply from livestock manures and cover crops on silage maize production and nitrate leaching. Soil Use and Management 29, $151-160$.

Schroder, J.J.; Vermeulen, G.D.; Schoot, J.R. v.d.; Dijk, W. v.; Huijsmans, J.F.M.; Meuffels, G.J.H.M.; Schans, D.A. v.d. (2015) Maize yields benefit from injected manure positioned in bands. European Journal of Agronomy 64, 29-36.

Timmerman, A., D. Bos, J. Ouwehand, \& R.G.M. de Goede (2006) Long-term effects of fertilisation regime on earthworm abundance in a semi-natural grassland area. Pedobiologia (Jena) 50 : 427-432.

Tol-Leenders, van D., M. Knotters, W. de Groot, P. Gerritsen, A. Reijneveld, F. van Egmond, H. Wösten \& P. Kuikman (2019) Koolstofvoorraad in de bodem van Nederland (1998-2018): CCNL. Wageningen Environmental Research rapport; No. 2974.

Van der Sluis, S.M. (2017) Overbenutting van de plaatsingsruimte van dierlijke mest in het Zuidelijk Veehouderijgebied. Analyse van onzekerheden en mogelijke gevolgen voor de nitraatconcentratie in het bovenste grondwater. Den Haag: PBL.

Stachelek, T. Wagner \& P.A. Soranno (2019) Winter precipitation and summer temperature predict lake water quality at macroscales Water Resour. Res., 55 (2019), pp. 2708-2721.

Van der Putten, W. (2019) Bodembiodiversiteit in Nederlandse landbouw, bos en (droge) natuur. Pact finding paper voor de Raad voor Leefomgeving en Infrastructuur (RLI) voor het advies Vitale. Bodem, onderwerp Bodembiodiversiteit. Nederlands Instituut voor Ecologie (NIOO-KNAW).

Velthof, G.L. (2003) Relaties tussen mineralisatie, denitrificatie en indicatoren voor bodemkwaliteit in landbouwgronden. Wageningen: Alterra, Sturen op Nitraat rapport 6 / Alterra-rapport 769.

Velthof, G.L., T. Koeijer, J.J. Schröder, M. Timmerman, A. Hooijboer, J. Rozemeijer, C. van Bruggen \& P. Groenendijk (2017) Effecten van het mestbeleid op landbouw en milieu. Beantwoording van de ex-postvragen in het kader van de evaluatie van de Meststoffenwet. Wageningen, Wageningen Environmental Research, Rapport 2782.

Velthof, G.L., F.H. Kistenkas, P. Groenendijk, E.M.P.M. van Boekel \& O. Oenema (2018). Wettelijk instrumentarium voor landbouwmaatregelen om waterkwaliteit te verbeteren. Realisatie van nutriëntendoelstellingen uit de Kaderrichtlijn Water. Wageningen, WOT Natuur \& Milieu, WUR. WOt-rapport 129. $118 \mathrm{blz}$

Verloop, K., M. van Agtmaal, W. Bussink, N. van Eekeren, P. Groenendijk, S. Jansen, G.J. Noij \& M. Zanen (2018). Achtergronden bij informatie in de BOOT-lijst factsheets. (Rapport WPR; No. 842). Stichting Wageningen Research, Wageningen Plant Research, Business unit Agrosysteemkunde. 
Wageningen Environmental Research Postbus 47

6700 AA Wageningen

T 0317480700

www.wur.nl/environmental-research

Wageningen Environmental Research Rapport 3070

ISSN 1566-7197
De missie van Wageningen University \& Research is 'To explore the potential of nature to improve the quality of life'. Binnen Wageningen University \& Research bundelen Wageningen University en gespecialiseerde onderzoeksinstituten van Stichting Wageningen Research hun krachten om bij te dragen aan de oplossing van belangrijke vragen in het domein van gezonde voeding en leefomgeving. Met ongeveer 30 vestigingen, 6.500 medewerkers ( $5.500 \mathrm{fte}$ ) en 12.500 studenten behoort Wageningen University \& Research wereldwijd tot de aansprekende kennisinstellingen binnen haar domein. De integrale benadering van de vraagstukken en de samenwerking tussen verschillende disciplines vormen het hart van de unieke Wageningen aanpak. 


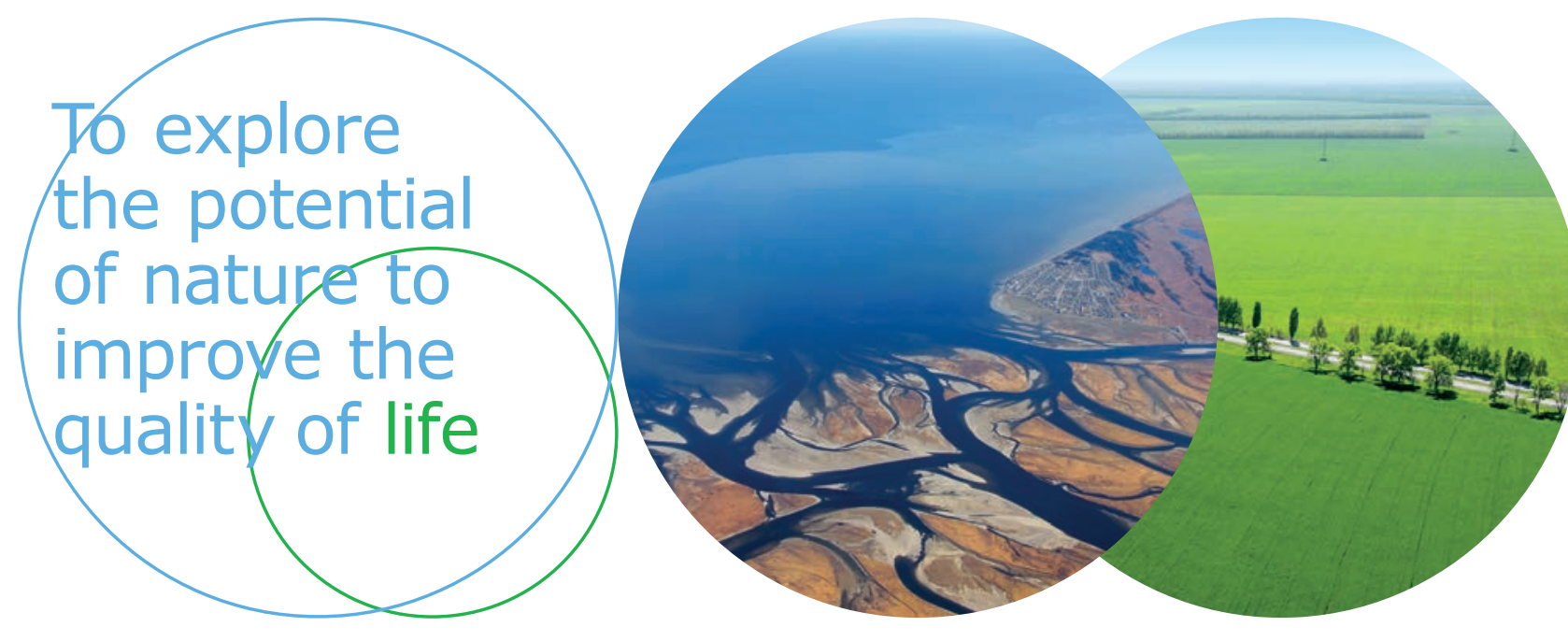

Wageningen Environmental Research Postbus 47

$6700 \mathrm{AB}$ Wageningen

T 317480700

www.wur.nl/environmental-research

Rapport 3070

ISSN 1566-7197
De missie van Wageningen University \& Research is 'To explore the potential of nature to improve the quality of life'. Binnen Wageningen University \& Research bundelen Wageningen University en gespecialiseerde onderzoeksinstituten van Stichting Wageningen Research hun krachten om bij te dragen aan de oplossing van belangrijke vragen in het domein van gezonde voeding en leefomgeving. Met ongeveer 30 vestigingen, 6.500 medewerkers ( $5.000 \mathrm{fte}$ ) en 12.500 studenten behoort Wageningen University \& Research wereldwijd tot de aansprekende kennisinstellingen binnen haar domein. De integrale benadering van de vraagstukken en de samenwerking tussen verschillende disciplines vormen het hart van de unieke Wageningen aanpak. 